\title{
Composición y diversidad funcional de plantas leñosas mediterzáneas: desde la hoja a la comunidad
}

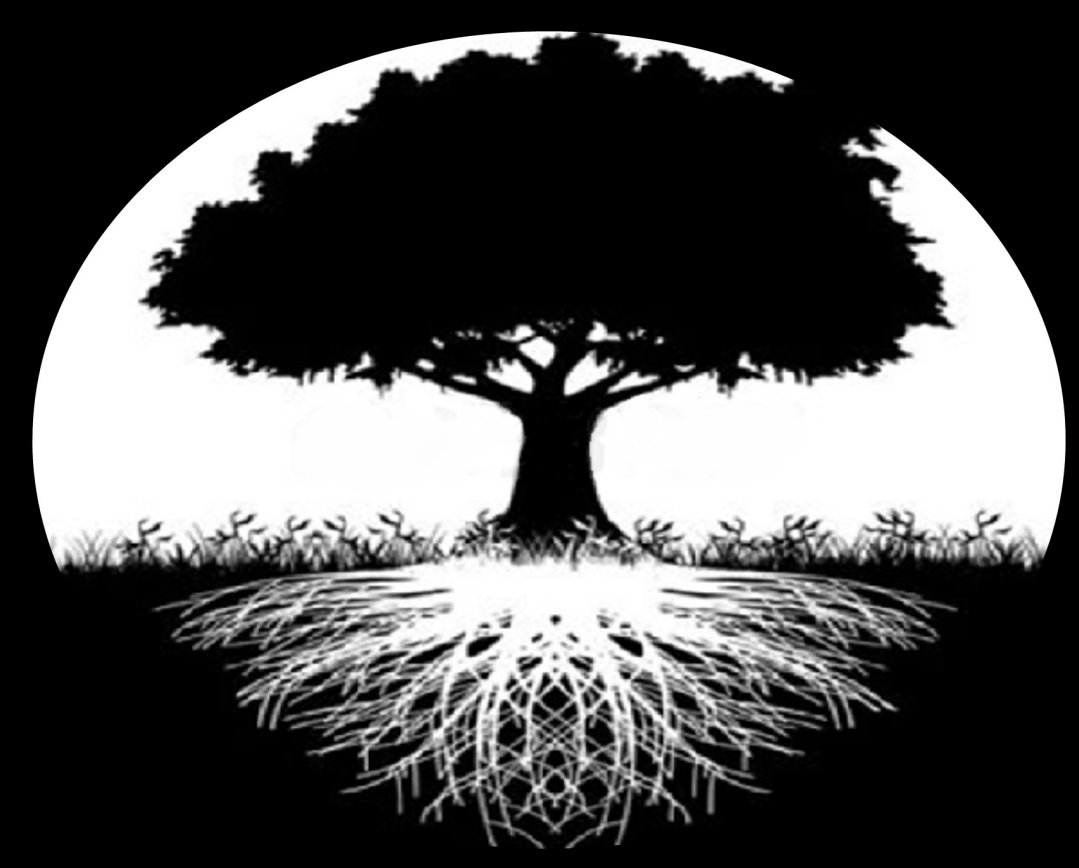

Jesis doctoral

Enrique garcia de la oRiva
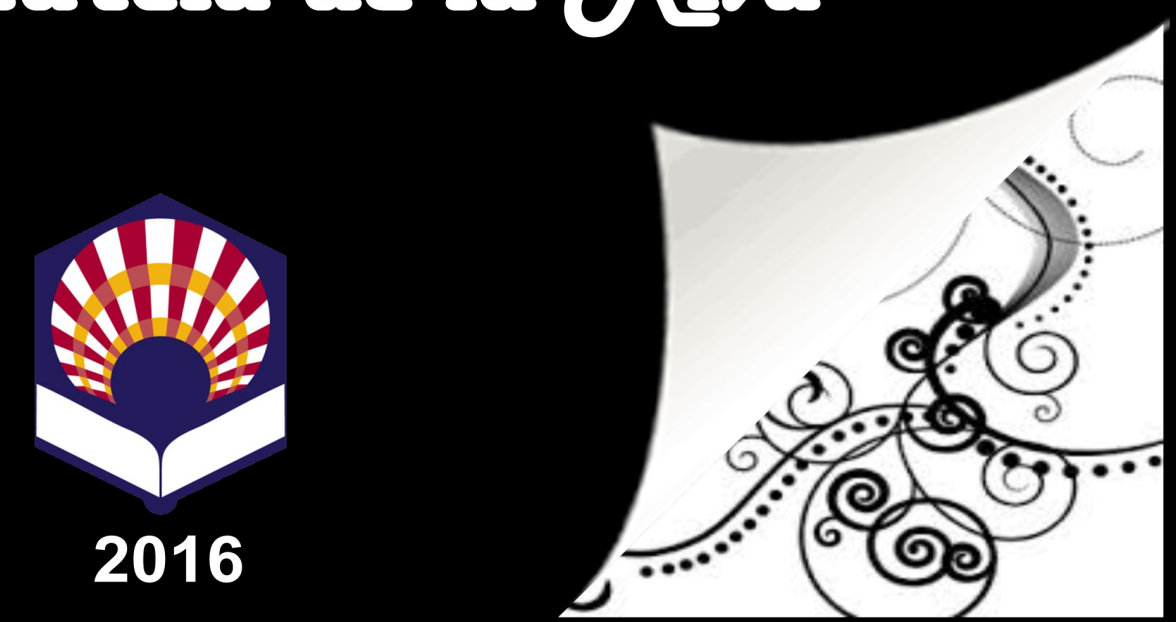
TITULO: Composición y diversidad funcional de plantas leñosas mediterráneas: desde la hoja a la comunidad.

AUTOR: Enrique García de la Riva

(c) Edita: Servicio de Publicaciones de la Universidad de Córdoba. 2016 Campus de Rabanales

Ctra. Nacional IV, Km. 396 A

14071 Córdoba

www.uco.es/publicaciones

publicaciones@uco.es 


\section{celA3}
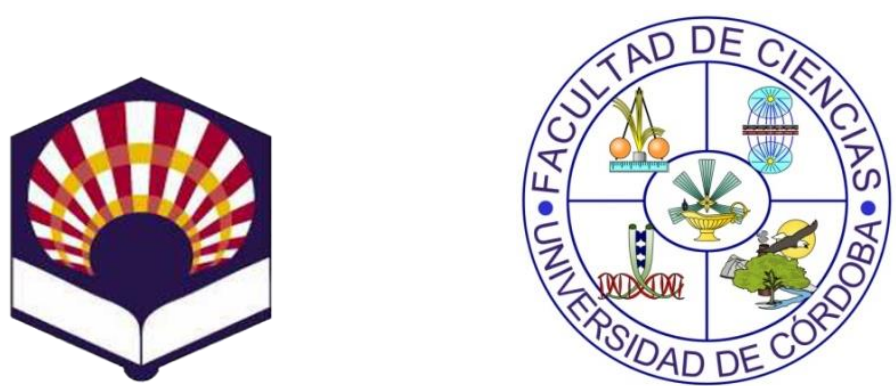

UNIVERSIDAD E CORDOBA

DEPARTAMENTO DE BOTÁNICA, ECOLOGÍA Y FISIOLOGÍA

VEGETAL

UNIVERSIDAD DE CÓRDOBA

TESIS DOCTORAL

Composición y diversidad funcional de plantas leñosas mediterráneas: desde la hoja a la comunidad

Enrique García de la Riva

Directores: Rafael Villar Montero, Ignacio Manuel Pérez Ramos

y Teodoro Marañón Arana

Córdoba, 15 Marzo de 2016 


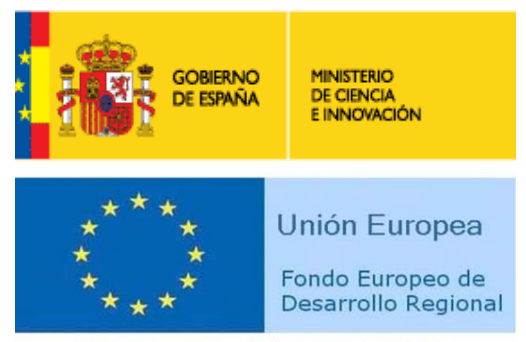

"Una manera de hacer Europa"

El presente trabajo se ha realizado en el marco de los Proyectos de Investigación DIVERBOS (CGL2011-30285-C02-01 and C02-02) titulado "Diversidad funcional $\boldsymbol{y}$ resiliencia del bosque mediterráneo" y ECO-MEDIT (CGL2014-53236-R) titulado "EI funcionamiento de los bosques mediterráneos desde la perspectiva del análisis económico de la producción" financiado por el Ministerio de Economía y Competitividad y fondos FEDER (Fondo Europeo de Desarrollo Regional, una manera de hacer Europa). 



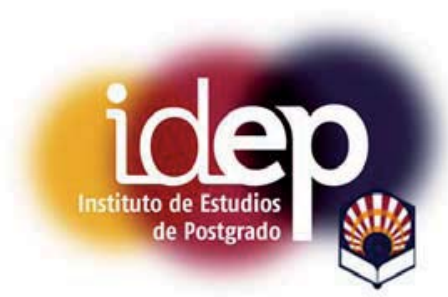

TÍTULO DE LA TESIS: Composición y diversidad funcional de plantas leñosas mediterráneas: desde la hoja a la comunidad

DOCTORANDO: Enrique García de la Riva

INFORME RAZONADO DEL/DE LOS DIRECTOR/ES DE LA TESIS

(se hará mención a la evolución y desarrollo de la tesis, así como a trabajos y publicaciones derivados de la misma).

La tesis doctoral de Enrique García de la Riva es excelente por varios motivos. Por un lado profundiza en el funcionamiento de las comunidades leñosas mediterráneas desde la perspectiva de la ecología funcional. Este aspecto es relativamente novedoso y en la actualidad es un tema muy recurrente en ecología. La tesis consta de 7 capítulos: una introducción general, 5 capítulos experimentales y una discusión general. Algunos de los capítulos, en concreto 3, son artículos aceptados en revistas del primer cuartil (PlosOne, J. Veg. Sci., Oikos), y dos artículos están en revisión. Además, durante su trayectoria investigadora, Enrique ha sido muy activo y ha establecido distintas colaboraciones con otros investigadores, dando lugar a varios artículos publicados. En la tesis se desarrollan nuevas metodologías (por ejemplo en el capítulo 2) y se aplican técnicas novedosas como la cuantificación del nicho multidimensional (hipervolumen del capítulo 5). La tesis ha conllevado un enorme esfuerzo de muestreo y análisis, por la diversidad de zonas geográficas, especies de plantas y rasgos funcionales estudiados. Todo esto ha sido posible gracias a que Enrique tiene una capacidad de trabajo impresionante y ha sido capaz de llevar adelante todo el trabajo de su Tesis con alegría.

Por todo ello, se autoriza la presentación de la tesis doctoral.

Córdoba, 11 de Marzo de 2016

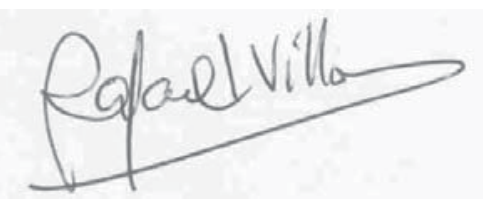

Firma de los director/es
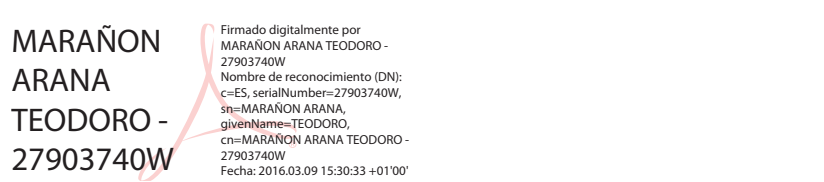

Fdo.: Rafael Villar Montero Fdo.: Teodoro Marañón Arana Fdo: Ignacio M. Pérez Ramos 



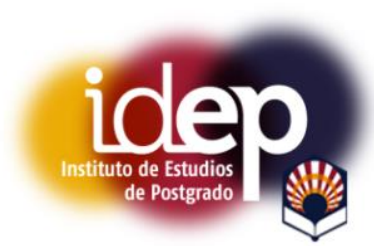

\section{INFORME SOBRE APORTACIONES DERIVADAS DE LA TESIS DOCTORAL Y FACTOR DE IMPACTO DE LAS REVISTAS CIENTÍFICAS (JOURNAL CITATION REPORTS)}

\section{Publicaciones en revistas científicas (Capítulo de la tesis doctoral)}

de la Riva EG, Olmo M, Poorter H, Ubera JL \& Villar R. (2016). Leaf mass per area (LMA) and its relation with leaf structure and anatomy in 34 Mediterranean woody species along a water availablility gradient. PlosOne. (Capítulo 2). Factor de impacto: 3.23, Posición de la revista en relación a su categoría específica (Multidisciplinary sciences) 9/57; primer cuartil (Q1).

de la Riva EG, Tosto A, Pérez-Ramos IM, Navarro-Fernández C, Olmo M, Marañón T \& Villar R. (2015). A plant economics spectrum in Mediterranean forests along environmental gradients: is there coordination among leaf, stem and root traits? Journal of Vegetation Science 27:187-199. (Capítulo 3).

Factor de impacto: 3.71, Posición de la revista en relación a su categoría específica (Ecology) 31/145; primer cuartil (Q1).

de la Riva EG, Pérez-Ramos IM, Navarro-Fernández C, Olmo M, Marañón T \& Villar R. (2015). Disentangling the relative importance of species occurrence, abundance and intraspecific variability in community assembly: a trait-based approach at the whole-plant level in Mediterranean forests. Oikos (DOI: 10.1111/oik.01875). (Capitulo 4).

Factor de impacto: 3.44, Posición de la revista en relación a su categoría específica (Ecology) 35/145; primer cuartil (Q1).

de la Riva EG, Lloret F, Pérez-Ramos IM, Marañón T, Saura-Mas S, Díaz-Delgado R \& Villar R. (Major revision). The importance of functional diversity in the stability of Mediterranean shrubland communities after the impact of extreme climatic events. Journal of Plant Ecology. (Capitulo 6).

Factor de impacto: 2.65, Posición de la revista en relación a su categoría específica (Plant science) 47/204; primer cuartil (Q1).

\section{Otros trabajos en los que ha colaborado}

de la Riva EG, Pérez-Ramos IM, Navarro-Fernández C, Olmo M, Marañón T, \& Villar R. (2014). Rasgos funcionales en el género Quercus: estrategias adquisitivas frente a conservativas en el uso de recursos. Ecosistemas, 23: 82-89.

Factor de impacto en consideración. 
Villar R, López-Iglesias B, Ruiz-Benito P, Zavala MA, \& de la Riva EG. (2014). Crecimiento de plántulas y árboles de seis especies de Quercus. Ecosistemas, 23: 64-72.

Factor de impacto en consideración.

Lloret F, de la Riva EG, Pérez-Ramos IM, Marañón T, Saura-Mas S, Díaz-Delgado R \& Villar R. (2016). Climatic events inducing die-off in Mediterranean shrublands: Are species responses related to their functional traits? Oecología. doi:10.1007/ s00442-016-3550-4.

Factor de impacto: 3.09, Posición de la revista en relación a su categoría específica (Ecology) 40/145; segundo cuartil (Q2).

\section{Otros Artículos enviados}

Freschet G, Valverde-Barrantes O, Craine JM (...), de la Riva EG, SmithWS, Tjoelker M, Wardle D \& Roumet C. (resubmision). A global exploration of fine-root trait variation: opening the black box. Ecology Letters.

Factor de impacto: 10.68, Posición de la revista en relación a su categoría específica (Ecology) 02/145; primer cuartil (Q1).

Navarro-Fernández C, Pérez-Ramos I, de la Riva EG, Vera JR, Roumet C, Villar R \& Marañón T. (resubmision). Functional responses of Mediterranean plant communities to soil resource heterogeneity: a mycorrhizal trait-based approach. Journal of Vegetation Science.

Factor de impacto: 3.71, Posición de la revista en relación a su categoría específica (Ecology) 31/145; primer cuartil (Q1).

\section{Comunicaciones presentadas en congresos}

de la Riva EG, Pérez-Ramos IM, Villar R \& Marañón T. (2015). Functional strategies to cope with resource limitation in Mediterranean woody plant communities. Cuarto congreso Ibérico de Ecología. Coimbra. Comunicación oral. Libro de Resúmenes pp. 104.

de la Riva EG, Lloret F, Pérez-Ramos IM, Marañón T, Saura-Mas S, Díaz-Delgado R \& Villar R. (2014). Diversidad funcional del matorral de Doñana: respuesta a episodios climáticos extremos Jornadas 50 aniversarío de la estación biológica de Doñana. EBD-CSIC. Póster. http://digital.csic.es/handle/10261/93391

de la Riva EG, Pérez-Ramos IM, Navarro-Fernández C, Olmo M, Marañón T \& Villar R. (2013).Functional traits variation across five species of Quercus. Workshop: Oak forests coping with global change: ecology and management. Universidad internacional de Andalucía. Póster. http://digital.csic.es/handle/10261/84689 
de la Riva EG, Pérez-Ramos IM, Navarro-Fernández C, Olmo M, Marañón T \& Villar R. (2013).Respuestas funcionales de comunidades leñosas mediterráneas bajo diferentes escenarios hídricos. $6^{\circ}$ Congreso Forestal Español. Sociedad española de ciencias forestales.

\section{Actas de Congresos}

de la Riva EG, Pérez-Ramos IM, Navarro-Fernández C, Olmo M, Marañón T, \& Villar R. (2013). Respuestas funcionales de comunidades leñosas mediterráneas bajo diferentes escenarios hídricos. $6^{\circ}$ Congreso Forestal Español ISBN: 978-84937964-9-5.

Fernández-Navarro C, de la Riva EG, Vera Marañón JR, Tosto A, Olmo M, PérezRamos IM \& Marañón T. (2013). Diversidad funcional de rasgos radiculares y grado de micorrización de especies leñosas mediterráneas a lo largo de un gradiente de disponibilidad de recursos edáficos. $6^{\circ}$ Congreso Forestal Español. ISBN: 978-84-937964-9-5.

\section{Artículos de divulgación}

Los distintos órganos de la planta (hoja, tallo y raíz) funcionan de manera coordinada.

http://www.irnas.csic.es/los-distintos-organos-de-la-planta-hoja-tallo-y-raizfuncionan-de-manera-coordinada/

http://culturacientificalorenarico.blogspot.com.es/2015/10/las-raices-tallos-y-hojas-de$\underline{\text { las.html }}$

La disponibilidad del agua determina las propiedades funcionales de las comunidades leñosas.

http://www.irnas.csic.es/la-disponibilidad-del-agua-determina-las-propiedadesfuncionales-de-las-comunidades-lenosas/

http://www.uco.es/uconews/es/article/la-disponibilidad-del-agua-determina-laspropiedades-funcionales-de-las-com/

Raíces, semillas y hojas que se adelantan al cambio climático.

https://www.fundaciondescubre.es/blog/2016/03/07/raices-semillas-y-hojasque-se-adelantan-al-cambio-climatico/ 

Esta tesis esta dedicada a mi mujer (Diana) y a mi hija (Gael), par cada segunda que os ha robada de mi tiempa... gracias par unestra kaciencia, as quiera.

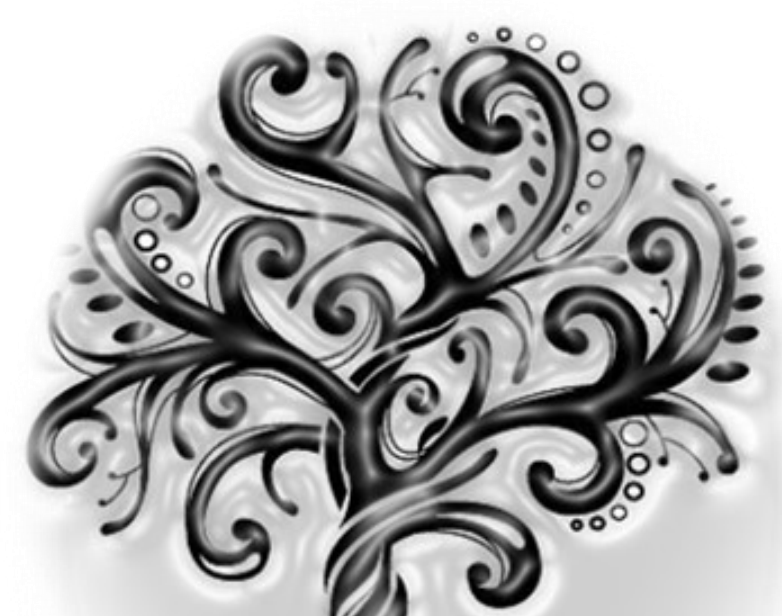

Si el sol na calentara. si la luna na existiera.

10 1 entances, no tendría

sentida vivir en esta tierra coma tampaca tendría sentida vivir sin mi vida. la mujer de mis sueños. la que me da la alegría...

Por Siempre (Mario Benedetti) 



\section{Índice}

Prólogo

Resumen

Summary

Capítulo 1. Introducción general

Capítulo 2. Leaf mass per area (LMA) and its relation with leaf structure and anatomy in 34 Mediterranean woody secies along a water availability gradient

Capítulo 3. A plant economics spectrum in Mediterranean forests along environmental gradients:lis there coorGiation among leaf, stem and root traits?...... س.

Capítulo 4. Disentangling the relative importance of species occurrence, abundance and intraspecific variability in community assembly: a trait-based approach at the whole-plant level in Mediterranean forests

Capítulo 5. A multidimensional functional approach reveals the imprint of environmental stress in Mediterraneam woody plants

Capítulo 6. The importance of functional diversity in the stability of Mediterranean shrubland communities after the impact of extreme climatic events

Capítulo 7. Discusión general

Conclusiones

Agradecimientos

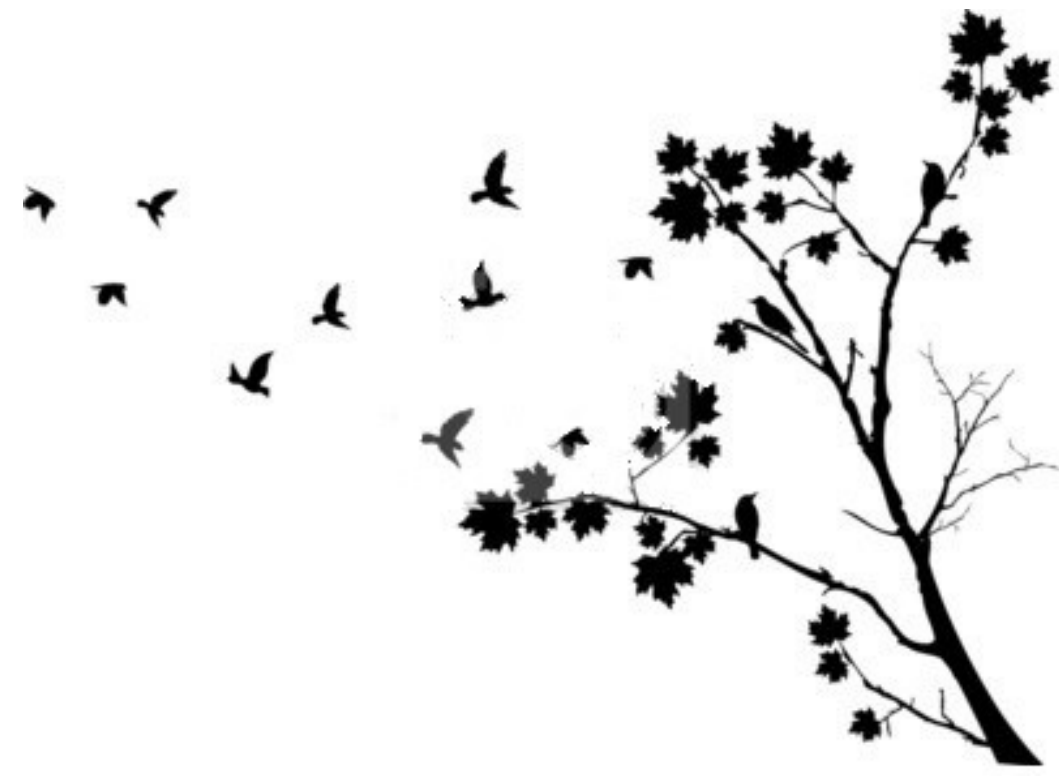





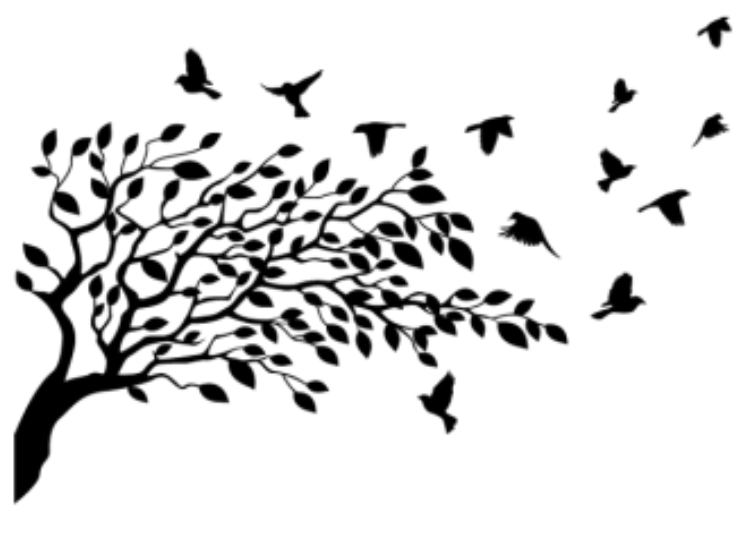

\title{
"El más triste aspecta de la vida ahora misma es que la ciencia alcanza el conocimienta más rápida que la sociedad alcanza la sabiduría"
}

\author{
Isaac Asimov
}

\section{Prólogo}

En la actualidad más del $60 \%$ de los servicios ecosistémicos a nivel global están sufriendo un importante deterioro o están siendo sobreexplotados (Millennium Ecosystem Assessment 2005). Dando por cierta esta premisa, resulta de imperiosa necesidad por un lado el desarrollar el conocimiento básico relativo a los diferentes procesos ecosistémicos que tienen lugar y por otro detectar los problemas al que se enfrentan los mismos como resultado de la presión antrópica. Este es uno de los principales retos de la ecología (como demuestra la amplísima bibliografía científica a este respecto) y la base en la que se fundamenta el proyecto Diverbos (Diversidad funcional y resiliencia del bosque mediterráneo; http://www.diverbos.com/es). El proyecto Diverbos ha sido desarrollado principalmente por los investigadores Rafael Villar, Teodoro Marañón e Ignacio M. Pérez-Ramos, con la inquietud de ampliar el conocimiento de los procesos ecosistémicos que tienen lugar en los bosques mediterráneos, habiéndose obtenido entre otros resultados el presente cuerpo de tesis.

No es la intención comenzar de forma alarmista, pero si es una realidad que las actividades humanas están provocando cambios en las condiciones ambientales que afectan inexorablemente los procesos ecosistémicos, por ejemplo como consecuencia del cambio climático. En este sentido, este prólogo es una motivación personal con la que se pretende acercar a cualquier lector la importancia y relevancia de nuestro trabajo, señalando la problemática actual a las que se enfrentan nuestros ecosistemas. Esto se hace especialmente relevante, bajo el marco de una sociedad basada en el consumo que cuantifica todo en función de un valor generalmente económico y que frecuentemente olvida los bienes y servicios que proveen nuestros bosques (p.ej. regulación de gases atmosféricos, influencia en el ciclo del agua, producción primaria), siendo básico la conservación de los mismos para el ser humano (FAO, 2010). Con frecuencia la gente fuera del mundo científico me pregunta "¿para qué sirve lo que hacemos?", esta cuestión que puede ser relativamente "sencilla" de responder en nuestro entorno científico, resulta alarmantemente incomprensible fuera del mismo. Tratando de responder a la pregunta, considero que se puede abordar desde diferentes puntos de vista, y me gustaría destacar dos: desde la perspectiva de la ética considero que nuestro trabajo es la forma de pagar una deuda, aunque sea mínimamente, en forma de conocimiento por todo el daño que le hacemos a nuestro entorno y a los seres vivos que tienen que coexistir con nosotros; desde un punto de vista práctico la idea es generar el suficiente conocimiento para posteriormente ser aplicado tanto en restauración de ecosistemas, planes de gestión y conservación, o tratar de evitar, o al menos amortiguar, los efectos negativos de nuestras actuaciones con el medio ambiente. 
Si bien es una forma muy sucinta de justificar nuestro trabajo, espero que el lector a lo largo de esta tesis entienda la importancia que tiene la ecología y en particular la ecología funcional para el desarrollo sostenible de nuestra sociedad, en especial mis familiares y amigos a los que a priori agradezco el esfuerzo de leer esta tesis a pesar de la complejidad derivada de la propia idiosincrasia de la materia. 


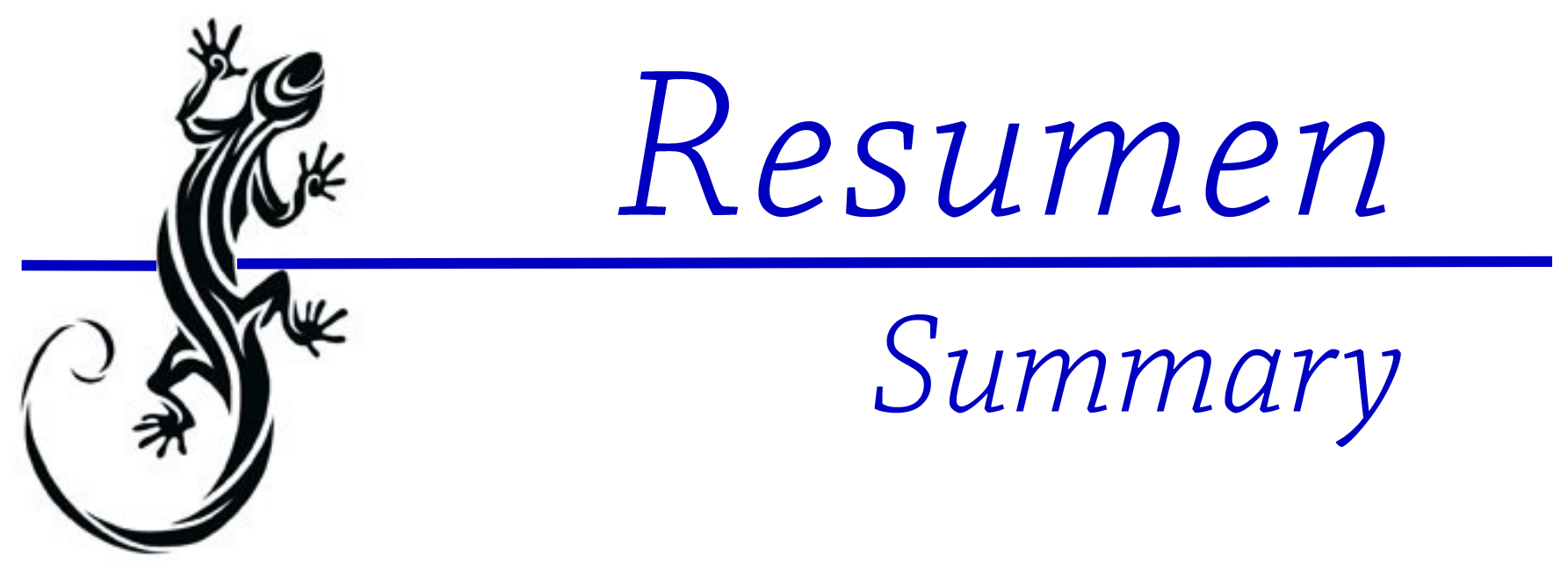

"Si namos a contar una histaria contémasla bien"

En el nombre del viento

(Patrick Rothfuss)

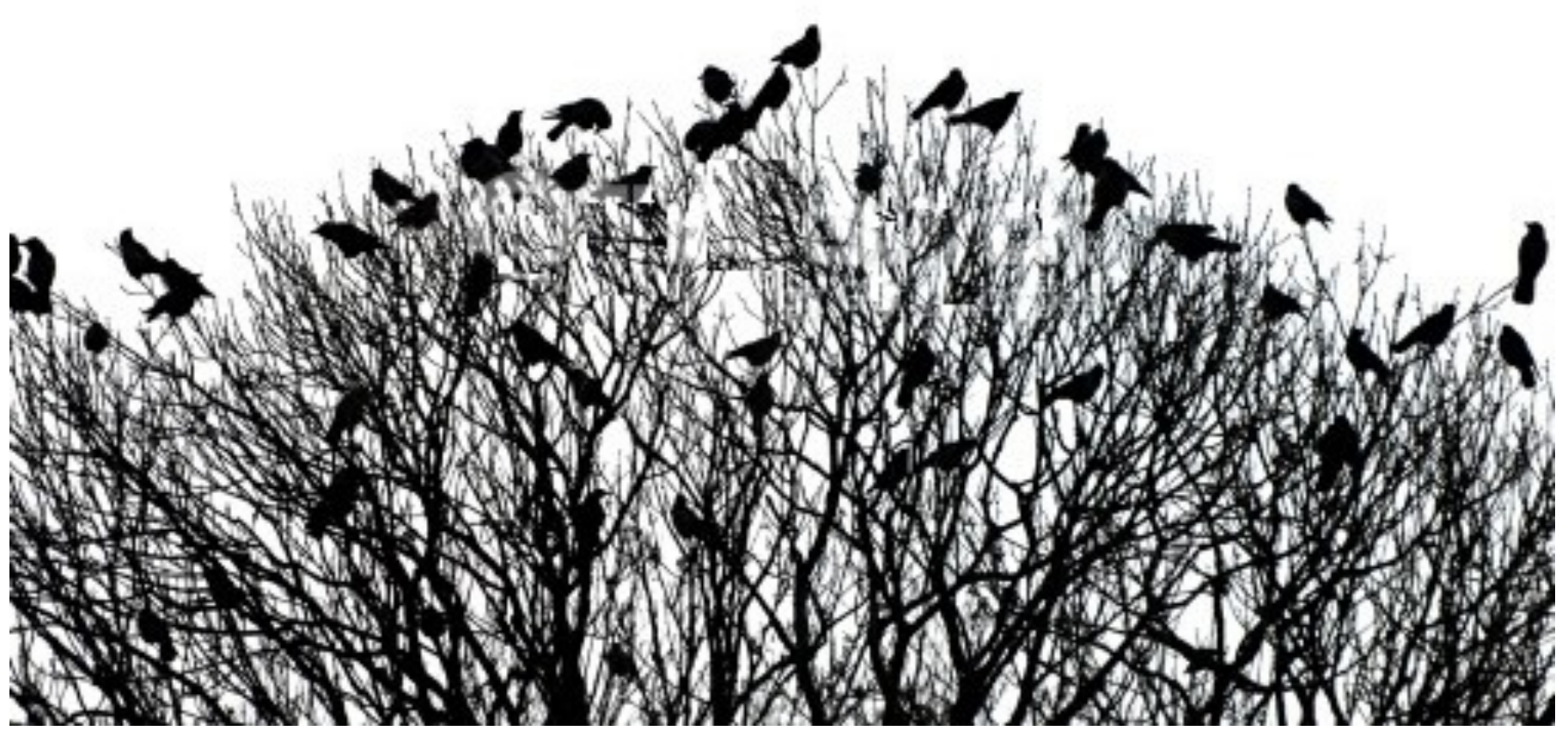



Los rasgos funcionales se pueden definir como las características de los organismos que permiten la adecuación de los mismos a un entorno dado. La aproximación funcional de la Ecología Vegetal permite estudiar tanto las interacciones existentes entre los individuos que componen una comunidad como la de éstos con su medio ambiente en un gran número de especies, abordando cuestiones relacionadas con las estrategias funcionales, los patrones de ensamblaje de comunidades y de distribución de especies a lo largo del paisaje, y los procesos ecosistémicos que originan. El objetivo general de la tesis consiste en entender mejor las estrategias que desarrollan las diferentes especies para persistir en un ambiente determinado, así como las reglas que gobiernan el proceso de ensamblaje de plantas leñosas mediterráneas, desde el marco conceptual de la ecología funcional. Para abordar estos objetivos generales se utilizan diferentes aproximaciones, a diversas escalas de estudio, que componen un total de 5 capítulos (además de la Introducción y la Discusión general):

El capítulo 2 está centrado a nivel foliar. Se estudia la variación del peso específico foliar (relación masa de la hoja y área, LMA) en 34 especies leñosas (20 perennifolias y 14 caducifolias) seleccionadas a lo largo de un gradiente ambiental en Sierra Morena. Este rasgo funcional es uno de los principales indicadores del funcionamiento de las plantas, pero no se conoce completamente qué componentes estructurales condicionan su variación. Este estudio reveló que la variación de LMA resulta de la variación del grosor y de la densidad de la hoja, independientemente del hábito foliar. A su vez, las variaciones del grosor de la hoja estaban relacionadas positivamente con el grosor del mesófilo. Si bien en las especies de hoja perennifolia otros rasgos histológicos (como el grosor de la epidermis, de los tejidos vasculares y de los espacios aéreos) también estuvieron implicados. Además, los factores ambientales parecen ejercer un efecto significativo en la selección de especies con ciertos rasgos foliares, encontrándose las especies con valores más elevados de LMA y mayor densidad foliar en las zonas más secas.

En el capítulo 3 se analiza la coordinación funcional de rasgos funcionales de hojas, tallos y raíces en 38 especies de plantas leñosas, seleccionadas a lo largo de un gradiente ambiental local (Sierra Morena). Las plantas, al igual que muchos organismos, presentan distintos órganos especializados en diversas funciones. Las hojas están especializadas en captar la luz, las raíces en absorber el agua y los nutrientes del suelo, y el tallo en transportarlos a las hojas. Dada la diversificación de funciones, podría ser esperable que las características de los distintos órganos sean muy diferentes. Existe un intenso debate sobre si estas características o atributos de las hojas, tallos y raíces funcionan de forma coordinada o no. La aclaración sobre este dilema aportaría luz a cómo funcionan las plantas y así poder predecir mejor los efectos potenciales de los cambios ambientales, como aquéllos derivados del cambio climático, sobre la composición de las comunidades vegetales. Este estudio reveló una gran coordinación entre los rasgos funcionales de los diferentes órganos. Por ejemplo, las especies que presentaron una alta densidad en el tallo, también la mostraron a nivel de hoja y raíz. Estos resultados apoyan la existencia de un "espectro de economía" a nivel de la planta entera en especies leñosas mediterráneas. Por otro lado, esa misma coordinación entre órganos se ha comprobado a nivel de comunidad, encontrándose valores de coordinación aún más altos. Además, encontramos que la distribución de las distintas comunidades a lo largo de un gradiente de humedad en el suelo siguió un patrón muy definido. Así, las zonas con menor disponibilidad de agua están domi- 
nadas por comunidades en las que las especies presentan un uso más conservativo de los recursos, mientras que en zonas más húmedas dominan las especies con una estrategia más adquisitiva, con un uso más derrochador de los recursos. Sin embargo, esta coordinación entre órganos se vuelve débil o desaparece cuando restringimos el análisis a grupos de especies que coexisten bajo un determinado ambiente, sugiriendo que la diversificación de estrategias dentro de una comunidad (a menor escala espacial) no está relacionada con el espectro de economía.

En el capítulo 4 se analizan los factores que regulan la estructura funcional de las comunidades vegetales a lo largo de un gradiente ambiental a escala local (Sierra Morena). Esta aproximación nos permite discernir los mecanismos de filtrado de especies que están teniendo lugar y nos ayuda a comprender mejor los patrones de ensamblaje de especies de estas comunidades. Se analizó la variación funcional en nueve comunidades de especies leñosas a lo largo de un gradiente natural de nutrientes y humedad, tomándose muestras de rasgos funcionales tanto aéreos (tamaño de la planta, área específica foliar, contenido en materia seca de tallo y hoja, etc.) como subterráneos (contenido de materia seca y longitud específica radicular) en 38 especies leñosas mediterráneas. En este capítulo se propone un método practico para cuantificar la importancia relativa del reemplazo de especies (distinguiendo entre variación en la composición o la abundancia) o la variación intraespecífica a lo largo del gradiente. La variación de los rasgos funcionales en las comunidades estuvo muy relacionada con la disponibilidad de agua en el suelo, mientras que la disponibilidad de los nutrientes tuvo un papel secundario. A su vez, los cambios en la estructura de las comunidades fueron consecuencia de la variación en la composición de especies. Estos resultados confirman la importancia del agua en ecosistemas mediterráneos, destacando como novedoso que dicha variación de agua a escala local puede dar lugar a grandes cambios en la estructura funcional de la comunidad. Estos cambios no solo son debidos a un reemplazo en la composición de especies de la comunidad, sino también a la composición funcional de las mismas. Los resultados obtenidos son especialmente relevantes en el marco actual de cambio climático; se espera un aumento generalizado de la aridez, que puede tener consecuencias negativas para las comunidades asociadas a zonas más húmedas, tanto por la desaparición de algunas especies, como por la alteración de los diferentes procesos ecosistémicos asociados a las mismas.

En el capítulo 5 se analiza la variación de la estructura funcional de las comunidades leñosas mediterráneas a lo largo de un gradiente regional de aridez en Andalucía (sur de España). Se cuantificó la magnitud del espacio funcional (hipervolumen) de las comunidades leñosas a lo largo de dicho gradiente, basado en el concepto de nicho multidimensional de Hutchinson. La estructura funcional de las comunidades varió a lo largo del gradiente de aridez. Las comunidades situadas en las zonas más húmedas mostraron mayores hipervolúmenes (mayor espacio funcional), si bien la mayoría de especies presentaron rasgos funcionales asociados a estrategias adquisitivas. Por el contrario, las comunidades de las zonas más áridas presentaron hipervolúmenes de menor tamaño y especies caracterizadas por rasgos más típicos de una estrategia conservativa. La aridez actúa como un filtro ambiental que condiciona la estructura funcional de la comunidad, limitando a su vez su diversidad funcional; los resultados apoyan a los modelos que predicen una disminución de la diversidad funcional en condiciones más estresantes. Sin embargo, esta variación del espacio funcional depende en gran medida de la dimensión (p.ej. hoja o raíz) que 
se tenga en consideración, resaltando la importancia de la selección de los rasgos en este tipo de estudios.

En el capítulo 6 se evalúa la relación entre estructura funcional y los mecanismos de estabilidad (resistencia y resiliencia) de las comunidades de matorral en el Parque Nacional de Doñana, en respuesta a un evento climático extremo (sequía y frío) sucedido en el año 2005. Se analizó la variación funcional temporal tanto a nivel de rasgos (medias ponderadas a nivel de comunidad, CWM) como de diversidad (riqueza, equidad y divergencia) en 18 comunidades de "monte blanco". El evento climático propició pequeñas variaciones en la estructura funcional de las comunidades durante los primeros años, si bien estas comunidades mostraron gran resiliencia a lo largo del tiempo. Por ejemplo, se apreció inicialmente una ligera caída de la riqueza funcional en las comunidades, recuperándose ocho años después los niveles de diversidad inicial. Un resultado destacado fue que, a pesar de la gran estabilidad funcional, las comunidades que presentaron mayores niveles de diversidad funcional también fueron las más propensas a sufrir cambios en la composición de especies; este resultado se puede explicar mediante el reemplazo de especies con características funcionales similares. A su vez, se encontró una escasa relación entre los rasgos funcionales y la estabilidad de la comunidad; por una parte las comunidades más resistentes al evento climático fueron las que exhibieron un mayor contenido en materia seca de la raíz, mientras que las más resilientes mostraron valores más altos de clorofila en la hoja. En general, en este estudio demuestra el desarrollo de mecanismos de estabilidad en las comunidades de matorral mediterráneas frente al estrés generado por eventos climáticos extremos, cuya ocurrencia se verá incrementada en el futuro de acuerdo con las predicciones de los modelos de cambio global.

La ecología funcional se ha aplicado a las comunidades leñosas mediterráneas, en una variedad de niveles de organización (desde la anatomía de la hoja, los diferentes órganos, la planta completa, la población y la comunidad), y escalas espaciales (local y regional), mostrándose como una herramienta muy útil en el análisis de la ecología de estos ecosistemas. Esta aproximación funcional nos ha permitido desgranar tanto las estrategias funcionales de las distintas comunidades leñosas mediterráneas como los patrones de ensamblaje de especies a lo largo de los diferentes gradientes ambientales y escalas analizadas. En definitiva el presente cuerpo de tesis ofrece una base de conocimiento consistente de los ecosistemas mediterráneos y de cómo sus componentes operan a lo largo de diferentes gradientes ambientales. 
Functional traits can be defined as the characteristics of organisms that allow them to persist in a given environment. The functional approach of Plant Ecology allows studying the interactions between individuals within a community, and the interactions of these individuals with their environment for a large number of species. Thus, the functional approach can be connected to issues related with functional strategies, assembly rules and species distribution along the landscape, as well as ecosystem processes. The overall aim of this Thesis is to better understand the strategies developed by different species to persist in a given environment as well as the assembly rules of Mediterranean woody plant communities, within the conceptual framework of functional ecology. To address these broad objectives, we developed different approaches, at different scales of study, making up a total of 5 chapters (plus Introduction and general Discussion):

The chapter 2 is focused at leaf level. In this chapter we studied the leaf mass per area (LMA) variation on 34 (20 evergreen and 14 deciduous) woody plant species selected along a local environmental gradient in Sierra Morena (south Spain). LMA is a morphological leaf trait widely used as a good indicator of plant functioning; however, the structural components which underlie the interspecific variation in LMA are still poorly understood. This study showed that variation in LMA was due to variation in both leaf thickness and density. In turn, leaf thickness variation was positively related with mesophyll. In evergreen species, other anatomical tissues (such as epidermis, vascular tissue and air spaces) were found positively related as well. In addition, different environmental conditions may impose different selective pressures on plants species with certain leaf traits, appearing species with higher values of LMA and leaf density in drier areas.

In the chapter 3 the functional coordination of leaves, stems and root traits on 38 woody plant species selected along a local environmental gradient (Sierra Morena) is analyzed. Plants, like so many organisms, have several organs that are specialized for different functions. Thus, the main role of leaves is light capture, while roots are related with soil water and nutrient uptake, and stems supply these resources to leaves. According with their functional diversification, differences among organ characteristics could be expected. Currently, an intense debate in plant ecology exists about the coordination among leaf, stem and root traits. Understanding this issue could help to bring some clarification about how plants function, as well as to discern the potential effects of environmental changes (such as those derived from climatic change predictions) on plant community structure. This study revealed a high degree of functional coordination between traits belonging to different plant organs. For example, species with higher stem density showed also higher values of leaf and root density. These results suggest the existence of an "economics spectrum" at whole plant level in Mediterranean woody plant species. On the other hand, the same coordination between traits was found at community level, with stronger relationships at this hierarchical level. In addition, we found that the distribution of plant communities along the soil moisture gradient followed a clear pattern. Thus, drier areas were dominated by communities with a higher dominance of species associated with a more conservative use of resources, while wetter areas were dominated by species with a more acquisitive strategy. However, the general trend of coordination between traits of different organs became weaker or disappeared at a lower spatial scale, when considering groups of species belonging to environmentally similar sites. This suggests that the diversification of strategies within communities was not related to the economics spectrum at a lower spatial scale.

The chapter 4 is mainly focused on the factors that govern the functional structure of plant communities along a local environmental gradient (in Sierra Morena mountains). Thus, the functional approach allows us to discern the filtering mechanisms and the distribution patterns that take place in these communities. The functional trait variation of nine woody plant communities was analysed along a wide soil resource gradient. For this approach, several functional traits at both aboveground (plant size, specific leaf area, leaf and stem dry matter content, etc.) and belowground (root dry matter content and specific root length) level were quantified in 38 Mediterranean woody plant species. A new practical method to quantify the 
relative importance of species turnover (distinguishing between species occurrence and abundance) versus intraspecific variation was proposed. The results showed that functional trait variation of communities was highly determined by soil water storage. In addition, changes of the community functional structure were mainly due to changes in species occurrence. These results confirm the important role of water availability in Mediterranean ecosystems, highlighting that variation of this resource may promote large changes at local scale in the community functional structure. These changes were not only due to a process of species replacement but also to changes in the functional composition of the communities. These results are especially relevant under a context of global change, which predicts an increase of aridity in the study area. These findings suggest that the expected increasing aridity will cause a strong alteration in species composition, especially in wetter sites, promoting the disappearance of several species and, consequently, the alteration of the ecosystem processes associated with them.

In the chapter 5 the variation of the functional structure of the Mediterranean woody communities is analysed along a regional environmental gradient in Andalusia (south of Spain). We quantified the niche differences using the n-dimensional space approach (hypervolumen), which is based on the Hutchinsonian's multidimensional niche concept. We found consistent variation of communities' functional structure along the aridity gradient. The wetter communities showed greatest hypervolumes (greatest functional space), although most of the species showed functional traits related with acquisitive strategies. On the contrary, the communities from driest zones showed smaller hypervolumes and species with traits related with conservative strategies. These results indicate that aridity acts as an important abiotic filter affecting the community trait structure, in turn limiting their functional diversity. The results support the models that predict a decrease in functional diversity under harsh climatic conditions. However, functional diversity patterns can largely depend on the selected functional plant dimension (i.e. leaf or root), highlighting the importance of selecting meaningful traits to interpret this type of studies.

In the chapter 6 it was analysed the relationship among the functional structure and the mechanisms underlying community stability (resistance and resilience) in shrubland communities of Doñana National Park, in response to an extreme climatic event (drought and cold) which took place in 2005. The temporal variation in 10 functional traits at the community level (community weighted means, CWM) and functional diversity (functional richness, evenness and divergence) was quantified in 18 communities of "monte blanco". The extreme climatic event induced several variations on community functional structure in the first years, but these communities showed a great resilience over time. For example, it was detected a slight fall in the functional richness of the communities just after the climatic episode that returned to the pre-event conditions after eight years. One prominent result was that, despite the great functional stability, communities with higher levels of functional diversity were more prone to changes in species composition; this could be possible by replacing species with similar functional characteristics. In addition, it was found a poor relationship between functional traits and stability of the community, the most resistant communities being those with higher values of root dry matter, while the most resilient communities having higher values of leaf chlorophyll. In general, this study shows the existence of important mechanisms of stability in Mediterranean shrubland communities exposed to extreme climatic episodes, which will be more frequent in the near future in accordance with the global change predictions.

Results from this doctoral thesis support the use of the functional approach as a powerful tool to study different ecological processes in Mediterranean woody plant communities. In the different chapters of this thesis, different levels of organization (from the leaf to the whole community), and spatial scales (local and regional) have been taken into account. This functional approach has allowed us to discern the array of functional strategies that coexist in different Mediterranean woody communities as well as the assemblage patterns operating along different environmental gradients and scales. Ultimately, this Thesis provides a consistent knowledge of Mediterranean ecosystems and how their components operate along different environmental gradients. 


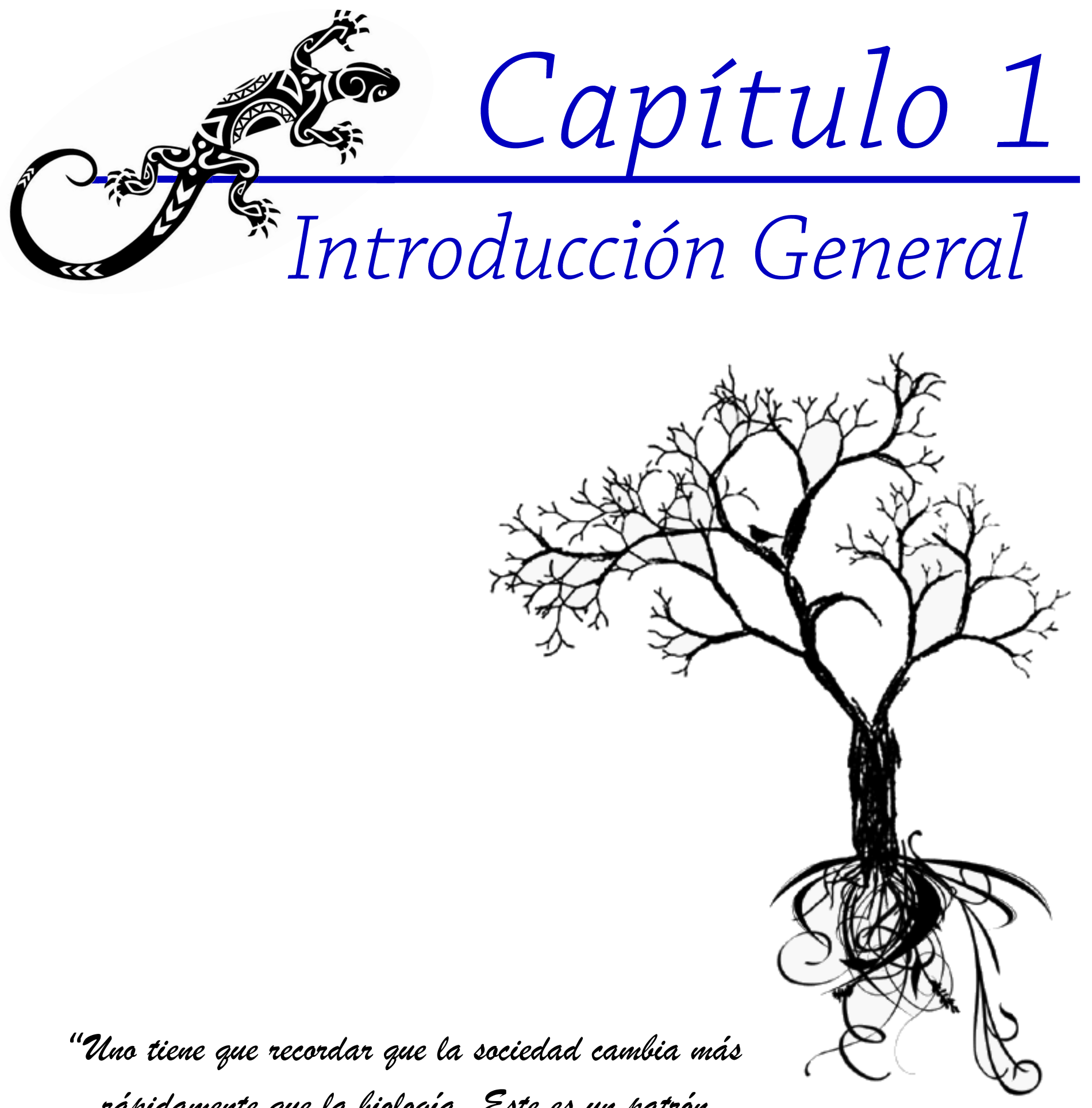

"Una tiene que recordar que la saciedad cambia más rápidamente que la bialogia. Este es un patrón bialógica que lleva media millón de añas y na puede ser ignarada de un dia para otra y menos cuanda no hay ventaja alguna haciéndala"

Peter Fleming 



\section{Marco conceptual general. La ecología funcional como herramienta útil para el estudio}

\section{de comunidades de plantas}

Los estudios sobre ecología de comunidades de plantas han sido abordados desde dos enfoques diferenciados. Clásicamente, la mayor parte de ellos estaban centrados en la diversidad de especies (p.ej. número de especies que coexisten en un momento y lugar determinados) ignorando las características funcionales de las mismas (Yodzis 1978; May 1981; Grover 1997). En cambio, otra corriente de la ecología ha destacado los aspectos funcionales y las características de las especies como indicadores de su ecología (Raunkiaer 1934; Grime 1977; Noble y Slatyer 1980), ayudándonos a entender las estrategias y distribución de las mismas en la naturaleza (Wright et al. 2007). Durante las últimas dos décadas ha habido un amplio desarrollo de dicha aproximación funcional, utilizándose en gran número de estudios científicos, lo que ha permitido grandes avances en el campo de la ecología de comunidades de plantas. Como ejemplo, si hacemos una búsqueda en "google académico" utilizando como palabra clave functional traits (rasgos funcionales en inglés), aparecen un total de 1.9 millones de resultados, perteneciendo la gran mayoría de ellos (1.3 millones) a referencias de los últimos 15 años (búsqueda realizada el 1 de Septiembre del 2015). Estos resultados nos dan una idea cuantitativa del desarrollo e importancia que ha tenido la ecología funcional en el siglo XXI y del potencial que tiene este campo no solo desde un punto de vista de ciencia básica sino también aplicada, dado su potencial interés para la gestión y conservación de ecosistemas tanto naturales como manejados por el hombre (ver Garnier y Navas 2012).

En líneas generales, la ecología funcional trata de abordar cómo y por qué los sistemas ecológicos y sus componentes operan a lo largo de los diferentes gradientes ambientales (Garnier y Navas 2012). En este sentido, una de las principales ventajas que ofrece la aproximación funcional es la capacidad que tiene de abarcar tanto las interacciones existentes entre los individuos que componen una comunidad como la de éstos con su medio ambiente en un gran número de especies, permitiéndonos abordar cuestiones relacionadas con las estrategias funcionales que desarrollan las diferentes especies, los patrones de ensamblaje de comunidades y distribución de especies a lo largo del paisaje o los procesos ecosistémicos que originan (Escudero y Valladares 2016).

\subsection{Los rasgos funcionales}

Los rasgos funcionales constituyen la base de la ecología funcional, pudiéndose definir como las características de las plantas que permiten la adecuación de las mismas a su entorno. Una definición más técnica y completa es la de Violle et al. (2007): "Ias características morfo-fisio-fenológicas que influyen directa o indirectamente en la adecuación (fitness) de la planta al ambiente a través de sus efectos sobre el crecimiento, la reproducción y la supervivencia". De acuerdo con Garnier y Navas (2012), los rasgos funcionales deben cumplir cuatro requisitos:

I. Tener cierta relación con la función de la planta.

II. Ser relativamente fáciles de observar y cuantificar.

III. Ser cuantificables a través de protocolos estandarizados para una amplia gama de especies. 
IV. Tener una graduación consistente entre las especies cuando las condiciones ambientales varían.

Los rasgos funcionales pueden clasificarse en dos grandes tipos, según Lavorel y Garnier (2002): (i) rasgos respuesta (del inglés "response traits"), que son aquéllos que responden ante unas condiciones ambientales determinadas, como por ejemplo los rasgos relacionados con la fecundidad, la regeneración o la dispersión; y (ii) rasgos de efecto (del inglés "effect traits") que son aquéllos que ejercen un determinado efecto en los ecosistemas, resultando en buenos predictores de determinadas funciones ecosistémicas, como por ejemplo es el caso de los rasgos relacionados con el reciclado y almacenamiento de nutrientes (Suding et al. 2008). Sin embargo, esta dicotomía a veces no es tan evidente debido a la existencia de cierta convergencia ante determinadas perturbaciones ambientales (Lavorel y Garnier 2002).

\subsection{La diversidad funcional}

Aunque clásicamente la diversidad vegetal se ha cuantificado usando índices basados en la riqueza y abundancia de especies (Whittaker 1975; Lande 1996), en las últimas décadas ha habido un crecimiento exponencial en el uso del término "diversidad funcional" (Schleuter 2010). A diferencia de la diversidad taxonómica, la diversidad funcional mide la distribución y el rango de los rasgos funcionales de los organismos presentes en las comunidades, considerando tanto la complementariedad como la redundancia de las especies coexistentes (Díaz y Cabido 2001; Petchey y Gastón 2006). Así, podemos definir la diversidad funcional como el grado de variación de los rasgos funcionales de las especies coexistentes (Weiher 2011), siendo un factor importante para desentrañar la relación entre los cambios ambientales, la composición de la comunidad y los procesos del ecosistema (Loreau 1998; Chapin et al 2000; Tilman 2001; Lavorel et al. 2008). La diversidad funcional es una componente importante de la biodiversidad (Petchey y Gaston 2002) y su principal diferencia con la diversidad taxonómica es que enfatiza la diferencia fenotípica entre taxones obviando la relación filogenética (Weiher 2011).

La complementariedad entre la riqueza de especies y sus características funcionales nos ofrece una visión más clara sobre la relación existente entre la diversidad y los procesos de los ecosistemas, contribuyendo de forma clara a la gestión de los servicios ecosistémicos (Díaz y Cabido 2011). En este sentido, unos valores más altos o más bajos de diversidad funcional pueden influir de manera decisiva en el funcionamiento de los ecosistemas. Un ejemplo es el aumento en la eficiencia del uso de los recursos como resultado de la coexistencia de organismos con un elevado rango de variación funcional (Hooper y Vitousek 1997; Weiher 2010), habiéndose comprobado que una mayor diversidad funcional aumenta la productividad primaria en pastizales (p.ej. Tilman et al. 1997; Hooper y Vitousek 1997). Otros procesos ecosistémicos relacionados con la diversidad son los efectos relativos a la facilitación, de modo que el funcionamiento de ciertas especies se ve reforzado por la presencia de otras (Mulder et al 2001; Cardinale et al. 2002).

Las actividades humanas están alterando muchos procesos ecosistémicos (Tilman et al. 2001), bien por la acción directa sobre la diversidad o por alteración de los diferentes factores ambientales, que modifican a su vez la diversidad funcional de las comunidades (Villeguer et al. 2010). Esto ha puesto en 
alerta a los investigadores, desarrollándose durante las últimas décadas diferentes métodos para cuantificar la diversidad funcional (ver Schleuter et al. 2010 y sus referencias). En general, estos índices describen dos aspectos relevantes de la diversidad funcional: (i) la cantidad de espacio de nicho funcional ocupado por las especies existentes, denominado riqueza funcional, y (ii) cómo se ocupa este espacio, denominado uniformidad funcional y divergencia funcional. Algunos términos e índices relacionados con la diversidad funcional son los siguientes:

- $\quad$ Riqueza funcional: Este índice representa la cantidad de espacio funcional ocupado por la comunidad. Es un índice independiente de la abundancia y generalmente está correlacionado con el número de especies (aumentando al incrementar la riqueza de especies), si bien dos comunidades con el mismo número de especies no tienen por qué poseer la misma riqueza funcional (Schleuter et al. 2010). Cuantifica el volumen generado por los valores máximos y mínimos de cada uno de los rasgos, teniendo tantas dimensiones como rasgos funcionales se utilicen en el cálculo (Villeguer et al. 2008).

- Equidad funcional: Este índice describe la homogeneidad de la distribución de la abundancia en un espacio funcional dado (Mason et al. 2005), y mide tanto la regularidad del espaciado entre las especies a lo largo de un gradiente del rasgo funcional como la uniformidad de la abundancia de las mismas (Villeguer et al. 2008).

- $\quad$ Divergencia funcional: Para un rasgo particular la divergencia funcional representa cómo la abundancia de las especies se extiende a lo largo del eje funcional (Mason et al. 2005). Así, este índice representa la variación funcional ponderada por la abundancia de las distintas especies. Este índice decrece cuando las especies más abundantes tienen valores próximos al valor medio del rango funcional, siendo mayor cuando las especies más abundantes tienes valores más extremos respecto al rango funcional (Villeguer et al. 2008).

- $\quad$ Hipervolúmenes: Es un índice basado en el concepto de nicho multidimensional propuesto por Hutchinson (1957), el cual nos permite cuantificar el espacio de nicho de una comunidad mediante la evaluación del hipervolumen creado por los rasgos funcionales y que caracteriza el espacio fenotípico ocupado por un conjunto determinado de especies (Lamanna et al. 2014). Al igual que la riqueza funcional, este índice no tiene en cuenta la abundancia pero, pero a diferencia de esta, el volumen generado no tiene por qué ser continuo ni lineal, mejorando la precisión del volumen ocupado por las diferentes dimensiones funcionales (lo que se conoce como el umbral multivariante de densidad de Kernel; ver Blonder et al. 2014). Estos modelos analizan la distribución funcional de las especies, permitiéndonos ver por un lado si hay un continuo funcional en una comunidad dada, o si por el contrario existen huecos. Por otro lado, nos permiten discernir qué cantidad de hipervolumen solapa entre las comunidades (nos puede ser útil para discernir exclusión competitiva) así como la redundancia funcional de las especies que las constituyen.

\subsection{Estrategias funcionales y coordinación entre rasgos}

Se han propuesto diferentes modelos con la finalidad de clasificar las estrategias ecológicas de las plantas de acuerdo con el espectro de variación de sus rasgos funcionales a lo largo de diferentes ejes de especialización. Uno de los modelos más relevantes fue el propuesto por Grime (1977), quien argumentaba que las especies se podían 
distribuir de acuerdo con la forma de crecimiento y/o establecimiento a lo largo de tres ejes definidos por la capacidad competitiva (C), tolerancia al estrés (S) y la respuesta a las perturbaciones o capacidad ruderal (R). Estos ejes estarían caracterizados por la posesión de un determinado conjunto de rasgos ecológicos, morfológicos o fisiológicos, si bien no fue pre-establecida la identidad de los rasgos que debían cuantificarse, careciendo este modelo de una base teórica formal (Silvertown 1992). A partir del esquema CSR propuesto por Grime, Westoby (1998) desarrolló otro modelo denominado LHS, según el cual el área específica foliar de la hoja (eje L) reflejaría la variación en la respuesta de la captación de recursos y crecimiento de una determinada especie, mientras que el eje $R$ se podía diferenciar en dos ejes diferentes en función de su altura $(\mathrm{H})$ y del peso de la semilla $(\mathrm{S})$. Este modelo define claramente los rasgos funcionales que se deben cuantificar, facilitando la extrapolación de resultados entre diferentes estudios, así como la comparación entre diferentes grupos funcionales o taxonómicos.

En relación a la eficiencia en el uso de los recursos, uno de los ejes de especialización más conocidos es el que se define como "espectro de economía" (del inglés "Economics Spectrum"; Díaz et al. 2004; Wright et al. 2004), que está basado en el compromiso entre la inversión de recursos en los diferentes tejidos de la planta frente a su perdurabilidad y grado de resistencia a diferentes tipos de estrés ambiental (de la Riva et al. 2014), afectando tanto a los rasgos respuesta como a los de efecto (Suding et al. 2008). Así, por un lado, existen especies con valores de rasgos asociados a una rápida adquisición de recursos y tasas de crecimiento más elevadas, que contrastan con otras especies de crecimiento lento que poseen valores de rasgos que les permiten maximizar la conservación de los recursos (Reich et al. 1998; Wright y Westoby 2001; Villar et al. 2006; Poorter y Garnier 2007).

Las plantas son organismos que desarrollan diferentes soluciones para poder establecerse, crecer y reproducirse bajo unas condiciones ambientales dadas (Laughlin 2014). Cada órgano (p.ej. hoja, tallo, raíz) de la planta puede ofrecer información potencialmente única sobre el funcionamiento de la misma en un entorno dado (Laughlin 2014), pero existe un sesgo a favor del estudio de los rasgos aéreos respecto a los subterráneos, posiblemente por ser más fáciles de cuantificar (Holdaway et al. 2011). Es por ello que los estudios relacionados con estrategias funcionales se han centrado mayoritariamente en rasgos aéreos (Wright et al. 2005; Liancourt et al. 2009; Golodets et al. 2009; Heberling y Fridley 2012; Sack 2013), si bien en la actualidad esta tendencia está cambiando, dado el creciente número de trabajos que incluyen rasgos radiculares (p.ej. Laughlin et al. 2010; Fortunel et al. 2012; Pérez-Ramos et al. 2012; Prieto et al. 2015). Las raíces tienen un papel fundamental en el funcionamiento de las plantas y las comunidades captando nutrientes y agua del suelo, siendo la principal vía de transferencia de carbono al suelo (Prieto et al. 2015). Por todo esto, se hace imprescindible tratar de abarcar las diferentes dimensiones (a través de los rasgos que las componen) para maximizar nuestra comprensión, tanto de las estrategias que desarrollan las diferentes especies para poder adaptarse a un ambiente determinado, como de los procesos ecosistémicos que tratamos de estudiar (Wright et al 2007; Laughlin 2014).

Es difícil generalizar en algunos aspectos de la ecología funcional, así los estudios que han cuantificado rasgos en diferentes órganos de la planta han mostrado una gran disparidad de resultados. Mientras que algunos trabajos han observado una fuerte coordinación entre rasgos funcionales de distintos órganos relacionados con el espectro de economía (Freschet et al. 2010; Liu et al. 2010; Méndez-Alonzo et al. 2012; Pérez-Ramos et al. 2012; 
Pivovaroff et al. 2014) así como de éstos con otros rasgos relacionados con estrategias competitivas o reproductoras (Reich et al. 1998; Wright et al. 2007), otros estudios han obtenido resultados opuestos tanto en lo relativo a la coordinación de estrategias relacionadas con la adquisición de recursos (Tjoelker et al. 2005; Baraloto et al. 2010; Fortunel et al. 2012) como en la comparación de rasgos entre distintas estrategias (Westoby et al. 1998; Liancourt et al. 2009; Golodets et al. 2009; Laughlin et al. 2010; Silva et al. 2015). Esta disparidad de resultados también se hace patente en lo referente a la diversidad funcional. No hay un consenso sobre cómo varía la diversidad funcional con los gradientes ambientales. Así, en algunos trabajos la diversidad funcional aumenta cuando las condiciones ambientales son más favorables (Lamanna et al. 2014), mientras que otros estudios encuentran valores más altos de diversidad bajo condiciones más limitantes (Mayfield y Levine 2010; Pakeman 2011; de Bello et al. 2013). Este fuerte contraste entre resultados hace muy difícil la generalización de patrones en lo referente a cómo la estructura funcional (p.ej. la composición y diversidad de los rasgos funcionales; Mouillot et al. 2011) de las comunidades vegetales varía a lo largo de gradientes ambientales. El resultado de estas diferencias puede ser debido en gran parte a la comparación de estudios que cuantifican rasgos en especies con diferentes formas de crecimiento así como a lo largo de diferentes escalas espaciales, estando a su vez condicionados dichos resultados a la idiosincrasia propia del ecosistema donde se realice el estudio (Kembel y Cahill 2011).

\subsection{Ensamblaje de comunidades y filtrado ambiental}

Conocer los procesos que gobiernan el ensamblaje de comunidades vegetales es una cuestión fundamental de la ecología, tanto desde un punto de vista teórico como aplicado (Young et al. 2001). Uno de los objetivos claves consiste en predecir qué especies del conjunto total (pool) pueden ocupar un determinado hábitat (Keddy 1992). Así, podemos predecir la estructura y composición de la comunidad considerando: (i) el pool regional existente, que determina a priori qué especies tienen potencialmente la capacidad de colonizar ese determinado hábitat; (ii) las características ambientales (abióticas y bióticas) de ese hábitat que lo hacen adecuado para la colonización de ciertas especies y no de otras, actuando como un filtro ambiental; (iii) y el orden de llegada de los organismos que lo van a colonizar (ver de la Riva et al. 2011 y referencias citadas allí).

La composición y abundancia de las especies vegetales que componen una determinada comunidad varían a lo largo de gradientes ambientales, que pueden apreciarse tanto a nivel local como regional (Whittaker 1956). Esto se debe a que las características intrínsecas de un determinado hábitat actúan como filtro seleccionando a aquellas especies que posean características que les permitan sobrevivir y reproducirse bajo esas condiciones ambientales determinadas (Keddy 1992). Así, podemos decir que la idoneidad de un hábitat para el establecimiento de las especies que van a conformar una determinada comunidad viene determinado por una serie de "filtros" (en sentido amplio): por un lado la adversidad ambiental, como resultado del estrés y las perturbaciones ambientales y, por otro lado, las interacciones bióticas como resultado de procesos de competencia y de facilitación (Geho et al. 2008) o por procesos de herbivoría (Cingolani et al. 2005).

No todas las especies presentes en un determinado hábitat van a tener la misma abundancia (Cingolani et al. 2007); así generalmente las comunidades presentan unas pocas especies más abundantes que dominan la co- 


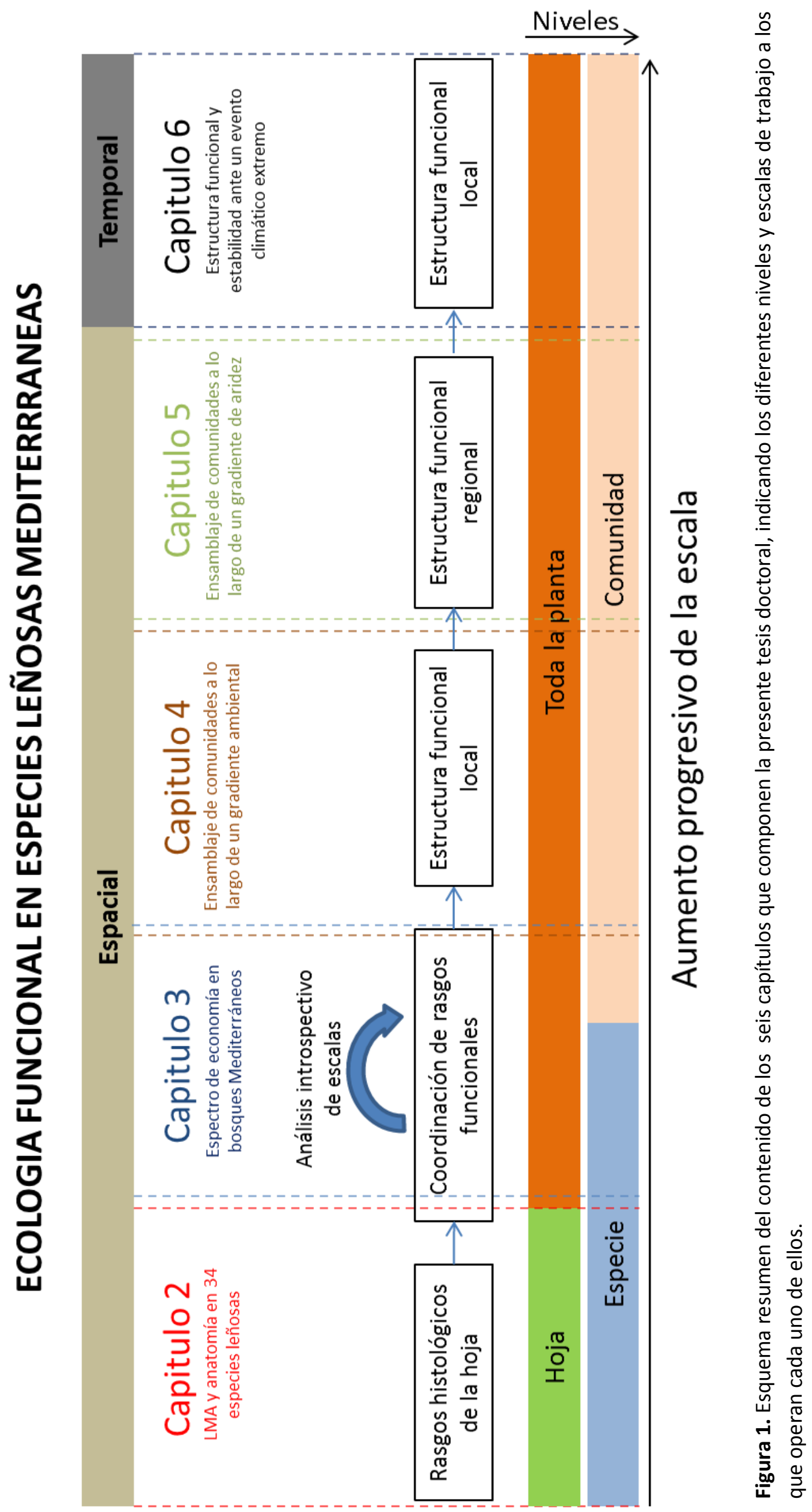


munidad y un grupo mayoritario de especies menos abundantes (Grime 1998). Se han propuesto dos niveles en el proceso de filtrado ambiental (Cingolani et al. 2007): un primer nivel impuesto por las condiciones ambientales que determina qué especies van a ser capaces de persistir en esa comunidad en función de sus rasgos funcionales y tiende a causar similitud entre ellas (convergencia adaptativa); y un segundo nivel que determina qué especies van a ser más dominantes, y que tiende a provocar sobredispersión (divergencia adaptativa) de los rasgos como resultado de la diversificación de nichos (MacArthur y Levins 1967; Weiher et al. 2011). Por ejemplo, en ecosistemas mediterráneos cabría esperarse una mayor dominancia de especies esclerófilas de bajo porte y crecimiento lento en zonas más secas y pobres en nutrientes, mientras que por el contrario en sitios más húmedos abundarían especies caducifolias con tasas más altas de crecimiento y adquisición de recursos (Reich et al. 1998; Wright y Westoby 2001; Villar et al. 2006; Poorter y Garnier 2007).

Así pues, la aproximación funcional juega un papel fundamental en los estudios que pretenden profundizar en el conocimiento de las reglas de ensamblaje de las comunidades, permitiéndonos evaluar las respuestas fisiológicas de las especies y la variación funcional de las mismas como resultado de las condiciones tanto abióticas como bióticas (McGill et al. 2006; Violle et al. 2007). El interés creciente en la aproximación funcional como herramienta clave para entender los mecanismos subyacentes del ensamblaje de comunidades a lo largo de gradientes ambientales se pone de manifiesto por el creciente número de artículos publicados en la última década que utilizan los rasgos funcionales de la comunidad para predecir la distribución de espe-cies a lo largo de ejes ambientales (Laughlin et al. 2011; Frenette-Dussault et al. 2013), así como para comprender el papel que juegan las variables ambientales en la estructura de la comunidad (Suding et al. 2005; Chalcraft et al. 2008; Craine et al. 2012). Estos estudios han sido llevados a cabo ampliamente a escala local (Bernard-Verdier et al. 2012; PérezRamos et al. 2012) y, en menor medida, a escala regional (Lamana et al. 2014) o global (Wright et al. 2004).

\section{Contexto de la tesis en el marco de la ecología funcional}

Los cinco artículos que componen esta Tesis ilustran cómo el enfoque funcional puede ayudarnos a dilucidar la complejidad de los mecanismos ecológicos que operan en los ecosistemas, ayudándonos a su vez a comprender los servicios ecosistémicos subyacentes que prestan los mismos. Como exponíamos al principio de la introducción, para hacer frente a cuestiones científicas y de gestión sobre la prestación de estos servicios, es necesario avanzar en la comprensión funcional a diferentes escalas, tanto dentro de las mismas comunidades (y de los individuos que las componen) como a nivel de las interacciones que se establecen entre diferentes comunidades que componen los servicios de los ecosistemas a mayores escalas espaciales (Lavorel 2013). En este sentido, un aumento del conocimiento basado en la aproximación funcional nos puede ayudar en la gestión dentro del marco de los servicios de los ecosistemas, por ejemplo en el contexto de la restauración ecológica (ver de la Riva et al. 2011) o del cambio global (por ejemplo esta tesis, explícitamente en los capítulos 4, 5 y 6), siendo aún un reto importante y que abre nuevas vías hacia enfoques más genéricos e integrados (Lavorel 2013). 
Una de las finalidades del avance en el conocimiento funcional es poder utilizarlo como una herramienta de gestión, pero como exponíamos en el párrafo anterior, la dificultad de crear generalizaciones hace imprescindible conocer las características intrínsecas de los diferentes ecosistemas sobre los que se quiera trabajar. En este sentido, esta tesis propone interpretar algunos aspectos de la ecología funcional, centrándose específicamente en un único tipo funcional y en un régimen climático concreto: especies leñosas en clima Mediterráneo. Sin embargo, incluso dentro de un mismo grupo funcional, los patrones pueden variar en función de la escala de estudio (Funk y Cornwell 2013). Así pues, esta tesis trata de generalizar y entender los procesos que tienen lugar en las comunidades de leñosas Mediterráneas en condiciones naturales a diferentes niveles (Figura 1). Por un lado, se ha trabajado a lo largo de diferentes escalas que nos ayuden a comprender esos patrones generales (Figura 1) y, por otro lado, se han cuantificado rasgos funcionales a nivel de toda la planta para tratar de abarcar todas las dimensiones posibles y permitirnos maximizar nuestra comprensión de dichos ecosistemas (Laughlin 2014):

- Los dos primeros capítulos (2 y 3) están enfocados a evaluar la coordinación existente entre los diferentes rasgos funcionales a diferentes escalas. En el capítulo 2 se estudian las relaciones entre rasgos histológicos de las hojas, mientras que en el capítulo 3 se abordan las relaciones existentes entre rasgos pertenecientes a diferentes órganos de la planta (hoja, tallo, raíz, semilla y planta entera) tanto a nivel de especie como de comunidad.

- Los siguientes capítulos (4, 5 y 6) se centran principalmente en el uso de rasgos funcionales para tratar de comprender mejor las reglas de ensamblaje de la comunidad, abordando este enfoque desde un punto de vista espacial (explorando gradientes ambientales, tanto a escala local como regional) y temporal (al evaluar el impacto de un evento climático extremo).

\section{Objetivos de la tesis}

El objetivo general de la tesis consiste en entender mejor las estrategias que desarrollan las diferentes especies para persistir en un ambiente determinado así como las reglas que gobiernan el proceso de ensamblaje de las comunidades de plantas leñosas mediterráneas, desde el marco conceptual de la ecología funcional. Para llevar a cabo este objetivo se ha analizado la variación de una serie de rasgos funcionales pertenecientes a diferentes órganos de la planta (hojas, tallos y raíces) en diferentes hábitats localizados a lo largo de amplios gradientes ambientales en el sur de España (Figura 2).

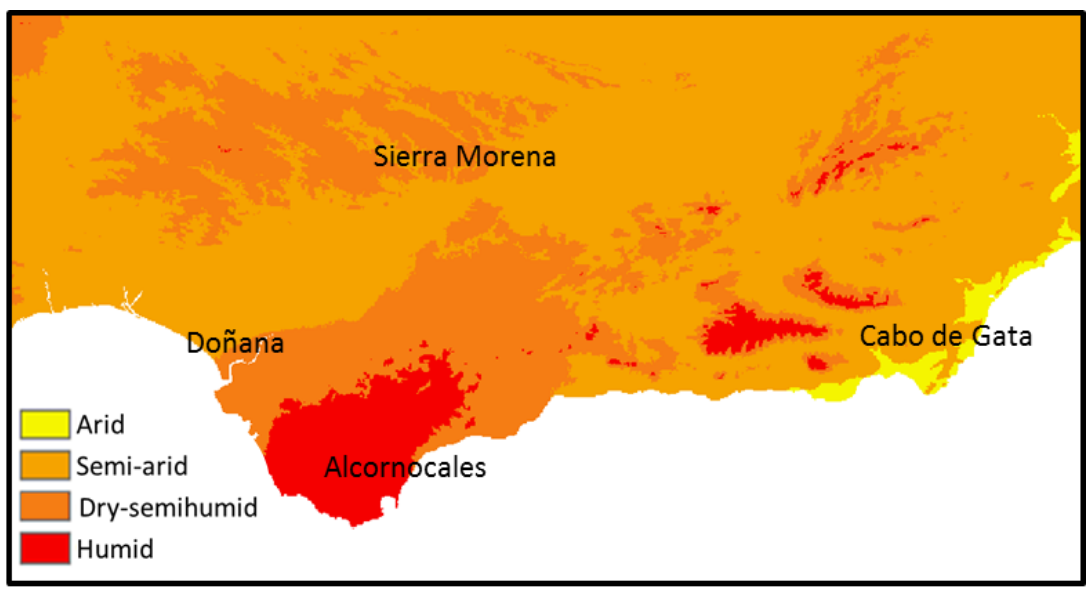

Figura 2. Localización de las cuatro zonas de estudio en la Región de Andalucía. El mapa de aridez ha sido generado con el software ArcGis 10.2 (Trabucco y Zomer, 2009). 
Lo que se propone es forjar una base de conocimiento donde las diferentes comunidades de plantas leñosas y sus atributos sean analizados tanto en conjunto como a través de los componentes que determinan su estructura funcional. Los trabajos de esta tesis se han centrado específicamente en un único tipo vital de planta (life form) - especies leñosas - y en un régimen climático concreto - Mediterráneo -. Sin embargo, los patrones funcionales pueden variar dentro de un mismo tipo de planta en función de la escala espacial de estudio (Funk y Cornwell 2013). Así, los objetivos principales de la tesis son: (i) analizar la variación de la estructura funcional y los mecanismos de ensamblaje de las comunidades de especies leñosas mediterráneas a diferentes escalas; (ii) analizar las estrategias funcionales tanto a nivel de especie como de comunidad a lo largo de gradientes ambientales. Específicamente, los objetivos de cada capítulo son los siguientes:

En el capítulo 2: (i) comprender en qué medida el grosor o la densidad de la hoja determinan la biomasa por unidad de área (LMA) y cómo se relacionan estos rasgos funcionales con los tejidos anatómicos; (ii) determinar cómo los componentes químicos se relacionan con los rasgos anatómicos y estructurales de la hoja; y (iii) entender cómo la disponibilidad de agua en el suelo condiciona la selección de especies con determinados rasgos foliares (tanto anatómicos como estructurales).

En el capítulo 3: (i) determinar si existe o no coordinación entre los rasgos funcionales de diferentes órganos (hoja, tallo y raíz) en 38 especies leñosas seleccionadas a lo largo de un gradiente ambiental local, así como comprobar si el patrón obtenido a lo largo del gradiente se mantiene en las especies que cohabitan en condiciones ambientales similares dentro del gradiente; (ii) determinar si los rasgos asociados con la estrategia adquisitiva de recursos se relacionan con rasgos asociados con otras estrategias, como competencia (altura) o establecimiento (peso de semilla); y (iii) testar si las relaciones obtenidas a nivel de especie se mantienen a nivel de comunidad.

En el capítulo 4: (i) identificar los factores ambientales del suelo (disponibilidad de agua y nutrientes) que condicionan la distribución de especies y, por ende, la variación funcional de las comunidades a lo largo de un gradiente ambiental local; (ii) cuantificar qué mecanismos (reemplazo de especies, cambios de dominancia o variación intraespecífica) determinan la variación de la estructura funcional de la comunidad a lo largo de dichos gradientes.

En el capítulo 5: (i) entender en qué medida las estructura funcional (a nivel de toda la planta) de diferentes comunidades es sensible al gradiente de aridez; (ii) analizar la variación del nicho funcional a lo largo del gradiente; (iii) verificar si los patrones obtenidos a nivel de toda la planta se mantienen para las diferentes dimensiones, o si por el contrario el espacio funcional depende de la dimensión analizada.

En el capítulo 6: (i) determinar qué características funcionales a nivel de comunidad se relacionan con la resistencia y/o resiliencia de dicha comunidad ante un evento climático extremo, y como la diversidad funcional está relacionada con la resistencia y/o resiliencia de la comunidad; y (ii) determinar la importancia de los patrones de regeneración en el mantenimiento de la estructura funcional tras la perturbación. 


\section{Aspectos más relevantes de la tesis}

Los aspectos más relevantes de esta tesis se pueden separar en cinco apartados:

I. Exploración de una ingente cantidad de rasgos funcionales. En los diferentes capítulos de esta tesis se realizó un enorme esfuerzo por cuantificar un amplio espectro de rasgos vegetales, relacionados con las diferentes dimensiones de la planta. Son de destacar especialmente los rasgos funcionales cuantificados a nivel de raíz, dado el limitado número de estudios de especies leñosas (en condiciones de campo, por su dificultad) que han tenido en cuenta esta componente subterránea de la comunidad vegetal, especialmente a escala regional.

II. Exploración de rasgos funcionales en condiciones naturales. Todos los rasgos funcionales se han medido en individuos adultos desarrollados en condiciones naturales, lo que por un lado nos aporta un valor realista de la adaptación de cada especie a ese ambiente determinado y, por otro, nos permite tener en consideración la variabilidad intraespecífica en cada comunidad estudiada.

III. La aplicación de un nuevo método para caracterizar la variación de la estructura funcional. Específicamente en el capítulo 3 se propone un nuevo método cuantitativo que nos ayuda a comprender mejor qué mecanismos tienen lugar en el cambio de la estructura funcional de las comunidades a lo largo de gradientes ambientales. Este método permite diferenciar si la variación funcional entre comunidades a lo largo de un determinado gradiente ambiental proviene principalmente de la variación intraespecífica de dichas especies, de cambios en las abundancias de las mismas o del reemplazo de especies.

IV. Elevada representatividad de la muestra. En la presente tesis se han explorado un elevado número tanto de especies leñosas mediterráneas como de individuos. Así, a lo largo de los diferentes estudios que componen esta tesis se han estudiado un total de 80 especies leñosas. Gran parte de estas especies se han muestreado en más de una zona, sumando un total de 768 individuos para los rasgos foliares y 512 para los radiculares, además de 1280 para los rasgos relativos al tamaño de la planta.

V. Uso de diferentes escalas y niveles jerárquicos. A lo largo de la tesis se ha tratado de abordar el análisis de las comunidades leñosas mediterráneas a diferentes escalas de estudio: (i) a nivel espacial, local - capitulo 4 - y regional - capítulo 5 -; (ii) a nivel temporal, al analizar la respuesta de la comunidad de plantas ante un evento climático extremo en diferentes tiempos (tanto antes de la perturbación como dos y ocho años después de ella; véanse detalles en capítulo 6); y (iii) a diferentes niveles jerárquicos (desde la hoja hasta la comunidad). 


\section{Bibliografía}

Baraloto C, Paine CE, Poorter L., Beauchene J, Bonal D, Domenach AM, Hérault B, Patiño S, Roggy JC, Chave J (2010). Decoupled leaf and stem economics in rain forest trees. Ecology Letters, 13: 1338-1347.

Bernard-Verdier M, Navas ML, Vellend M, Violle C, Fayolle A, Garnier E (2012). Community assembly along a soil depth gradient: contrasting patterns of plant trait convergence and divergence in a Mediterranean rangeland. Journal of Ecology, 100: 1422-1433.

Blonder B, Lamanna C, Violle C, Enquist BJ (2014). The n-dimensional hypervolume. Global Ecology and Biogeography, 23: 595609.

Cardinale B J, Palmer MA, Collins S L (2002). Species diversity enhances ecosystem functioning through interspecific facilitation. Nature, 415: 426-429.

Chalcraft DR, Cox SB, Clark C, Cleland EE, Suding KN, Weiher E, Pennington D (2008). Scale-dependent responses of plant biodiversity to nitrogen enrichment. Ecology, 89:2165-2171.

Chapin FS III, Zavaleta ES, Eviner VT, Naylor RL, Vitousek PM, Reynolds HL, Hooper DU, Lavorel S, Sala OE, Hobbie SE, Mack MC, Díaz S (2000). Consequences of changing biodiversity. Nature, 405: 234-242.

Chase JM, Leibold MA (2003). Ecological Niches: Linking Classical and Contemporary Approaches, University of Chicago Press.

Cingolani AM, Cabido M, Gurvich DE, Renison D, Díaz S (2007). Filtering processes in the assembly of plant communities: are species presence and abundance driven by the same traits? Journal of Vegetation Science, 18: 911-920.

Cingolani AM, Posse G, Collantes MB (2005). Plant functional traits, herbivore selectivity and response to sheep grazing in Patagonian steppe grasslands. Journal of Applied Ecology, 42: 50-59.

Craine JM, Towne EG, Ocheltree TW, Nippert JB (2012). Community trait scape of foliar nitrogen isotopes reveals N availability patterns in a tallgrass prairie. Plant and soil, 356: 395-403.

de Bello FD, Lavorel S, Lavergne S, Albert CH, Boulangeat I, Mazel F, Thuiller W (2013). Hierarchical effects of environmental filters on the functional structure of plant communities: a case study in the French Alps. Ecography, 36: 393-402.

de la Riva EG, Casado MA, Jiménez MD, Mola I, Costa-Tenorio M, Balaguer L (2011). Rates of local colonization and extinction reveal different plant community assembly mechanisms on road verges in central Spain. Journal of Vegetation Science, 22: $292-302$.

de la Riva EG, Pérez-Ramos I, Fernández CN, Olmo M, Marañon T, Villar R (2014). Rasgos funcionales en el género Quercus: estrategias adquisitivas frente a conservativas en el uso de recursos. Ecosistemas ,23: 82-89.

Díaz S, Cabido M (2001). Vive la difference: plant functional diversity matters to ecosystem processes. Trends in Ecology \& Evolution, 16: 646-655.

Díaz S, Hodgson JG, Thompson K, Cabido M, et al. (2004). The plant traits that drive ecosystems: evidence from three continents. Journal of Vegetation Science, 15: 295- 304.

Escudero A, Valladares F (2016). Trait-based plant ecology: moving towards a unifying species coexistence theory. Oecologia, 1-4.

Fortunel C, Fine PV, Baraloto C (2012). Leaf, stem and root tissue strategies across 758 Neotropical tree species. Functional Ecology ,26: 1153-1161.

Frenette-Dussault C, Shipley B, Meziane D, Hingrats Y (2012). Functional structure of an arid steppe plant community reveals similarities with Grime's CSR theory. Journal of Vegetation Science, 23: 208-222.

Freschet GT, Cornelissen JHC, van Logtestijn RSP, Aerts R (2010). Evidence of the "plant economics spectrum" in a subarctic flora. Journal of Ecology, 98: 362-373.

Funk JL, Cornwell WK (2013). Leaf traits within communities: context may affect the mapping of traits to function. Ecology, 94 : 1893-1897. 
Garnier E, Navas ML (2012). A trait-based approach to comparative functional plant ecology: concepts, methods and applications for agroecology. Agronomy for Sustainable Development, 32: 365-399.

Golodets C, Sternberg M, Kigel J (2009). A community level test of the leaf height seed ecology strategy scheme in relation to grazing conditions. Journal of Vegetation Science, 20: 392-402.

Grime JP (1998). Benefits of plant diversity to ecosystems: immediate, filter and founder effects. Journal of Ecology, 86: 902910.

Grime JP (1977). Evidence for the existence of three primary strategies in plants and its relevance to ecological and evolutionary theory. American Naturalist, 111: 1169-1194.

Grover JP (1997) Resource Competition. Population and community ecology series 19.

Heberling JM,Fridley JD (2012). Biogeographic constraints on the world-wide leaf economics spectrum. Global Ecology and Biogeography, 21: 1137-1146.

Holdaway RJ, Richardson SJ, Dickie IA, Peltzer DA, Coomes DA (2011). Species- and community-level changes in fi ne root traits along a 120000 year soil chronosequence in New Zealand. Journal of Ecology, 99: 954 - 963.

Hooper DU, Vitousek PM (1997). The effects of plant composition and diversity on ecosystem processes. Science, 277 : $1302-$ 1305.

Hutchinson GE (1957). Cold Spring Harbour Symposium on Quantitative Biology. Concluding remarks, 22: $415-427$.

Keddy PA (1992). Assembly and response rules: two goals for predictive community ecology. Journal of Vegetation Science, 3: 157-164.

Kembel SW, Cahill Jr JF (2011). Independent evolution of leaf and root traits within and among temperate grassland plant communities. PloS one, 6: e19992.

Lamanna C, Blonder B, Violle C, et al. (2014). Functional trait space and the latitudinal diversity gradient. Proceedings of the National Academy of Sciences, 111: 13745-13750.

Lande R (1996). Statistics and partitioning of species diversity, and similarity among multiple communities. Oikos, 76: 5-13.

Laughlin DC (2014). The intrinsic dimensionality of plant traits and its relevance to community assembly. Journal of Ecology, 102: 186-193.

Laughlin DC (2011). Nitrification is linked to dominant leaf traits rather than functional diversity. Journal of Ecology, 99: 10911099.

Laughlin DC, Leppert JJ, Moore MM, Sieg CH (2010). A multi-trait test of the leaf-height-seed plant strategy scheme with 133 species from a pine forest flora. Functional Ecology, 24: 493-501

Lavorel S (2013). Plant functional effects on ecosystem services. Journal of Ecology, 101: 4-8.

Lavorel S, Garnier E (2002). Predicting changes in community composition and ecosystem functioning from plant traits: revisiting the Holy Grail. Functional ecology, 16: 545-556.

Lavorel S, Grigulis K, McIntyre S, et al. (2008). Assessing functional diversity in the field-methodology matters! Functional Ecology, 22: 134-147.

Liancourt P, Tielborger K, Bangerter S, Prasse R (2009). Components of 'competitive ability' in the LHSmodel: implication on coexistence for twelve co-occurring Mediterranean grasses. Basic and Applied Ecology, 10: 707-714.

Liu G, Freschet GT, Pan X, Cornelissen JHC, Li Y, Dong M (2010). Coordinated variation in leaf and root traits across multiple spatial scales in Chinese semi-arid and arid ecosystems. NewPhytologist, 188: 543-553.

Loreau M (1998). Biodiversity and ecosystem functioning: a mechanistic. Proceedings of the National Academy of SciencesUSA, 95: 5632- 5636.

MacArthur RH, Levins R (1967). The limiting similarity, convergence and divergence of coexisting species. American Naturalist, 101: 377-385. 
Mason NW, Mouillot D, Lee WG, Wilson JB (2005). Functional richness, functional evenness and functional divergence: the primary components of functional diversity. Oikos, 111: 112-118.

May RM (1981). Patterns in multi-species communities. In Theoretical Ecology: Principles and Applications (2nd edn) (May,R.M., ed.), pp. 197-227, Blackwell Scientific.

Mayfield MM, Levine JM (2010). Opposing effects of competitive exclusion on the phylogenetic structure of communities. Ecology letters, 13: 1085-1093.

McGill BJ, Enquist BJ, Weiher E, Westoby M (2006). Rebuilding community ecology from functional traits. Trends Ecolology and Evolution, 21: $178-185$.

Méndez-Alonzo R, Paz H, Zuluaga RC, Rosell JA, Olson ME (2012). Coordinated evolution of leaf and stem economics in tropical dry forest trees. Ecology, 93: 2397-2406.

Millennium Ecosystem Assessment (2005) Ecosystems and Human Well-Being: Synthesis. Island Press, Washington, DC, USA.

Mouillot D, Villéger S, Scherer-Lorenzen M, Mason NW (2011). Functional structure of biological communities predicts ecosystem multifunctionality. PloS one, 6:e17476.

Mulder CPH, Uliassi DD, Doak DF (2001). Physical stress and diversity-productivity relationships: the role of positive interactions. Proceedings of the National Academy of Sciences, 98:6704-6708.

Noble IR,Slatyer RO (1980). The use of vital attributes to predict successional changes in plant communities subject to recurrent disturbances. Vegetatio, 43: 5-21.

Pakeman RJ (2011). Functional diversity indices reveal the impacts of land use intensification on plant community assembly. Journal of Ecology, 99: 1143-1151.

Pérez-Ramos, IM, Roumet C, Cruz P, Blanchard A, Autran P, Garnier E (2012). Evidence for a "plant community eco-nomics spectrum" driven by nutrient and water limitations in aMediterranean rangeland of southern France. Journal of Ecology, 100: 1315-1327.

Petchey OL, Gaston KJ (2006). Functional diversity: back to basics and looking forward. Ecology letters, 9: $741-758$.

Pivovaroff AL, Sack L, Santiago LS (2014). Coordination of stem and leaf hydraulic conductance in southern California shrubs: a test of the hydraulic segmentation hypothesis. New Phytologist, 302: 842-850.

Poorter H, Garnier E (2007). Ecological significance of inherent variation in relative growth rate and its compo- nents. In: Punnaire, Fl, Valladares F (eds.) Functional Plant Ecology, 2nd edn, pp. 67-100. CRC Press, Boca Raton, FL, US.

Prieto I, Roumet C, Cardinael R, et al. (2015). Root functional parameters along a land-use gradient: evidence of a communitylevel economics spectrum. Journal of Ecology, 103: 361-373.

Raunkiaer C (1934). The life forms of plants and statistical plant geography; being the collected papers of C. Raunkiaer. Clarendon Press, Oxford.

Reich PB, Walters MB, Tjoelker MG, Vanderklein D, Buschena C (1998). Photosynthesis and respiration rates depend on leaf and root morphology and nitrogen concentration in nine boreal tree species differing in relative growth rate. Functional Ecology, 12: 395-405.

Sack L, Scoffoni C, John GP, Poorter H, Mason CM, Mendez-Alonzo R, Donovan LA (2013). How do leaf veins influence the worldwide leaf economic spectrum? Review and synthesis. Journal of Experimental Botany, 64: 4053-4080.

Schleuter D, Daufresne M, Massol F, Argillier C (2010). A user's guide to functional diversity indices. Ecological Monographs, 80: 469-484.

Silva MAM, Pinto ADVF, do Nascimento LM, Lins-e-Silva ACB, de Lima ALA, Rodal MJN (2015). Does the plant economics spectrum change with secondary succession in the forest? Trees, 29: 1521-1531.

Silvertown J, Franco M,McConway K (1992). A demographic interpretation of Grime's triangle. Functional Ecology, 6: 130-136. 
Suding KN, Collins SL, Gough L, et al. (2005). Functional-and abundance-based mechanisms explain diversity loss due to N fertilization. Proceedings of the National Academy of Sciences of the USA, 102: 4387-4392.

Suding KN, Lavorel S, Chapin FS, et al. (2008). Scaling environmental change through the community-level: a trait-based response-and-effect framework for plants. Global Change Biology, 14: 1125-1140.

Tilman D (2001). Functional diversity. In: Levin, S. A. (ed.), Encyclopedia of biodiversity. Academic Press, pp. 109-120.

Tilman D, Knops J, Wedin D, Reich P, Ritchie M, Siemann E (1997). The influence of functional diversity and composition on ecosystem processes. Science, 277: 1300-1302.

TjoelkerMG, Craine JM, Wedin D, Reich PB, Tilman D (2005). Linking leaf and root trait syndromes among 39 grass- land and savannah species. New Phytologist, 167: 493-508.

Trabucco A, Zomer RJ (2009). Global Aridity Index (Global-Aridity) and Global Potential Evapo-Transpiration (Global-PET) Geospatial Database. CGIAR Consortium for Spatial Information. Published online, available from the CGIAR-CSI GeoPortal at: http://www.csi.cgiar.org

Villar R, Robleto JR, De Jong Y, Poorter H (2006). Differences in construction costs and chemical composition between deciduous and evergreen woody species are small as compared to differences among families. Plant, Cell and Environment, 29: 1629-1643.

Villéger S, Mason NW, Mouillot D (2008). New multidimensional functional diversity indices for a multifaceted framework in functional ecology. Ecology, 89: 2290-2301.

Villéger S, Miranda JR, Hernández DF, Mouillot D (2010). Contrasting changes in taxonomic vs. functional diversity of tropical fish communities after habitat degradation. Ecological Applications, 20: 1512-1522.

Violle C, Navas ML, Vile D, Kazakou E, Fortunel C, Hummel I, Garnier E (2007). Let the concept of trait be functional! Oikos, 116: 882-892.

Weiher E (2011). A primer of trait and functional diversity. Biological diversity: frontiers in measurement and assessment, 175193.

Westoby M (1998). A leaf-height-seed (LHS) plant ecology strategy scheme. Plant and Soil, 199: 213-227.

Whittaker RJ (1975). Communities and ecosystems. Macmillan, New York.

Wright IJ, Ackerly DD, Bongers, F., et al. (2007). Relationships among ecologically important dimensions of plant trait variation in seven neotropical forests. Annals of Botany, 99: 1003-1015.

Wright IJ,Westoby M (2001). Understanding seedling growth relationships through specific leaf area and leaf nitrogen concentration: generalisations across growth forms and growth irradiance. Oecologia, 127: 21-29.

Wright IJ, Reich PB, Cornelissen JH, et al. (2005). Modulation of leaf economic traits and trait relationships by climate. Global Ecology and Biogeography, 14: 411-421.

Wright IJ, Reich PB, Westoby M, et al. (2004). The worldwide leaf economics spectrum. Nature, 428: 821-827.

Yodzis P (1978). Competition for Space and the Structure of Ecological Communities, Springer-Verlag.

Young TP, Chase JM, Huddleston RT (2001). Community succession and assembly: comparing, contrasting and combining paradigms in the context of ecological restoration. Ecological Restoration, 19: 5-18. 


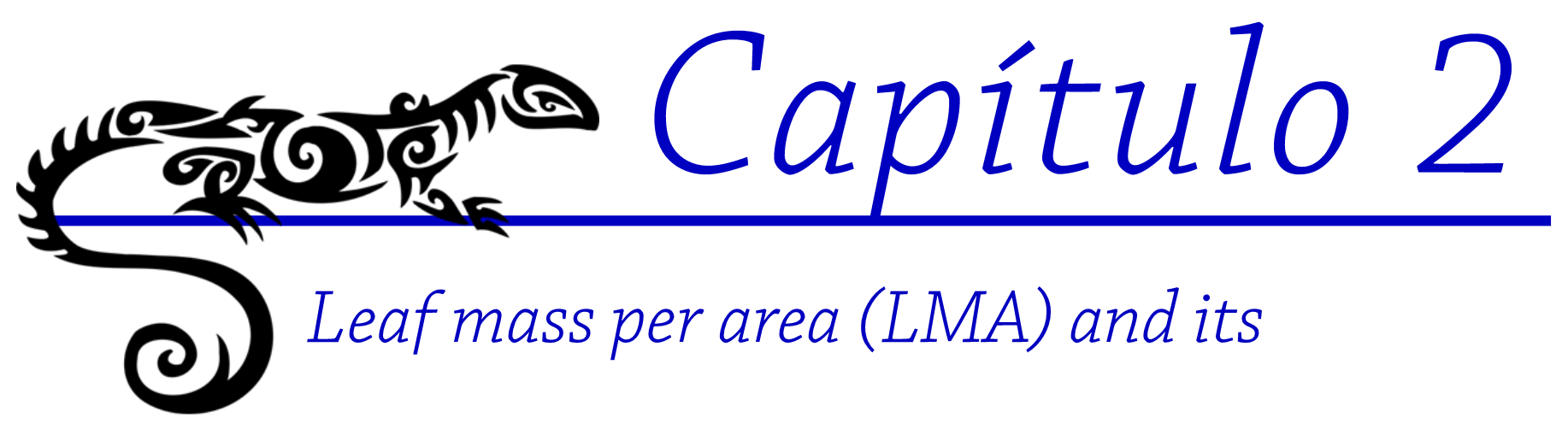

relation with leaf structure and anatomy in 34

Mediterranean woody secies along a water availability gradient

"He aqui mi secreta, que na puede ser más simple... lo esencial es invisible para los ajos" El Principito (Antoine de Saint-Exupéry)

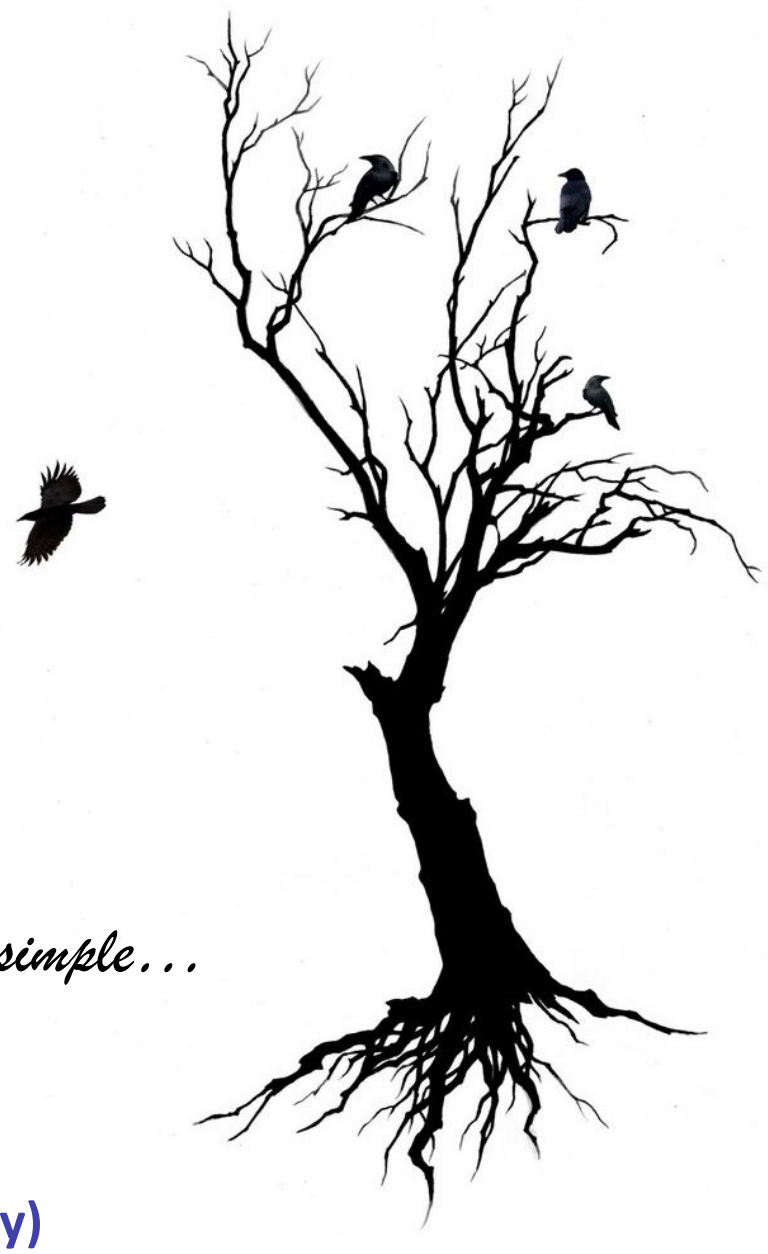





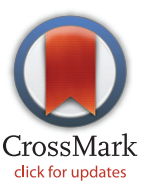

\section{G openaccess}

Citation: de la Riva EG, Olmo M, Poorter H, Ubera JL, Villar R (2016) Leaf Mass per Area (LMA) and Its Relationship with Leaf Structure and Anatomy in 34 Mediterranean Woody Species along a Water Availability Gradient. PLOS ONE 11(2): e0148788. doi:10.1371/journal.pone.0148788

Editor: Cristina Armas, Estacion Experimental de Zonas Aridas - CSIC, SPAIN

Received: August 24, 2015

Accepted: January 22, 2016

Published: February 11, 2016

Copyright: @ 2016 de la Riva et al. This is an open access article distributed under the terms of the Creative Commons Attribution License, which permits unrestricted use, distribution, and reproduction in any medium, provided the original author and source are credited.

Data Availability Statement: Data are available in Supporting Information

Funding: This study was funded by the Spanish MEC coordinated project DIVERBOS (CGL201130285-C02-01 and C02-02), ECO-MEDIT (CGL201453236-R), the Andalusian ANASINQUE project (PGC2010-RNM-5782), the Life + Biodehesa Project (11/BIO/ES/000726), and European FEDER funds.

Competing Interests: The authors have declared that no competing interests exist.
RESEARCH ARTICLE

\section{Leaf Mass per Area (LMA) and Its Relationship with Leaf Structure and Anatomy in 34 Mediterranean Woody Species along a Water Availability Gradient}

\author{
Enrique G. de la Riva ${ }^{1}$, Manuel Olmo ${ }^{1}$, Hendrik Poorter ${ }^{2}$, José Luis Ubera ${ }^{3}$, Rafael Villar ${ }^{1}$ * \\ 1 Area de Ecología, Facultad de Ciencias, Universidad de Córdoba, 14071 Córdoba, Spain, 2 Plant \\ Sciences (IBG-2), Forschungszentrum Jülich GmbH, 52425 Jülich, Germany, 3 Area de Botánica, Facultad \\ de Ciencias, Universidad de Córdoba, 14071 Córdoba, Spain \\ * rafael.villar@uco.es
}

\section{Abstract}

Leaf mass per area (LMA) is a morphological trait widely used as a good indicator of plant functioning (i.e. photosynthetic and respiratory rates, chemical composition, resistance to herbivory, etc.). The LMA can be broken down into the leaf density (LD) and leaf volume to area ratio (LVA or thickness), which in turn are determined by anatomical tissues and chemical composition. The aim of this study is to understand the anatomical and chemical characteristics related to LMA variation in species growing in the field along a water availability gradient. We determined LMA and its components (LD, LVA and anatomical tissues) for 34 Mediterranean (20 evergreen and 14 deciduous) woody species. Variation in LMA was due to variation in both LD and LVA. For both deciduous and evergreen species LVA variation was strongly and positively related with mesophyll volume per area (VA or thickness), but for evergreen species positive relationships of LVA with the VA of epidermis, vascular plus sclerenchyma tissues and air spaces were found as well. The leaf carbon concentration was positively related with mesophyll VA in deciduous species, and with VA of vascular plus sclerenchymatic tissues in evergreens. Species occurring at the sites with lower water availability were generally characterised by a high LMA and LD.

\section{Introduction}

Plant traits can determine species differences in productivity and performance and therefore the distribution of species in nature [1-5]. In this regard, leaf traits are fundamental for ecosystem functioning, being related with important processes such as carbon gain or litter decomposability $[1,4,6,7]$. One of the central variables among the leaf traits is the leaf mass per area (LMA), which is the ratio between leaf dry mass and leaf area $[6,8]$. In spite of being a morphological trait, LMA (or its inverse, specific leaf area, SLA) is highly correlated with leaf processes such as maximum photosynthetic rate $[1,9,10,11]$, whole-plant activities such as the species' 
potential growth rate [12-15] and ecosystem processes such as decomposition rate [7, 16, 17]. The LMA of a species is therefore a good indicator of the position of that species along an axis based on resources acquisition (Leaf Economic Spectrum) [1]. However, despite its physiological and ecological relevance, the traits which underlie the interspecific variation in LMA are still poorly understood $[6,18]$.

In its simplest form, LMA can be broken down into the product of leaf density (LD, $\mathrm{g} \mathrm{mL}^{-1}$ ) and the leaf volume to area ratio (LVA, $\mathrm{mL} \mathrm{m}^{-2}$, also called leaf thickness) $[8,19]$ :

$$
\operatorname{LMA}\left(\mathrm{g} \mathrm{m}^{-2}\right)=\operatorname{LVA}\left(m L \mathrm{~m}^{-2}\right) \times L D\left(g m L^{-1}\right)
$$

The relative importance of the two variables in explaining variation in LMA is not consistent. Thus, while some studies [20-23] found that LD was the main component that differed between low- and high-LMA species, another study [24] found that variation in LMA was mainly due to variation in LVA. Villar et al. [18] and Niinemets [25] found that LMA variation depended equally on LVA and LD, but the class difference between deciduous and evergreen species was mainly determined by LVA, whereas variation within each group was largely due to density. Also, the relationships between LVA and LD are variable; they have been reported to be negatively correlated [26], but they may also vary independently [22]. These contradictory results suggest that the causes of LMA variation do not necessarily follow a global pattern, and depend on the nature of the species compared and their environment $[6,22,27]$. In order to obtain better insight into this variability, we need more studies testing the relationship between LMA and its two components (LVA and LD), especially for plants growing under natural conditions with diverse species pools in different environments.

The second step towards understanding LMA variation is to consider the different anatomical tissues that shape the leaves. Both LVA and LD are determined by the composition of the different anatomical tissues: epidermis, mesophyll and vascular plus sclerenchymatic tissue, as well as air spaces. The LVA is the sum of the volumes of all the tissues per unit leaf area (VA) plus the air spaces $[6,18]$. The VA of each tissue is often described as "tissue thickness" $(\mu \mathrm{m})$, but as this is technically incorrect for non-laminar tissues such as sclerenchyma, or for air spaces, we will use VA throughout this paper. The other component, LD, is the sum of the densities of each tissue, weighted by the volumetric fraction of that tissue $[6,18]$. The various anatomical tissues generally have different physiological functions: mesophyll is related to photosynthesis and transpiration [28] and air spaces can potentially determine gas exchange variables [29]. So, different combinations of the number and layering of these tissues will have different physiological consequences. Differences in the anatomical composition of the leaves would then affect LVA and LD, and consequently leaf functioning.

Another consequence of variation in the composition of the anatomical tissues is that it may also affect the chemical composition; for example, a high presence of vascular and sclerenchymatic tissue may cause a high $\mathrm{C}$ concentration in the leaf, whereas a large presence of mesophyll may increase the concentration of $\mathrm{N}[6,20,30,31]$. Both $\mathrm{C}$ and $\mathrm{N}$ concentration are strongly related to plant functioning as well $[1,4,5,6]$.

To understand the functional consequences of variation in plant traits or anatomical components, we need more insight into the performance of plants under different environmental conditions [8]. Thus, for example, in habitats with high irradiance and low water availability, such as Mediterranean environments, most species have sclerophyllous evergreen leaves with high LMA, low nutrient concentrations and low maximum photosynthetic rate [10-12, 3234]. Light and water therefore exert an important effect, selecting those species capable of growing and reproducing under such environmental conditions. In relation to this, several studies have found that species with high LMA often occur in areas with low rainfall and high 
temperature and radiation $[1,34,35]$. However, how LVA and LD or leaf anatomy explain LMA variation remains largely unexplored along natural environmental gradients (but see Witkowski and Lamont [8] and Niinemets [34]).

In this study, we explored the variation in LMA and its components (both morphological and anatomical) for 34 Mediterranean (20 evergreen and 14 deciduous) woody species growing along a local environmental gradient, which differed mainly in water availability (see de la Riva et al. [36]). We asked the following questions:

1. To what extent do LVA and LD explain the interspecific variation in LMA?

2. How does variation in the different leaf anatomical tissues explain the differences in LVA, LD and LMA?

3. Are the differences in chemical composition ( $\mathrm{C}$ and $\mathrm{N}$ concentrations) related to the leaf anatomy and morphology (LMA, LVA and LD)?

4. What influence does the soil water gradient exert on leaf traits (structural and anatomical)?

We analysed these questions at two levels: a) considering all the species together and b) at the level of functional groups (within deciduous species or within evergreens). With this approach, we wanted to find general or particular patterns, depending on the group of species considered.

\section{Materials and Methods}

\section{Site characterisation and species selection}

The study was conducted in a Mediterranean habitat with forests and shrublands, located in the Sierra Morena mountains, in the south of Spain. The area is characterised by a continentalMediterranean climate with cold, wet winters and dry, warm summers. The mean annual temperature is $17.6^{\circ} \mathrm{C}$ and the mean annual precipitation is $536 \mathrm{~mm}$, of which $94 \%$ falls from October to June [data from AEMET (Agencia Estatal de Meteorología, Spain) for the 1971-2000 period]. The bedrock is formed by a siliceous substratum, which produces neutral or slightly acid soils (Leptosols). Several shrub species-such as Cistus albidus, Quercus coccifera and Rosmarinus officinalis-are abundant at exposed sites on drier and shallow soils, while broadleaf deciduous trees-such as Alnus glutinosa, Celtis australis, Fraxinus angustifolia and Ulmus minor-are dominant at wetter sites with deeper soils (see S1 Table). Nine sampling sites were selected along the environmental gradient, from ridges to valley bottoms, with the aim of spanning a broad range of soil resource availabilities, mainly for water but also for nutrients. There was no climatic difference across the gradient (see de la Riva et al. [36] for more details) and the differences in water availability were due not to differences in annual rainfall but to the topography (S2 Table). For ease of reference, we will refer to this as a water gradient in most of the text. For trait measurements (see details below), we selected the most abundant woody species (see de la Riva et al. [36], S1 Table). This made a total of 34 selected species (20 evergreen and 14 deciduous species). In late spring (June 2012), during the peak of plant growth, six healthy adults of the most dominant woody plant species were randomly selected for measurement of leaf traits. A few species could be found at several sites, but most were found at only one or two. As our aim was not to analyse the intraspecific variation in leaf traits, we only selected one site for each species.

\section{Leaf measurements}

Leaf samples were collected mainly in private orchards, with the permission of the land owners. The field studies did not involve any endangered or protected species. A few branches with 
young, fully expanded leaves were collected from each selected individual plant. These branches were stored in plastic bags to prevent water loss and were transported to the laboratory, where they were maintained for $24 \mathrm{~h}$ in darkness with the basal portion of their stem submerged in water at $10^{\circ} \mathrm{C}$ to allow complete re-hydration $[37,38]$. Subsequently, a subsample of the leaves was scanned and dried in an oven at $70^{\circ} \mathrm{C}$ for at least $48 \mathrm{~h}$, after which they were weighed to obtain their dry mass. Leaf area was calculated with the Image Pro-Plus v4.5 software (Media Cybernetics, MD, USA). The leaves were then ground with a stainless steel mill, and the $\mathrm{N}$ and $\mathrm{C}$ concentrations measured using an elemental analyser (Eurovector EA 3000; EuroVector SpA, Milan, Italy).

Another subsample was used for anatomical analysis. One healthy leaf of three individuals (from those selected for LMA measurements) per species was selected. From the middle part of the leaves, 5-mm-wide pieces were taken and directly fixed in formaldehyde-acetic acid (FAA; $35-40 \%$ formaldehyde, $70 \%$ ethanol and $100 \%$ acetic acid, $1: 8: 1 \mathrm{v} / \mathrm{v})$. The leaf sections were dehydrated with a series of progressively increasing ethanol concentrations, starting at 50\% and ending at 100\%. They were then embedded using a JB-4 embedding kit (Polysciences Ltd., Warrington, PA, USA); subsequently, 3- $\mu$ m-thick slices were cut by a microtome (Leica Reichert-Jung Autocut 2055 microtome, Wetzlar, Germany) and these were stained with Toluidine blue (5\%). Photographic images were taken via a light microscope, using a Nikon D700 camera. The total area of each cross-section was determined using the image analysis procedures of Adobe Photoshop CS3 (Adobe Systems Inc., San Jose, CA). Two subsamples for each cross-section and individual were selected for measurement of the area occupied by the upper and lower epidermis, the palisade and spongy parenchyma, the vascular and sclerenchymatic tissue and the air spaces (see S1 Fig for the cross-sections of the 34 species). We also measured the leaf thickness in 10 random places for each cross-section of the leaf.

The mean values of all the anatomical measurements were calculated per leaf, and subsequently averaged for each species. The mean values of each tissue were expressed in two ways: the absolute volume of each tissue per unit leaf area (VA, also denoted as the thickness of each tissue) and the volume fraction (percentage of the leaf section occupied by the different tissues and air spaces). Most studies have only determined the volume fractions, but we decided to use both parameters as they answer different questions. The absolute values are employed in order to determine the contribution of each tissue to the LVA (leaf thickness), whereas the volume fractions are analysed in relation to LD. For simplicity in the presentation of the results, we consider: 1) epidermis (upper and lower epidermis), 2) mesophyll (palisade and spongy parenchyma), 3) vascular and sclerenchymatic tissue and 4) the air spaces.

\section{Soil water measurements}

In May 2012, for each site, eight soil samples were taken using an auger, to a maximum depth of one meter. The soil water content was quantified by the gravimetric method, weighing the soil samples when fresh and after oven-drying at $100^{\circ} \mathrm{C}$ for $48 \mathrm{~h}$. From these measurements, we calculated an integrative variable of the whole soil profile for each sample (soil water content, SWC) as: (fresh soil mass-dry soil mass)/ area of the auger section $\left(5 \mathrm{~cm}^{2}\right)$. The soil water content $\left(\mathrm{L} \mathrm{m}^{-2}\right)$ for each sample site was the average of these eight samples.

\section{Data and statistical analysis}

The LMA was calculated as the ratio of leaf dry mass and leaf area. The LD was calculated as the ratio of LMA and LVA (leaf thickness) [8]. The relationships among morphological (LMA, LVA and LD) and anatomical (epidermis, mesophyll, vascular plus sclerenchyma and air spaces) traits were determined by linear regressions, similar to Castro-Díez et al. [22]. 
However, in these regressions one fraction of the explained variability results from the covariance between these components [39]. To avoid this covariation, we used the method based on the Sum of Squares (SS) decomposition from Lepš et al. [40]. The SS can be decomposed into the amount of variability explained by individual terms of the model and the unexplained variability (error). Thus, $\mathrm{SS}_{\text {total }}=\mathrm{SS}_{\text {factor } 1}+\mathrm{SS}_{\text {factor } 2}+\mathrm{SS}_{\text {factor } 1 \times \text { factor } 2}+\mathrm{SS}_{\text {error }}$. If the two effects are positively correlated (i.e. LD and LVA), then the $\mathrm{SS}_{\text {total }}$ will be higher than when the two effects are independent. To obtain the variability explained by each element without covariation, we considered, for example for factor 1, that $\mathrm{SS}_{\text {factor 1 }}=\mathrm{SS}_{\text {total }}-\mathrm{SS}_{\text {error }}-\mathrm{SS}_{\text {factor 2 }}-\mathrm{SS}_{\text {factor }}$ $1 \times$ factor 2 . To obtain the variability explained by each factor we weighted the results for the total variability explained by the model, then, for factor 1 for example, Factor var $1(\%)=100 \times$ $\left[\mathrm{SS}_{\text {factor } 1} / \mathrm{SS}_{\text {total }}\right]$. The Lepš method was developed for a factorial ANOVA, so some differences must be considered for linear regression models (see S1 Appendix).

The relationships of the morphological traits with both the anatomical traits and the $\mathrm{C}$ and $\mathrm{N}$ concentration were also explored by linear regressions. All the relationships were analysed in three ways: considering all species together, or deciduous and evergreen species separately.

In order to allow for the influence of species evolutionary history, Pearson correlation analyses were carried out for all the above-described relationships, by fitting a phylogenetic generalised least squares model. By calculating phylogenetically independent contrasts (PIC), we can assess the impact of phylogeny on our results [41, 42]. For these PICs, we used the pgls function of the caper package [43] for $\mathrm{R}$ ( $\mathrm{R}$ Development Core Team 2011), which addresses phylogenetic non-independence among species by incorporating covariance between taxa into the calculation of the estimated coefficients. The phylogenetic relationships between species (see S2 Fig) were obtained with the help of the Phylomatic program, as implemented in Phylocom 4.2, and the reference phylogeny contained in R20120829.new [41]. We resolved the topology of the tree (below the family level) with information from published phylogenies [42, 44, 45]. The age estimates for nodes in the tree were taken from Verdú et al. [42] and branch lengths were adjusted by using the BLADJ algorithm in Phylocom 4.2. In addition, we conducted a deciduous vs. evergreen comparison for morphological and anatomical traits (in both cases: absolute and percentage values) by fitting a phylogenetic generalised least squares model (PGLS), using the pgls function of the caper package [43] for R.

To summarise all the information, we calculated a correlation network (see Poorter et al. [46]) based on the overall correlations (Pearson's correlation analysis) between the morphological, anatomical and chemical leaf traits. The network analysis was carried out for all the species together and for the deciduous and evergreen species separately.

In order to investigate the relationship between the soil water content and the leaf structural and anatomical traits, we carried out a simple regression analysis ( $\mathrm{R}$ Development Core Team 2011) with all the species, or with the deciduous and evergreen species separately.

\section{Results}

\section{Leaf morphology (LMA, LVA and LD) and anatomy}

Considered over all the species, LMA was positively related with both leaf thickness (LVA; $\mathrm{R}^{2}=$ $0.50)$ and leaf density $\left(\mathrm{LD} ; \mathrm{R}^{2}=0.63\right)($ Fig $1 \mathrm{~A})$. There was no relationship between $\mathrm{LD}$ and LVA $(P>0.05$, data not shown). These patterns were also found for the deciduous and evergreen species considered independently (Fig 1A). Evergreen species showed higher values of LMA and LVA than deciduous species (Fig 1A), but no overall differences were found in LD (Fig 1A, S3 Table). The partitioning of the total variability of LMA among the morphological traits considered (without covariations) demonstrated that $45 \%$ of the LMA variation was due to LD and 33\% to LVA (Fig 1B). Similarly to when considering all the data, LMA variation 
A)

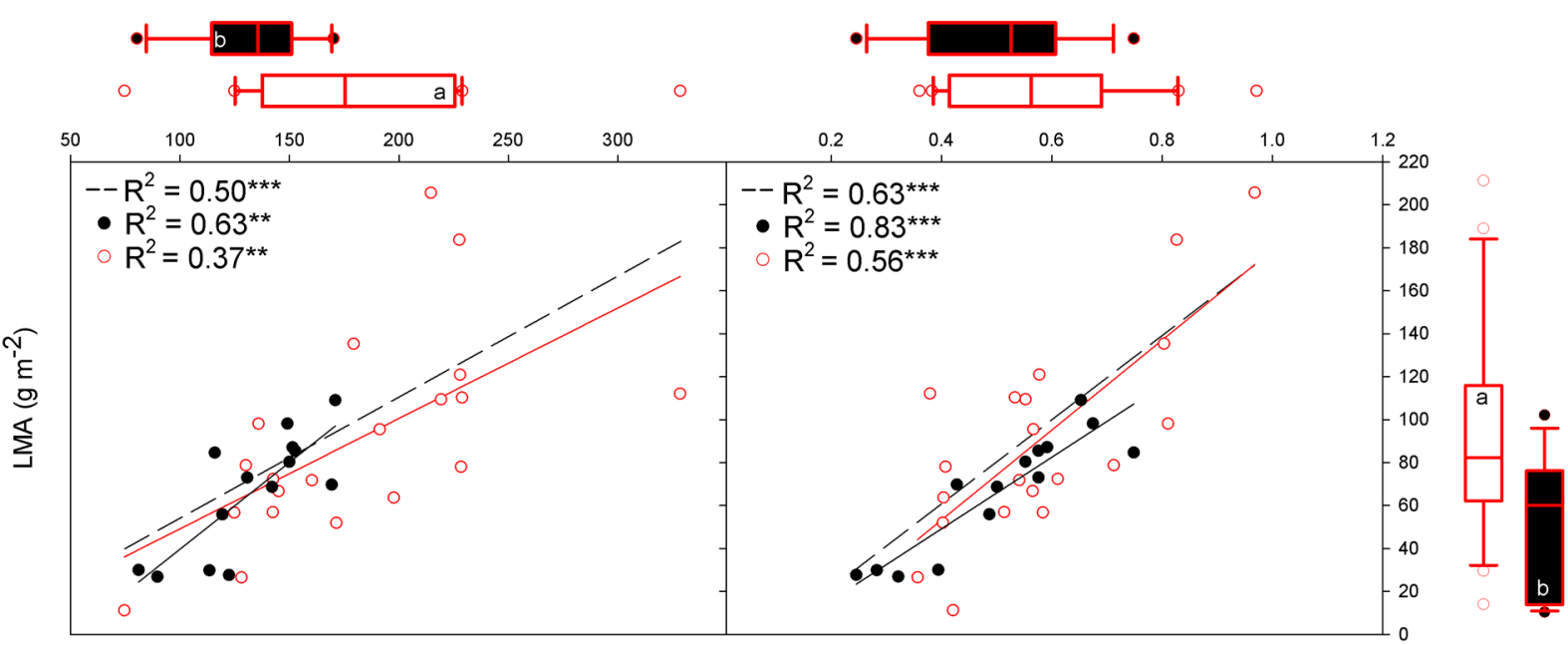

B)

$$
\operatorname{LVA}\left(\mathrm{mL} \mathrm{m}^{-2}\right)
$$

$\operatorname{LD}\left(\mathrm{g} \mathrm{mL}^{-1}\right)$

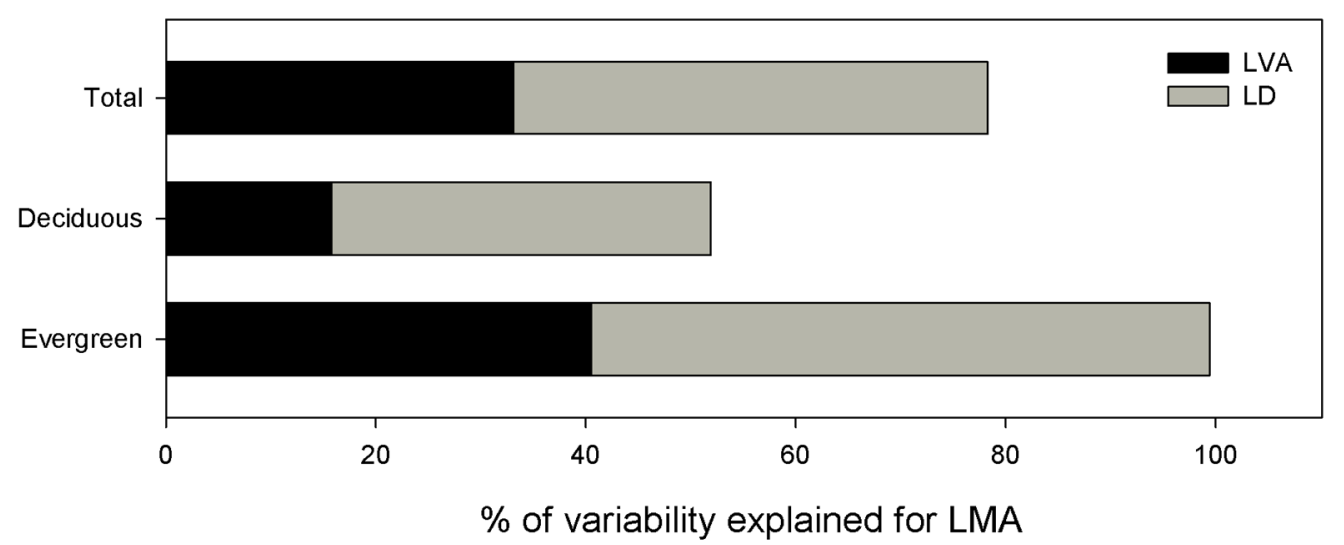

Fig 1. A) Linear regressions of leaf mass per area (LMA) with leaf volume per area (LVA or thickness) and leaf density (LD), for deciduous species (dark line and circles), evergreens (red line and empty red circles) and all the species (dashed line). The level of significance is expressed as follows: * $P<0.05$, ** $P<0.01$, *** $P<0.001$. Box plots (median and $1^{\text {st }}$ and $3^{\text {rd }}$ quartiles) of deciduous vs. evergreen species are included in the margins; the significant results are based on the phylogenetic generalised least squares model (PGLS). The results based on PGLS can be found in S3 Table, Supporting Information. Whiskers show the minimum and maximum values that fall within $1.5 x$ the length of the box away from the interquartile range; data further away are shown as outliers. B) Decomposition of the total variability explained by LVA and LD.

doi:10.1371/journal.pone.0148788.g001

within each functional group was mainly due to variation in LD (Fig 1B). However, the variation in LMA was better explained within evergreens (59\% LD and 40\% LVA) than within deciduous species (36\% LD and 16\% LVA).

The overall variation in LMA, especially in the LVA, was explained partially by the different tissues. Considering all species, the increase in LVA was caused by an increase in the volume per area of all the tissues, but predominantly by the increase in the mesophyll $\left(\mathrm{R}^{2}=0.71\right.$ ) (Fig $2 \mathrm{~A}$ ). Although, in the case of air spaces, the relationship with LVA disappeared when the phylogenetic relationships were taken into account (S4 Table).

The relationship between LVA and the anatomical composition depended on the functional group (deciduous vs. evergreen). For deciduous species, LVA was only related to mesophyll VA (thickness) $\left(\mathrm{R}^{2}=0.90\right)$ and vascular plus sclerenchyma VA $\left(\mathrm{R}^{2}=0.33\right)$ (Fig $\left.2 \mathrm{~A}\right)$, while for evergreen species the increase in LVA was due to an increase in all the tissues, though it was 
A)
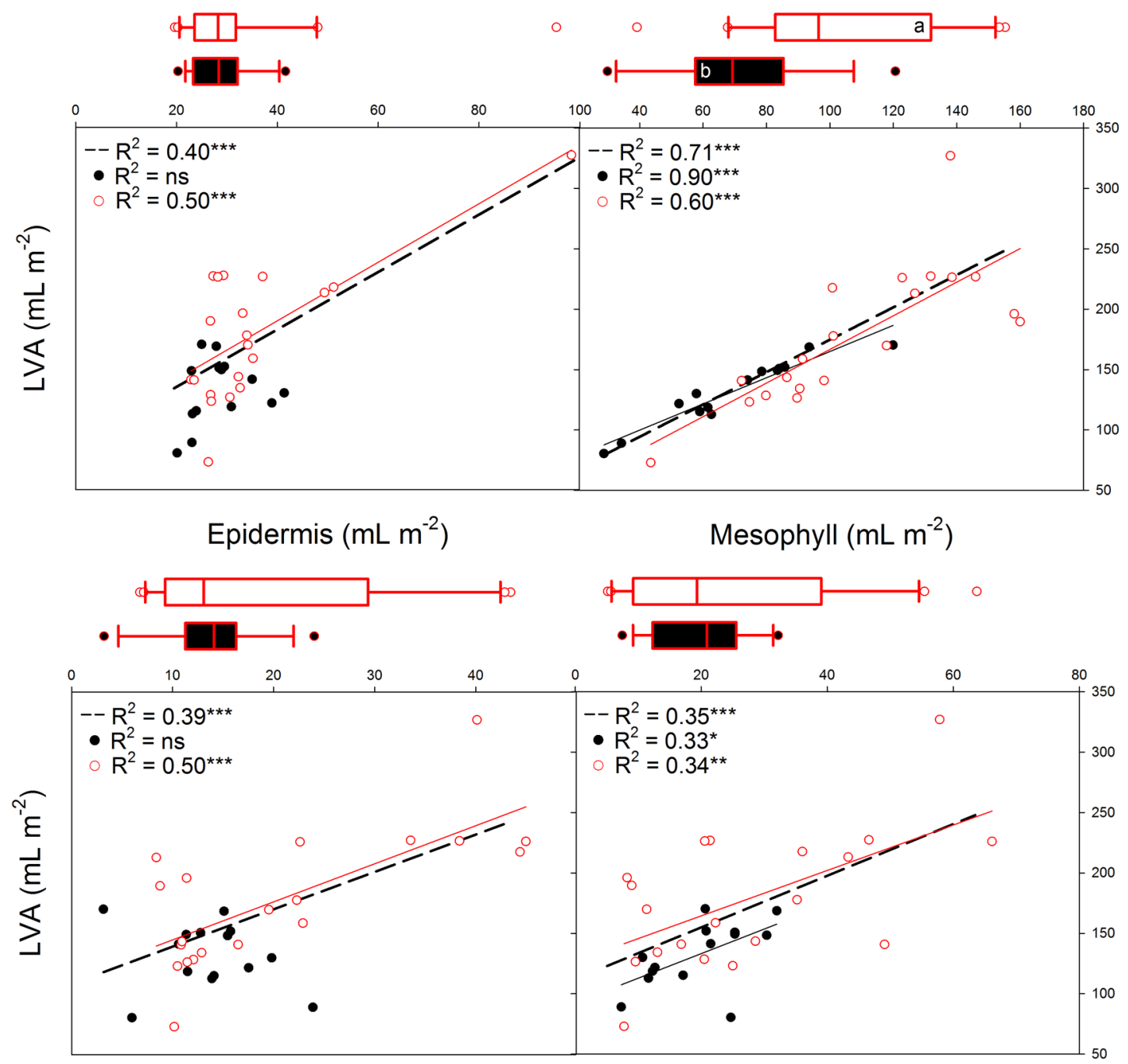

B)

Air Spaces $\left(\mathrm{mL} \mathrm{m}^{-2}\right)$

Vascular plus Sclerenchyma $\left(\mathrm{mL} \mathrm{m}^{-2}\right)$

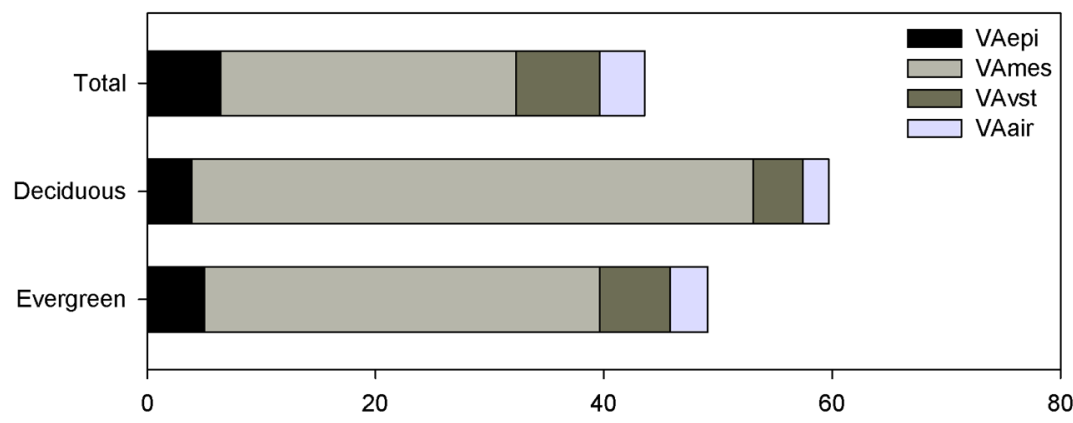

$\%$ of variability explained for LVA

Fig 2. A) Linear regressions of leaf volume per area (LVA or thickness) with anatomical tissues, for deciduous species (dark line and circles), evergreens (red line and empty red circles) and all the species (dashed line). In brackets the slopes of the regression lines are given. The level of significance is expressed as follows: ${ }^{*} P<0.05,{ }^{*} P<0.01,{ }^{* * *} P<0.001$. Box plots (median and $1^{\text {st }}$ and $3^{\text {rd }}$ quartiles) of deciduous vs. evergreen species are included in the margins; the significant results are based on the phylogenetic generalised least squares model (PGLS). The results based on PGLS can be found in S3 Table, Supporting Information. Whiskers show the minimum and maximum values that fall within $1.5 x$ the length of the box away from the interquartile range; data further away are shown as outliers. B) Decomposition of the total variability explained by anatomical tissues, without covariations.

doi:10.1371/journal.pone.0148788.g002 
better explained by mesophyll VA $\left(R^{2}=0.60\right)$ than by the other tissues. The partitioning of the variability showed the importance of the mesophyll VA in the explanation of leaf thickness (Fig 2B) and the secondary role of the other tissues (which together explained less than $20 \%$ of the variance, for both groups of species).

With regard to the relationships of $\mathrm{LD}$ with the proportions of anatomical tissues, we only found some marginally significant results. Thus, $\mathrm{LD}$ was related negatively to the proportion of epidermis and marginally with air spaces $(0.05<P<0.10)$ (S5 Table). Considering each functional group separately, $\mathrm{LD}$ was only marginally and positively related to mesophyll for the deciduous species $(0.05<P<0.10)$ and to vascular plus sclerenchymatic tissue for the evergreens $(0.05<P<0.10)$ (S5 Table).

The evergreens differed from the deciduous species only in mesophyll VA, which was higher in evergreens $(P<0.001$, Fig $2 \mathrm{~A})$. Considering the volumetric fractions, the evergreens showed a higher mesophyll and lower epidermis fraction $(P<0.05)$ than the deciduous species (S2 Table). No systematic differences between the deciduous and evergreen species were found for any of the other tissues.

\section{Relationships of leaf morphology and anatomy with chemical composition}

The relationships of the $\mathrm{C}$ and $\mathrm{N}$ concentrations with the morphological and anatomical traits differed strongly (Fig 3 and Table 1). Leaf $\mathrm{C}$ was positively correlated with LMA, LD and LVA. However, all the correlations (across the 34 species) of leaf $\mathrm{C}$ with the morphological and anatomical traits were influenced by taxonomy; no significant results were found when including PIC in the pairwise correlations (except for LVA and vascular plus sclerenchymatic tissue, $P<0.05$; S4 Table).

The groups of evergreen and deciduous species did not differ in their C concentrations (S2 Table). Within the deciduous species a higher LMA was related to a higher $\mathrm{C}$ concentration (Fig 3). This increase in $\mathrm{C}$ concentration was related to higher values of mesophyll thickness $\left(\mathrm{R}^{2}=0.39, P<0.05\right.$, Fig 3$)$. In the case of the evergreen species, the increase in $C$ concentration was related to an increase in the VA of vascular plus sclerenchymatic tissues $\left(\mathrm{R}^{2}=0.38\right.$, $P<0.01$, Table 1$)$.

Leaf $\mathrm{N}$ concentration showed negative relationships with all morphological traits (LMA, LVA and LD) and mesophyll thickness (Fig 3 and Table 1). Deciduous species showed a higher $\mathrm{N}$ concentration than evergreen species ( $P=0.001$; S2 Table). Within each functional group, only the LD of the deciduous species was negatively related with $\mathrm{N}$ concentration (Table 1).

\section{Network-correlations}

As a summary we present here all the correlations in a network map, for all species and within the evergreen or deciduous species (Fig 4). For all three groups considered (all species, evergreens or deciduous), the variation in LMA was due to variation in both LVA and LD. However, the causes of the variation in LVA differed between the deciduous and evergreen species. For the deciduous species, LVA was mostly explained by mesophyll VA, whereas for the evergreens the variation in LVA was explained by all tissues. There were few significant correlations between leaf composition ( $\mathrm{C}$ and $\mathrm{N}$ ) and LVA or the anatomical traits. Nevertheless, leaf $\mathrm{C}$ seemed to be related to LMA (at least in some groups) and leaf $\mathrm{N}$ to LD, but only for the deciduous species.

\section{Relationships of leaf morphology and anatomy with environmental factors}

Both LMA and LD were negatively correlated with soil water content $(P<0.01$, Fig 5$)$. So, species with high LMA and LD were found in habitats with low water availability. In addition, 


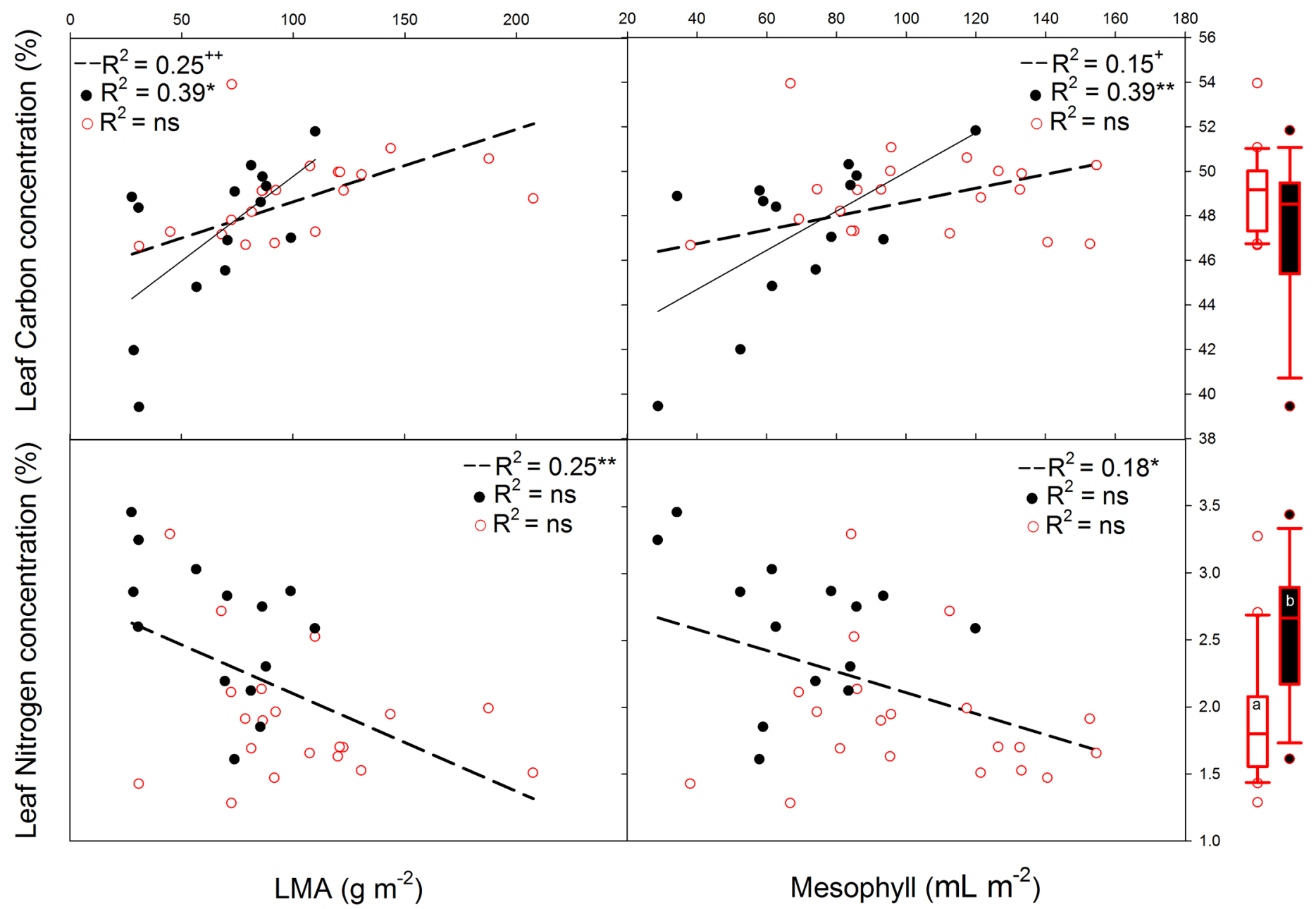

Fig 3. A) Linear regressions of leaf mass area (LMA) and mesophyll with leaf carbon concentration (LCC) and leaf nitrogen concentration (LNC), for deciduous species (dark line and circles), evergreens (red line and empty red circles) and all the species (dashed line). In brackets the slopes of the regression lines are given. The level of significance is expressed as follows: ${ }^{*} P<0.05,{ }^{*} P<0.01,{ }^{* *} P<0.001,{ }^{+}$is shown when the relationship is phylogenetically dependent. Box plots (median and $1^{\text {st }}$ and $3^{\text {rd }}$ quartiles) of deciduous vs. evergreen species are included in the margins; the significant results are based on the phylogenetic generalised least squares model (PGLS). The results based on PGLS can be found in S3 Table, Supporting Information. Whiskers show the minimum and maximum values that fall within $1.5 x$ the length of the box away from the interquartile range; data further away are shown as outliers.

doi:10.1371/journal.pone.0148788.g003

similar results were found for LD and soil water content when deciduous $(P<0.05)$ and evergreen species $(0.05<P<0.10)$ were considered separately. No relationships were found between LVA or the anatomical traits and soil water content (data not shown), in any case.

\section{Discussion}

We found large variability in the values of leaf morphological traits, anatomical tissues and elemental chemical composition among the 34 woody species studied. For instance, according to Poorter et al. [6] the LMA values among terrestrial species in the field generally ranges from 30 to $330 \mathrm{~g} \mathrm{~m}^{-2}$ (based on the 5th and 95th percentiles of the overall distribution of data). In our study, LMA values varied between 27 to $207 \mathrm{~g} \mathrm{~m}^{-2}$, thus covering a large part of the variation in LMA among woody angiosperms. Our results clearly show that this LMA variation was strongly correlated with variation in both the related morphological traits (LVA and LD), 
Table 1. Linear regressions of the morphological and anatomical traits with leaf carbon concentration (LCC) and leaf nitrogen concentration (LNC). The positive or negative relations (Rel) and the $\mathrm{R}^{2}$ of the regressions are shown.

\begin{tabular}{|c|c|c|c|c|c|c|c|c|c|c|c|c|}
\hline & \multicolumn{6}{|c|}{ LCC } & \multicolumn{6}{|c|}{ LNC } \\
\hline & \multicolumn{2}{|c|}{ All } & \multicolumn{2}{|c|}{ Deciduous } & \multicolumn{2}{|c|}{ Evergreen } & \multicolumn{2}{|c|}{ All } & \multicolumn{2}{|c|}{ Deciduous } & \multicolumn{2}{|c|}{ Evergreen } \\
\hline & Rel & $\mathbf{R}^{2}$ & Rel & $\mathbf{R}^{2}$ & Rel & $\mathbf{R}^{2}$ & Rel & $\mathbf{R}^{2}$ & Rel & $\mathbf{R}^{2}$ & Rel & $\mathbf{R}^{2}$ \\
\hline LMA & + & $0.25 * *$ & + & $0.39 *$ & \multicolumn{2}{|c|}{ ns } & - & $0.25 * *$ & \multicolumn{2}{|c|}{ ns } & \multicolumn{2}{|c|}{ ns } \\
\hline LVA & + & $0.14 *$ & + & $0.30 *$ & \multicolumn{2}{|c|}{ ns } & - & $0.22 * *$ & \multicolumn{2}{|c|}{ ns } & \multicolumn{2}{|c|}{ ns } \\
\hline LD & + & $0.19 * *$ & \multicolumn{2}{|c|}{ ns } & \multicolumn{2}{|c|}{ ns } & - & $0.13 *$ & - & $0.30 *$ & & \\
\hline Epidermis VA & \multicolumn{2}{|c|}{ ns } & \multicolumn{2}{|c|}{ ns } & \multicolumn{2}{|c|}{ ns } & \multicolumn{2}{|c|}{ ns } & \multicolumn{2}{|c|}{ ns } & \multicolumn{2}{|c|}{ ns } \\
\hline Mesophyll VA & + & $0.15 *$ & + & $0.39 * *$ & \multicolumn{2}{|c|}{ ns } & - & $0.18 *$ & \multicolumn{2}{|c|}{ ns } & \multicolumn{2}{|c|}{ ns } \\
\hline Vas+Scl VA & + & $0.12 *$ & \multicolumn{2}{|c|}{ ns } & \multirow{2}{*}{\multicolumn{2}{|c|}{$0.38 * *$}} & \multicolumn{2}{|c|}{ ns } & \multicolumn{2}{|c|}{ ns } & \multicolumn{2}{|c|}{ ns } \\
\hline Air spaces VA & \multicolumn{2}{|c|}{ ns } & \multicolumn{2}{|c|}{ ns } & & & \multicolumn{2}{|c|}{ ns } & \multicolumn{2}{|c|}{ ns } & \multicolumn{2}{|c|}{ ns } \\
\hline
\end{tabular}

The level of significance is expressed as follows:

* $P<0.05$,

** $P<0.01$.

doi:10.1371/journal.pone.0148788.t001

through differences in anatomical composition. The species with high LMA and LD were found in habitats with low water availability. We discuss these results in more detail below.

\section{Relationships among LMA, LVA and LD}

The LMA showed stronger dependency on LD (45\%) than on LVA (33\%), but this difference was very small (Fig 1B). Hence, these results support previous field studies with woody species [25] and herbaceous species [47], where variation in LMA was found to depend equally on variation in LVA and LD. However, they contrast with those for seedlings of woody species growing in controlled conditions, for which Castro-Díez et al. [22] and Villar et al. [18] reported strong coordination of LVA and LMA as the result of deciduous vs. evergreen differences. These contradictory results suggest that the relationships of LMA with LVA and LD can present large differences depending on the group of species (evergreens, deciduous) [18], age [48] and environmental conditions [8,27]. In addition, we found no relationship between LVA and $\mathrm{LD}$, indicating that their across-species variation is the result of different mechanisms [25].

Our results show that the deciduous species had lower LVA values than the evergreens, with no differences between leaf habits for LD, similar to the findings of Villar et al. [18]. However, contrary to that study, both groups maintained similar patterns, with positive relationships of LMA with LD and LVA. This similar pattern between different leaf habits suggests that a certain degree of convergence with leaf structure exists. So, the increase of LMA as a result of higher values of LD and LVA seems to be a common pattern for Mediterranean woody species growing in field conditions, independent of leaf habit.

\section{Relationships of anatomical structure with LVA and LD}

In accordance with previous studies $[18,22,24,30,49]$, our results show that, in general, variation in LVA is best explained by variation in the mesophyll VA, especially for deciduous species (Fig 2B). This could be explained by changes in the number of mesophyll cell layers and/or in cell size $[18,34,50]$.

Nevertheless, some modest differences depended on leaf habit: the LVA of deciduous species depended strongly on variation in mesophyll VA (Fig 2), while for evergreen species LVA increased not only with mesophyll VA, but also to some extent with the epidermal VA and 


\section{ALL SPECIES}

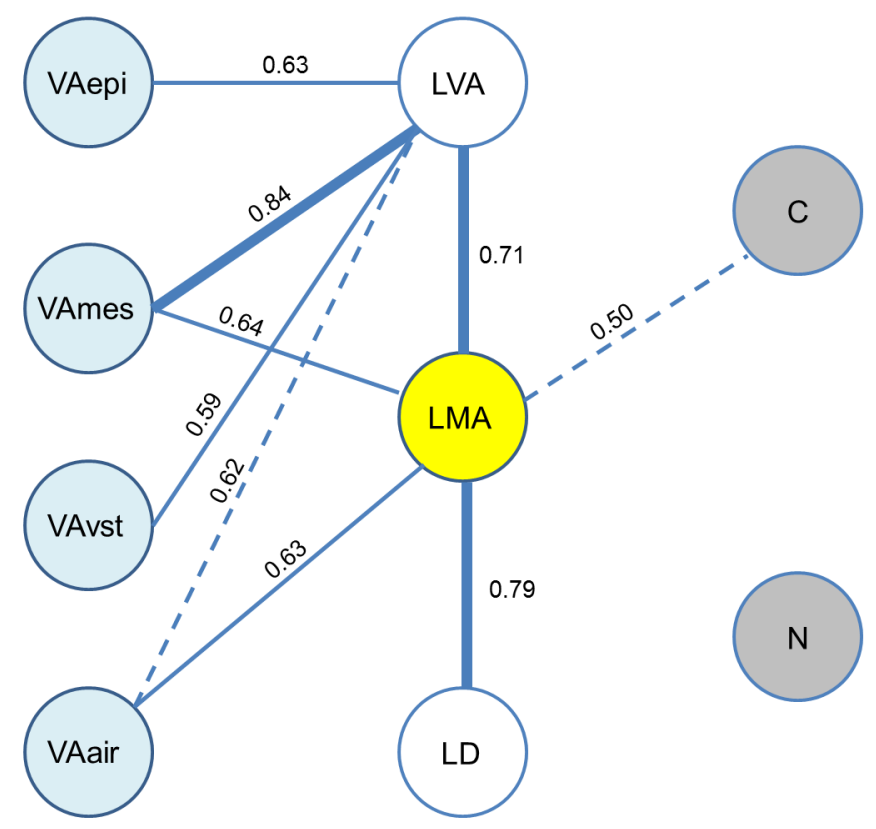

\section{DECIDUOUS}
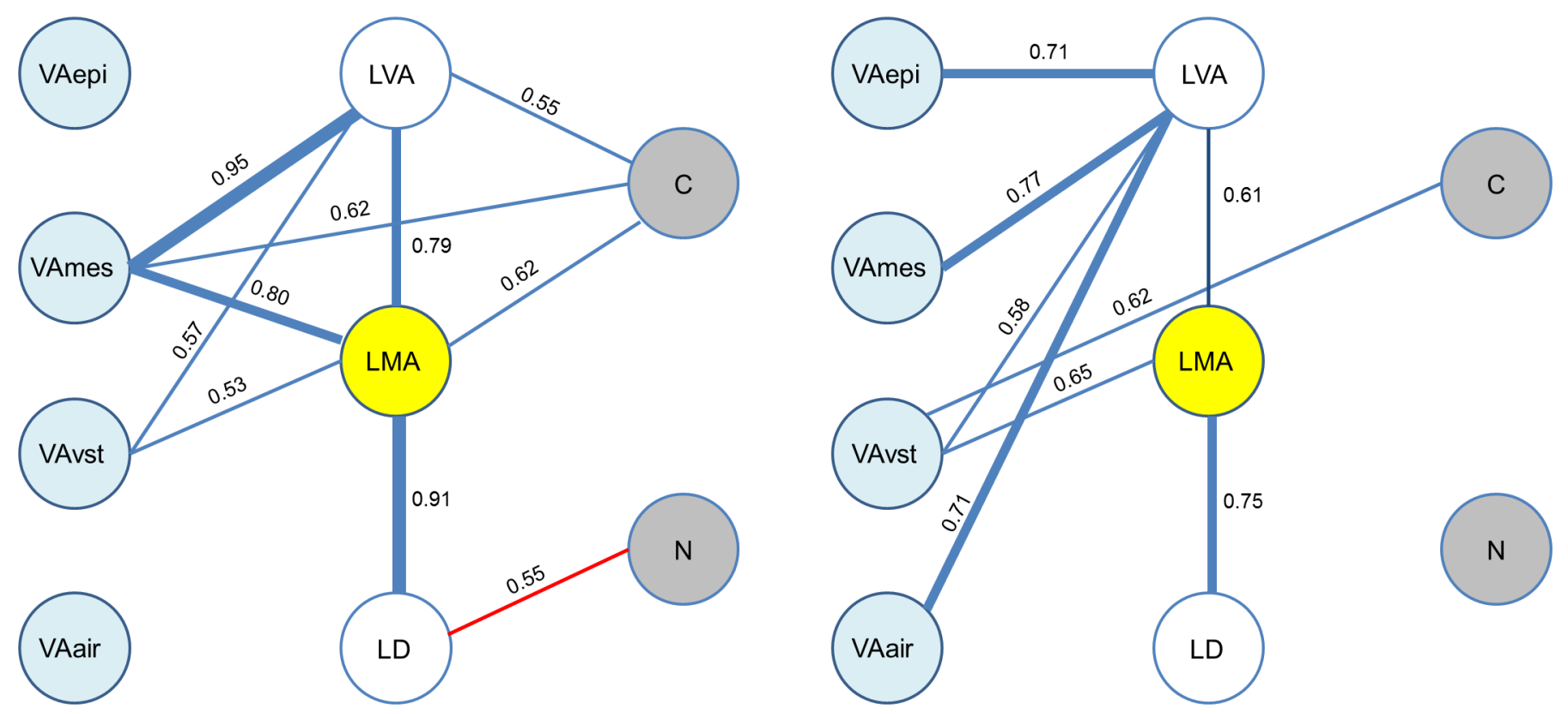

Fig 4. Correlation network for morphological (white), anatomical (blue) and chemical traits (grey), describing the interrelations with LMA (yellow). Blue lines indicate positive correlations and red lines negative correlations. Dashed lines indicate phylogenetic independence. The correlation coefficient is shown. Thin lines, $0.5<|r|<0.707\left(0.25<R^{2}<0.50\right)$; intermediate lines, $0.707<|r|<0.866\left(0.50<R^{2}<0.75\right)$; bold lines, $|r|>0.866\left(R^{2}>0.75\right)$.

doi:10.1371/journal.pone.0148788.g004 

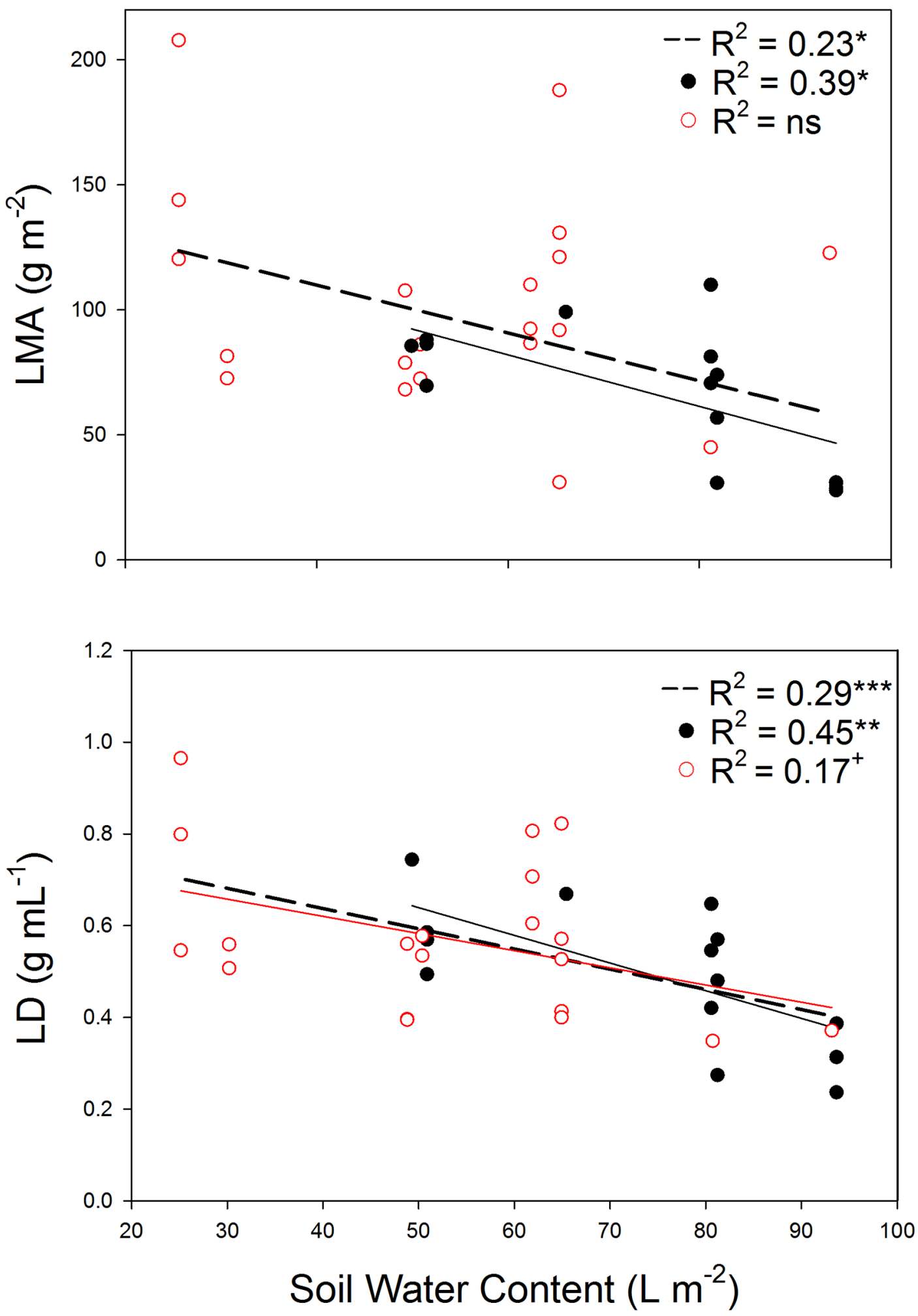

Fig 5. Linear regressions between soil water content and morphological traits (leaf mass per area, LMA and leaf density, LD) for deciduous species (dark line and circles), evergreens (red line and empty red circles) and all the species (dashed line). The level of significance is expressed as follows: ${ }^{+} 0.05<P<0.10,{ }^{* *} P<0.01,{ }^{* * *} P<0.001$

doi:10.1371/journal.pone.0148788.g005 
vascular plus sclerenchymatic tissues and air spaces VA. For deciduous species, the strong relationship between mesophyll VA and LVA could be related to their high rates of photosynthesis per unit leaf mass, which may allow them to be more competitive during the favourable season [51]. In sclerophyllous evergreen leaves, the high LMA and LVA were also due to the structural tissues (vascular and sclerenchymatic tissues VA) [8], which can confer higher leaf resistance to water diffusion from the vein to the mesophyll [22]. Also, evergreen leaves have more air spaces, which can facilitate $\mathrm{CO}_{2}$ diffusion towards the mesophyll [34]. Other studies have also found that variation in LMA depends on variation in vascular and sclerenchymatic tissues [20, 21, 52]. Evergreen leaves often have greater LVA and allocation to mechanical tissue, which could avoid irreparable damage as the result of frost or drought during unfavourable conditions [53].

Similar to Villar et al. [18], we found no difference in leaf density between deciduous and evergreen species. To understand this variation from the results for anatomy, we have considered the fractional volumes of the tissues rather than their volume of tissue per area (VA or thickness) [18]. The volumetric fractions of the mesophyll and vascular tissue were very similar between the two groups. In a previous study [22] with woody species, LD was negatively related with the fraction of epidermis and mesophyll but positively related to the fraction of sclerified tissues. Villar et al. [18] found LD to be negatively related to the fraction of epidermis, as in our dataset, but in our case it explained a low proportion of $L D$ variation $\left(\mathrm{R}^{2}=0.11\right)$. Other variables related to the cell, such as the size and number of cells, could explain differences in LD. For example, the mesophyll cell size, which has been found to be negatively related with the density [22, 28]. Thus, one of the possible reasons for the lack of common patterns of $L D$ at the tissue level is inter-specific variation at the cellular level. However, one limitation of our study is that analysis at the cellular level-that could have shed light on this assumption-was not performed, so more studies are needed to contrast these ideas.

\section{Relationships of leaf morphology and anatomy with chemical composition}

According to our results, variation in LMA, and subsequently in LVA and LD, could have arisen from several factors which pertain to anatomical tissues and also chemical composition $[18,20]$. We found different patterns for the relationships of the $C$ and $N$ concentrations with anatomical tissues. There were positive relationships of LMA, LVA and LD with the C concentration, but these relationships showed a phylogenetic signal (Fig 3 and S4 Table)-indicating that they pertained to certain taxonomic groups. Both the deciduous and evergreen species showed positive relationships between LMA and C, but for different reasons. While a higher LMA of deciduous species was related to an increase in $\mathrm{C}$ concentration in connection with the increase in VA of mesophyll tissues, for evergreen species the increase in LMA was related to the higher $\mathrm{C}$ concentration associated with the increase in VA of vascular plus sclerenchymatic tissues. These results suggest that, whereas deciduous species invest $\mathrm{C}$ in the mesophyll (photosynthetic tissues), an increase of LMA in evergreen species is the result of a greater proportion of $\mathrm{C}$ in structural (non-photosynthetically active) tissue.

By contrast, we found a negative relationship between LMA and N concentration, similar to other studies $[1,20,54,55]$. The $\mathrm{N}$ concentration was also negatively related to LVA, LD and mesophyll VA; however, this pattern was mainly due to the differences between deciduous and evergreen species (Fig 3). These results indicate that deciduous species (short leaf life-spans) with thinner leaves have high photosynthetic rates per unit mass as a result of higher $\mathrm{N}$ concentrations, contrary to evergreen species $[1,54,55]$. In addition, structural differences related to high LD may be the result of a higher proportion of cell wall mass, which in fact implies a 
lower $\mathrm{N}$ concentration $[56,57]$. Hence, this could explain the negative relationship between $\mathrm{N}$ concentration and LD for the deciduous species.

\section{Environmental factors and leaf structure}

Different environmental conditions may impose different selective pressures on plants, driving traits to a certain degree of divergence [6]. Higher values of LMA (or lower values of SLA) contribute to long leaf life-span, nutrient retention and protection from desiccation [58, 59]. In contrast, lower values of LMA (or higher values of SLA) potentially confer an advantage in resource-uptake efficiency, by increasing the absorption surface per unit of tissue biomass [1, 12]. In this regard, our results show that the LMA distribution differed along the soil water gradient, in accordance with general ecological knowledge $[\underline{8}, \underline{34}, \underline{60}, \underline{61}]$ and our previous results -where LMA increased along a gradient of decreasing moisture $[36,59]$. We have assumed that for species occurring in several sites (differing in terms of water availability), the values of a given trait as estimated in only one of the sites are representative for the whole gradient where this species can be found. Although this can modify our results, we think that it can not introduce a major bias in our conclusions, as we consider such a species in one site, connecting its leaf traits with the water content of the soil of this sampling site.

We found that the high LMA in the dry site was partly due to the leaf habit of the species present. Thus, sclerophyllous evergreen species from the driest part of the environmental gradient (such as Quercus ilex or Rosmarinus officinalis) showed higher values of LMA, while deciduous species, at humid sites, showed lower values (i.e. Fraxinus angustifolia or Ulmus minor). On the contrast, deciduous species are usually less tolerant of more-stressing conditions; thus, under strong environmental pressures (such as water scarcity), they are excluded or scarce $[5,59]$. While, in more-productive (e.g. wetter) environments, the disproportional competition limits the supply of light, excluding sclerophyllous evergreen species from these wetter sites [59]. The variation of LD along the soil water gradient was not only the result of leaf habit differences, because this variation was also found within leaf habits. In this regard, the changes in LD distribution along the water gradient could be also related with the changes of leaf elasticity to the water conditions [34]. We want to highlight that the increase in LMA with the decrease of soil water availability was the result of an increase in $\mathrm{LD}$, as no variation was found for LVA or the anatomical traits. This result is not necessarily contradictory: LVA and LD can respond independently to environmental and resource gradients (i.e. moisture or light) and may vary within or between species along the gradient [8]. In this sense, other studies support our results $[8,62]$. Similarly, Poorter et al. [6] also found that LMA increased with water stress and that this change was due more to variation in LD than in LVA.

This decoupling of the tendencies of LD and LVA along the water gradient could have arisen because a high LVA do not necessarily require a long leaf life-span to pay back its cost of construction, while higher LD could be the result of greater foliar pay-back times-because increases in density are related with decreases in net assimilation rate [63]. From the anatomical perspective, experiments within species showed that species growing at low water availability decreased their leaf expansion rates. Thus, under such environmental conditions, the cells are smaller, with thicker walls. Moreover, they are more tightly packed, with a lower fraction of air spaces [19,64-66]. These alterations of leaf tissues increase leaf density [34] and could be the mechanism that promotes these variations between species.

\section{Conclusions}

Our results confirm that for woody Mediterranean plants, LMA variation was strongly coordinated by both LD and LVA, through differences in anatomical composition. For woody plants 
growing along a natural water gradient, we observed that the increase in LVA was mainly due to a greater VA of mesophyll, but, in evergreen species, LVA also depended slightly on the VA of other anatomical tissues. However, leaf density variation was not strongly related to variation in anatomical tissues. In addition, we also confirmed that morphological, anatomical and chemical characteristics differed between leaf habits: thus, deciduous species showed lower values of LMA, LVA and mesophyll thickness and higher leaf $\mathrm{N}$ concentration than evergreens. Along the water gradient studied, the environmental factors seem to exert a significant effect on the selection of species with certain leaf traits, resulting in the dominance of species with higher values of LMA and LD in the driest part of the gradient.

\section{Supporting Information}

S1 Appendix. Description of the calculation of the variance explained by the different sources (LVA and LD or anatomical tissues).

(DOC)

S1 Fig. Cross-section of the 34 species studied.

S2 Fig. The phylogenetic tree of the 34 species studied.

(DOC)

S1 Table. Species studied and areas where the samples were collected.

(DOC)

S2 Table. Location of the sampling sites.

(DOC)

S3 Table. Mean \pm SD values of the leaf traits for deciduous and evergreen species. (DOC)

S4 Table. Pearson correlation coefficients between leaf traits. (DOC)

S5 Table. Linear regressions between leaf density (LD) and anatomical tissues. (DOC)

S6 Table. Mean data of leaf traits and soil water content (SWC). (DOC)

\section{Acknowledgments}

We thank Miguel Verdú for his help in the construction of the phylogenetic tree and in the analyses. Maria del Pilar de Gracia helped with the anatomical analyses. We thank Cristina Armas and two anonymous reviewers for their constructive comments. Analysis of leaf $\mathrm{N}$ and C was carried out in the SCAI of the University of Córdoba.

\section{Author Contributions}

Conceived and designed the experiments: RV EGDR. Performed the experiments: EGDR MO. Analyzed the data: EGDR RV MO JLU HP. Contributed reagents/materials/analysis tools: EGDR MO JLU. Wrote the paper: EGDR RV HP. 


\section{References}

1. Wright IJ, Reich PB, Westoby M, Ackerly DD, Baruch Z, Bongers F, et al. The worldwide leaf economics spectrum. Nature 2004; 428: 821-827. PMID: 15103368

2. Garnier E, Navas ML. A trait-based approach to comparative functional plant ecology: concepts, methods and applications for agroecology. A review. Agronomy for Sustainable Development 2012; 32: 365-399.

3. Sack L, Scoffoni C, John G P, Poorter H, Mason CM, Mendez-Alonzo R, et al. How do leaf veins influence the worldwide leaf economic spectrum? Review and synthesis. Journal of Experimental Botany 2013; 64: 4053-4080. doi: 10.1093/jxb/ert316 PMID: 24123455

4. Reich PB. The worldwide 'fast-slow' plant economics spectrum: a traits manifesto. Journal of Ecology 2014; 102: 275-301.

5. Lopez-Iglesias B, Villar R, Poorter L. Functional traits predict drought performance and distribution of Mediterranean woody species. Acta Oecologica 2014; 56: 10-18. doi: 10.1016/j.actao.2014.01.003

6. Poorter H, Niinemets Ü, Poorter L, Wright IJ, Villar R. Causes and consequences of variation in leaf mass per area (LMA): a meta-analysis. New Phytologist 2009; 182: 565-588. PMID: 19434804

7. Lopez-Iglesias B, Olmo M, Gallardo A, Villar R. Short-term effects of litter from 21 woody species on plant growth and root development. Plant and Soil 2014; 381: 177-191. doi: 10.1007/s11104-0142109-6

8. Witkowski ETF, Lamont BB. Leaf specific mass confounds leaf density and thickness. Oecologia 1991; 88: 486-493.

9. Oren R, Schulze ED, Matyssek R, Zimmermann R. Estimating photosynthetic rate and annual carbon gain in conifers from specific leaf weight and leaf biomass. Oecologia 1986; 70: 178-193.

10. Reich PB, Walters MB, Ellsworth DS. From tropics to tundra: global convergence in plant functioning. Proceedings of the National Academy of Sciences of the USA 1997; 94: 13730-13734. PMID: 9391094

11. Quero JL, Villar R, Marañon T, Zamora R. Interactions of drought and shade effects on seedlings of four Quercus species: physiological and structural leaf responses. New Phytologist 2006; 170: 819834. PMID: 16684241

12. Reich PB, Walters MB, Ellsworth DS. Leaf life-span in relation to leaf, plant, and stand characteristics among diverse ecosystems. Ecological Monographs 1992; 62: 365-392.

13. Poorter $\mathrm{H}$, Van der Werf $\mathrm{A}$. Is inherent variation in RGR determined by LAR at low irradiance and by NAR at high irradiance? A review of herbaceous species. In: Lambers H., Poorter H. \& Van Vuuren M. M.I. (eds.) Inherent variation in plant growth. Backhuys Publishers, Leiden, NL. 1998; pp. 309-336.

14. Antúnez I, Retamosa EC, Villar R. Relative growth rate in phylogenetically related deciduous and evergreen woody species. Oecologia 2001; 128: 172-180.

15. Ruíz-Robleto J, Villar R. Relative growth rate and biomass allocation in ten woody species with different leaf longevity using phylogenetic independent contrasts (PICs). Plant Biology 2005; 7: 484-494. PMID: 16163613

16. Cornelissen JHC, Thompson K. Functional leaf attributes predict litter decomposition rate in herbaceous plants. New Phytologist 1997; 135: 109-114.

17. Cornelissen JHC, Pérez-Hargundeguy N, Díaz S, Grime JP, Marzano B, Cabido M, et al. Leaf structure and defence control litter decomposition rate across species and life forms in regional floras on two continents. New Phytologist 1999; 143: 191-200.

18. Villar R, Ruiz-Robleto J, Ubera JL, Poorter H. Exploring variation in leaf mass per area (LMA) from leaf to cell: An anatomical analysis of 26 woody species. American Journal of Botany 2013; 100: 19691980. doi: 10.3732/ajb.1200562 PMID: 24107583

19. Shield LM. Leaf xeromorphy as related to physiological and structural influences. Botanical Review 1950; 16: 399-447.

20. Garnier E, Laurent G. Leaf anatomy, specific mass and water content in congeneric annual and perennial grass species. New Phytologist 1994; 128: 725-736.

21. Van Arendonk JJCM, Poorter $\mathrm{H}$. The chemical composition and anatomical structure of leaves of grass species differing in relative growth rate. Plant, Cell \& Environment 1994; 17: 963-970.

22. Castro-Díez P, Puyravaud JP, Cornelissen JHC. Leaf structure and anatomy as related to leaf mass per area variation in seedlings of a wide range of woody plant species and types. Oecologia 2000; 124 476-486.

23. de la Riva EG, Pérez-Ramos IM, Navarro-Fernández CM, Olmo M, Marañón T, Villar R. Estudio de rasgos funcionales en el género Quercus: estrategias adquisitivas frente a conservativas en el uso de recursos. Ecosistemas 2014; 23(2): 82-89, 
24. Choong MF, Lucas PW, Ong JSY, Pereira B, Tan HTW, Turner IM. Leaf fracture toughness and sclerophylly: their correlations and ecological implications. New Phytologist 1992; 121: 597-610.

25. Niinemets U. Components of leaf dry mass per area - thickness and density-alter leaf photosynthetic capacity in reverse directions in woody plants. NewPhytologist 1999; 144: 35-47.

26. Shipley B. Structured interspecific determinants of specific leaf area in 34 species of herbaceous angiosperms. Functional Ecology 1995; 9: 312-319.

27. Meziane D, Shipley B. Interacting determinants of specific leaf area in 22 herbaceous species: Effects of irradiance and nutrient availability. Plant, Cell \& Environment 1999; 22: 447-459.

28. Pyankow VI, Kondratchuk AV, Shipley B. Leaf structure and specific leaf mass: The alpine desert plants of the Eastern Pamirs, Tadjikistan. New Phytologist 1999; 143: 131-142.

29. Roderick ML, Berry SL, Saunders AR, Noble IR. On the relationship between the composition, morphology and function of leaves. Functional Ecology 1999; 13: 696-710.

30. Mediavilla S, Escudero A, Heilmeier H. Internal leaf anatomy and photosynthetic resource-use efficiency: interspecific and intraspecific comparisons. Tree physiology 2001; 21: 251-259. PMID: 11276419

31. Dominguez MT, Aponte C, Pérez-Ramos IM, García LV, Villar R, Marañón T. Relationships between leaf morphological traits, nutrient concentrations and isotopic signatures for Mediterranean woody plant species and communities. Plant and Soil 2012; 357: 407-424. doi: 10.1007/s11104-012-1214-7

32. Field C, Mooney HA. The photosynthesis-nitrogen relationship in wild plants. In: On the Economy of Form and Function (ed. Givnish T.J.), Cambridge University Press, Cambridge, UK. 1986, pp. 25-55.

33. Turner IM. A quantitative analysis of leaf form in woody plants from the world's major broadleaved forest types. Journal of Biogeography 1994; 21: 413-419.

34. Niinemets U. Global-scale climatic controls of leaf dry mass per area, density, and thickness in trees and shrubs. Ecology 2001; 82: 453-469.

35. Villar R, Merino JA. Comparison of leaf construction cost in woody species with differing leaf life-spans in contrasting ecosystems. New Phytologist 2001; 151:213-226.

36. de la Riva EG, Pérez-Ramos IM, Tosto A, Navarro-Fernández CM, Olmo M, Marañón T, et al. Disentangling the relative importance of species occurrence, abundance and intraspecific variability in community assembly: a trait-based approach at the whole-plant level in Mediterranean forests. Oikos 2015; doi: 10.1111/oik.01875

37. Garnier E, Shipley B, Roumet C, Laurent G. A standardized protocol for the determination of specific leaf area and leaf dry matter content. Functional Ecology 2001; 15: 688-695.

38. Pérez-Harguindeguy N, Díaz S, Garnier E, Lavorel S, Poorter H, Jaureguiberry P et al. New handbook for standardised measurement of plant functional traits worldwide. Australian Journal of Botany 2013; 61(3): 167-234.

39. Renton $\mathrm{M}$, Poorter $\mathrm{H}$. Using log-log scaling slope analysis for determining the contributions to variability in biological variables such as leaf mass per area (LMA): Why it works, when it works and how it can be extended. New Phytologist 2011; 190: 5-8. doi: 10.1111/j.1469-8137.2010.03629.x PMID: 21275994

40. Lepš J, de Bello F, Šmilauer P, Doležal J. Community trait response to environment: disentangling species turnover vs intraspecific trait variability effects. Ecography 2011; 34: 856-863.

41. Webb CO, Ackerly DD, Kembel SW. Phylocom: software for the analysis of phylogenetic community structure and trait evolution. Bioinformatics 2008; 24: 2098-2100. doi: 10.1093/bioinformatics/btn358 PMID: 18678590

42. Verdú M, Pausas JG. Syndrome driven diversification in a Mediterranean ecosystem. Evolution 2013; 67: 1756-1766. doi: 10.1111/evo.12049 PMID: 23730767

43. Orme D. R-Forge: comparative analyses of phylogenetics and evolution in R. 2011; see http://cran. rproject.org/web/packages/caper/index.html.

44. Manos PS, Doyle JJ, Nixon KC. Phylogeny, biogeography, and processes of molecular differentiation in Quercus subgenus Quercus (Fagaceae). Molecular Phylogenetics and Evolution 1999; 12: 333-49. PMID: 10413627

45. Fernández-Mazuecos $\mathrm{M}$, Vargas $\mathrm{P}$. Ecological rather than geographical isolation dominates Quaternary formation of Mediterranean Cistus species. Molecular Ecology 2010; 19: 1381-1395. doi: 10. 1111/j.1365-294X.2010.04549.x PMID: 20196815

46. Poorter H, Lambers H, Evans JR. Trait correlation networks: a whole-plant perspective on the recently criticized leaf economic spectrum. New Phytologist 2014; 201: 378-382. doi: 10.1111/nph.12547 PMID: 24117716

47. Wilson PJ, Thompson K, Hodgson JG. Specific leaf area and leaf dry matter content as alternative predictors of plant strategies. New Phytologist 1999; 143:155-162. 
48. Mediavilla S, Escudero A. Photosynthetic capacity integrated over the lifetime of a leaf is predicted to be independent of leaf longevity in some tree species. New Phytologist 2003; 159: 203-211.

49. Slaton MR, Smith WK. Mesophyll architecture and cell exposure to intercellular air space in alpine, desert, and forest species. International Journal of Plant Sciences 2002; 163: 937-948.

50. John GP, Scoffoni C, Sack L. Allometry of cells and tissues within leaves. American Journal of Botany 2013; 100: 1936-1948. doi: 10.3732/ajb.1200608 PMID: 24070860

51. Givnish TJ. Ecological constraints on the evolution of plasticity in plants. Evolutionary Ecology 2002; 16: 213-242.

52. Pammenter NW, Drennan PM, Smith VR. Physiological and anatomical aspects of photosynthesis of two Agrostis species at a sub-antarctic island. New Phytologist 1986; 102: 143-160.

53. Chabot BF, Hicks DJ. The ecology of leaf life spans. Annual Review of Ecology and Systematics 1982; 13: 229-259.

54. Reich PB, Uhl C, Walters MB, Ellsworth DS. Leaf lifespan as a determinant of leaf structure and function among 23 Amazonian tree species. Oecologia 1991; 86: 16-24.

55. Villar R, Ruíz-Robleto J, De Jong Y, Poorter H. Differences in construction costs and chemical composition between deciduous and evergreen woody species are small as compared to differences between families. Plant, Cell \& Environment 2006; 29: 1629-1643.

56. Niemann GJ, Pureveen JBM, Eijkel GB, Poorter H, Boon JJ. Differences in relative growth rate in 11 grasses correlate with differences in chemical composition as determined by pyrolysis mass spectrometry. Oecologia 1992; 89: 567-573.

57. Poorter $\mathrm{H}$, Villar $\mathrm{R}$. The fate of acquired carbon in plants: chemical composition and construction costs. In: Bazzaz FA, Grace J (eds), Resource Allocation in Plants. Academic Press. 1997; pp 39-72.

58. Mooney HA, Dunn EL. Convergent evolution of Mediterranean-climate evergreen sclerophyllous shrubs. Evolution 1970; 24: 292-303.

59. de la Riva EG, Tosto A, Perez-Ramos IM, Navarro-Fernandez CM, Olmo M, Anten NPR, et al. A plant economics spectrum in Mediterranean forests along environmental gradients: is there coordination among leaf, stem and root traits? Journal of Vegetation Science 2016; 27: 187-199; doi: 10.1111/jvs. 12341

60. Cunningham SA, Summerhayes B, Westoby M. Evolutionary divergences in leaf structure and chemistry, comparing rainfall and soil nutrient gradients. Ecological Monographs 1999; 69: 569-588.

61. Wright IJ, Reich PB, Westoby M. Strategy-shifts in leaf physiology, structure and nutrient content between species of high and low rainfall, and high and low nutrient habitats. Functional Ecology 2001; 15: 423-434.

62. Groom P, Lamont BB. Xerophytic implications of increased sclerophylly: interactions with water and light in Hakea psilorrhyncha seedlings. New Phytologist 1997; 136: 231-237.

63. Niinemets $U$, Kull $O$, Tenhunen JD. Variability in leaf morphology and chemical composition as a function of canopy light environment in co-existing trees. International Journal of Plant Sciences 1999; 160: 837-848. PMID: 10506464

64. Maximov NA. The plant in relation to water. A study of the physiological basis of drought resistance. 1929. London, UK: Allen \& Unwin.

65. Cutler JM, Rains DW, Loomis RS. The importance of cell size in the water relations of plants. Physiologia Plantarum 1977; 40: 255-260.

66. Utrillas MJ, Alegre L. Impact of water stress on leaf anatomy and ultrastructure in Cynodon dactylon (L.) Pers under natural conditions. International Journal of Plant Sciences 1997; 158: 313-324. 


\section{S1 Appendix. Description of the calculation of the variance explained by the different sources (LVA and LD or anatomical tissues)}

According to Lepš et al. (2011), the Sum of Squares (SS) can be decomposed into the amount of variability explained by individual terms of the model (in this example, two factors: mowing and fertilisation) and the unexplained variability (error). Thus:

$$
\mathrm{SS}_{\text {total }}=\mathrm{SS}_{\text {factor } 1}+\mathrm{SS}_{\text {factor } 2}+\mathrm{SS}_{\text {factor } 1 \times \text { factor } 2}+\mathrm{SS}_{\text {error }}
$$

Table 1. Table obtained from Lepš et al. (2011), where results from two-way ANOVAs analysis and sum of squares (SS) decomposition are shown.

\begin{tabular}{lrrrcc}
\hline & \multicolumn{5}{c}{ Fixed } \\
\cline { 2 - 6 } & \multicolumn{1}{c}{ SS } & DF & MS & F & p \\
\hline Mowing & 57.26 & 1 & 57.26 & 3.672 & $0.092^{*}$ \\
Fertilization & 49.29 & 1 & 49.29 & 3.161 & 0.113 \\
Mowing $\times$ Fertil & 0.16 & 1 & 0.16 & 0.01 & 0.922 \\
Error & 124.73 & 8 & 15.59 & & \\
\hline
\end{tabular}

Thus, the effect of one factor without covariation is:

$$
\mathrm{SS}_{\text {factor } 1}=\mathrm{SS}_{\text {total }}-\left(\mathrm{SS}_{\text {error }}+\mathrm{SS}_{\text {factor } 2}+\mathrm{SS}_{\text {factor } 1 \times \text { factor } 2}\right)
$$

This example is calculated for an ANOVA factorial analysis (with qualitative factors), where decomposition of the different components can be obtained in the same analysis (see Table 1). However, in the case of the multiple regressions no decomposition of the $\mathrm{SS}$ exists. If we consider a multiple regression with two independent variables (factor 1 and factor 2), the results of the SS is:

$$
\mathrm{SS}_{\text {total }}=\mathrm{SS}_{\text {[factor 1, factor 2] }}+\mathrm{SS}_{\text {error }}
$$

In the case of LMA (see Table 2) a multiple regression was performed with two independent variables (LVA and LD). Thus, the total of the model is explained as:

Table 2. Results from the multiple regression between LMA and both LVA and LD.

\begin{tabular}{lccccc}
\hline & SS & DF & MS & F & Sig. \\
\cline { 2 - 6 } LVA, LD & 53455 & 2 & 26727 & 363.4 & $<0.001$ \\
Error & 2280 & 31 & 73.6 & & \\
Total & 55735 & 33 & & & \\
\hline
\end{tabular}

Dependent variable: LMA

Independent variables: LVA, LD 
In order to obtain the variability explained by each independent component (LVA and LD) we could make a simple regression analysis with each component separately. However, if the two effects are positively correlated (i.e. LD and LVA), then the SS explained will be higher than when the two effects are independent. Thus, the sum of the SS explained by each component independently is higher than the $\mathrm{SS}_{\text {total }}$.

For example, as observed in Table 3, when some correlation exists between elements the total SS explained by the model using each factor separately $\left(\mathrm{SS}_{\mathrm{LD}}+\mathrm{SS}_{\mathrm{LVA}}=35014\right.$ $+28264=63278$ ) is higher than the total SS explained by the two variables included in the multiple regression model $\left(\mathrm{SS}_{[\mathrm{LD}, \mathrm{LVA}]}=53455\right)$, or even than the $\mathrm{SS}_{\text {total }}$ explained by the multiple regression model (55735).

$-\mathrm{SS}_{\mathrm{LD}}$ refers to the SS explained with a linear regression of LMA with LD.

$-\mathrm{SS}_{\mathrm{LVA}}$ refers to the SS explained with a linear regression of LMA with LVA.

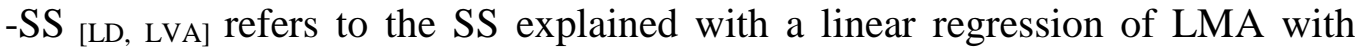
LVA.

Table 3. Sum of squares decomposition from the different regression analyses with LMA: A) multiple regression between LMA and both LD and LVA, B) simple regression between LMA and LVA and $\mathbf{C}$ ) simple regression between LMA and LD.

\begin{tabular}{lccc} 
& A & B & C \\
\hline \multirow{3}{*}{ SS_explained } & {$[$ LVA, LD $]$} & LVA & LD \\
\cline { 2 - 4 } SS_error & 53455 & 35014 & 28264 \\
SS_total & 2280 & 20722 & 27471 \\
\hline & 55735 & 55735 & 55735 \\
\hline
\end{tabular}

In order to avoid the covariation effect and discern the explanatory percentage of each independent factor (without covariation), we should analyse each factor independently and then we can obtain the difference between the total model $\left(\mathrm{SS}_{[\mathrm{LD}}, \mathrm{LVA}\right]$ and the model explained with the other component, thus in general:

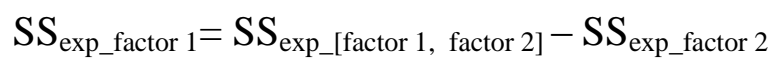

According to this, in our example with LMA:

$$
\mathrm{SS}_{\mathrm{LD}}=\mathrm{SS}_{[\mathrm{LD}, \mathrm{LVA}]}-\mathrm{SS}_{\mathrm{LVA}} ; \quad \text { and } \quad \mathrm{SS}_{\mathrm{LVA}}=\mathrm{SS}_{[\mathrm{LD}, \mathrm{LVA}]}-\mathrm{SS}_{\mathrm{LD}}
$$

Then, we can calculate the percentage of variation of LMA due to LD or LVA as:

$$
\operatorname{LD}(\%)=100 \times\left[\mathrm{SS}_{\mathrm{LD}} / \mathrm{SS}_{\text {total }}\right] ; \quad \operatorname{LVA}(\%)=100 \times\left[\mathrm{SS}_{\mathrm{LVA}} / \mathrm{SS}_{\text {total }}\right]
$$


Table 4. The variability of LMA explained by each independent factor (LD and LVA).

\begin{tabular}{|c|c|c|c|c|}
\hline & & & LVA & LD \\
\hline & Total & [LVA, LD] & $S S_{[L V A, L D]}-S S_{L D}$ & $S S_{[L V A, L D]}-S S_{L V A}$ \\
\hline SS & 55735 & 53455 & 18441 & 25191 \\
\hline$\%$ & & 96 & 33 & 45 \\
\hline
\end{tabular}

So, in this case, we can conclude that the variation in LMA is explained by LD (45 \%) and LVA (33\%).

We used the same criterion to obtain the variability explained by the different components from the LVA. First, we performed the multiple regression analysis with all the histological components $\left(\mathrm{SS}_{\mathrm{LVA}}=\mathrm{SS}_{\text {[VAepi, VAmes, VAvst, VAair] }}\right)$, obtaining the total variability explained by the model. After that, we carried out multiple regressions, removing one component in each multiple regression. For example, the variability explained by the epidermis is:

$$
\left.\mathrm{SS}_{\mathrm{VAepi}}=\mathrm{SS}_{\mathrm{LVA}}-\mathrm{SS}_{[\mathrm{VAmes}, \text { VAvst, }} \text { VAair }\right]
$$

We proceed with the same calculations for all the tissues.

\section{References}

Lepš J, de Bello F, Šmilauer P, Doležal J. Community trait response to environment: disentangling species turnover vs intraspecific trait variability effects. Ecography 2011; 34: 856- 863. 
S1 Fig. Cross sections of the 34 species studied.

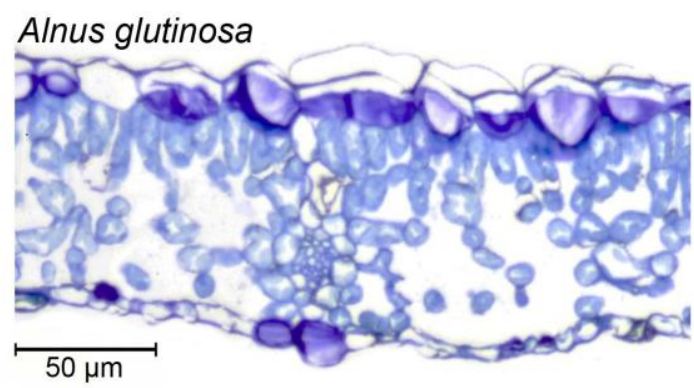

Arbutus unedo
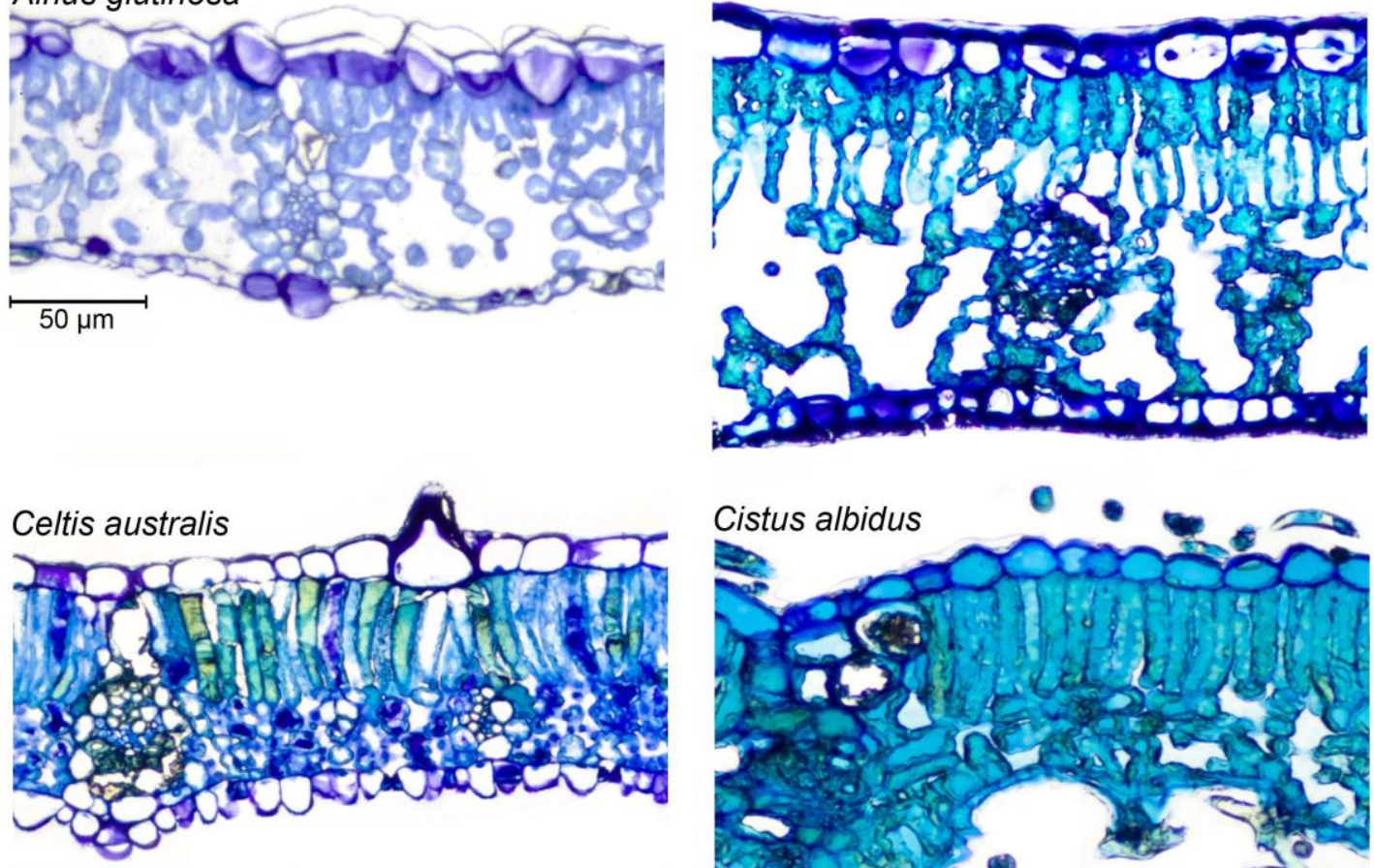

$50 \mu \mathrm{m}$

Cistus crispus
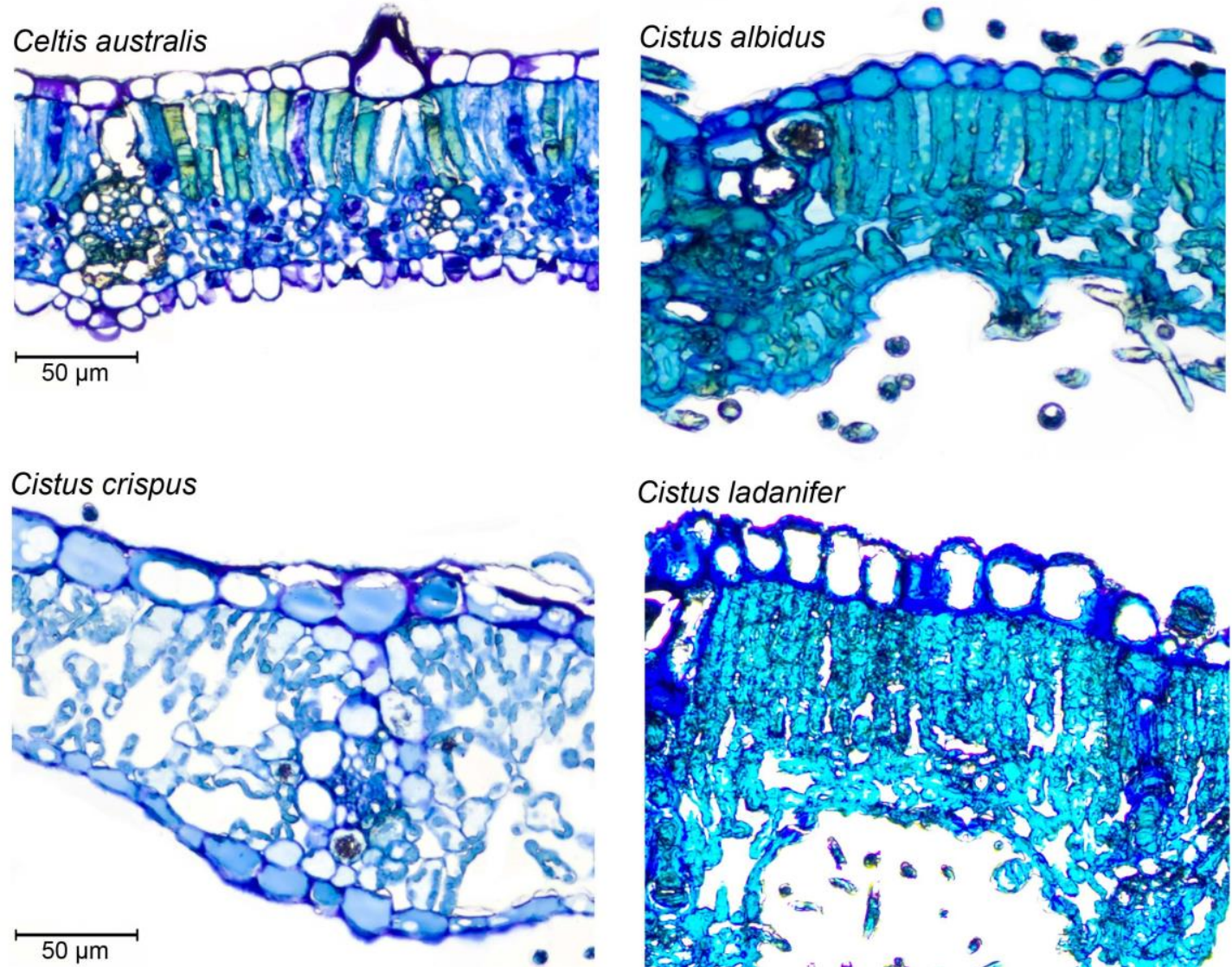

Cistus ladanifer

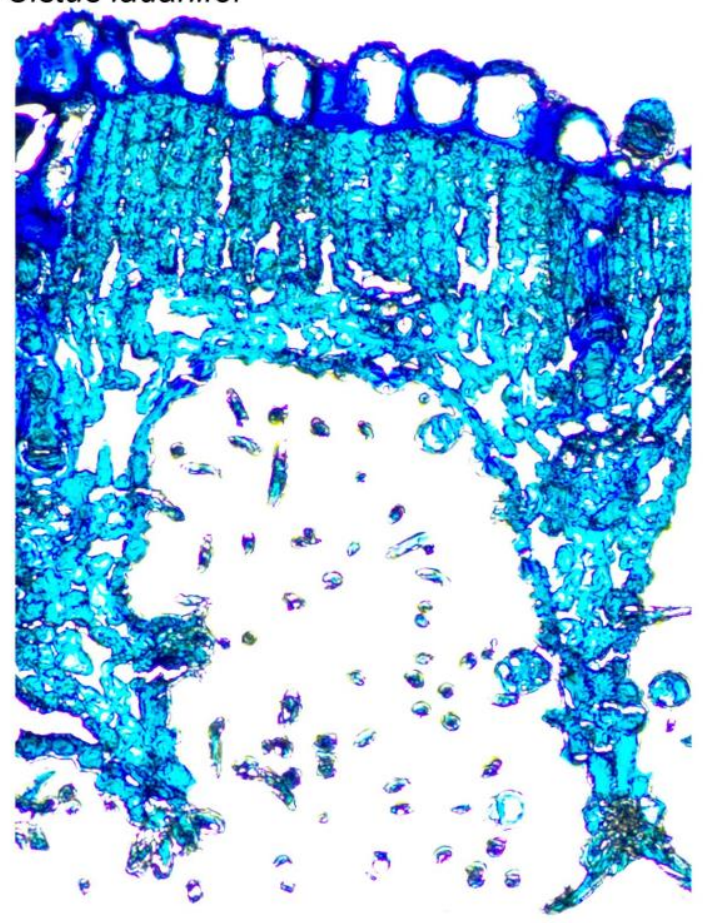


Cistus monspeliensis

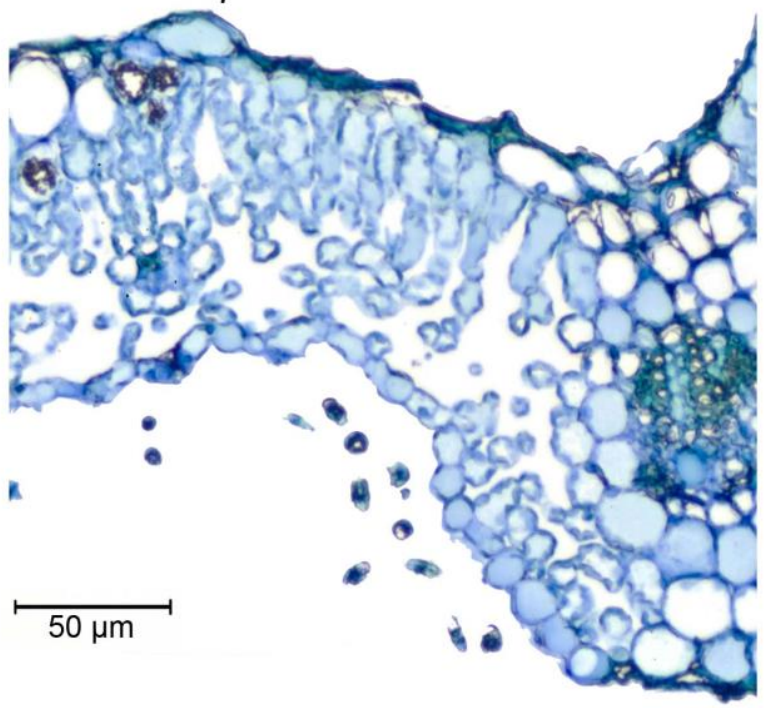

Cydonia oblonga

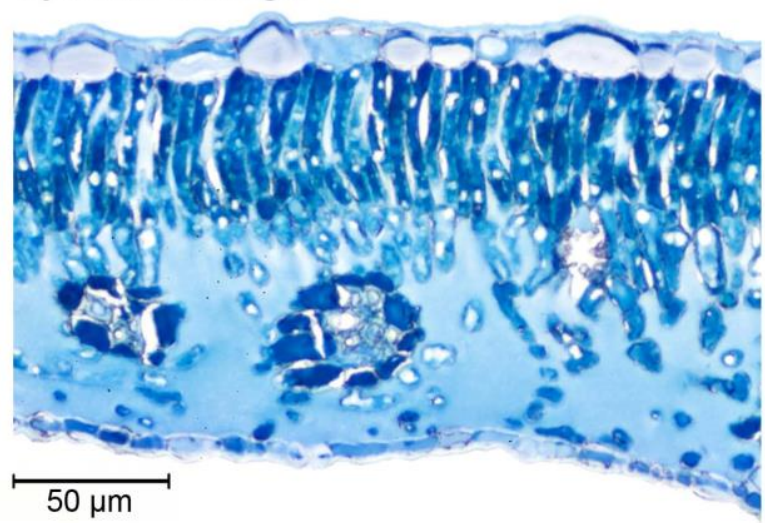

Fraxinus angustifolia

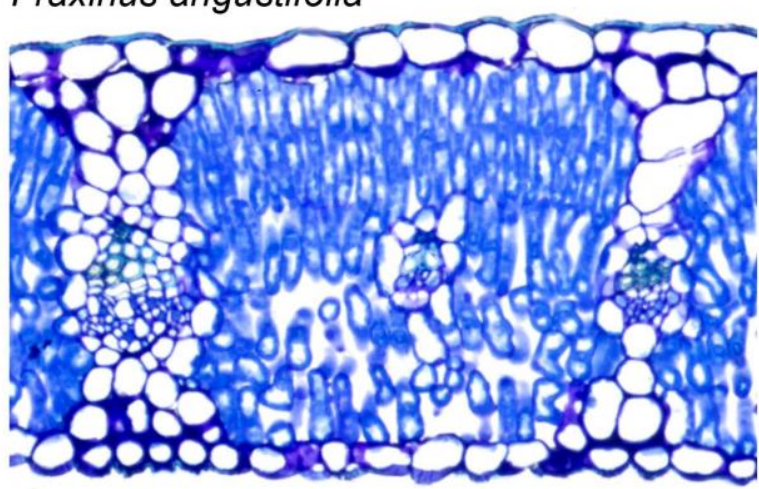

$50 \mu \mathrm{m}$
Crataegus monogyna

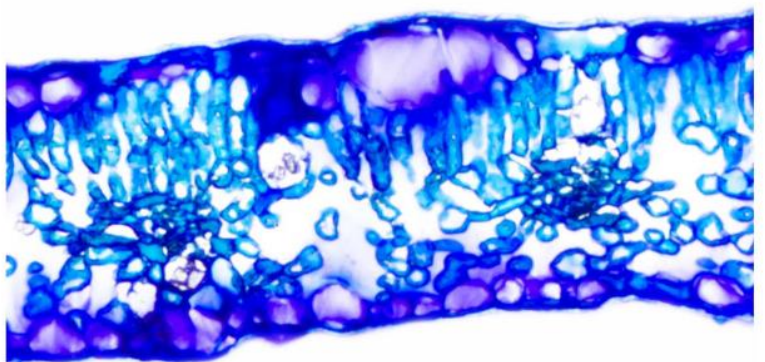

Ficus carica
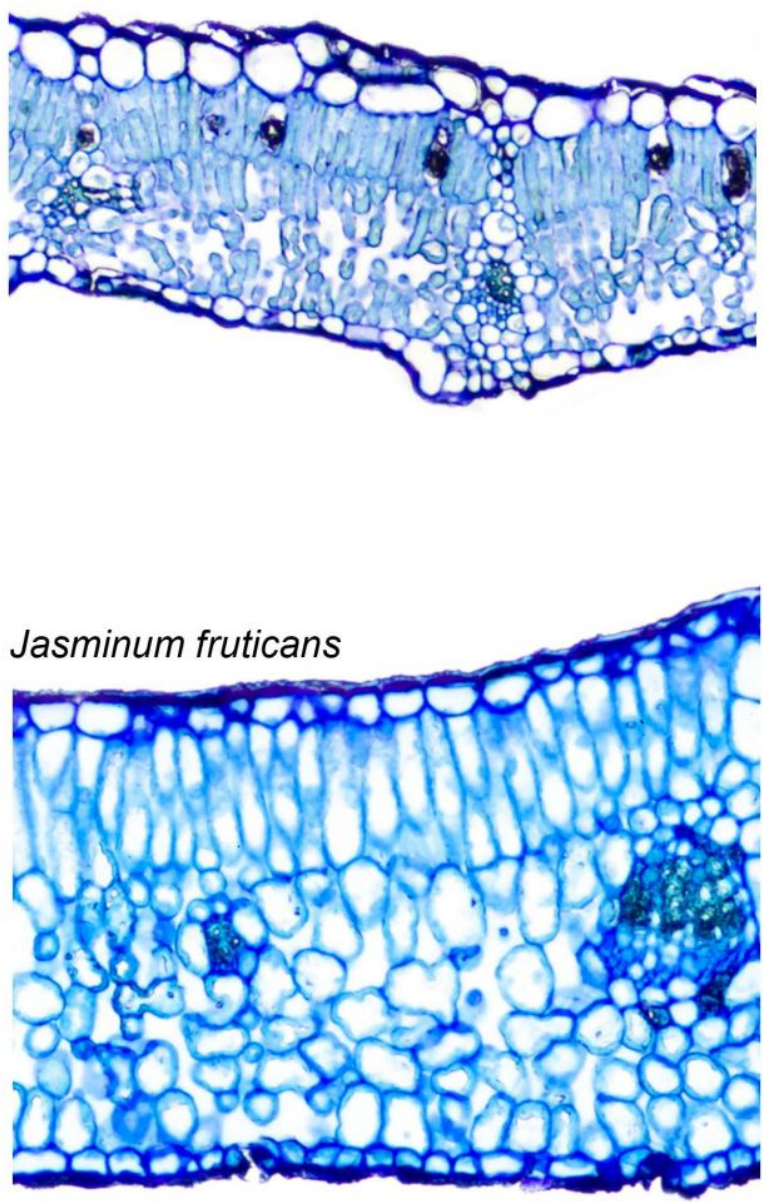
Lavandula stoechas

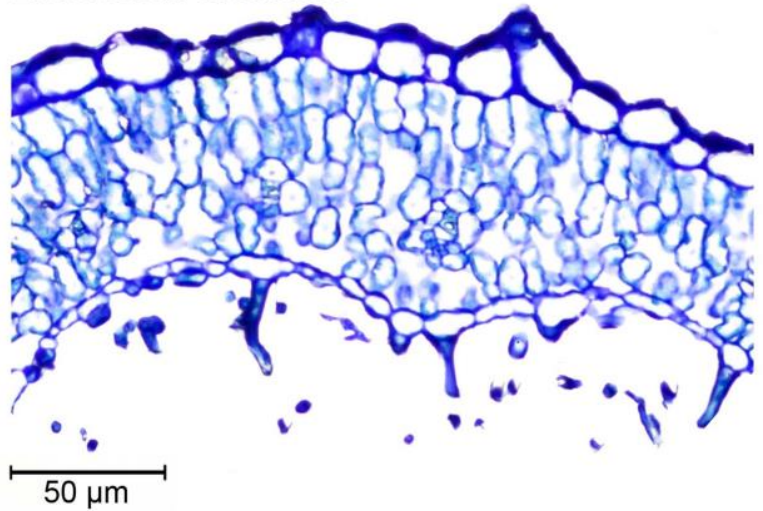

Nerium oleander

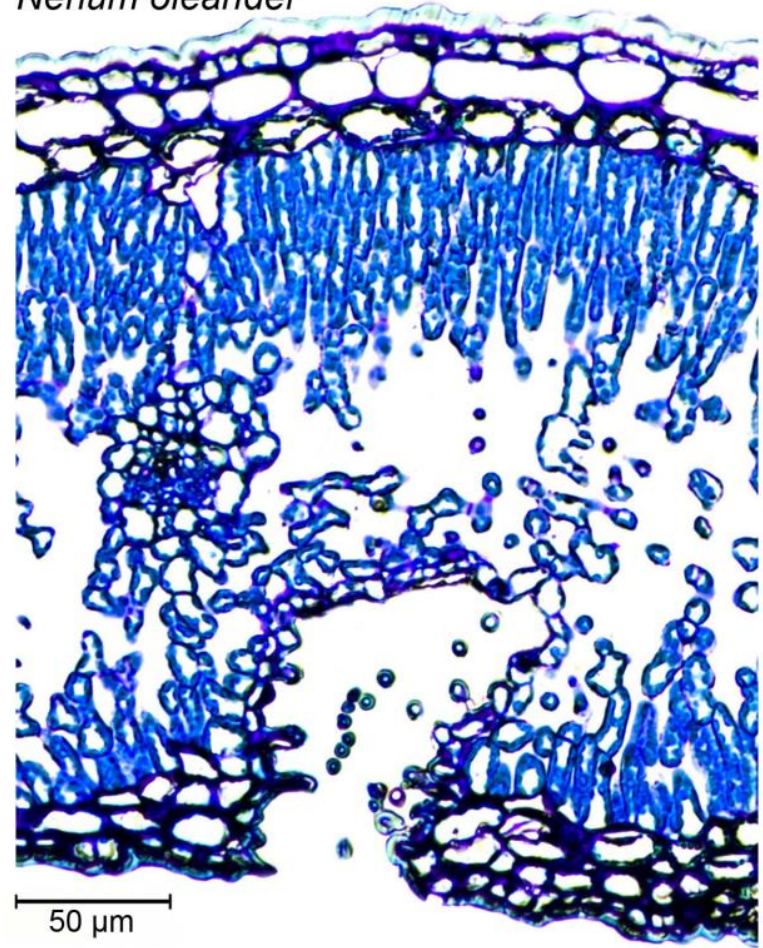

Phillyrea angustifolia

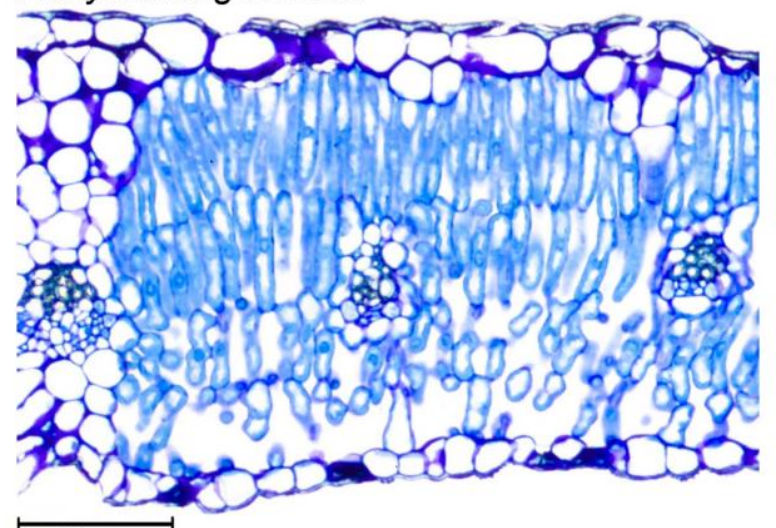

Myrtus communis

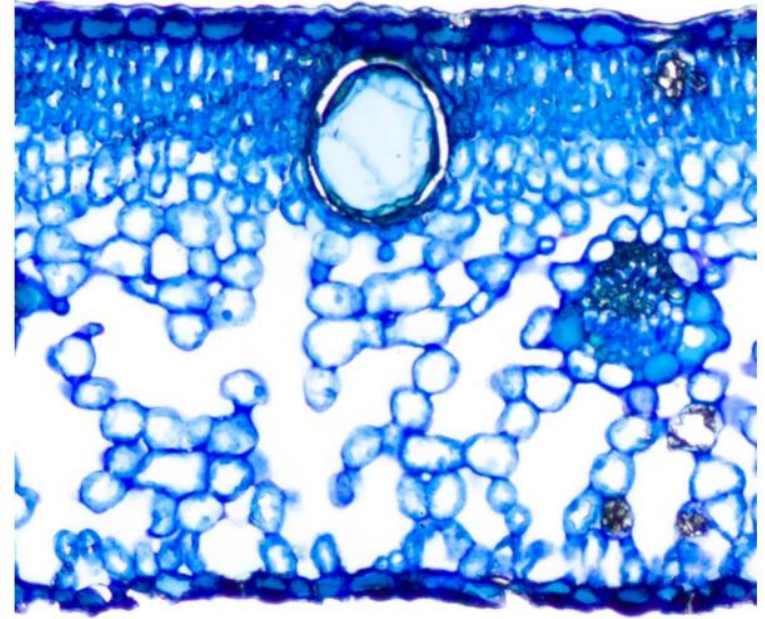

Phlomis purpurea

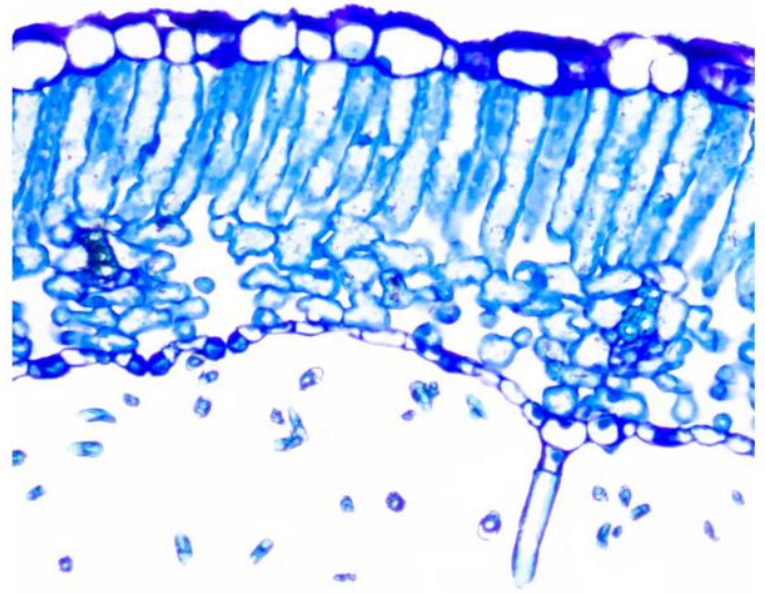

Phillyrea latifolia

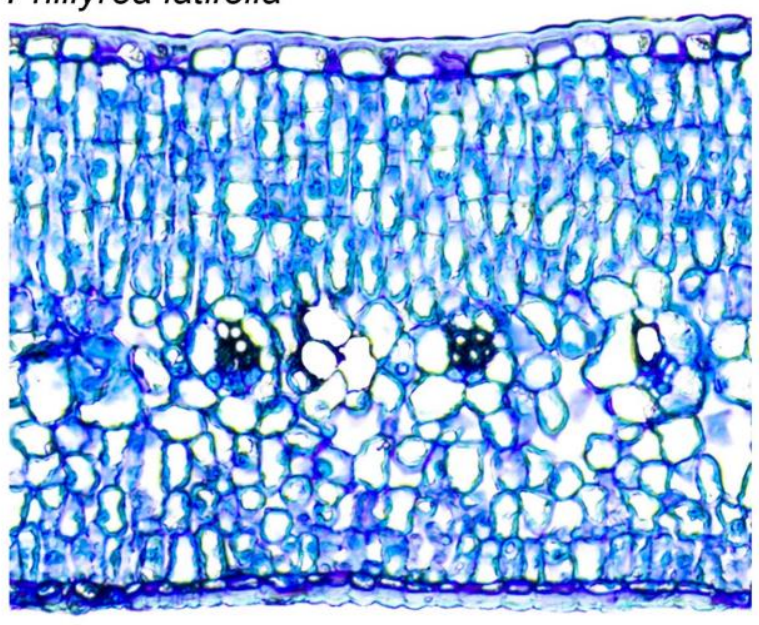


Pyrus pyraster

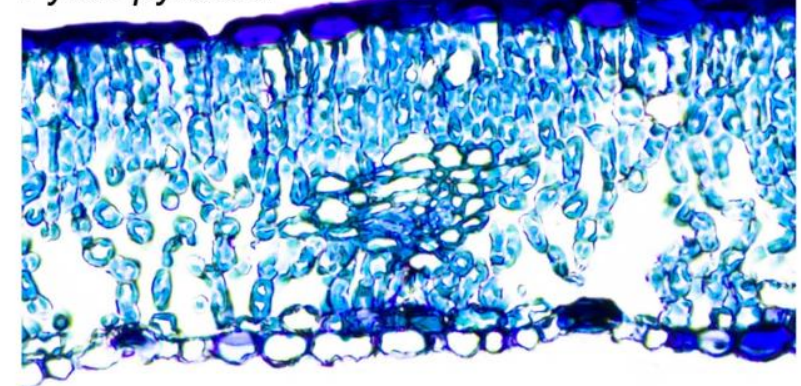

$50 \mu \mathrm{m}$

Pistacia terebinthus

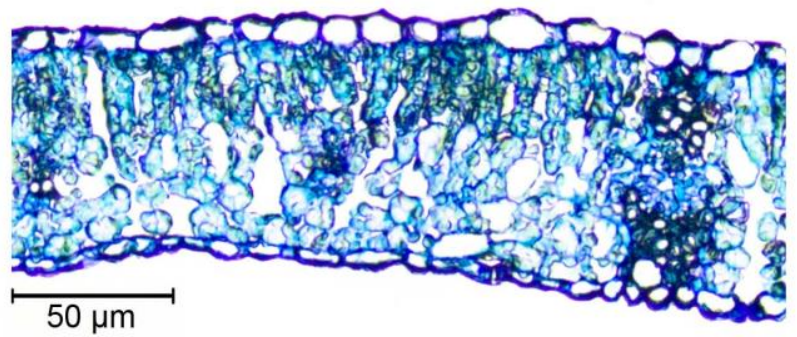

Quercus coccifera

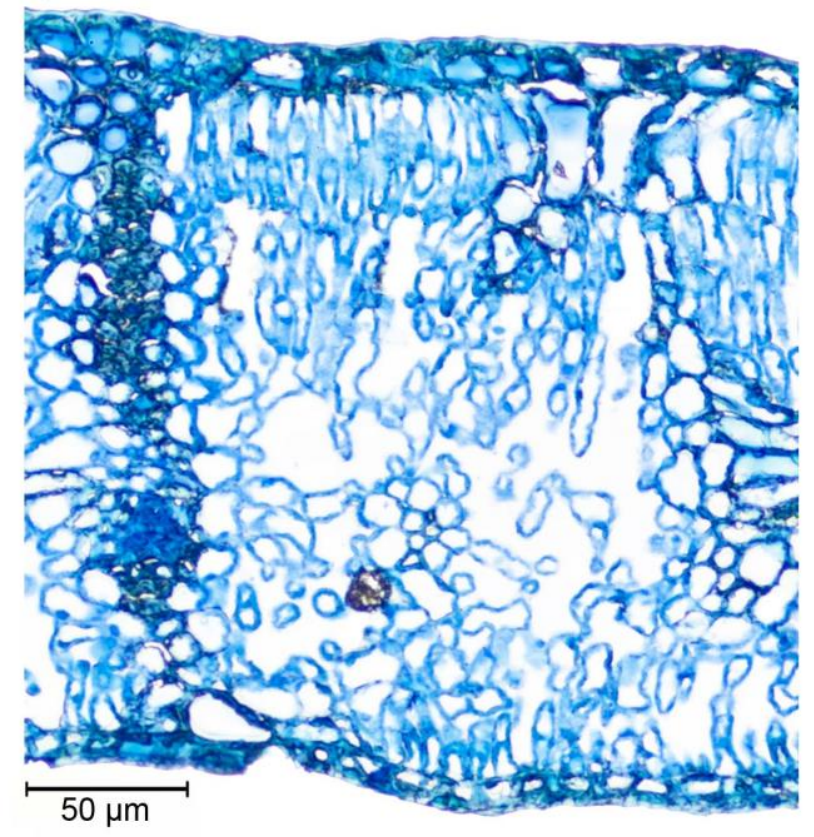

Pistacia lentiscus

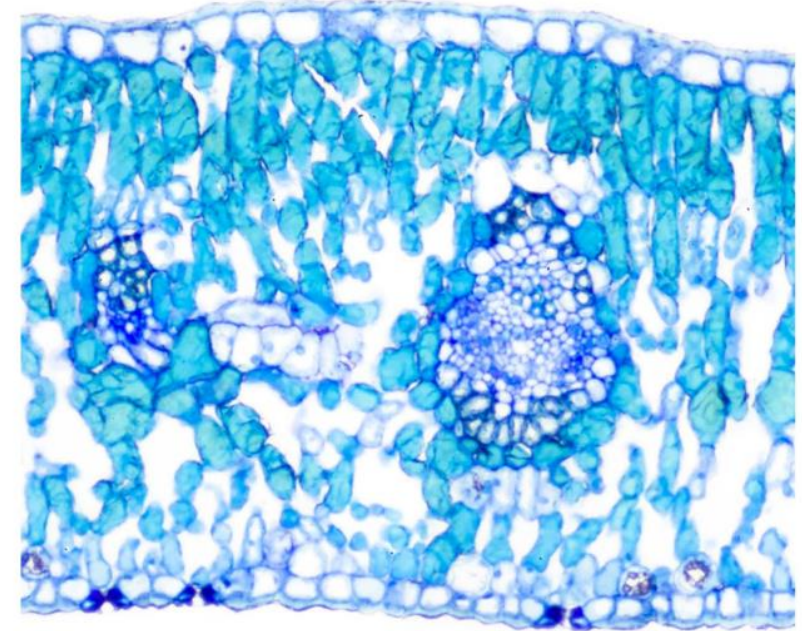

Populus alba

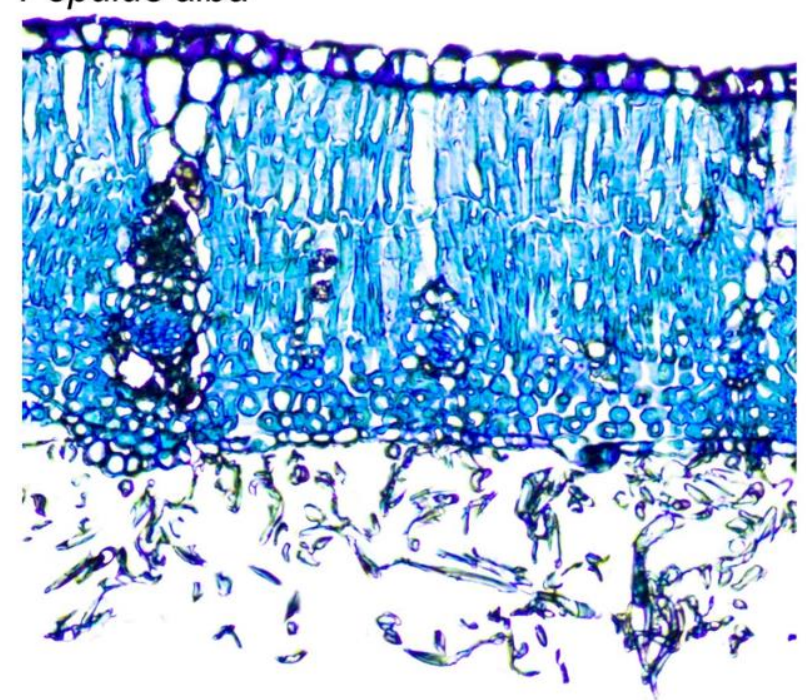

Quercus faginea

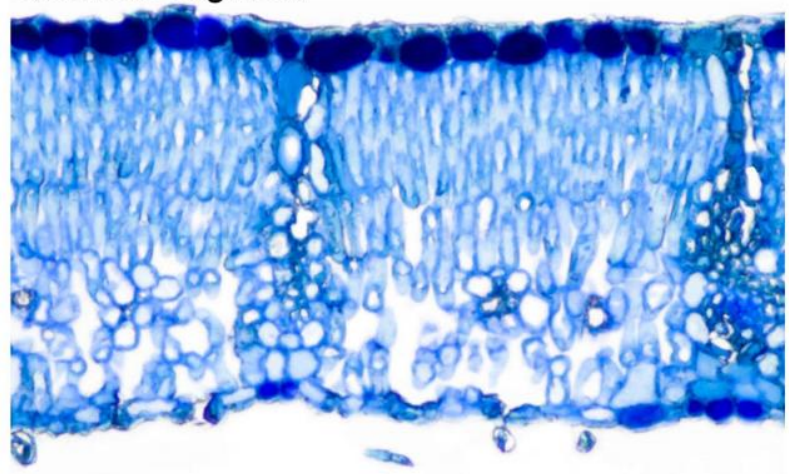



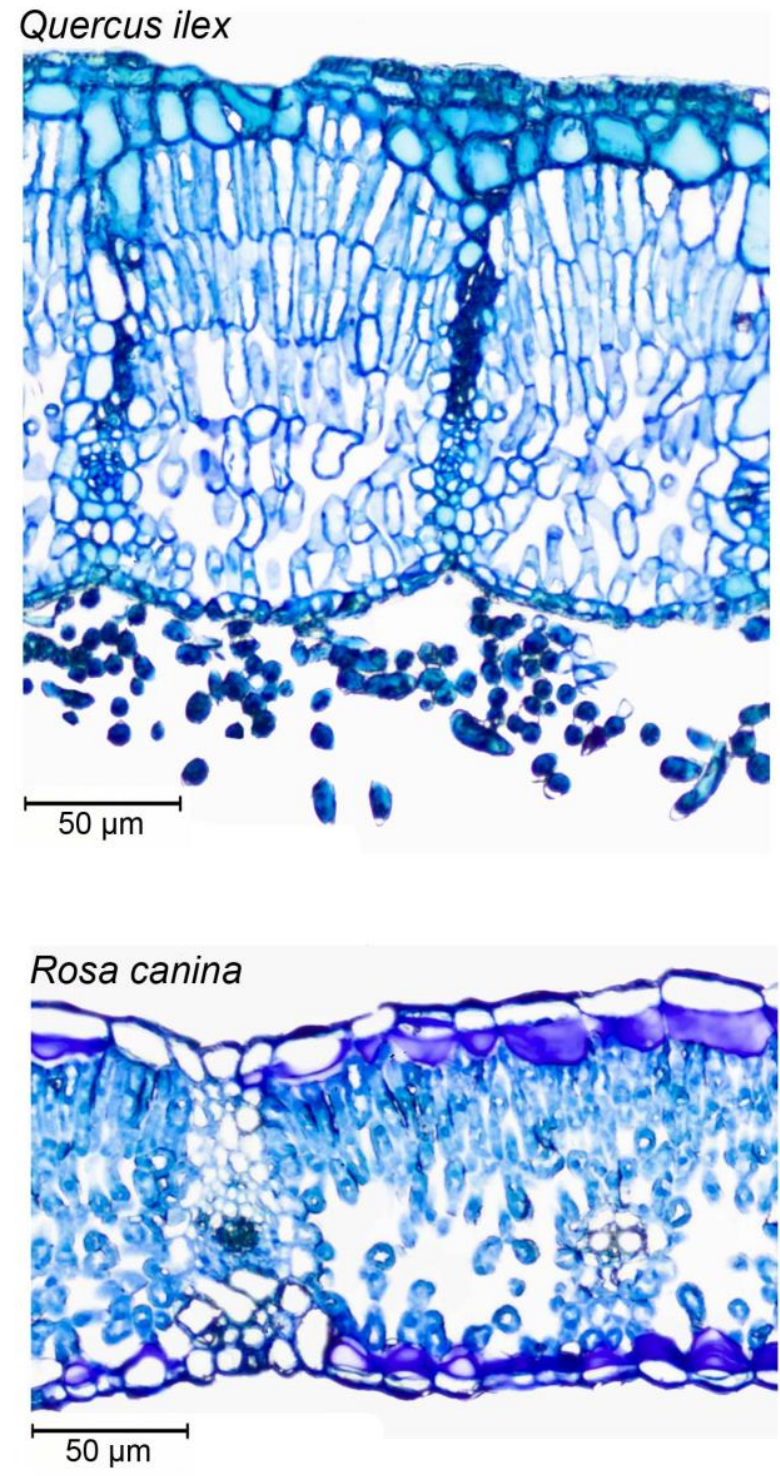

Rubus ulmifolius

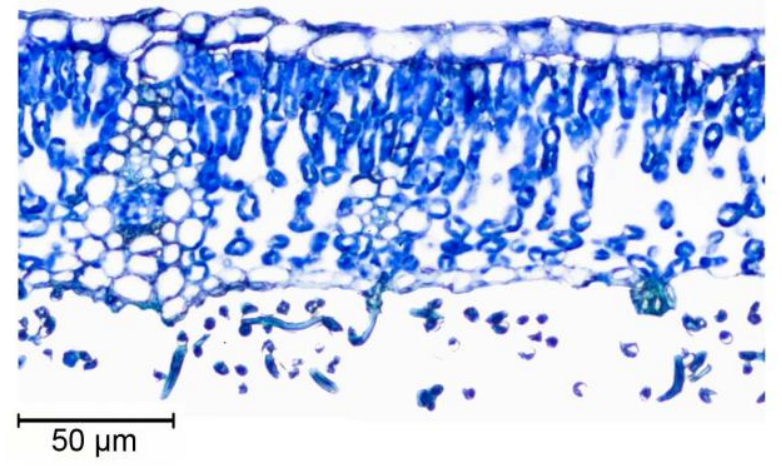

Rhamnus lycioides

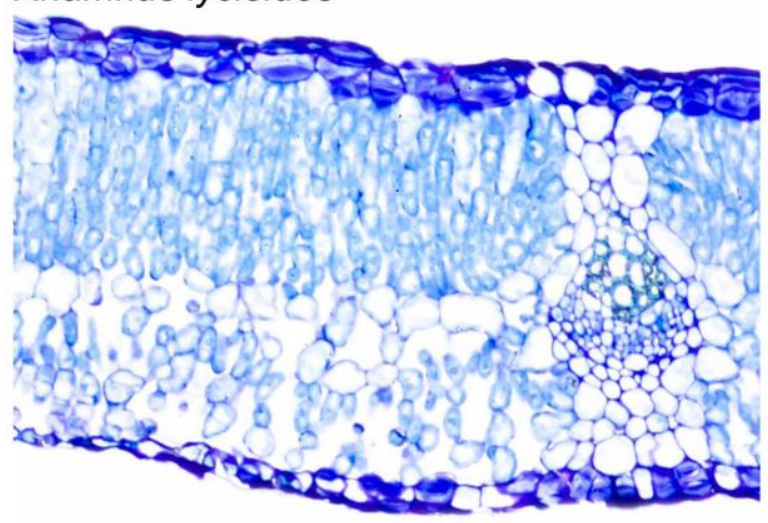

Rosmarinus officinalis
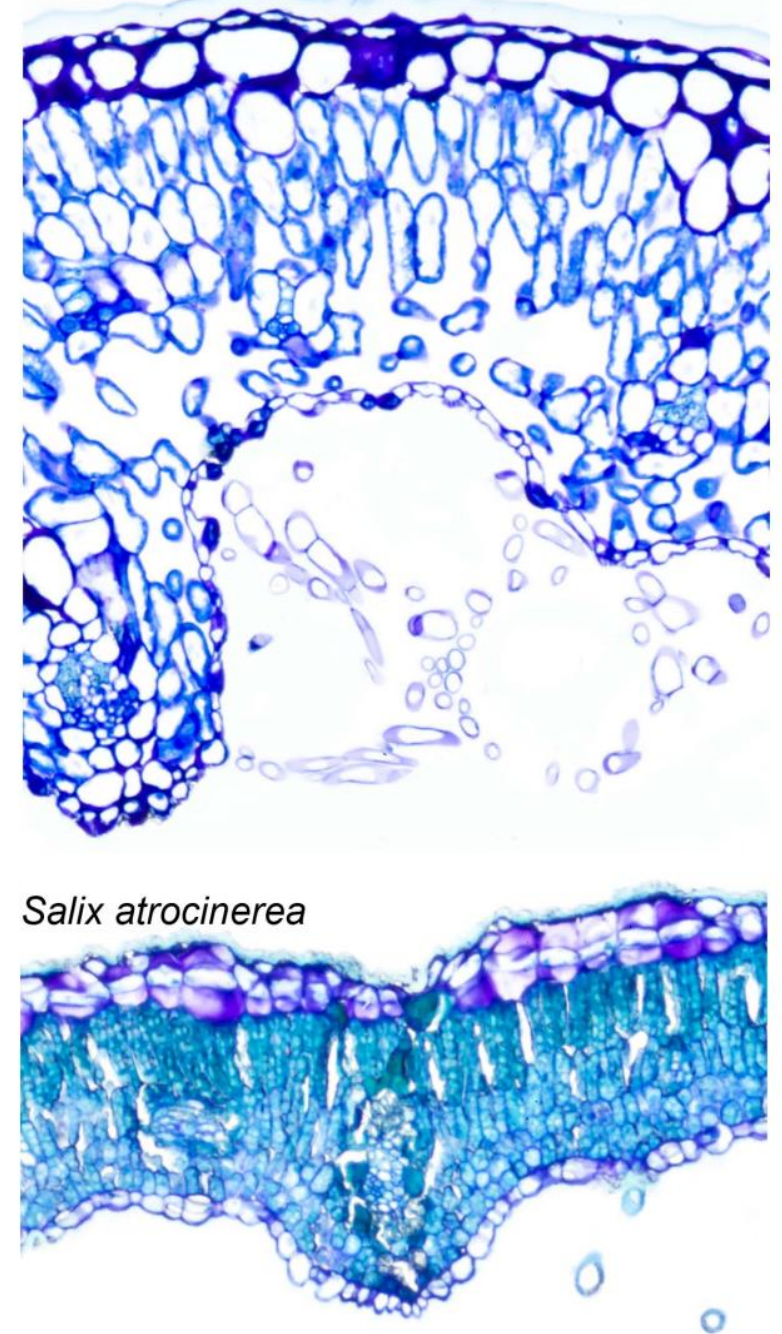
Smilax aspera

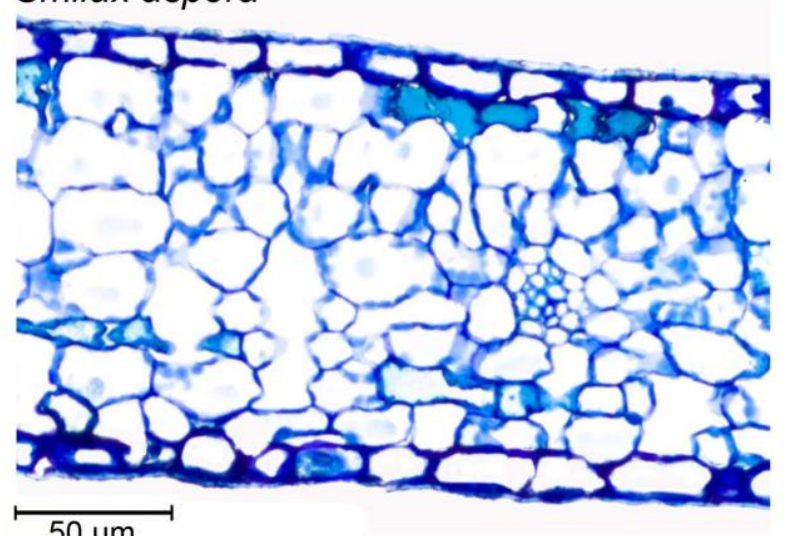

Ulmus minor

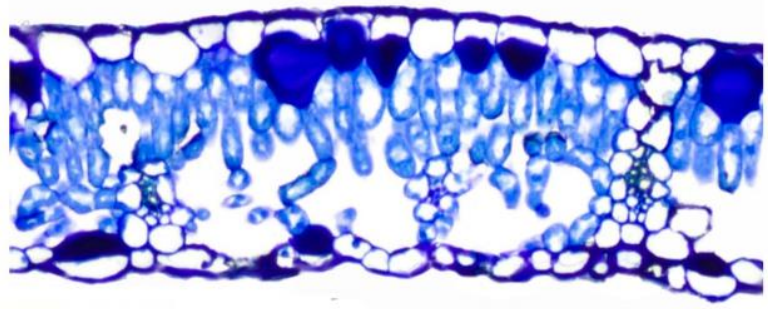

$50 \mu \mathrm{m}$
Teucrium fruticans

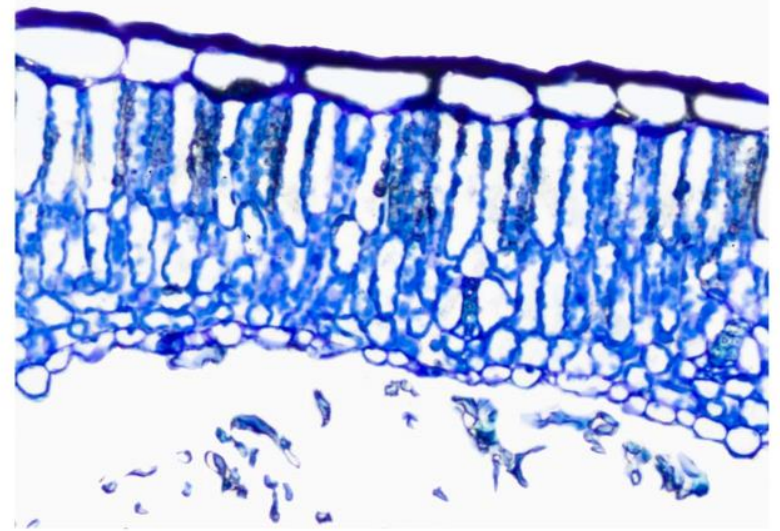

Vitis vinifera

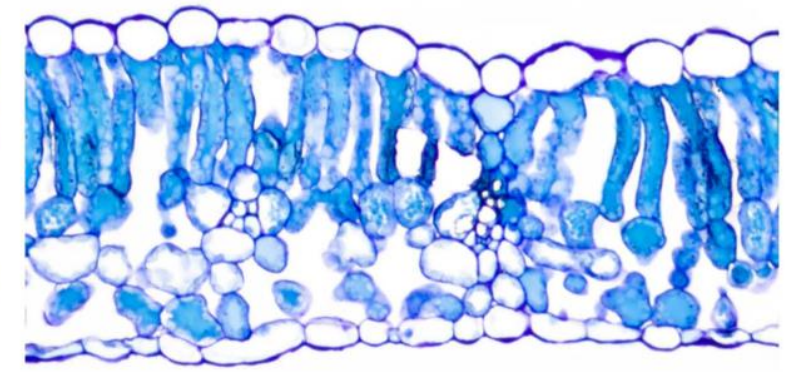


S2 Fig. The phylogenetic tree of the 34 studied species was obtained with the help of the Phylomatic program as implemented in Phylocom 4.2 and the reference phylogeny contained in R20120829.new (Webb, Ackerly \& Kembel 2008).

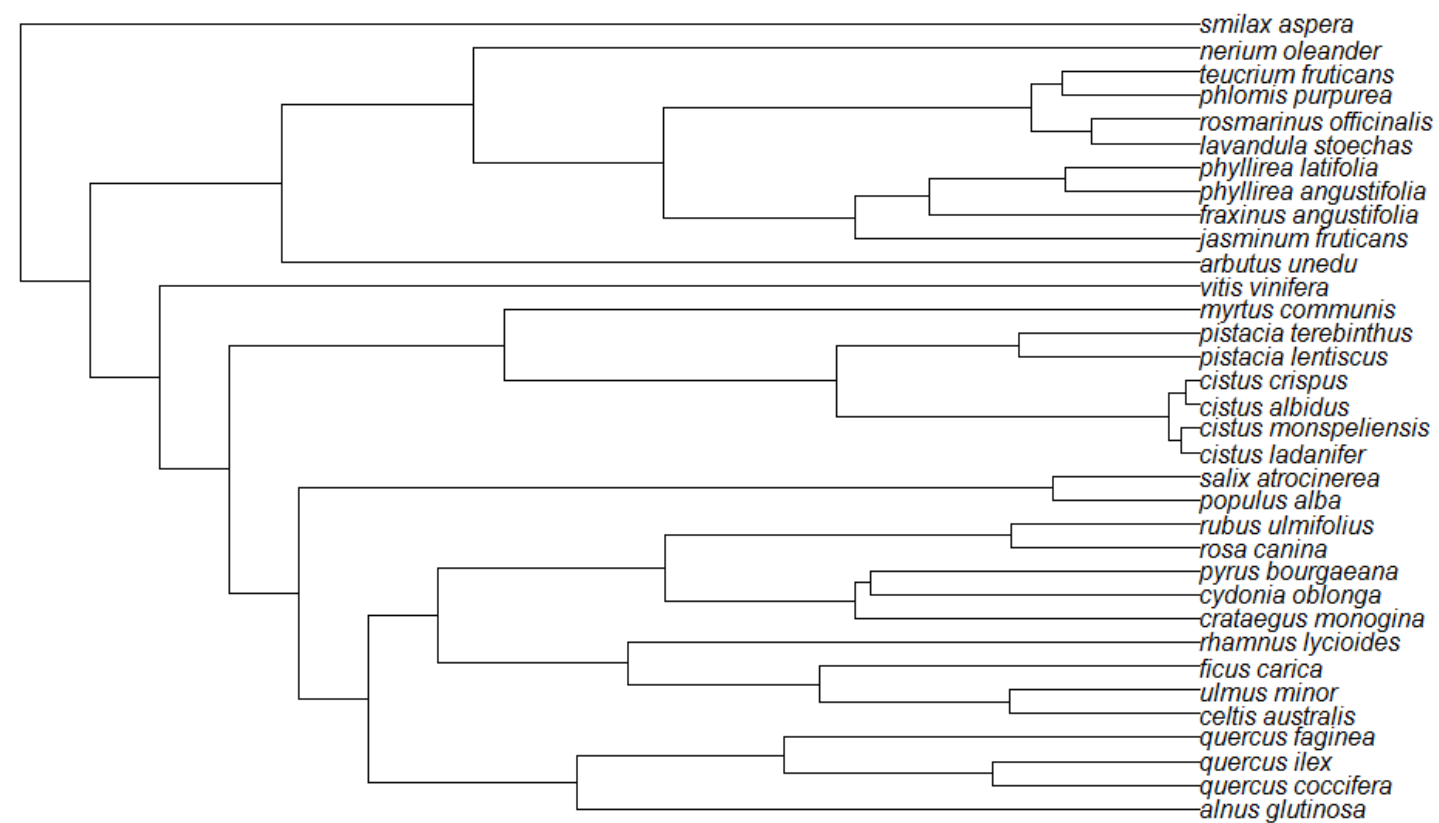


S1 Table. Species studied and areas where the samples were collected (see de la Riva et al 2015 for site description). T, tree; ST, small tree or arborescent shrub; S, shrub; D, deciduous; E, Evergreen.

\begin{tabular}{|c|c|c|c|c|c|c|}
\hline Species & Family & $\begin{array}{c}\text { Life } \\
\text { habit }\end{array}$ & $\begin{array}{l}\text { Leaf } \\
\text { habit }\end{array}$ & Sample site & Latitude & Longitude \\
\hline Alnus glutinosa & Betulaceae & $\mathrm{T}$ & $\mathrm{D}$ & Bejarano river & $37^{\circ} 56^{\prime} 90^{\prime \prime} \mathrm{N}$ & $4^{\circ} 53^{\prime} 60^{\prime \prime} \mathrm{W}$ \\
\hline Arbutus unedo & Ericaceae & ST & E & Las tonadas high hill & $38^{\circ} 1^{\prime} 32^{\prime \prime} \mathrm{N}$ & $5^{\circ} 1^{\prime} 65^{\prime \prime} \mathrm{W}$ \\
\hline Celtis australis & Cannabaceae & $\mathrm{T}$ & D & Pedroches stream & $37^{\circ} 55^{\prime} 73^{\prime \prime} \mathrm{N}$ & $4^{\circ} 46^{\prime} 16^{\prime \prime} \mathrm{W}$ \\
\hline Cistus albidus & Cistaceae & S & $\mathrm{E}$ & Oribe bajo high hill & $37^{\circ} 56^{\prime} 95^{\prime \prime} \mathrm{N}$ & $4^{\circ} 46^{\prime} 22^{\prime \prime} \mathrm{W}$ \\
\hline Cistus crispus & Cistaceae & s & E & Oribe bajo high hill & $37^{\circ} 56^{\prime} 95^{\prime \prime} \mathrm{N}$ & $4^{\circ} 46^{\prime} 22^{\prime \prime} \mathrm{W}$ \\
\hline Cistus ladanifer & Cistaceae & S & $E$ & Las tonadas high hill & $38^{\circ} 1^{\prime} 32^{\prime \prime} \mathrm{N}$ & $5^{\circ} 1^{\prime} 65^{\prime \prime} \mathrm{W}$ \\
\hline Cistus monspeliensis & Cistaceae & s & $\mathrm{E}$ & Las tonadas medium hill & $38^{\circ} 1^{\prime} 09^{\prime \prime} \mathrm{N}$ & $5^{\circ} 1^{\prime} 57^{\prime \prime} \mathrm{W}$ \\
\hline Crataegus monogyna & Rosaceae & ST & $\mathrm{D}$ & Pedroches stream & $37^{\circ} 55^{\prime} 73^{\prime \prime} \mathrm{N}$ & $4^{\circ} 46^{\prime} 16^{\prime \prime} \mathrm{W}$ \\
\hline Cydonia oblonga & Rosaceae & $\mathrm{T}$ & D & Las tonadas medium hill & $38^{\circ} 1^{\prime} 09^{\prime \prime} \mathrm{N}$ & $5^{\circ} 1^{\prime} 57^{\prime \prime} \mathrm{W}$ \\
\hline Ficus carica & Moraceae & $\mathrm{T}$ & $\mathrm{D}$ & Bejarano river & $37^{\circ} 56^{\prime} 90^{\prime \prime} \mathrm{N}$ & $4^{\circ} 53^{\prime} 60^{\prime \prime} \mathrm{W}$ \\
\hline Fraxinus angustifolia & Oleaceae & $\mathrm{T}$ & $\mathrm{D}$ & Orejon Stream & $38^{\circ} 1^{\prime} 73^{\prime \prime} \mathrm{N}$ & $5^{\circ} 1^{\prime} 54^{\prime \prime} \mathrm{W}$ \\
\hline Jasminum fruticans & Oleaceae & $S$ & $E$ & El Molinillo medium hill & $37^{\circ} 56^{\prime} 64^{\prime \prime} \mathrm{N}$ & $4^{\circ} 53^{\prime} 62^{\prime \prime} \mathrm{W}$ \\
\hline Lavandula stoechas & Lamiaceae & S & E & Oribe bajo medium hill & $37^{\circ} 55^{\prime} 83^{\prime \prime} \mathrm{N}$ & $\begin{array}{l}4^{\circ} 46^{\prime} \\
93^{\prime \prime} \mathrm{W}\end{array}$ \\
\hline Myrtus communis & Mirtaceae & $\mathrm{S}$ & $\mathrm{E}$ & Oribe bajo medium hill & $37^{\circ} 55^{\prime} 83^{\prime \prime} \mathrm{N}$ & $\begin{array}{l}4^{\circ} 46^{\prime} \\
93^{\prime \prime} \mathrm{W}\end{array}$ \\
\hline Nerium oleander & Apocynaceae & ST & E & Bejarano river & $37^{\circ} 56^{\prime} 90^{\prime \prime} \mathrm{N}$ & $4^{\circ} 53^{\prime} 60^{\prime \prime} \mathrm{W}$ \\
\hline Phlomis purpurea & Lamiaceae & $S$ & $\mathrm{E}$ & Oribe bajo high hill & $37^{\circ} 56^{\prime} 95^{\prime \prime} \mathrm{N}$ & $4^{\circ} 46^{\prime} 22^{\prime \prime} \mathrm{W}$ \\
\hline Phillyrea angustifolia & Oleaceae & ST & $\mathrm{E}$ & Las tonadas high hill & $38^{\circ} 1^{\prime} 32^{\prime \prime} \mathrm{N}$ & $5^{\circ} 1^{\prime} 65^{\prime \prime} \mathrm{W}$ \\
\hline Phillyrea latifolia & Oleaceae & ST & $\mathrm{E}$ & El Molinillo medium hill & $37^{\circ} 56^{\prime} 64^{\prime \prime} \mathrm{N}$ & $4^{\circ} 53^{\prime} 62^{\prime \prime} \mathrm{W}$ \\
\hline Pistacia lentiscus & Anacardiaceae & ST & $\mathrm{E}$ & Oribe bajo medium hill & $37^{\circ} 55^{\prime} 83^{\prime \prime} \mathrm{N}$ & $\begin{array}{l}4^{\circ} 46^{\prime} \\
93^{\prime \prime} \mathrm{W}\end{array}$ \\
\hline Pistacia terebinthus & Anacardiaceae & ST & D & El Molinillo medium hill & $37^{\circ} 56^{\prime} 64^{\prime \prime} \mathrm{N}$ & $4^{\circ} 53^{\prime} 62^{\prime \prime} \mathrm{W}$ \\
\hline Populus alba & Salicaceae & $\mathrm{T}$ & $\mathrm{D}$ & Orejon Stream & $38^{\circ} 1^{\prime} 73^{\prime \prime} \mathrm{N}$ & $5^{\circ} 1^{\prime} 54^{\prime \prime} \mathrm{W}$ \\
\hline Pyrus bourgaeana & Rosaceae & $\mathrm{T}$ & D & Las tonadas medium hill & $38^{\circ} 1^{\prime} 09^{\prime \prime} \mathrm{N}$ & $5^{\circ} 1^{\prime} 57^{\prime \prime} \mathrm{W}$ \\
\hline Quercus coccifera & Fagaceae & ST & E & Oribe bajo medium hill & $37^{\circ} 55^{\prime} 83^{\prime \prime} \mathrm{N}$ & $\begin{array}{l}4^{\circ} 46^{\prime} \\
93^{\prime \prime} \mathrm{W}\end{array}$ \\
\hline Quercus faginea & Fagaceae & $\mathrm{T}$ & D & El Molinillo medium hill & $37^{\circ} 56^{\prime} 64^{\prime \prime} \mathrm{N}$ & $4^{\circ} 53^{\prime} 62^{\prime \prime} \mathrm{W}$ \\
\hline $\begin{array}{l}\text { Quercus ilex } \\
\text { spp.ballota }\end{array}$ & Fabaceae & $\mathrm{T}$ & $\mathrm{E}$ & Oribe bajo medium hill & $37^{\circ} 55^{\prime} 83^{\prime \prime} \mathrm{N}$ & $\begin{array}{l}4^{\circ} 46^{\prime} \\
93^{\prime \prime} \mathrm{W}\end{array}$ \\
\hline Rhamnus lycioides & Rhamnaceae & $S$ & E & Pedroches stream & $37^{\circ} 55^{\prime} 73^{\prime \prime} \mathrm{N}$ & $4^{\circ} 46^{\prime} 16^{\prime \prime} \mathrm{W}$ \\
\hline Rosa canina & Rosaceae & S & $\mathrm{D}$ & Las tonadas medium hill & $38^{\circ} 1^{\prime} 09^{\prime \prime} \mathrm{N}$ & $5^{\circ} 1^{\prime} 57^{\prime \prime} \mathrm{W}$ \\
\hline Rosmarinus officinalis & Lamiaceae & s & E & El Molinillo high hill & $37^{\circ} 56^{\prime} 64^{\prime \prime} \mathrm{N}$ & $4^{\circ} 53^{\prime} 62^{\prime \prime} \mathrm{W}$ \\
\hline Rubus ulmifolius & Rosaceae & s & $\mathrm{E}$ & Las tonadas medium hill & $38^{\circ} 1^{\prime} 09^{\prime \prime} \mathrm{N}$ & $5^{\circ} 1^{\prime} 57^{\prime \prime} \mathrm{W}$ \\
\hline Salix atrocinerea & Salicaceae & $\mathrm{T}$ & $\mathrm{D}$ & Orejon Stream & $38^{\circ} 1^{\prime} 73^{\prime \prime} \mathrm{N}$ & $5^{\circ} 1^{\prime} 54^{\prime \prime} \mathrm{W}$ \\
\hline Smilax aspera & Smilacaceae & $\mathrm{S}$ & E & El Molinillo medium hill & $37^{\circ} 56^{\prime} 64^{\prime \prime} \mathrm{N}$ & $4^{\circ} 53^{\prime} 62^{\prime \prime} \mathrm{W}$ \\
\hline Teucrium fruticans & Lamiaceae & s & $\mathrm{E}$ & El Molinillo high hill & $37^{\circ} 56^{\prime} 81^{\prime \prime} \mathrm{N}$ & $4^{\circ} 53^{\prime} 44^{\prime \prime} \mathrm{W}$ \\
\hline Ulmus minor & Ulmaceae & $\mathrm{T}$ & $\mathrm{D}$ & Bejarano river & $37^{\circ} 56^{\prime} 90^{\prime \prime} \mathrm{N}$ & $4^{\circ} 53^{\prime} 60^{\prime \prime} \mathrm{W}$ \\
\hline Vitis vinifera & Vitaceae & $\mathrm{s}$ & $\mathrm{D}$ & Pedroches stream & $37^{\circ} 55^{\prime} 73^{\prime \prime} \mathrm{N}$ & $4^{\circ} 46^{\prime} 16^{\prime \prime} \mathrm{W}$ \\
\hline
\end{tabular}


S2 Table. Location of the sampling sites. The annual rainfall and the soil water content is shown. Sites are ordered by soil water content.

\begin{tabular}{llccr}
\hline \multicolumn{1}{c}{ Sample site } & \multicolumn{1}{c}{ Latitude } & Longitude & $\begin{array}{c}\text { Rainfall } \\
(\mathbf{m m})\end{array}$ & $\begin{array}{c}\text { SWS } \\
\left(\mathbf{L ~ ~ m ^ { - 2 }}\right)\end{array}$ \\
\hline Las Tonadas high hill & $38^{\circ} 1^{\prime} 32^{\prime \prime} \mathrm{N}$ & $5^{\circ} 1^{\prime} 65^{\prime \prime} \mathrm{W}$ & 668 & 25.61 \\
El Molinillo high hill & $37^{\circ} 56^{\prime} 64^{\prime \prime} \mathrm{N}$ & $4^{\circ} 53^{\prime} 62^{\prime \prime} \mathrm{W}$ & 647 & 30.65 \\
El Molinillo medium hill & $37^{\circ} 56^{\prime} 64^{\prime \prime} \mathrm{N}$ & $4^{\circ} 53^{\prime} 62^{\prime \prime} \mathrm{W}$ & 647 & 49.26 \\
Las Tonadas medium hill & $38^{\circ} 1^{\prime} 09^{\prime \prime} \mathrm{N}$ & $5^{\circ} 1^{\prime} 57^{\prime \prime} \mathrm{W}$ & 668 & 50.83 \\
Oribe bajo high hill & $37^{\circ} 56^{\prime} 95^{\prime \prime} \mathrm{N}$ & $4^{\circ} 46^{\prime} 22^{\prime \prime} \mathrm{W}$ & 638 & 62.34 \\
Oribe bajo medium hill & $37^{\circ} 55^{\prime} 83^{\prime \prime} \mathrm{N}$ & $4^{\circ} 46^{\prime} 93^{\prime \prime} \mathrm{W}$ & 638 & 65.38 \\
Orejon Stream & $38^{\circ} 1^{\prime} 73^{\prime \prime} \mathrm{N}$ & $5^{\circ} 1^{\prime} 54^{\prime \prime} \mathrm{W}$ & 668 & 80.53 \\
Pedroches stream & $37^{\circ} 55^{\prime} 73^{\prime \prime} \mathrm{N}$ & $4^{\circ} 46^{\prime} 16^{\prime \prime} \mathrm{W}$ & 638 & 81.19 \\
Bejarano river & $37^{\circ} 56^{\prime} 90^{\prime \prime} \mathrm{N}$ & $4^{\circ} 53^{\prime} 60^{\prime \prime} \mathrm{W}$ & 647 & 93.63 \\
\hline
\end{tabular}


S3 Table. Mean \pm SD values of the leaf traits for deciduous and evergreens. The data of anatomical tissues are presented in absolute values (tissue thickness) and percentage of the different tissues (i.e. tissue volumes fractions). The significance $(\mathrm{P})$ of the comparison between deciduous and evergreen species following a phylogenetic generalized least squares model (PGLS) is presented. The level of significance is expressed as follows: a $0.05 \leq \mathrm{P}<0.10, * P<0.05$, ** $P<0.01$, *** $P<0.001$.

\begin{tabular}{|c|c|c|c|}
\hline & Deciduous & Evergreen & $P$ \\
\hline LMA ( m m² $^{-2}$ & $67.09 \pm 27.78$ & $102.90 \pm 43.00$ & $* *$ \\
\hline $\mathbf{L V A}\left(\mathbf{m L ~ \mathbf { m } ^ { - 2 }}\right)$ & $132.08 \pm 27.26$ & $180.16 \pm 56.36$ & $* *$ \\
\hline $\mathrm{LD}\left(\mathrm{g} \mathrm{mL}^{-1}\right)$ & $0.49 \pm 0.15$ & $0.57 \pm 0.17$ & $\mathrm{~ns}$ \\
\hline Epidermis VA $\left(\mathrm{mL} \mathrm{m}^{-2}\right)$ & $28.56 \pm 6.29$ & $32.16 \pm 17.45$ & $\mathrm{~ns}$ \\
\hline Mesophyll VA $\left(\mathrm{mL} \mathrm{m} \mathbf{m}^{-2}\right)$ & $69.78 \pm 23.91$ & $103.10 \pm 31.33$ & $* * *$ \\
\hline Air spaces VA $\left(\mathbf{m L ~ m} \mathbf{m}^{-2}\right)$ & $19.50 \pm 5.25$ & $24.74 \pm 12.68$ & $\mathrm{~ns}$ \\
\hline Vas+ Scl VA $\left(\mathbf{m L ~ m} \mathbf{~ m}^{-2}\right)$ & $13.68 \pm 7.69$ & $18.99 \pm 17.48$ & $\mathrm{~ns}$ \\
\hline Mesophyll (\%) & $51.30 \pm 8.97$ & $57.80 \pm 9.88$ & $*$ \\
\hline Epidermis (\%) & $22.52 \pm 5.49$ & $18.20 \pm 5.70$ & $*$ \\
\hline Air spaces $(\%)$ & $10.86 \pm 5.66$ & $10.05 \pm 4.64$ & $\mathrm{~ns}$ \\
\hline Vas + Scl (\%) & $14.85 \pm 6.33$ & $13.28 \pm 7.94$ & $\mathrm{~ns}$ \\
\hline LNC (\%) & $2.59 \pm 0.52$ & $1.91 \pm 0.48$ & $* * *$ \\
\hline $\mathrm{LCC}(\%)$ & $47.30 \pm 3.36$ & $48.97 \pm 1.80$ & $\mathrm{a}$ \\
\hline
\end{tabular}


S4 Table. Pearson correlation coefficients between leaf traits for: A) all species data (above diagonal) and phylogenetically independent contrasts (below diagonal) and B) for deciduous species data (above diagonal) and for evergreen species (below diagonal). The level of significance is expressed as follows: * $P<0.05$, ** $P<0.01$, *** $P<0.001$.

\begin{tabular}{|c|c|c|c|c|c|c|c|c|c|}
\hline A) & LMA & LVA & LD & Epi VA & Mes VA & $\begin{array}{c}\text { Vas + Scl } \\
\text { VA }\end{array}$ & Air VA & $\mathrm{LCC}$ & LNC \\
\hline LMA & & $0.71 * * *$ & $0.79 * * *$ & 0.28 & $0.64 * * *$ & 0.27 & $0.63 * * *$ & $0.50 * *$ & $-0.49 * *$ \\
\hline LVA & $0.33^{*}$ & & 0.18 & $0.63 * *$ & $0.84 * * *$ & $0.59 * *$ & $0.62 * *$ & $0.38 *$ & $-0.47 * *$ \\
\hline LD & $0.91 * * *$ & 0.22 & & -0.07 & 0.22 & $0.36^{*}$ & -0.15 & $0.43 * *$ & $-0.36^{*}$ \\
\hline Epi VA & $0.69 * * *$ & $0.33^{*}$ & $0.51 * *$ & & 0.27 & $0.37 *$ & $0.46^{* *}$ & 0.01 & -0.20 \\
\hline Mes VA & $0.67 * * *$ & $0.37 *$ & $0.41 *$ & 0.46 & & 0.24 & 0.33 & $0.38 *$ & $-0.42 * *$ \\
\hline $\begin{array}{l}\text { Vas }+ \\
\text { Scl VA }\end{array}$ & $0.77 * * *$ & $0.57 * * *$ & $0.66 * * *$ & $0.60 * * *$ & $0.37^{*}$ & & 0.29 & $0.35^{*}$ & -0.31 \\
\hline Air VA & $-0.48 * *$ & -0.04 & $-0.65 * * *$ & -0.11 & -0.15 & 0.29 & & 0.18 & -0.28 \\
\hline LCC & 0.12 & $0.49 * *$ & 0.09 & -0.08 & 0.16 & $0.35^{*}$ & 0.12 & & $-0.50 * *$ \\
\hline LNC & $-0.58 * * *$ & $-0.38 *$ & $-0.43^{*}$ & $-0.43^{*}$ & $-0.49 * *$ & $-0.49 * *$ & 0.24 & $-0.50 * *$ & \\
\hline
\end{tabular}

\begin{tabular}{lccccccccc}
\hline B) & LMA & LVA & LD & Epi VA & Mes VA & $\begin{array}{c}\text { Vas + Scl } \\
\text { VA }\end{array}$ & Air VA & LCC & LNC \\
\cline { 2 - 9 } LMA & & $0.79^{* *}$ & $0.91^{* * *}$ & -0.01 & $0.80^{* *}$ & $0.53^{*}$ & -0.32 & $0.62^{*}$ & -0.49 \\
LVA & $0.61^{* *}$ & & 0.48 & 0.23 & $0.95^{* * *}$ & $0.57 *$ & -0.23 & $0.55^{*}$ & -0.35 \\
LD & $0.75^{* * *}$ & -0.02 & & -0.09 & 0.51 & 0.39 & -0.27 & 0.51 & $-0.55^{*}$ \\
Epi VA & 0.31 & $0.71^{* * *}$ & -0.12 & & 0.04 & -0.28 & 0.29 & -0.05 & -0.46 \\
Mes VA & $0.46^{*}$ & $0.77^{* * *}$ & -0.06 & 0.29 & & 0.50 & -0.41 & $0.62^{*}$ & -0.29 \\
Vas + & $0.65^{* *}$ & $0.58^{* *}$ & 0.34 & 0.43 & 0.11 & & -0.43 & -0.01 & -0.01 \\
Scl VA & & & & & & & 0.11 & 0.03 \\
Air VA & 0.27 & $0.711^{* * *}$ & -0.22 & $0.47 *$ & 0.39 & 0.34 & & -0.44 \\
LCC & 0.38 & 0.21 & 0.31 & 0.01 & -0.01 & $0.62 * *$ & 0.14 & & -0.41 \\
LNC & -0.28 & -0.28 & -0.11 & -0.11 & -0.14 & -0.36 & -0.25 & -0.41 & \\
\hline
\end{tabular}


S5 Table. Linear regressions between leaf density (LD) with anatomical tissues, expressed as tissue volume fractions). The level of significance is expressed as follows: a $0.05 \leq P<0.10, * P<0.05$.

\begin{tabular}{|c|c|c|c|c|c|c|}
\hline & \multicolumn{6}{|c|}{ LD } \\
\hline & \multicolumn{2}{|r|}{ All } & \multicolumn{2}{|c|}{ Deciduous } & \multicolumn{2}{|c|}{ Evergreen } \\
\hline & Rel & $\mathrm{R}^{2}$ & Rel & $\mathrm{R}^{2}$ & Rel & $\mathrm{R}^{2}$ \\
\hline Epidermis (\%) & - & $0.11 *$ & & $\mathrm{~ns}$ & & ns \\
\hline Mesophyll (\%) & & ns & + & $0.24 \mathrm{a}$ & & ns \\
\hline $\operatorname{Vas}+\operatorname{Scl}(\%)$ & & ns & & ns & + & $0.16 \mathrm{a}$ \\
\hline Air spaces (\%) & - & $0.11 *$ & & $\mathrm{~ns}$ & & ns \\
\hline
\end{tabular}


S6 Table. Mean data of leaf traits and soil water content (SWC) of the sites where species were collected.

\begin{tabular}{|c|c|c|c|c|c|c|c|c|c|c|}
\hline Species & $\begin{array}{c}\text { LMA } \\
\left(\mathrm{g} \mathrm{m}^{-2}\right)\end{array}$ & 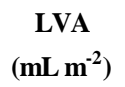 & $\begin{array}{c}\text { LD } \\
(\mathrm{g} \mathrm{mL}-1)\end{array}$ & $\begin{array}{c}\text { Epidermis } \\
\text { VA }\left(\mathbf{m L ~ m}^{-2}\right)\end{array}$ & 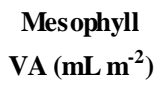 & $\begin{array}{c}\text { Air spaces } \\
\text { VA }\left(m L ~ m^{-2}\right)\end{array}$ & $\begin{array}{c}\text { Vas + Scl VA } \\
\left(\mathrm{mL} \mathrm{m}^{-2}\right)\end{array}$ & $\mathbf{L N}(\%)$ & $\mathrm{LC}(\%)$ & $\begin{array}{c}\text { SWC } \\
(\mathrm{g} \mathrm{m}-2)\end{array}$ \\
\hline Alnus glutinosa & 27.8 & 89.1 & 0.31 & 23.1 & 34.4 & 24 & 7.4 & 3.46 & 48.9 & 93.63 \\
\hline Arbutus unedo & 120.3 & 219.5 & 0.55 & 47.8 & 95.5 & 42.8 & 33.4 & 1.63 & 50 & 25.61 \\
\hline Celtis australis & 56.8 & 118.7 & 0.48 & 30.9 & 61.6 & 11.5 & 12.3 & 3.03 & 44.8 & 81.19 \\
\hline Cistus albidus & 92.4 & 130.3 & 0.71 & 23.4 & 74.5 & 10.4 & 17.8 & 1.97 & 49.2 & 62.34 \\
\hline Cistus crispus & 86.6 & 142.7 & 0.61 & 19.5 & 92.9 & 14.9 & 14.2 & 1.9 & 49.2 & 62.34 \\
\hline Cistus ladanifer & 207.7 & 214.9 & 0.97 & 46 & 121.5 & 6.7 & 40.7 & 1.51 & 48.8 & 25.61 \\
\hline Cistus monspeliensis & 86.1 & 160.5 & 0.54 & 31.8 & 86.1 & 21.3 & 19.6 & 2.14 & 49.2 & 50.83 \\
\hline Crataegus monogyna & 73.9 & 130.1 & 0.57 & 41.4 & 58 & 19.9 & 10.7 & 1.61 & 49.1 & 81.19 \\
\hline Cydonia oblonga & 88 & 150.8 & 0.58 & 28.5 & 84.1 & 12.8 & 25.4 & 2.3 & 49.4 & 50.83 \\
\hline Ficus carica & 31 & 80.4 & 0.38 & 20.2 & 28.8 & 6 & 24.7 & 3.25 & 39.5 & 93.63 \\
\hline Fraxinus angustifolia & 70.6 & 168.7 & 0.42 & 28 & 93.6 & 15.1 & 32 & 2.83 & 46.9 & 80.53 \\
\hline Jasminum fruticans & 78.8 & 197.9 & 0.4 & 29.8 & 152.8 & 9.7 & 5.6 & 1.91 & 46.7 & 49.26 \\
\hline Lavandula stoechas & 31 & 74.8 & 0.42 & 23 & 38.2 & 8.5 & 5.1 & 1.43 & 46.7 & 65.38 \\
\hline Myrtus communis & 91.8 & 228.7 & 0.4 & 23.9 & 140.6 & 36.8 & 18.7 & 1.47 & 46.8 & 65.38 \\
\hline Nerium oleander & 122.7 & 328.8 & 0.37 & 99.4 & 132.7 & 38.5 & 55.2 & 1.7 & 49.2 & 93.63 \\
\hline Phlomis purpurea & 110 & 136.1 & 0.81 & 29.3 & 85.2 & 11.2 & 10.4 & 2.53 & 47.3 & 62.34 \\
\hline Phillyrea angustifolia & 143.8 & 179.6 & 0.8 & 30.6 & 95.8 & 20.7 & 32.5 & 1.95 & 51.1 & 25.61 \\
\hline Phillyrea latifolia & 107.6 & 191.5 & 0.56 & 23.4 & 154.7 & 7.1 & 6.3 & 1.66 & 50.3 & 49.26 \\
\hline Pistacia lentiscus & 130.7 & 228.2 & 0.57 & 33.8 & 133.2 & 43.4 & 17.9 & 1.53 & 49.9 & 65.38 \\
\hline Pistacia terebinthus & 85.5 & 115.2 & 0.74 & 24 & 59.1 & 14.2 & 17.2 & 1.85 & 48.7 & 49.26 \\
\hline Populus alba & 109.9 & 170.3 & 0.65 & 25.1 & 120 & 3.2 & 20.7 & 2.59 & 51.8 & 80.53 \\
\hline Pyrus bourgaeana & 86.3 & 152 & 0.57 & 29.5 & 85.9 & 15.8 & 20.8 & 2.75 & 49.8 & 50.83 \\
\hline Quercus coccifera & 121.1 & 229.1 & 0.53 & 26 & 126.5 & 32 & 43.9 & 1.7 & 50 & 65.38 \\
\hline Quercus faginea & 99.1 & 148.4 & 0.67 & 23 & 78.6 & 15.5 & 30.4 & 2.87 & 47 & 65.38 \\
\hline Quercus ilex spp.ballota & 187.8 & 227.8 & 0.82 & 24.9 & 117.5 & 21 & 63.5 & 1.99 & 50.6 & 65.38 \\
\hline Rhamnus lycioides & 45 & 128.3 & 0.35 & 27.2 & 84.4 & 9.8 & 6.9 & 3.29 & 47.3 & 81.19 \\
\hline Rosa canina & 69.6 & 141.4 & 0.49 & 35.1 & 74.1 & 10.7 & 21.6 & 2.19 & 45.6 & 50.83 \\
\hline Rosmarinus officinalis & 72.6 & 142.6 & 0.51 & 20.2 & 66.9 & 9.2 & 46.4 & 1.28 & 53.9 & 30.65 \\
\hline Rubus ulmifolius & 72.4 & 125 & 0.58 & 23.6 & 69.3 & 8.8 & 22.3 & 2.11 & 47.8 & 50.83 \\
\hline Salix atrocinerea & 81.3 & 149.3 & 0.54 & 29 & 83.6 & 11.4 & 25.4 & 2.12 & 50.3 & 80.53 \\
\hline Smilax aspera & 68.1 & 171.6 & 0.4 & 30.8 & 112.6 & 17.9 & 8.7 & 2.72 & 47.2 & 49.26 \\
\hline Teucrium fruticans & 81.5 & 145.3 & 0.56 & 29 & 81.1 & 9.3 & 25.9 & 1.69 & 48.2 & 30.65 \\
\hline Ulmus minor & 28.6 & 121.8 & 0.23 & 39 & 52.5 & 17.6 & 12.7 & 2.86 & 42 & 93.63 \\
\hline Vitis vinifera & 30.7 & 112.9 & 0.27 & 23.2 & 62.7 & 13.9 & 11.7 & 2.6 & 48.4 & 81.19 \\
\hline
\end{tabular}




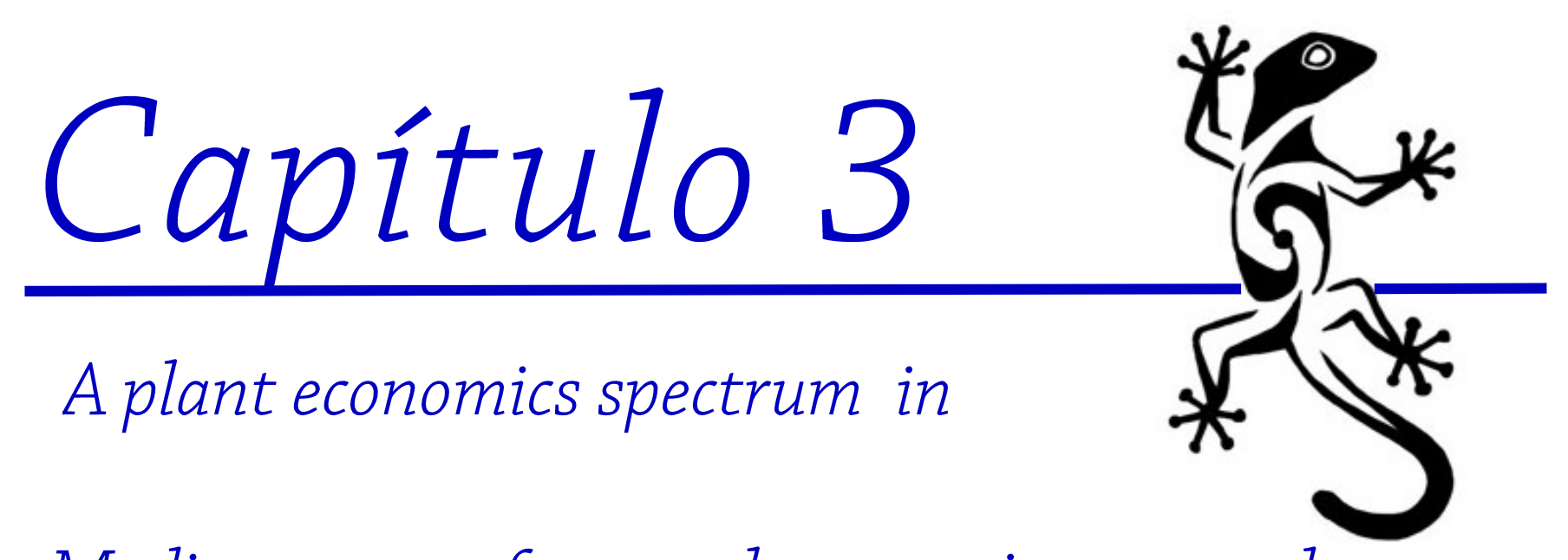

Mediterranean forests along environmental

gradients: is there cooriation among leaf, stem

and root traits?

"Aprender siempre del munda natural. que

optimiza al máxima los recursos, que na produce residuas, que se adapta y evoluciona"

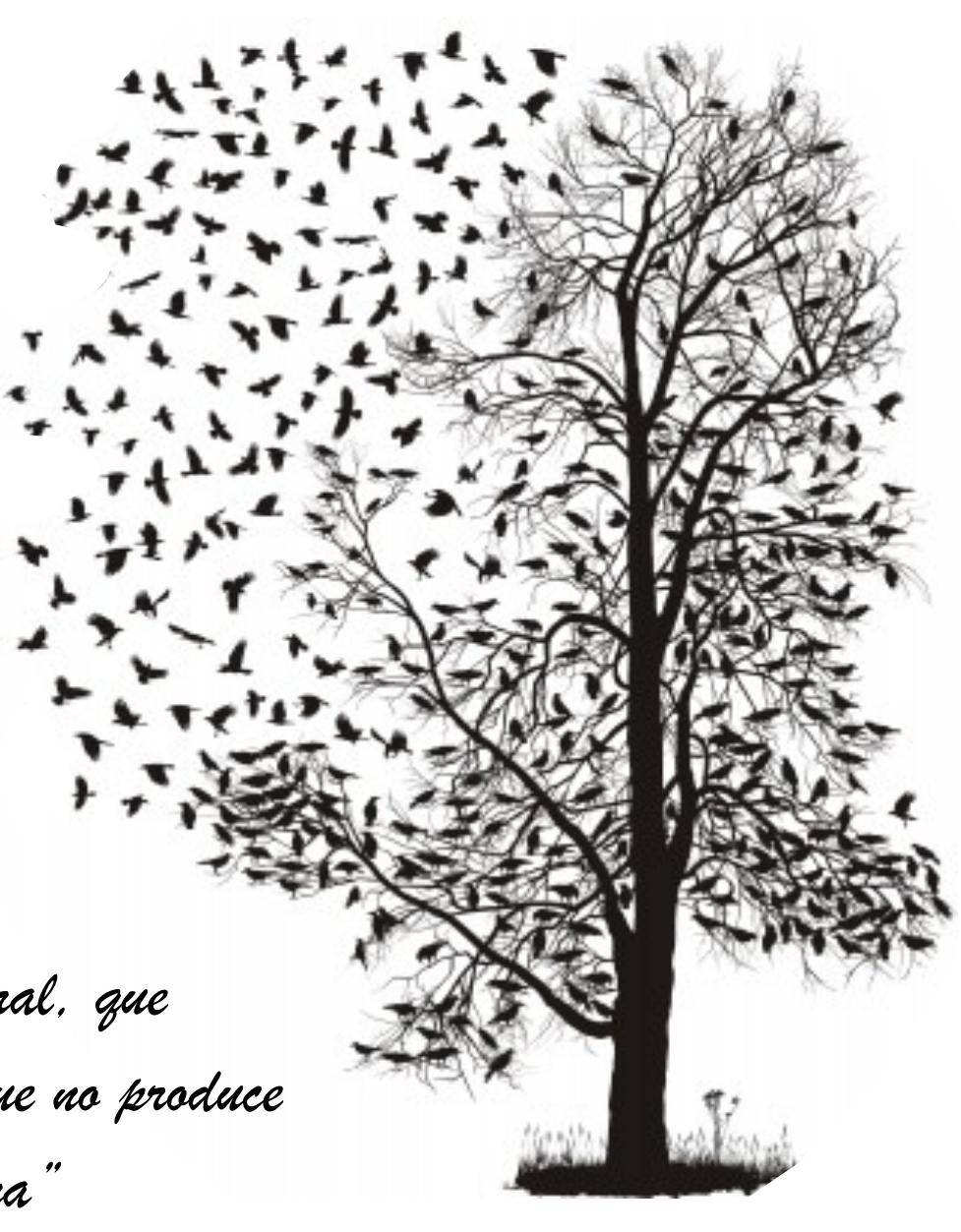





\section{A plant economics spectrum in Mediterranean forests along environmental gradients: is there coordination among leaf, stem and root traits?}

Enrique G. de la Riva, Ambra Tosto, Ignacio M. Pérez-Ramos, Carmen M. Navarro-Fernández, Manuel Olmo, Niels P.R. Anten, Teodoro Marañón \& Rafael Villar

\author{
Keywords \\ Acquisition-conservation trade-off; Functional \\ trait; LHS scheme; Phylogenetically \\ independent contrasts; Root dry matter \\ content; Seed mass; Specific leaf area; \\ Tolerance-fecundity model \\ Nomenclature \\ Castroviejo (1986-2012) \\ Received 9 May 2014 \\ Accepted 31 July 2015 \\ Co-ordinating Editor: Francesco de Bello
}

de la Riva, E.G. (corresponding author, enga70@gmail.com) ${ }^{1}$,

Tosto, A. (elektron1987@yahoo.it) ${ }^{1}$, Pérez-Ramos, I.M. (imperez@irnase.csic.es)², Navarro-Fernández, C.M.

(nfcarmen@hotmail.com) ${ }^{2}$,

Olmo, M. (b12olprm@uco.es) ${ }^{1}$,

Anten, N.P.R. (niels.anten@wur.nl) ${ }^{3}$,

Marañón, T. (teodoro@irnase.csic.es)²,

Villar, R. (rafael.villar@uco.es) ${ }^{1}$

${ }^{1}$ Área de Ecología, Facultad de Ciencias, Universidad de Córdoba, 14071 Córdoba, Spain;

${ }^{2}$ Instituto de Recursos Naturales y Agrobiología de Sevilla, IRNAS, CSIC, 41012

Seville, Spain;

${ }^{3}$ Centre for Crop Systems Analysis,

Wageningen University, P.O. Box 4706700 AK, Wageningen, The Netherlands

\begin{abstract}
Questions: Is there any evidence of coordination among leaf, stem and root traits, and thereby of the existence of a plant economics spectrum at the species and community level in Mediterranean forests? Are these traits related to plant size and seed mass?
\end{abstract}

Location: Mediterranean forests and shrublands, Sierra Morena mountains, Córdoba, southern Spain.

Methods: We selected nine woody plant communities along a natural local gradient of soil water and nutrient availability. We measured key leaf, stem, root and whole-plant traits for 38 dominant woody plant species. The variation across species of 15 functional traits (of the leaf, stem and root) was analysed and coordination among them was tested. We explored the relationships between these traits (hereafter 'resource-use traits' due to their close association with the acquisition-conservation trade-off) and plant height and seed mass. Finally, we compared results at species level with those calculated at community level, considering community-weighted means (CWMs).

Results: We found a significant coordination between traits belonging to different plant organs, and propose the existence of a plant economics spectrum in Mediterranean forests along the environmental gradient. However, weaker relationships were found within groups of species under similar environmental conditions. We did not find the expected orthogonal relationships between plant height, seed mass and resource-use traits. Relationships among functional traits were stronger at the community level than at the species level.

Conclusions: This study reveals a high degree of functional coordination between traits belonging to different plant organs at both species and community level, and suggests the existence of a plant economics spectrum across 38 Mediterranean woody plant species. However, this general trend of functional coordination between organs became weaker or disappeared when considering restricted groups of species belonging to environmentally similar sites (e.g. dry vs wet sites), suggesting that the diversification of strategies within communities is not related to the economics spectrum at a lower spatial scale. Interestingly, the high degree of coordination between resource-use traits and seed mass at the community level seems to support the tolerance-fecundity model, which predicts an inverse relationship between fecundity and stress tolerance.

\section{Introduction}

Functional plant traits are commonly used indicators of species ecological functions, as they allow us to veıеr understand plant strategies and distribution (Violle et al. 2007; Reich 2014). Thus, the functional trait approach has been used as a tool to comprehend the spectrum of functional strategies in plants and their 
relationships with the environment (Garnier \& Navas 2012 and references therein). The trade-off between acquisition and conservation of resources is a good example of different functional strategies in plants, which can be described by the range of trait variation that defines the broadly understood leaf economics spectrum (Díaz et al. 2004; Wright et al. 2004). This spectrum runs from species with a conservative resource-use strategy (i.e. sclerophyllous, long-lived leaves and low photosynthetic rates), to those with contrasting traits commonly associated with rapid resource capture and a high relative growth rate (Reich et al. 1998a; Wright \& Westoby 2001; Villar et al. 2006; Poorter \& Garnier 2007). However, the extent to which this paradigm can be extended to other organs, e.g. roots and stems, and to the level of the whole plant still remains unclear (Freschet et al. 2010; Prieto et al. 2015). Thus, there is controversy about how the traits of different plant organs (i.e. leaf, stem and root) co-vary across species and the extent to which this co-variation adheres to a plant economics spectrum (Freschet et al. 2010; Laughlin et al. 2010).

Some recent studies have reported that the trade-off between acquisition and conservation of resources can be also extrapolated to the below-ground component (Birouste et al. 2012; Prieto et al. 2015), providing support for the hypothesis that the paradigm of the leaf economics spectrum can be extended to the whole-plant level (Freschet et al. 2010). Recently, Pérez-Ramos et al. (2012) found evidence in Mediterranean grasslands that plant economics could be scaled up at the community level, with potential repercussions for relevant ecosystem processes and services (e.g. Freschet et al. 2013). In these studies, leaf traits indicative of an acquisitive strategy were associated with similar acquisitive root traits, indicating that different organs converge in position along the economics spectrum. However, studies on woody plants from tropical forests did not find positive correlations between leaf and root traits (Fortunel et al. 2012) or between leaf and stem traits (Baraloto et al. 2010). These authors suggested that functional trade-offs in different tissues operate independently between components, as a result of optimization of the survival and growth strategies in more highly competitive environments, e.g. tropical forests. The relationships among traits belonging to different organs may also change if they are affected by different environmental conditions (Cordlandwehr et al. 2013) or because different floras are subject to different evolutionary constraints (Heberling \& Fridley 2012). Therefore, we need more studies that test the coordination among leaf, stem and root traits in different environments and at different spatial scales to reach generalizations on the existence and nature of a plant economics spectrum at both the species and community level.
The leading dimensions of ecological variation among plants include not only functional traits associated with the use of resources (resource-use traits) but also those associated with competition for light (e.g. plant height) and reproductive ability (e.g. seed number and size; Westoby \& Wright 2006; Reich 2014). Among different models, the tolerance-fecundity model (Muller-Landau 2010) assumes an inverse relationship between fecundity and stress tolerance across species. The 'leaf--height-seed' scheme (LHS) proposed by Westoby (1998), and expanded to the root dimension by Laughlin et al. (2010), assumes that leaf economics is essentially independent of the dimensions of plant height and seed production (Liancourt et al. 2009; Laughlin 2014). However, more studies are necessary to discern whether these two models (tolerancefecundity and LHS) can be generalized to other biomes and ecosystem types.

In this study, we explored the spectrum of variation in functional traits and the degree of coordination between leaf, stem and root traits for the first time in Mediterranean woody plant species growing in natural conditions. The principal aim was to test the existence of a whole-plant economics spectrum in forests and shrublands of southern Spain. We also explored two additional functional dimensions: plant height and reproductive ability (particularly seed mass). The observed relationships among functional traits across plant species were then tested at the community level, using community-weighted means (CWMs; sensu Garnier et al. 2004), to prove their consistency at both organizational levels. The results obtained must be considered in a determined environmental and evolutionary context. In this case study, the environmental and evolutionary context is a species pool of 38 woody plant species sampled in nine different plant communities (including forests and shrublands) that were distributed along a local environmental gradient. We selected a wide gradient of soil water availability with the aim of spanning a large range of potentially different resource-use strategies. We expected to find that:

1. The functional traits of a set of co-occurring plant species co-vary according to a main specialization axis that reflects a wide range of resource-use strategies (Díaz et al. 2004; Wright et al. 2004). Under Mediterranean conditions, where plants survival and growth are commonly limited by the scarcity of soil water and nutrients, we expect to find strong positive coordination between leaf, stem and root traits, reflecting a wholeplant economics spectrum across the resource-use gradient (Freschet et al. 2010; Pérez-Ramos et al. 2012).

2. This general coordination of functional traits among organs may change with the spatial scale (Funk \& Cornwell 2013); for instance when considering 
separately sets of species inhabiting sites at different positions on the environmental gradient. Thus, we expect to find weaker coordination of functional traits among organs when considering a restricted range of the environmental gradient (e.g. dry vs wet sites) than when analysing at a higher spatial scale (i.e. considering the whole gradient heterogeneity).

3. The three main functional dimensions, resource-use traits (associated with the acquisition-conservation trade-off), plant height (related to competition for light) and seed mass (related to germination, establishment and dispersal), are orthogonal, according to the LHS hypothesis (Westoby 1998; Laughlin et al. 2010).

4. Based on previous findings indicating that dominant species tend to have trait values that are better linked to their environments than those of rare species (Ackerly et al. 2002; Cingolani et al. 2007; Domínguez et al. 2012), the relationships among functional traits are stronger at the community level (using CWMs) than at the species level.

We tested these expectations for a set of Mediterranean forest and shrubland communities along an environmental gradient in southern Spain.

\section{Methods}

\section{Study area}

The study was conducted in Mediterranean forests and shrublands located in the Sierra Morena mountains in southern Spain (Córdoba). The area is characterized by a continental-Mediterranean climate, with cold wet winters and dry warm summers. The mean annual temperature is $17.6{ }^{\circ} \mathrm{C}$ and mean annual precipitation is $536 \mathrm{~mm}$ (data from the Spanish Meteorological Agency, AEMET, 19712000, http://www.aemet.es/es/serviciosclimaticos/datos climatologicos). Several shrub and arborescent species, such as Cistus albidus and Quercus coccifera, are abundant in drier soils, while broad-leaf deciduous trees, such as Alnus glutinosa or Fraxinus angustifolia, are dominant in moister soils (see Appendix S1 for details of the 38 studied species).

\section{Sampling design}

Nine sampling sites were selected along a natural and wide gradient of soil resource availability (mainly soil water; de la Riva et al. 2015). In spring 2012, four 20-m long transects were set up randomly in each of the nine sampling sites, with a minimum distance of $10 \mathrm{~m}$ relative to one another. The species abundance and composition were measured, as well as the cover of each woody species intercepted by each of the four 20 -m transects. The mean relative abundance for each species and site was calculated as the mean value of the four transects. For trait measure- ments (see details below), we ranked the species by their relative abundance and selected those representing at least $90 \%$ of the total plant woody cover measured in each site. These species comprise most of the biomass in that community and are expected to have a major role in the functioning of the ecosystem (Lavorel et al. 2008). This gave a total of 38 selected species, many of them appearing in more than one sampling site (Appendix S1).

\section{Plant measurements}

In late spring 2012, during the peak of plant growth, healthy adults of the most dominant woody plant species were selected randomly. We measured 15 key functional traits related to morphology (in the leaf, stem and root), physiology, plant size and reproduction (see the traits and functional roles in Appendix S2), covering the main functional dimensions. All these trait measurements were carried out according to the criteria defined in PérezHarguindeguy et al. (2013).

\section{Leaf morphological traits}

Six individuals per species and sampling site were chosen, on which the following leaf traits were measured: specific leaf area (SLA, leaf area per unit dry leaf mass), leaf dry matter content (LDMC, dry mass per unit water-saturated fresh mass) and leaf thickness (LThick). Leaf density (LD) was calculated as the inverse of SLA divided by LThick (Witkowski \& Lamont 1991).

\section{Stem morphological traits}

On the same six individuals per species and sampling site, we measured the following stem traits. Stem dry matter content (SDMC) was obtained as the ratio of dry to saturated fresh mass. Stem wood density (WD) was calculated as the dry mass divided by the stem fresh volume (based on the Archimedes principle, measuring the volume of water displaced by immersion of the stem).

\section{Root morphological traits}

Roots were sampled at the individual level by excavating the first $20-30 \mathrm{~cm}$ of the soil depth near the plant basal stem, for four individuals per species and sampling site. We selected this specific soil depth based on a previous study with Mediterranean woody vegetation, which demonstrated that the majority of fine roots appear in the first $27 \mathrm{~cm}$ of soil depth (Silva \& Rego 2004). These root samples were used to measure four key below-ground traits in fine roots ( $<2 \mathrm{~mm}$ diameter): specific root area (SRA, root area per unit root dry mass), root dry matter content (RDMC, 
root dry mass per unit water-saturated fresh mass), root diameter (Rdi, average diameter of fine roots) and root tissue density (RD, root dry mass per root volume). The root area, diameter and volume data were obtained by analysing the scanned root samples with WinRHIZO 2009 (Regent Instruments, Quebec City, QC, CA). The RD was calculated as root dry mass divided by root volume.

\section{Physiology-related traits}

Three functional traits related to plant physiology were considered: leaf nitrogen concentration (LN), leaf chlorophyll (LChl, concentration of chlorophyll per unit fresh leaf mass) and leaf carbon isotope ratio $\left(\delta^{13} \mathrm{C}\right)$. Both $\mathrm{LN}$ and LChl are closely correlated with the mass-based maximum photosynthetic rate (Evans \& Poorter 2001; PérezHarguindeguy et al. 2013). The $\delta^{13} \mathrm{C}$ reflects a trade-off between photosynthesis and stomatal conductance (Seibt et al. 2008) and provides a time-integrated measure of the intrinsic water-use efficiency (Farquhar et al. 1982). LN and LChl were measured in leaves of six individuals per species and sampling site, whereas $\delta^{13} \mathrm{C}$ was determined in a mixture of leaves from six different individuals per species and sampling site.

\section{Plant size trait}

Plant height (Phg) was measured as a functional trait commonly used to quantify plant size. Measurements were made with a metric tape on ten individuals per species and sampling site. In tall species, such as trees, plant height was estimated using the 'Christen height' meter, based on trigonometric principles (Klein 2007).

\section{Seed trait}

Seed mass data were compiled from the published literature (García-Fayos 2001) and from seed databases (Semillas Cantueso, http://www.semillascantueso.com/es/, Jardín Botánico de Córdoba and IEED, Goethe-University Frankfurt, http://www.seed-dispersal.info). Although it would have been preferable to obtain seed data of the 38 species by direct collection, we rely on these data as representative of this functional trait for reproduction.

\section{Data analyses}

A general principal components analysis (PCA) was performed with the whole set of functional traits (15 traits) for the 38 woody plant species (average value for each species) to obtain an overview of the multidimensional spectrum of variation. Then we performed a PCA for each organ (leaf, stem and root) separately (similarly to
Freschet et al. 2010) using trait values at the species level.

The degree of coordination among traits belonging to different plant organs (leaf, stem and root) was determined with standardized major axis (SMA) regressions, using the first PCA axis of each organ. SMA is a statistical tool highly recommended for allometric studies (Warton et al. 2006) when there is no clear dependent or independent variable and there is an interest in knowing the slope between the two axes. The relationships between morphological traits (in leaf, stem and root) and physiology-related traits, plant size and seed mass were also explored by SMA fitting.

In order to control for the influence of species evolutionary history at the species level, all the above-described relationships were also determined by fitting a phylogenetic generalized least squares model. By calculating phylogenetically independent contrasts (PIC), we can assess the impact of phylogeny on our results (Webb et al. 2008; Verdú \& Pausas 2013). For these PICs, we used the pgls function of the caper package for R (R Foundation for Statistical Computing, Vienna, AT), which addresses phylogenetic non-independence among species by incorporating covariance between taxa into calculation of the estimated coefficients. The phylogenetic relationships between species (see Appendix S3) were obtained with the Phylomatic program, implemented in Phylocom 4.2, and the reference phylogeny contained in R20120829.new (Webb et al. 2008). We resolved the topology of the tree (below family level) with information from published phylogenies (Manos et al. 1999; Fernández-Mazuecos \& Vargas 2010; Verdú $\delta$ Pausas 2013). Age estimates for nodes in the tree were taken from Verdú \& Pausas (2013), and branch lengths were adjusted using the BLADJ algorithm in Phylocom 4.2.

To assess if coordination of functional traits between organs (leaf, stem and root) is also consistent within environments located at different positions on the gradient, we first grouped species and sampling sites using non-metric multidimensional scaling analysis (NMDS) with the function 'metaMDS' in vegan. Then, for each of these groups of species representing major community types, we tested the relationships between organs using SMA regressions.

For analyses at community level, the traits were weighted by the relative abundance of their constitutive species (using the species trait value for each plot) to calculate CWMs in each of the nine woody communities, according to Garnier et al. (2004). In order to obtain comparative results with respect to the species analysis, we also explored relationships between morphological traits of different plant organs (leaf, stem and root) at the community level, and performed a PCA for each organ separately. The degree of coordination among traits belonging to different plant organs (leaf, stem and root) was deter- 
mined through SMA regressions, using the first PCA axis of each organ.

All these analyses were conducted in the R 2.10.0 statistical platform using the packages 'ape' (Paradis et al. 2004), 'car', 'FactoMiner' (Lê et al. 2008), 'phytools' (Revell 2012), 'smatr' (Warton et al. 2012) and 'vegan' (Dixon 2003).

\section{Results}

The results of the general PCA for the 15 functional traits and 38 woody species are shown in Fig. 1. The first PCA axis accounted for $44 \%$ of overall variation and was related in one extreme (negative values) with high values of traits (SLA, SRA, LChl and LN) that were positively correlated among themselves (Appendix S4) and representative of the resource acquisition strategy. At the opposite extreme (positive values) were species with high values of traits (LDMC, LTh, SDMC, RDMC and $\delta^{13}$ ) that were also positively correlated among themselves (Appendix S4) and indicative of the resource conservation strategy. The second principal component, which explained $15 \%$ of the overall variance, was represented mainly by variations in leaf density, seed mass and plant height. Similarly to the whole-plant PCA, the three organ PCAs showed high scores for their respective first principal components $(61 \%$, $94 \%$ and $65 \%$ of overall variation explained for leaf, stem and root, respectively).

The SMA regressions among the set of morphological traits for different organs (leaf, stem and root; using the first PCA axis for each organ) provided significant and positive regression coefficients and their slopes did not significantly differ from 1 (Fig. 2, species analyses), indicating strong coordination and isometry among these organs.

In addition, the morphological traits (in leaf, stem and root) were significantly correlated with the physiologyrelated traits, such as leaf $\mathrm{N}$ (Fig. 3 ), $\delta^{13} \mathrm{C}$ and chlorophyll (with the exception of stem morphology and LChl; Appendix S5). Plant size was negatively related to root morphology and leaf morphology (Fig. 3). Regarding links between vegetative and reproductive traits, we did not find any significant relationships between morphological traits and seed mass (Fig. 3). Only leaf morphology showed a positive correlation with seed mass, although this relationship was phylogenetically dependent (Appendix S6).

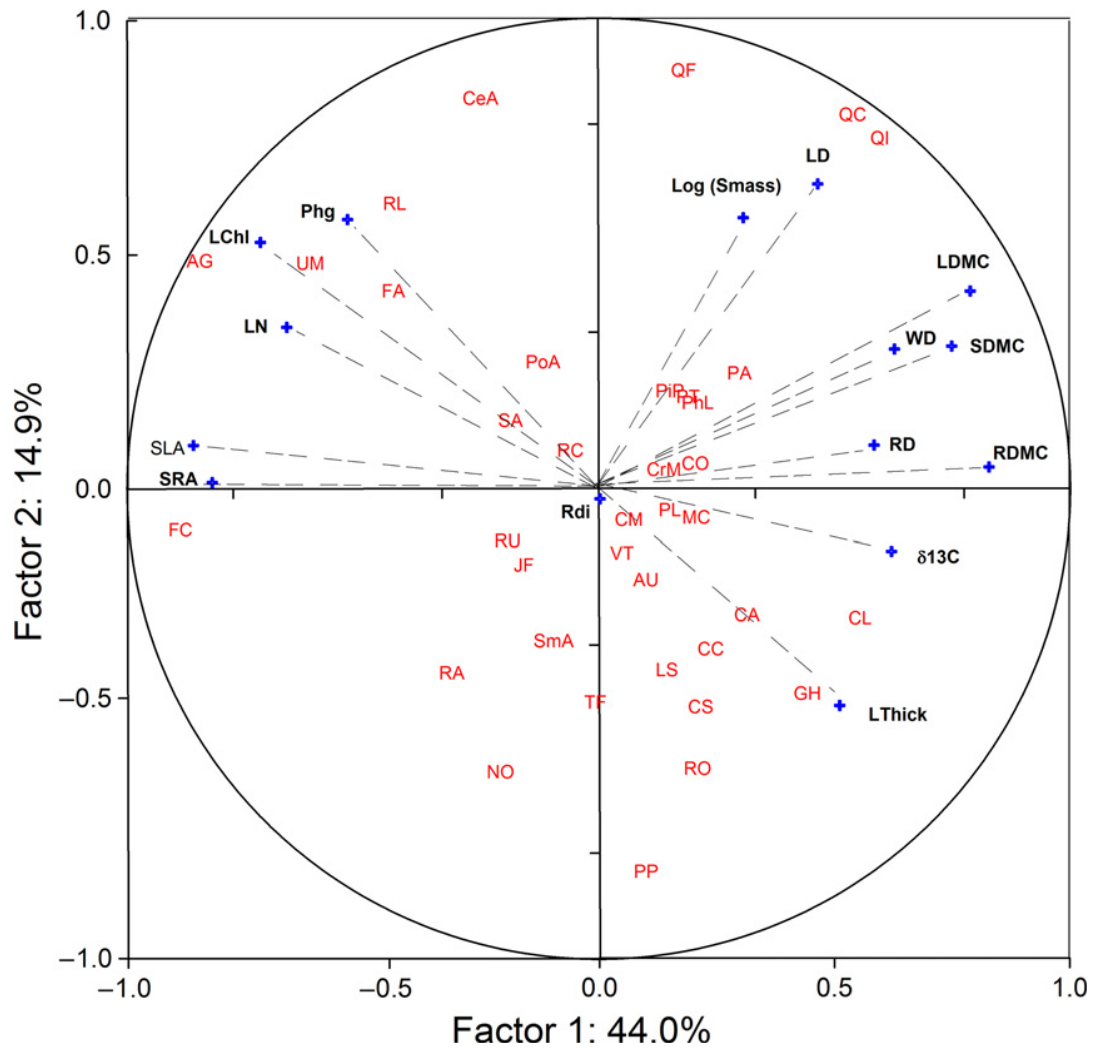

Fig. 1. Principal components analysis (PCA) showing the plant economics spectrum, from conservative (right) to fast-growing or acquisitive (left) species. Variables (plant traits) used for the PCA are displayed with their vector. The plant economics spectrum is represented as a straight horizontal line (axis 1). See Appendix 1 and 2 for abbreviations of traits and species. 


\section{SPECIES}

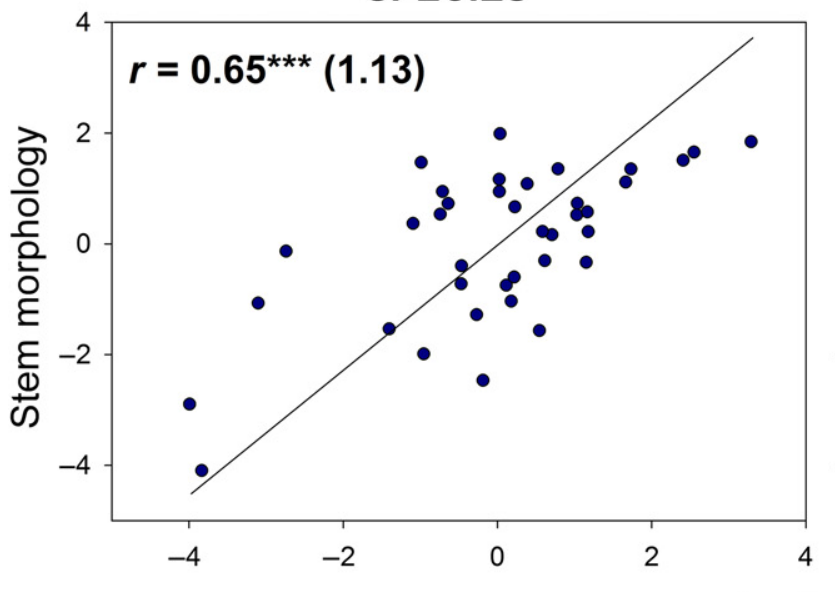

COMMUNITIES

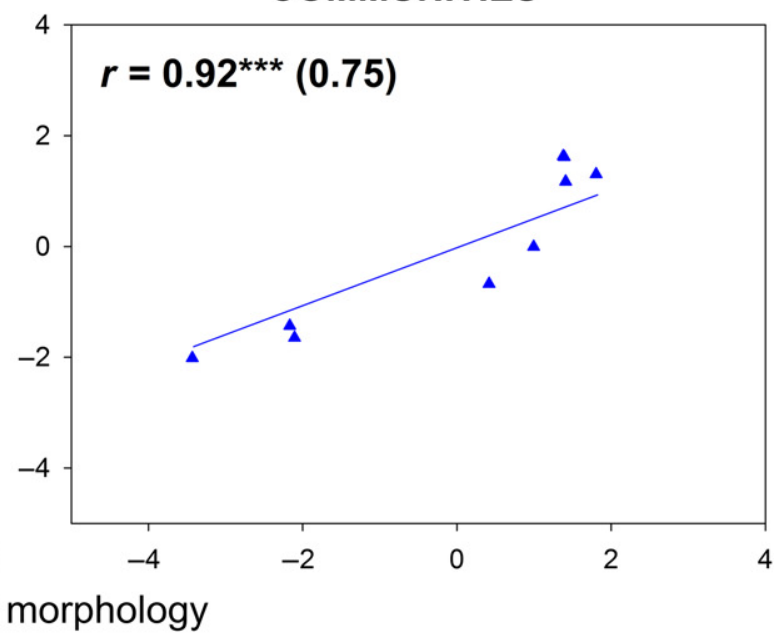

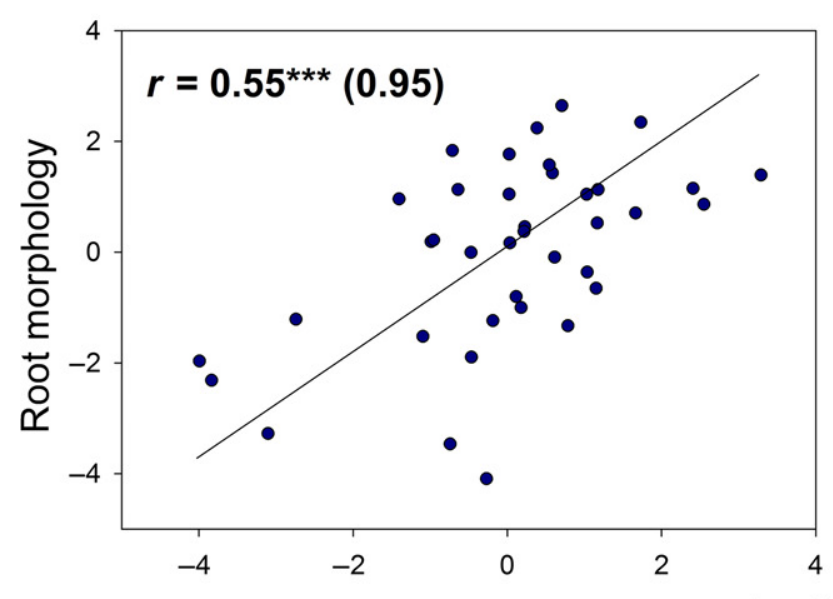
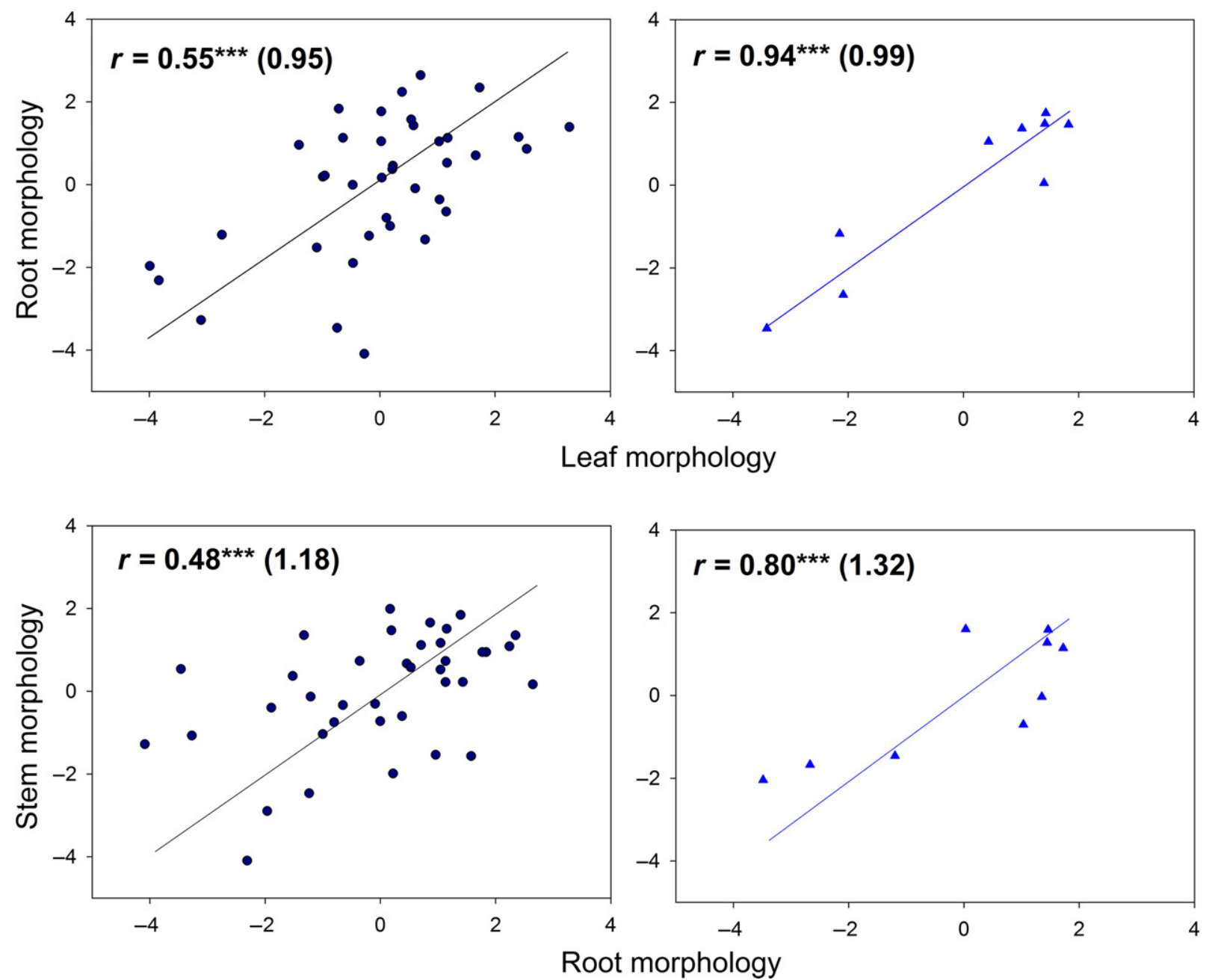

Fig. 2. Standardized major axis (SMA) regressions between morphological traits belonging to different plant organs (leaf, stem and root) at the species (dark circles) and community (light blue triangles) levels. For these analyses we used the first PCA axis of the different morphological traits belonging to different plant organs (leaf, stem and root). The Pearson correlation coefficient $(r)$ is given, and the level of significance is $* * * P<0.001$. The slopes of the regressions are indicated within brackets and are not statistically different from $1(P>0.05)$. 


\section{SPECIES}
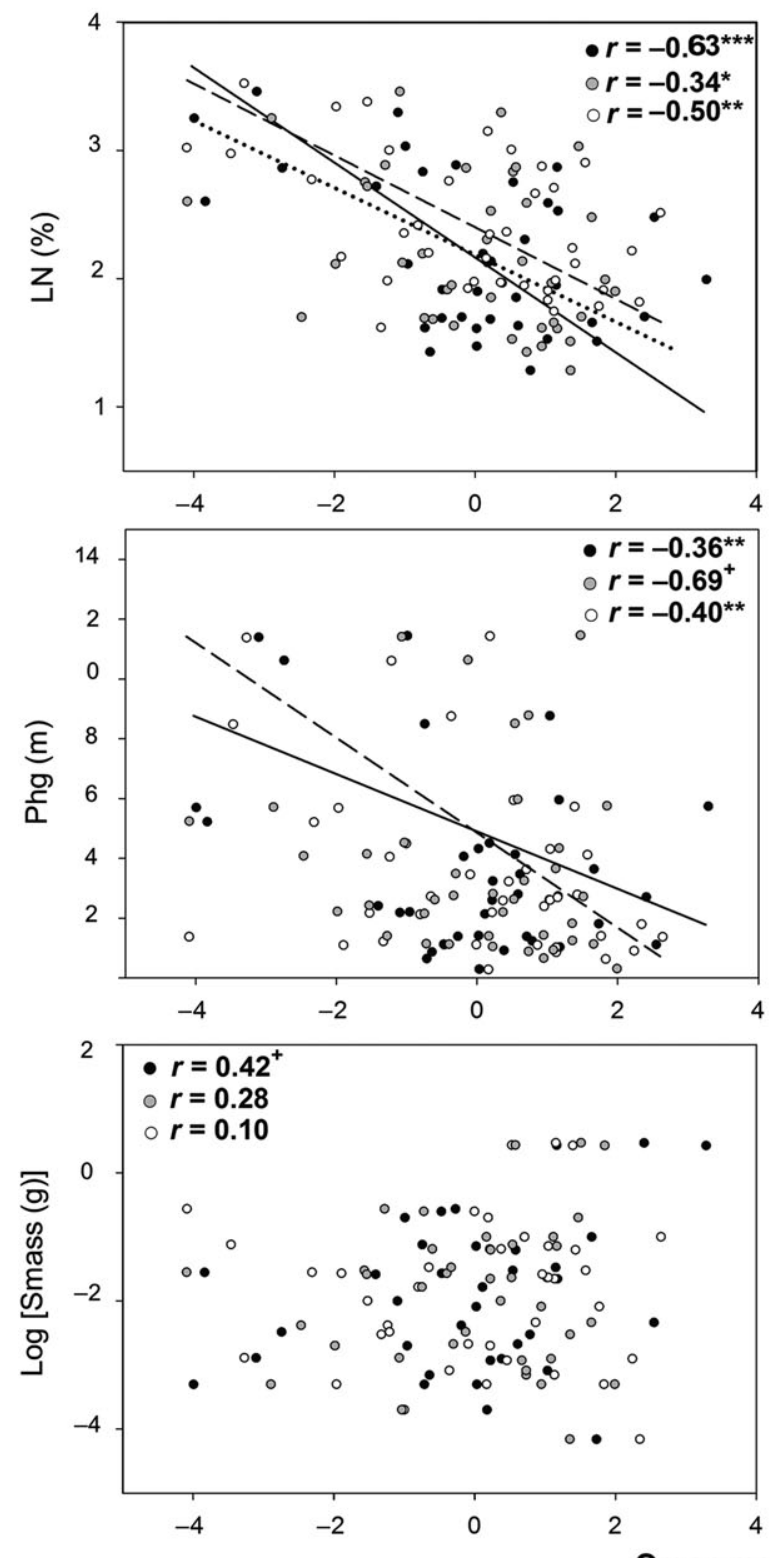

Acquisitive

\section{COMMUNITIES}
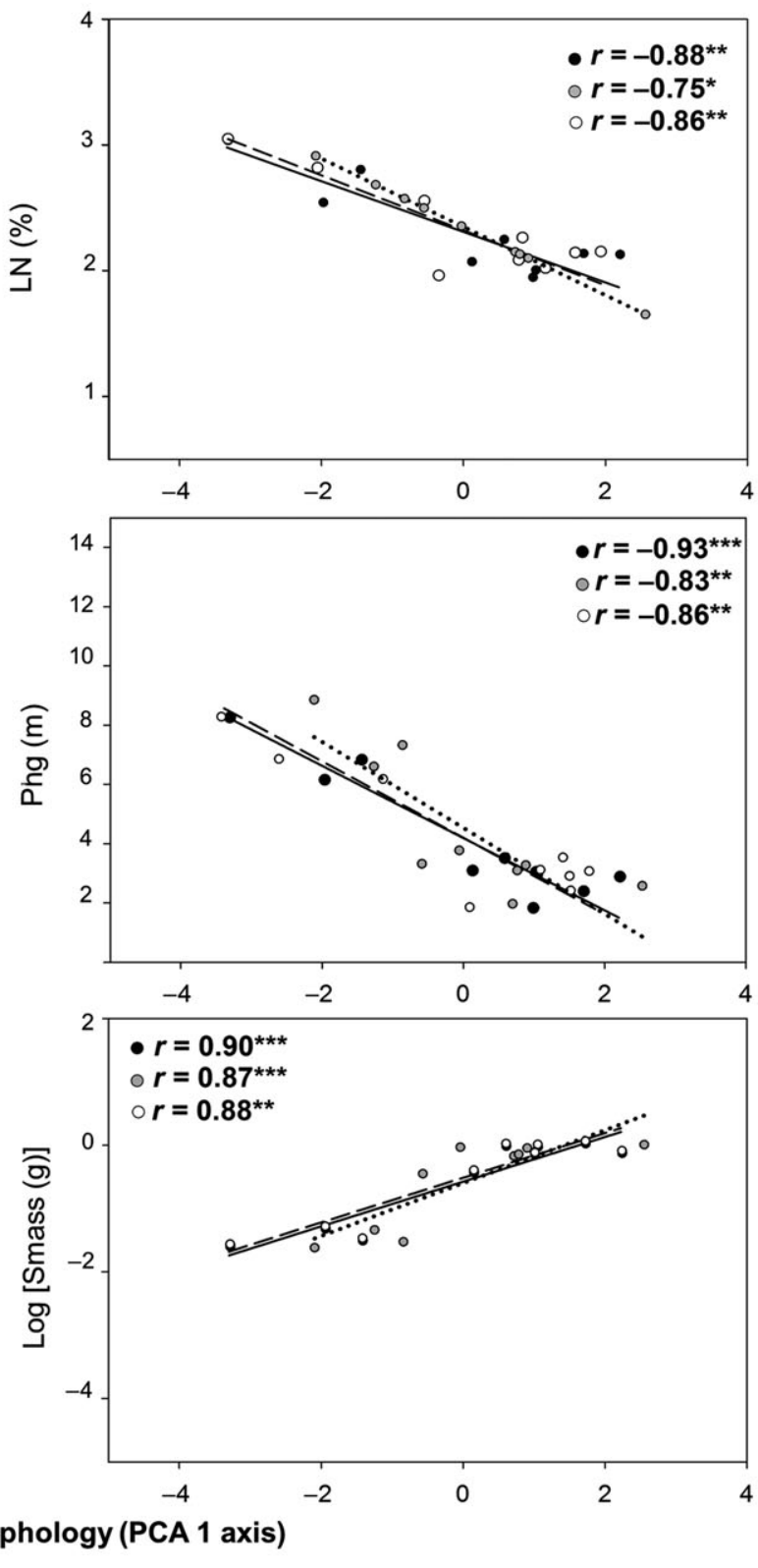

\section{Conservative}

Fig. 3. Standardized major axis (SMA) regressions between morphological traits (leaf, black circles and solid lines; stem, grey circles and dotted lines; root, white circles and dashed lines) ordered along an acquisitive-conservative gradient (as PCA first axis values) and leaf nitrogen (LN), plant height (Phg) and seed mass (Smass) at the species (left column) and community (right column) levels. The Pearson correlation coefficient ( $r$ ) is given and SMA regression line is plotted when significant. $* P<0.05, * * P<0.01,{ }^{* * *} P<0.001 ;{ }^{+}$indicates that significant correlations were not consistent with phylogenetic contrast.

All the significant relationships observed at species level were consistent after considering phylogenetically independent contrasts (PIC; Appendix S6), except where noted above.
Next, we analysed the consistency of the coordination of functional traits between organs under different environmental conditions. First, three major groups of species representing the main community types were defined with 
NMDS (Appendix S7). The Wet group ( -0.6 to -0.2 on first NMDS axis) was formed mainly of deciduous species from wetter sites; the Medium group (-0.2 to 0.2) had species with intermediate characteristics; and the Dry group (0.2 to 0.6 ) had mainly sclerophyllous species from drier sites. Second, we performed SMA regression of functional traits separately for each of these three groups of species and found weaker coordination at this level. Significant, positive SMA regressions were found only among leaf and stem morphology for species from Wet and Medium sites, and their slopes did not differ significantly from 1 (Fig. 4).

At the community level, the trends obtained for the coordination among morphological traits of leaf, stem and root were very similar to those found at the species level; interestingly, the correlation coefficients were higher than at the species level (Fig. 2). The most striking difference was that morphology of the leaf, root and stem was closely related to plant height and seed mass at the community level, despite not being correlated across species (Fig. 3).

\section{Discussion}

Evidence for a plant economics spectrum in Mediterranean environments

Our results, based on 38 Mediterranean woody plant species, clearly show that morphological traits for different plant organs are highly coordinated (Fig. 2). In addition, slopes of the SMA regressions between traits representative of leaf, stem and root morphology did not differ from 1 , indicating synchronization of the structures of these organs. This suggests that these morphological traits have evolved in a correlated way as part of a whole-plant resource uptake strategy, and these relationships are not affected when phylogenetic relatedness is considered.

Understanding the strategic dimensions of trait variation along environmental gradients is a recent important goal of functional ecology (Freschet et al. 2010). In this respect, our results from a local Mediterranean gradient support

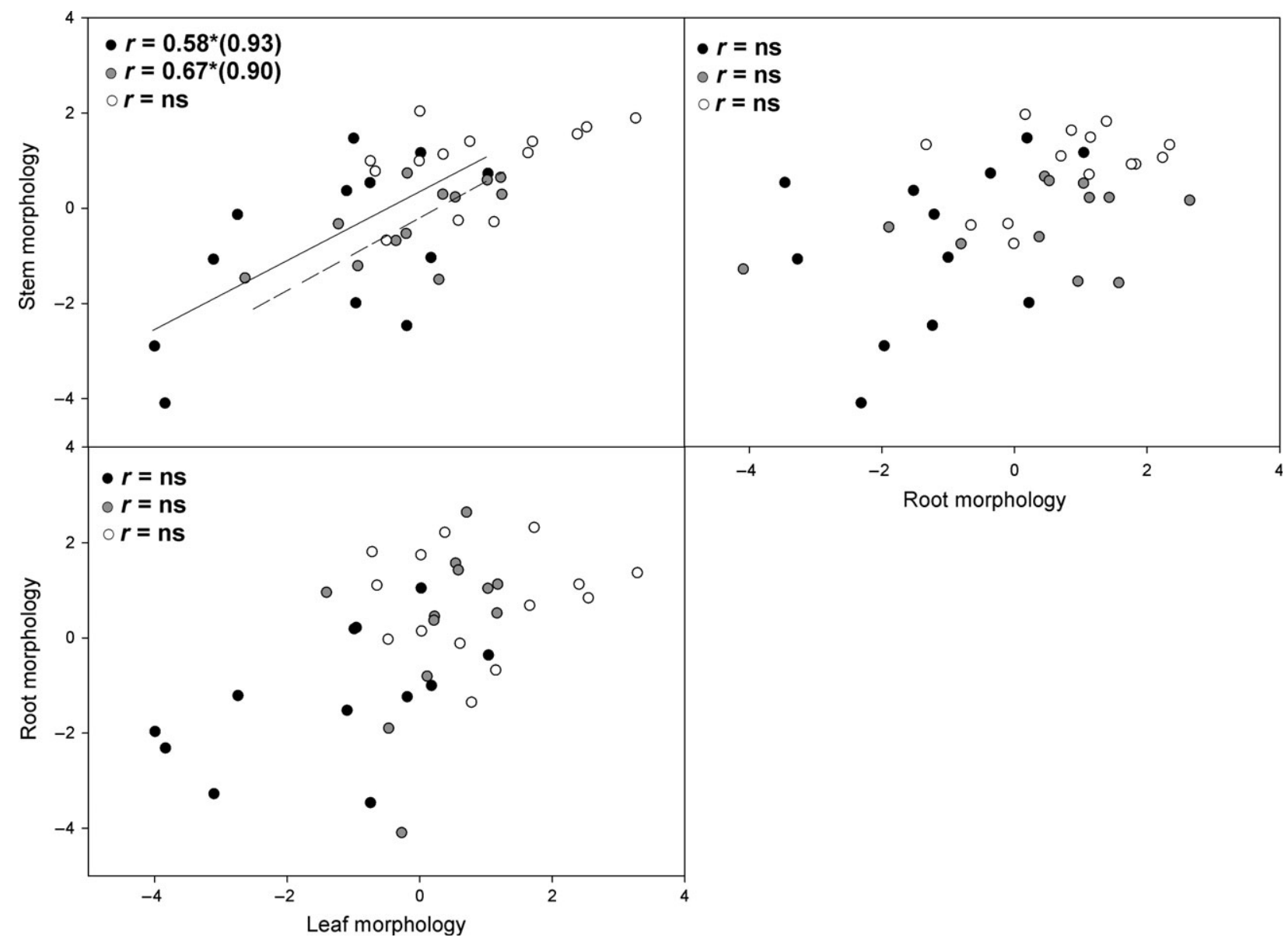

Fig. 4. Standardized major axis (SMA) regression between morphological traits for species from three different environments: Wet (black circles and solid lines), Medium (grey circles and dashed lines) and Dry (white circles). The Pearson correlation coefficient ( $r$ ) is given and the significance level is $* P<0.05$. The three groups of species were classified with non metric multidimensional scaling analysis (NMDS) (Appendix S7). 
some previous studies on woody and herbaceous plant species (Reich et al. 1998b; Freschet et al. 2010), but contrast with other results obtained for leaf and root traits along environmental gradients in tropical woody plants (Fortunel et al. 2012) and savanna-like grassland species (Tjoelker et al. 2005). These contradictory results suggest that the coordination between leaf, stem and root traits is not a universal trend, with large differences depending on the specific constraints of each ecosystem (Kembel \& Cahill 2011 ). For example, recent studies suggested that Amazonian trees optimize their survival and growth by investing differentially in leaves with respect to stem or root tissues (Baraloto et al. 2010; Fortunel et al. 2012), probably as a result of a trade-off between abiotic constraints and strong competition. We suggest that coordination at the wholeplant level (leaf, stem and root) found in environments having more adverse environmental conditions, such as sub-arctic (Freschet et al. 2010), arid (Liu et al. 2010) or semi-arid Mediterranean ecosystems (this study), could be explained through the abiotic limitations of these sites, which may promote the convergence of functional traits in different organs.

In addition, plant species with short-lived and low-density tissues (i.e. with higher values of SLA and SRA) had higher LN and LChl values (i.e. potentially higher growth rates). In contrast, species with long-lived tissues commonly associated with a more conservative use of resources (i.e. high-density leaf, stem and root tissues) had higher values of $\delta^{13} \mathrm{C}$ (typical of water-use efficient species; Reich 2014; de la Riva et al. 2014). The construction of plant tissues of woody Mediterranean species implies a trade-off between mechanical support, water conductance and storage of water and assimilates (Pratt et al. 2007). These results support our initial hypothesis that the traits of leaves, stems and roots involved in the resource acquisition-conservation trade-off tend to co-vary, and demonstrate the existence of a whole-plant economics spectrum in Mediterranean forests and shrublands of southern Spain (see other examples in Freschet et al. 2010; MéndezAlonzo et al. 2012).

However, the general trend of coordination between traits of different organs became weaker or disappeared at a lower spatial scale, when considering groups of species belonging to environmentally similar sites (Fig. 4). Thus, we only found isometric relationships (slopes close to 1) between leaf and stem morphology in species from moist and intermediate conditions, but not for those typical of drier environments. Root traits were not significantly coordinated with leaf or stem traits within any of the three environments. The absence of a general and clear pattern of functional coordination when comparing results at different spatial scales could be due to the existence of different strategies operating at different levels. In this regard,
Funk \& Cornwell (2013) suggested that trait variations among species within communities do not necessarily match the global pattern. At the global or landscape scale, abiotic factors may determine trait variation between communities in accordance with the economics spectrum (Wright et al. 2004) and also by variation in growth forms (i.e. deciduous/evergreen species; Wright et al. 2005). In our study, the whole set of species (including different growth forms) belonging to different communities was dispersed along the major acquisitive-conservative axis (see Fig. 2), resulting in high functional coordination between organs. At the local scale, within a similar environment, the diversification of successful strategies is limited within the range of viable functional traits that allow plants to persist in a particular environment. Thus, if we focus on a smaller spatial scale (a restricted fraction of the environmental gradient), functional coordination among organs is not as evident as at a higher spatial scale (Appendix S8). At a higher spatial scale, soil resource limitation (mainly water shortage) could likely function as an initial abiotic filter, excluding those species of the community with inappropriate trait values, whereas other factors could promote functional changes at a lower spatial scale.

Most studies have focused on trait coordination along natural wide environmental gradients (Wright et al. 2004; Tjoelker et al. 2005; Baraloto et al. 2010; Fortunel et al. 2012) or changing greenhouse (or laboratory) conditions (Reich et al. 1998b; Hernández et al. 2010). However, fewer studies have compared trait coordination within the same environmental conditions (but see Reich et al. 1997; Craine et al. 2005; Funk \& Cornwell 2013). Similarly, Craine et al. (2005) analysed trait coordination among organs (leaf and root) in different grass communities, finding coordination for only one of the six traits analysed (leaf and root $\mathrm{N}$ concentration), in accordance with the results of our study. Since at the local scale of our study only a relatively small data set of species was analysed within each of the three environments, more studies in Mediterranean and other biomes are needed to confirm the generality of our findings.

\section{Variation in multidimensional functional traits}

Plant functional traits vary along three main dimensions: resource use, plant height and seed mass (Westoby 1998; Westoby \& Wright 2006; Reich 2014). Although we expected orthogonal relationships between plant height and traits governing the plant resource economy, as found by Golodets et al. (2009) and Laughlin et al. (2010), our results refute that hypothesis. Instead, we found significant relationships between plant height and those leaf and root traits associated with higher resource acquisition. Hence, greater height implies increased ability to compete for 
above-ground resources such as light (Bernard-Verdier et al. 2012), and this strategy could be advantageous for acquisitive species inhabiting more productive and moister sites (Reich et al. 1992; Pérez-Ramos et al. 2012).

With regard to the reproductive functional dimension, our results indicate that regenerative (seed mass) and resource-use traits could be loaded on separate axes, as expected according to the LHS scheme (Westoby 1998). The reproductive dimension could be better explained through the reproductive effort strategy (Moles \& Westoby 2006), which entails a trade-off between seedling survival and number of seeds produced per square metre of canopy, rather than the acquisition-conservation axis that defines the plant economics spectrum. This finding supports previous studies in semi-arid forests (Laughlin et al. 2010) and Mediterranean grasslands (Liancourt et al. 2009), but contrasts with others that found a negative correlation between acquisitive traits (such as SLA or SRL) and seed mass in tree (Reich et al. 1998b) and grass species (Golodets et al. 2009). In our data set, seed mass was positively correlated with leaf density (a conservative trait), but this relationship depended on the phylogeny. Therefore, the orthogonality between vegetative and reproductive traits indicates that these functional traits may respond to different selective pressures of the environment (Liancourt et al. 2009) and the evolutionary context. However, due to the limitations of our study (we only considered one reproductive trait for a limited number of species), more studies are necessary to evaluate whether relationships between vegetative and reproductive traits can fulfil the above-mentioned predictions at a wider spatial scale.

\section{Relationships among functional traits at the community level}

At the community level, the links among traits belonging to different plant organs were consistently stronger than at the species level, in accordance with previous studies (Ackerly et al. 2002; Cingolani et al. 2007; Domínguez et al. 2012). According to our fourth hypothesis, dominant species will tend to have trait values that are better linked to their environments than those of less-abundant species, which could explain why the convergence of leaf, stem and root traits is stronger when using CWMs (Domínguez et al. 2012). To the best of our knowledge, our results also reveal - for the first time - the existence of a 'plant community economics spectrum' (sensu Pérez-Ramos et al. 2012) along a local environmental gradient in Mediterranean forests.

One of the advantages of this community-level approach is its potential ability to highlight relevant ecosystem processes and functioning that cannot be predicted from the physiology or functional structure of indi- vidual plant species present in the community (Suding et al. 2008). For example, the morphological and physiological traits of leaves, stems and roots (particularly those related to the plant economics spectrum) determine ecosystem processes such as plant primary productivity or litter decomposability (Birouste et al. 2012; Choat et al. 2012; Freschet et al. 2013). It is necessary also to highlight the importance of incorporating below-ground traits (especially of fine roots) into the functional analysis: first because fine roots represent approximately $48 \%$ of the annual litter input in forests (Freschet et al. 2013), and second because understanding coordination between above- and below-ground traits may facilitate future predictions of root traits from leaf traits; which are easier to quantify (Birouste et al. 2012).

With regard to the reproductive dimension, at the community level there was strong coordination between morphological traits and seed mass, despite this not being shown at the species level (Fig. 3). Thus, in plant communities dominated by species with a conservative strategy we would expect to find larger seeds, whereas the opposite tendency would hold for communities dominated by species with acquisitive strategies. Consistent with these findings, Golodets et al. (2009) found that correlations between seed mass and morphological traits (SLA and LDMC) were stronger at the community than at the species level. These results support the tolerance-fecundity model (Muller-Landau 2010). According to this model, communities dominated by small-seeded species (usually with higher fecundity) will be favoured in more productive sites, whereas large-seeded species will be more abundant in stressful habitats. Larger seeds produce larger seedlings, which are more robust and better able to escape size-dependent mortality (Pérez-Ramos et al. 2010); they form deeper and more extensive roots, which can potentially capture more soil water during the dry season (Quero et al. 2007). This apparent co-variation between morphological and reproductive traits found at the community level (but not across species) suggests that a combination of the economics spectrum with the tolerance-fecundity dimension could explain the most successful strategies of dominant woody plant species in Mediterranean environments.

\section{Conclusions}

Our results show a high degree of functional coordination between traits belonging to different plant organs (leaf, stem and root). In addition, morphological traits were highly correlated with plant size as well as with key physiology-related traits. All these results suggest that different plant organs might have some degree of convergence in resource use and resistance to physical 
hazards, supporting the hypothesis of integrated plant evolution (Kerkhoff et al. 2006; Freschet et al. 2010; Reich 2014). However, this general trend of coordination of functional traits between organs became weaker or disappeared when considering groups of species belonging to environmentall -similar sites. We also found that relationships among functional traits were consistently stronger at the community level than across species, supporting the hypothesis that dominant species are better suited to the local environment and shape the functional patterns of vegetation. Interestingly, the strong co-variation between vegetative (leaf, stem and root) and reproductive (seed) traits found at the community level suggests that in dominant species the economics spectrum and the tolerance-fecundity strategy could be coupled. Further studies in other floras and ecosystems throughout the world are necessary to obtain solid conclusions on functional coordination between plant organs on a larger global scale.

\section{Acknowledgements}

We thank Miguel Verdú for help with the phylogenetic tree and analyses and Jose Rafael Vera for plant trait analyses. We also thank Jardín Botánico de Córdoba (Francisca Herrera) and the Semillas Cantueso Company (José Angel Cantueso) for providing seed mass data. We are very grateful to Francesco de Bello for interesting comments on previous versions of the manuscript. This study was funded by the Spanish MEC coordinated project DIVERBOS (CGL2011-30285-C02-01 and C02-02), the Andalusian ANASINQUE project (PGC2010-RNM-5782), the Life + Biodehesa Project (11/BIO/ES/000726), ECO-MEDIT (CGL2014-53236-R) and European FEDER funds. Dr. David Walker revised the English.

\section{References}

Ackerly, D.D., Knight, C.A., Weiss, S.B., Barton, K. \& Starmer, K.P. 2002. Leaf size, specific leaf area and microhabitat distribution of chaparral woody plants: contrasting patterns in species level and community level analyses. Oecologia 130: 449-457.

Baraloto, C., Paine, C.E., Poorter, L., Beauchene, J., Bonal, D., Domenach, A.M., Hérault, B., Patiño, S., Roggy, J.C. \& Chave, J. 2010. Decoupled leaf and stem economics in rain forest trees. Letters, Ecology 13: 1338-1347.

Bernard-Verdier, M., Navas, M., Vellend, M., Violle, C., Fayolle, A. \& Garnier, E. 2012. Community assembly along a soil depth gradient: contrasting patterns of plant trait convergence and divergence in a Mediterranean rangeland. Journal of Ecology 100: 1422-1433.

Birouste, M., Kazakou, E., Blanchard, A. \& Roumet, C. 2012. Plant traits and decomposition: are the relationships for roots comparable to those for leaves? Annals of Botany 109: 463472.

Castroviejo, S. 1986-2012. Flora Iberica, vols. 1-8, 10-15, 17-18, 21. Real Jardín Botánico, CSIC, Madrid, ES.

Choat, B., Jansen, S., Brodribb, T.J., Cochard, H., Delzon, S., Bhaskar, R., Bucci, S.J., Feild, T.S., Gleason, S.M. (...) \& Zanne, A.E. 2012. Global convergence in the vulnerability of forests to drought. Nature 491: 752-755.

Cingolani, A.M., Cabido, M., Gurvich, D.E., Renison, D. \& Díaz, S. 2007. Filtering processes in the assembly of plant communities: are species presence and abundance driven by the same traits? Journal of Vegetation Science 18: 911920.

Cordlandwehr, V., Meredith, R.L., Ozinga, W.A., Bekker, R.M., Groenendael, J.M. \& Bakker, J.P. 2013. Do plant traits retrieved from a database accurately predict on-site measurements? Journal of Ecology 101: 662-670.

Craine, J.M., Lee, W.G., Bond, W.J., Williams, R.J. \& Johnson, L.C. 2005. Environmental constraints on a global relationship among leaf and root traits of grasses. Ecology 86: 12-19.

de la Riva, E.G., Pérez-Ramos, I., Fernández, C.N., Olmo, M., Arana, T.M. \& Villar, R. 2014. Rasgos funcionales en el género Quercus: estrategias adquisitivas frente a conservativas en el uso de recursos. Ecosistemas 23: 82-89.

de la Riva, E.G., Pérez-Ramos, I.M., Tosto, A., NavarroFernández, C.M., Olmo, M., Marañón, T. \& Villar, R. 2015. Disentangling the relative importance of species occurrence, abundance and intraspecific variability in community assembly: a trait-based approach at the whole plant level in Mediterranean forests. Oikos. doi:10.1111/ oik.01875.

Díaz, S., Hodgson, J.G., Thompson, K., Cabido, M., (...) \& Zak, M.R. 2004. The plant traits that drive ecosystems: evidence from three continents. Journal of Vegetation Science 15: 295304.

Dixon, P. 2003. VEGAN, a package of R functions for community ecology. Journal of Vegetation Science 14: 927-930.

Domínguez, M.T., Aponte, C., Pérez-Ramos, I.M., García, L.V., Villar, R. \& Marañón, T. 2012. Relationships between leaf morphological traits, nutrient concentrations and isotopic signatures for Mediterranean woody plant species and communities. Plant and Soil 357: 407-424.

Evans, J.R. \& Poorter, H. 2001. Photosynthetic acclimation of plants to growth irradiance: the relative importance of specific leaf area and nitrogen partitioning in maximizing carbon gain. Plant, Cell $\theta$ Environment 24: 755-767.

Farquhar, G.D., Learyb, M.H.O. \& Berry, J.A. 1982. On the relationship between carbon isotope discrimination and the intercellular carbon dioxide concentration in leaves. Australian Journal of Plant Physiology 9: 121-137.

Fernández-Mazuecos, M. \& Vargas, P. 2010. Ecological rather than geographical isolation dominates Quaternary formation of Mediterranean Cistus species. Molecular Ecology 19: 13811395. 
Fortunel, C., Fine, P.V. \& Baraloto, C. 2012. Leaf, stem and root tissue strategies across 758 Neotropical tree species. Functional Ecology 26: 1153-1161.

Freschet, G.T., Cornelissen, J.H.C., van Logtestijn, R.S.P. \& Aerts, R. 2010. Evidence of the "plant economics spectrum" in a subarctic flora. Journal of Ecology 98: 362-373.

Freschet, G.T., Cornwell, W.K., Wardle, D.A., Elumeeva, T.G., Liu, W., Jackson, B., (...) \& Conelissen, H.C. 2013. Linking litter decomposition of above- and below-ground organs to plant-soil feedbacks worldwide. Journal of Ecology 101: 943952.

Funk, J.L. \& Cornwell, W.K. 2013. Leaf traits within communities: context may affect the mapping of traits to function. Ecology 94: 1893-1897.

García-Fayos, P. 2001. Bases ecológicas para la recolección, almacenamiento y germinación de semillas de especies de uso forestal de la Comunidad Valenciana. Banc de Llavors Forestals (Generalitat Valenciana), ES.

Garnier, E. \& Navas, M.L. 2012. A trait-based approach to comparative functional plant ecology: concepts, methods and applications for agroecology. Agronomy for Sustainable Development 32: 365-399.

Garnier, E., Cortez, J., Billes, G., Navas, M.L., Roumet, C., Debussche, M., (...) \& Toussaint, J.P. 2004. Plant functional markers capture ecosystem properties. Ecology 85: 26302637.

Golodets, C., Sternberg, M. \& Kigel, J. 2009. A community level test of the leaf height seed ecology strategy scheme in relation to grazing conditions. Journal of Vegetation Science 20: 392-402.

Heberling, J.M. \& Fridley, J.D. 2012. Biogeographic constraints on the world-wide leaf economics spectrum. Global Ecology and Biogeography 21: 1137-1146.

Hernández, E.I., Vilagrosa, A., Pausas, J.G. \& Bellot, J. 2010. Morphological traits and water use strategies in seedlings of Mediterranean coexisting species. Plant Ecology 207: 233244.

Kembel, S.W. \& Cahill, J.F. 2011. Independent evolution of leaf and root traits within and among temperate grassland plant communities. PLOS ONE 6: el 9992.

Kerkhoff, A.J., Fagan, W.F., Elser, J.J. \& Enquist, B.J. 2006. Phylogenetic and growth form variation in the scaling of nitrogen and phosphorus in the seed plants. The American Naturalist 168: 103-122.

Klein, C.H. 2007. Lecture Notes for the Teaching Module Forest Inventory. Institute of Forest Management, Faculty of Forest Sciences and Forest Ecology. Georg August Universität, DE, $164 \mathrm{p}$.

Laughlin, D.C. 2014. The intrinsic dimensionality of plant traits and its relevance to community assembly. Journal of Ecology 102: 186-193.

Laughlin, D.C., Leppert, J.J., Moore, M.M. \& Sieg, C.H. 2010. A multi-trait test of the leaf-height-seed plant strategy scheme with 133 species from a pine forest flora. Functional Ecology 24: 493-501.
Lavorel, S., Grigulis, K., McIntyre, S., Williams, N.S., Garden, D., (...) \& Bonis, A. 2008. Assessing functional diversity in the fieldmethodology matters! Functional Ecology 22: 134-147.

Lê, S., Josse, J. \& Husson, F. 2008. FactoMineR: an R package for multivariate analysis. Journal of Statistical Software 25: 1-18.

Liancourt, P., Tielbörger, K., Bangerter, S. \& Prasse, R. 2009. Components of 'competitive ability' in the LHS model: implication on coexistence for twelve co-occurring Mediterranean grasses. Basic and Applied Ecology 10: 707-714.

Liu, G., Freschet, G.T., Pan, X., Cornelissen, J.H.C., Li, Y. \& Dong, M. 2010. Coordinated variation in leaf and root traits across multiple spatial scales in Chinese semi-arid and arid ecosystems. New Phytologist 188: 543-553.

Manos, P.S., Doyle, J.J. \& Nixon, K.C. 1999. Phylogeny, biogeography, and processes of molecular differentiation in Quercus subgenus Quercus (Fagaceae). Molecular Phylogenetics and Evolution 12: 333-349.

Méndez-Alonzo, R., Paz, H., Zuluaga, R.C., Rosell, J.A. \& Olson, M.E. 2012. Coordinated evolution of leaf and stem economics in tropical dry forest trees. Ecology 93: 2397-2406.

Moles, A.T. \& Westoby, M. 2006. Seed size and plant strategy across the whole life cycle. Oikos 113: 91-105.

Muller-Landau, H.C. 2010. The tolerance-fecundity trade-off and the maintenance of diversity in seed size. Proceedings of the National Academy of Sciences of the United States of America 107: 4242-4247.

Paradis, E., Claude, J. \& Strimmer, K. 2004. APE: analyses of phylogenetics and evolution in R language. Bioinformatics 20 : 289-290.

Pérez-Harguindeguy, N., Díaz, S., Garnier, E., Lavorel, S., Poorter, H., (...) \& Cornelissen, J.H.C. 2013. New handbook for standardised measurement of plant functional traits worldwide. Australian Journal of Botany 61: 167-234.

Pérez-Ramos, I.M., Gómez-Aparicio, L., Villar, R., Garcia, L.V. \& Marañón, T. 2010. Seedling growth and morphology of three oak species along field resource gradients and seed mass variation: a seedling age-dependent response. Journal of Vegetation Science 21: 419-437.

Pérez-Ramos, I.M., Roumet, C., Cruz, P., Blanchard, A., Autran, P. \& Garnier, E. 2012. Evidence for a "plant community economics spectrum" driven by nutrient and water limitations in a Mediterranean rangeland of southern France. Journal of Ecology 100: 1315-1327.

Poorter, H. \& Garnier, E. 2007. Ecological significance of inherent variation in relative growth rate and its components. In: Punnaire, F.I. \& Valladares, F. (eds.) Functional Plant Ecology, 2nd edn, pp. 67-100. CRC Press, Boca Raton, FL, US.

Pratt, R.B., Jacobsen, A.L., Ewers, F.W. \& Davis, S.D. 2007. Relationships among xylem transport, biomechanics and storage in stems and roots of nine Rhamnaceae species of the California chaparral. New Phytologist 174: 787-798.

Prieto, I., Roumet, C., Cardinael, R., Dupraz, C., Jourdan, C., Kim, J.H., (...) \& Stokes, A. 2015. Root functional parameters along a land-use gradient: evidence of a 
community-level economics spectrum. Journal of Ecology 103: 361-373.

Quero, J.L., Villar, R., Marañón, T., Zamora, R. \& Poorter, L. 2007. Seed-mass effects in four Mediterranean Quercus species (Fagaceae) growing in contrasting light environments. American Journal of Botany 94: 1795-1803.

Reich, P.B. 2014. The worldwide 'fast-slow' plant economics spectrum: a traits manifesto. Journal of Ecology 102: 275-301.

Reich, P.B., Walters, M.B. \& Ellsworth, D.S. 1992. Leaf life-span in relation to leaf, plant, and stand characteristics among diverse ecosystems. Ecological Monographs 62: 365-392.

Reich, P.B., Walters, M.B. \& Ellsworth, D.S. 1997. From tropics to tundra: global convergence in plant functioning. Proceedings of the National Academy of Sciences 94: 13730-13734.

Reich, P.B., Walters, M.B., Tjoelker, M.G., Vanderklein, D. \& Buschena, C. 1998a. Photosynthesis and respiration rates depend on leaf and root morphology and nitrogen concentration in nine boreal tree species differing in relative growth rate. Functional Ecology 12: 395-405.

Reich, P.B., Tjoelker, M.G., Walters, M.B., Vanderklein, D.W. \& Buschena, C. 1998b. Close association of RGR, leaf and root morphology, seed mass and shade tolerance in seedlings of nine boreal tree species grown in high and low light. Functional Ecology 12: 327-338.

Revell, L.J. 2012. Phytools: an R package for phylogenetic comparative biology (and other things). Methods in Ecology and Evolution 3: 217-223.

Seibt, U., Rajabi, A., Griffiths, H. \& Berry, J.A. 2008. Carbon isotopes and water use efficiency: sense and sensitivity. Oecologia 155: 441-454.

Silva, J.S. \& Rego, F.C. 2004. Root to shoot relationships in Mediterranean woody plants from Central Portugal. Biologia 59: 1-7.

Suding, K.N., Lavorel, S., Chapin, F.S., Cornelissen, J.H.C., Díaz, S., (...) \& Navas, M.L. 2008. Scaling environmental change through the community-level: a trait-based response-andeffect framework for plants. Global Change Biology 14: 11251140.

Tjoelker, M.G., Craine, J.M., Wedin, D., Reich, P.B. \& Tilman, D. 2005. Linking leaf and root trait syndromes among 39 grassland and savannah species. New Phytologist 167: 493-508.

Verdú, M. \& Pausas, J.G. 2013. Syndrome driven diversification in a Mediterranean ecosystem. Evolution 67: 1756-1766.

Villar, R., Robleto, J.R., De Jong, Y. \& Poorter, H. 2006. Differences in construction costs and chemical composition between deciduous and evergreen woody species are small as compared to differences among families. Plant, Cell and Environment 29: 1629-1643.
Violle, C., Navas, M.L., Vile, D., Kazakou, E., Fortunel, C., Hummel, I. \& Garnier, E. 2007. Let the concept of trait be functional! Oikos 116: 882-892.

Warton, D.I., Wright, I.J., Falster, D.S. \& Westoby, M. 2006. Bivariate line-fitting methods for allometry. Biological Reviews 81:259-291.

Warton, D.I., Duursma, R.A., Falster, D.S. \& Taskinen, S. 2012. Smatr 3-an R package for estimation and inference about allometric lines. Methods in Ecology and Evolution 3: 257-259.

Webb, C.O., Ackerly, D.D. \& Kembel, S.W. 2008. Phylocom: software for the analysis of phylogenetic community structure and trait evolution. Bioinformatics 24: 2098-2100.

Westoby, M. 1998. A leaf-height-seed (LHS) plant ecology strategy scheme. Plant and Soil 199: 213-227.

Westoby, M. \& Wright, I.J. 2006. Land-plant ecology on the basis of functional traits. Trends in Ecology $\theta$ Evolution 2 1: 261-268.

Witkowski, E.T.F. \& Lamont, B.B. 1991. Leaf specific mass confounds leaf density and thickness. Oecologia 88: 486-493.

Wright, I.J. \& Westoby, M. 2001. Understanding seedling growth relationships through specific leaf area and leaf nitrogen concentration: generalisations across growth forms and growth irradiance. Oecologia 127: 21-29.

Wright, I.J., Reich, P.B., Westoby, M., Ackerly, D.D., Baruch, Z., (...) \& Villar, R. 2004. The worldwide leaf economics spectrum. Nature 428: 821-827.

Wright, I.J., Reich, P.B., Cornelissen, J.H., Falster, D.S., Groom, P.K., (...) \& Westoby, M. 2005. Modulation of leaf economic traits and trait relationships by climate. Global Ecology and Biogeography 14: 41 1-421.

\section{Supporting Information}

Additional Supporting Information may be found in the online version of this article:

Appendix S1. Species list.

Appendix S2. Functional traits list.

Appendix S3. Phylogenetic tree.

Appendix S4. Pearson correlation coefficients between traits.

Appendix S5. Relationships between morphological traits, carbon isotope fraction and leaf chlorophyll.

Appendix S6. Phylogenetic generalized least square analysis.

Appendix S7. Non-metric multidimensional scaling analysis.

Appendix S8. Illustration of the scale effects. 
Appendix S1. Species studied, abbreviations and plant abundance (\%) in the different sampling sites. T, tree; ST, small tree or arborescent shrub; S, shrub; D, deciduous; E, evergreen.

\begin{tabular}{|c|c|c|c|c|c|c|c|c|c|c|c|c|}
\hline \multirow{2}{*}{ Species } & \multirow{2}{*}{ Family } & \multirow{2}{*}{$\begin{array}{c}\text { Life } \\
\text { habit }\end{array}$} & \multirow{2}{*}{$\begin{array}{c}\text { Leaf } \\
\text { habit }\end{array}$} & \multicolumn{3}{|c|}{ Virgen de Linares } & \multicolumn{3}{|c|}{ Baños de Popea } & \multicolumn{3}{|c|}{ Las Tonadas } \\
\hline & & & & Upper & Medium & Lower & Upper & Medium & Lower & Upper & Medium & Lower \\
\hline Alnus glutinosa & Betulaceae & $\mathrm{T}$ & $\mathrm{D}$ & - & - & - & - & - & 27.23 & - & - & 12.65 \\
\hline Arbutus unedo & Ericaceae & ST & E & - & - & - & 5.25 & - & - & 19.63 & 3.62 & - \\
\hline Celtis australis & Cannabaceae & $\mathrm{T}$ & D & - & - & 18.34 & - & - & - & - & - & - \\
\hline Cistus albidus & Cistaceae & $\mathrm{S}$ & $\mathrm{E}$ & 19.16 & 2.58 & - & 2.83 & - & - & 4.88 & - & - \\
\hline Cistus crispus & Cistaceae & S & $\mathrm{E}$ & 7.35 & - & - & & - & - & - & - & - \\
\hline Cistus ladanifer & Cistaceae & S & $\mathrm{E}$ & 4.29 & - & - & 10.49 & - & - & 10.8 & - & - \\
\hline Cistus monspeliensis & Cistaceae & s & E & - & - & - & - & - & - & - & 2.8 & - \\
\hline Cistus salviifolius & Cistaceae & $\mathrm{s}$ & $\mathrm{E}$ & - & 7.74 & - & & - & - & - & - & - \\
\hline Crataegus monogyna & Rosaceae & ST & D & - & - & 5.27 & - & - & - & - & - & - \\
\hline Cydonia oblonga & Rosaceae & $\mathrm{T}$ & D & - & - & - & - & - & - & - & 2.25 & - \\
\hline Ficus carica & Moraceae & $\mathrm{T}$ & D & - & - & - & - & - & 10.12 & - & - & - \\
\hline Fraxinus angustifolia & Oleaceae & $\mathrm{T}$ & D & - & - & - & - & - & 30.6 & - & - & 37.96 \\
\hline Genista hirsuta & Fabaceae & S & $\mathrm{E}$ & 5.92 & 4.78 & - & 13.27 & - & - & 15.15 & - & - \\
\hline Jasminum fruticans & Oleaceae & s & $\mathrm{E}$ & - & - & - & - & 7.02 & - & - & - & - \\
\hline Lavandula stoechas & Lamiaceae & s & $\mathrm{E}$ & 4.32 & 2.58 & - & - & - & - & - & - & - \\
\hline Myrtus communis & Mirtaceae & S & $\mathrm{E}$ & - & 6.89 & - & - & 2.72 & - & 4.48 & - & - \\
\hline Nerium oleander & Apocynaceae & ST & $\mathrm{E}$ & - & - & 11.71 & - & 5.22 & 7.21 & - & - & - \\
\hline Phlomis purpurea & Lamiaceae & S & $\mathrm{E}$ & 5.56 & - & - & - & - & - & - & - & - \\
\hline Phillyrea angustifolia & Oleaceae & ST & $\mathrm{E}$ & - & - & - & 4.62 & - & - & 9.1 & 4.36 & - \\
\hline Phillyrea latifolia & Oleaceae & ST & $\mathrm{E}$ & - & - & - & - & 45.05 & - & - & - & - \\
\hline Pistacia lentiscus & Anacardiaceae & ST & $\mathrm{E}$ & 10.02 & 33.61 & 17.63 & - & 2.99 & - & - & 5.65 & - \\
\hline Pistacia terebinthus & Anacardiaceae & ST & D & - & - & - & - & 2.54 & - & - & - & - \\
\hline Populus alba & Salicaceae & $\mathrm{T}$ & D & - & - & - & - & - & - & - & - & 6.68 \\
\hline Pyrus bourgaeana & Rosaceae & $\mathrm{T}$ & D & - & - & - & - & - & - & - & 7.22 & - \\
\hline Quercus coccifera & Fagaceae & ST & $\mathrm{E}$ & 19.71 & 7.74 & - & 23.5 & 7.37 & - & 9.29 & 7.96 & - \\
\hline Quercus faginea & Fagaceae & $\mathrm{T}$ & D & - & - & - & - & 2.65 & - & - & - & - \\
\hline Quercus ilex spp.ballota & a Fabaceae & $\mathrm{T}$ & $\mathrm{E}$ & 18.06 & 25.32 & - & - & - & - & 16.33 & 25.24 & - \\
\hline Rhamnus lycioides & Rhamnaceae & $\mathrm{S}$ & $\mathrm{E}$ & - & - & 5.64 & - & - & - & - & - & - \\
\hline Rosa canina & Rosaceae & S & D & - & - & - & - & - & - & - & 2.55 & - \\
\hline Rosmarinus officinalis & Lamiaceae & S & $\mathrm{E}$ & - & - & - & 31.06 & - & - & - & - & - \\
\hline Rubus ulmifolius & Rosaceae & s & $\mathrm{E}$ & - & - & 11.89 & - & - & 8.71 & - & 13.44 & 25.65 \\
\hline Ruscus aculeatus & Asparagaceae & $\mathrm{S}$ & $\mathrm{E}$ & - & - & - & - & 4.57 & - & - & 3.44 & - \\
\hline Salix atrocinerea & Salicaceae & $\mathrm{T}$ & D & - & - & - & - & & - & - & - & 6.21 \\
\hline Smilax aspera & Smilacaceae & s & $\mathrm{E}$ & - & - & - & - & 2.61 & - & - & - & - \\
\hline Teucrium fruticans & Lamiaceae & $S$ & $\mathrm{E}$ & - & - & - & 2.89 & - & - & - & - & - \\
\hline Ulmus minor & Ulmaceae & $\mathrm{T}$ & D & - & - & 17.21 & - & - & 7.13 & - & - & - \\
\hline Viburnum tinus & Adoxaceae & ST & $\mathrm{E}$ & - & - & - & - & 7.75 & - & - & 11.37 & - \\
\hline Vitis vinifera & Vitaceae & $s$ & D & - & - & 7.62 & - & - & - & - & - & - \\
\hline
\end{tabular}


Appendix S2. List of the 15 functional traits considered in this study, their abbreviations, units and main role in plant functioning (based on the literature: Farquhar et al. 1982; Bernard-Verdier et al. 2012; Garnier \& Navas 2012; Pérez-Harguindeguy et al. 2013).

\begin{tabular}{|c|c|c|c|c|}
\hline Group & Trait & Abbreviation & Unit & Functional role \\
\hline Leaf morphology & $\begin{array}{l}\text { Specific leaf area } \\
\text { Leaf dry matter content } \\
\text { Leaf thickness } \\
\text { Leaf density }\end{array}$ & $\begin{array}{l}\text { SLA } \\
\text { LDMC } \\
\text { LThick } \\
\text { LD }\end{array}$ & $\begin{array}{l}\mathrm{m}^{2} \mathrm{~kg}^{-1} \\
\mathrm{mg} \mathrm{g}^{-1} \\
\mathrm{~mm}^{-} \\
\mathrm{g} \mathrm{cm}^{-3}\end{array}$ & $\begin{array}{l}\text { Light capture and growth rate } \\
\text { Physical resistance and stress tolerance } \\
\text { Gas exchange, water retention and physical resistance } \\
\text { Physical resistance, growth rate and stress tolerance }\end{array}$ \\
\hline Stem morphology & $\begin{array}{l}\text { Stem dry matter content } \\
\text { Stem wood density }\end{array}$ & $\begin{array}{l}\text { SDMC } \\
\text { SWD }\end{array}$ & $\begin{array}{l}\mathrm{mg} \mathrm{g}^{-1} \\
\mathrm{~g} \mathrm{~cm}^{-} 3\end{array}$ & $\begin{array}{l}\text { Resistance to physical hazards } \\
\text { Physical resistance, growth rate and stress tolerance }\end{array}$ \\
\hline Root morphology & $\begin{array}{l}\text { Specific root area } \\
\text { Root dry matter content } \\
\text { Root diameter } \\
\text { Root density }\end{array}$ & $\begin{array}{l}\text { SRA } \\
\text { RDMC } \\
\text { Rdi } \\
\text { RD }\end{array}$ & $\begin{array}{l}\mathrm{m}^{2} \mathrm{~kg}^{-1} \\
\mathrm{mg} \mathrm{g} \\
\mathrm{mm} \\
\mathrm{g} \mathrm{cm}^{-}\end{array}$ & $\begin{array}{l}\text { Water and nutrients acquisition } \\
\text { Resistance to physical hazards } \\
\text { Physical resistance, growth rate and stress tolerance } \\
\text { Physical resistance, growth rate and stress tolerance }\end{array}$ \\
\hline Leaf Physiology & $\begin{array}{l}\text { Leaf nitrogen concentration } \\
\text { Leaf chlorophyll }{ }^{1} \\
\text { Isotopic carbon fraction }\end{array}$ & $\begin{array}{l}\mathrm{LN} \\
\mathrm{LChl} \\
\delta^{13} \mathrm{C}\end{array}$ & $\begin{array}{c}\% \\
\mu \mathrm{g} \mathrm{g} \\
\%\end{array}$ & $\begin{array}{l}\text { Light capture and photosynthetic rate } \\
\text { Light capture and photosynthetic rate } \\
\text { Gas exchange and water-use efficiency }\end{array}$ \\
\hline Plant Size & Plant height & Phg & $\mathrm{m}$ & Dispersal distance, light capture, above-ground competition \\
\hline Seed & Seed mass & Smass & $\mathrm{mg}$ & Dispersal capability and seedling survivorship \\
\hline
\end{tabular}

1 Based on fresh mass 
Appendix S3. The phylogenetic tree of the 38 studied species was obtained with the help of the Phylomatic program, as implemented in Phylocom 4.2, and the reference phylogeny contained in R20120829.new (Webb, Ackerly \& Kembel 2008).

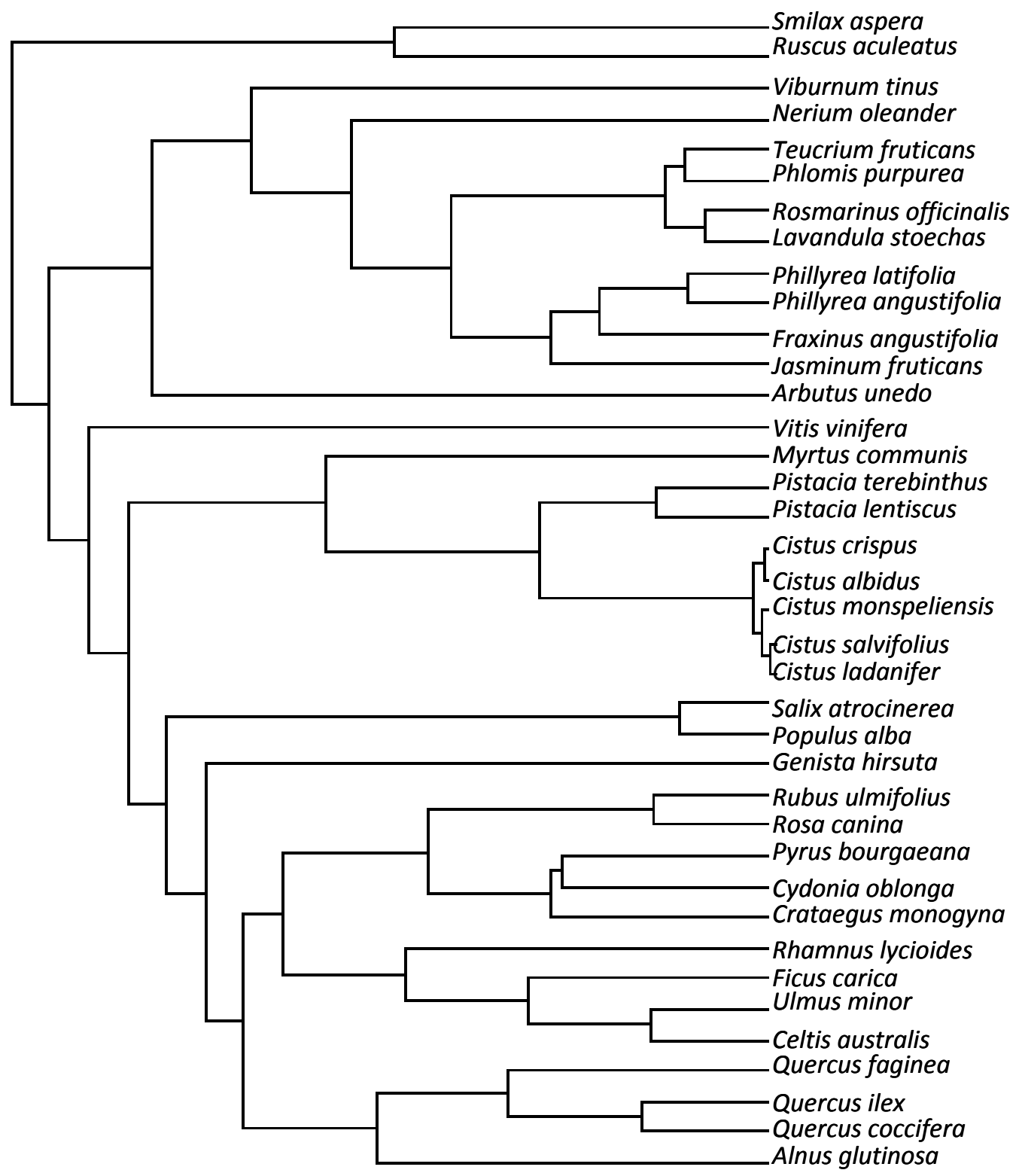

Webb, C.O., Ackerly, D.D. \& Kembel, S.W. 2008. Phylocom: software for the analysis of phylogenetic community structure and trait evolution. Bioinformatics 24: 2098-2100. 
Appendix S4. Pearson correlation coefficients for species data from the PCA analysis

(Fig.1). The significance level is as follows: $* P<0.05$, ** $P<0.01$, *** $P<0.001$.

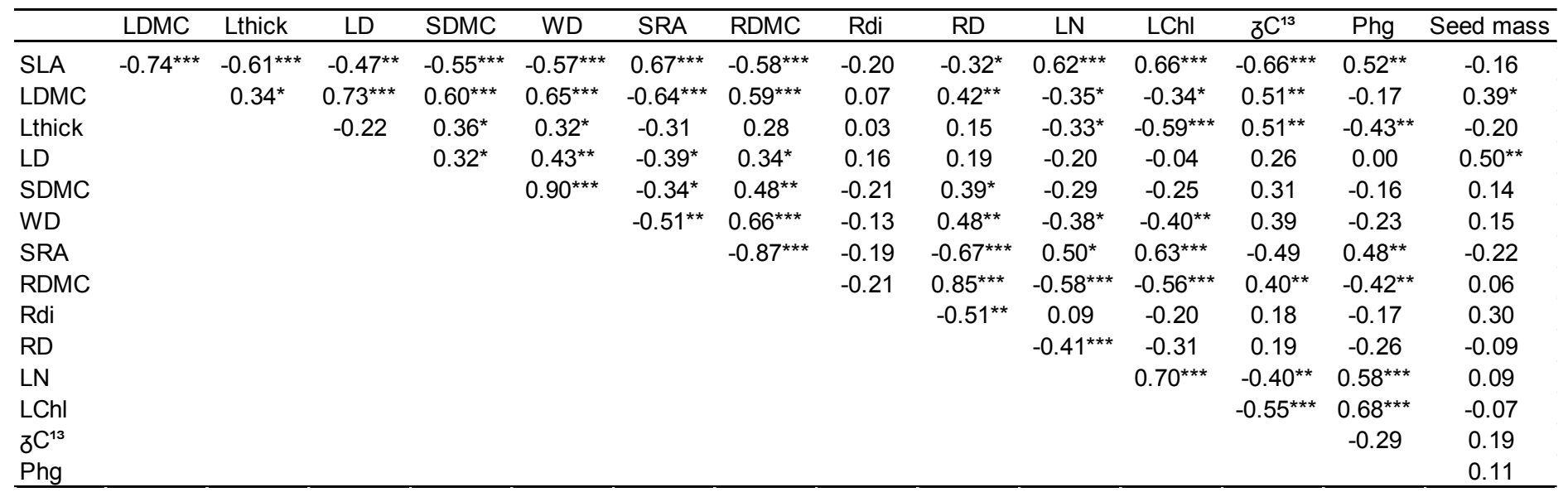


Appendix S5.- Relationships between morphological traits (leaf, black circles and solid lines; stem, grey circles and dotted lines; root, white circles and dashed lines) - ordered along an acquisitive-conservative gradient (given by the PCA first axis values) - and the isotopic carbon fraction $\left(\delta^{13} \mathrm{C}\right)$ and leaf chlorophyll ( $\left.\mathrm{LChl}\right)$, at the species (left column) and community (right column) levels. The Pearson correlation coefficient (r) is given and the standard major axis (SMA) regression line is plotted when significant. The significance level is as follows: $* P<0.05, * * P<0.01$, *** $P<0.001$.

\section{SPECIES}
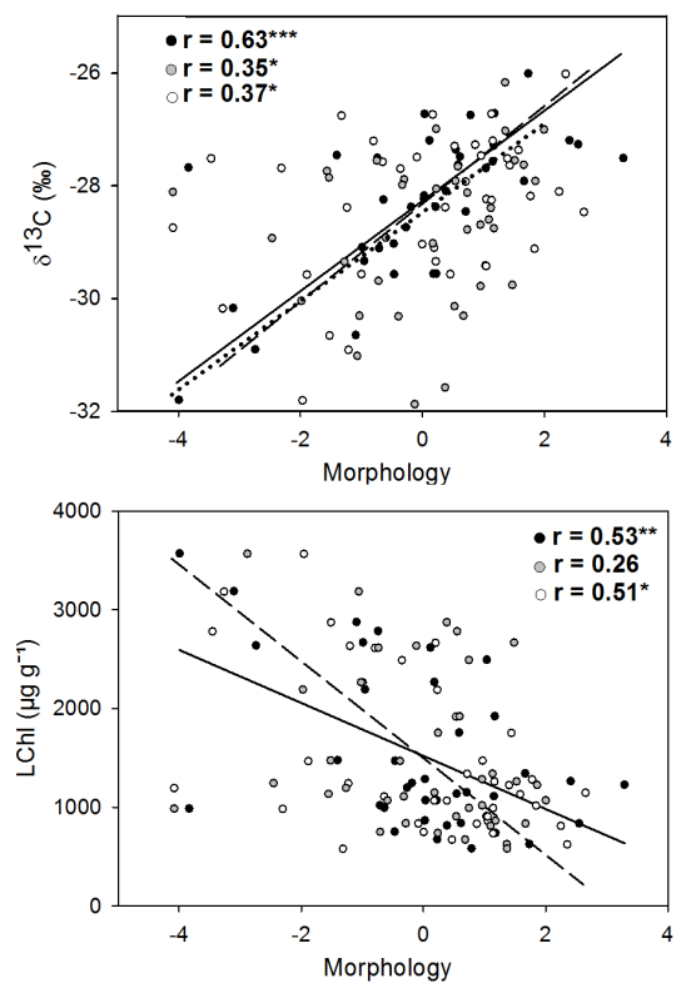

Acquisitive

\section{COMMUNITIES}
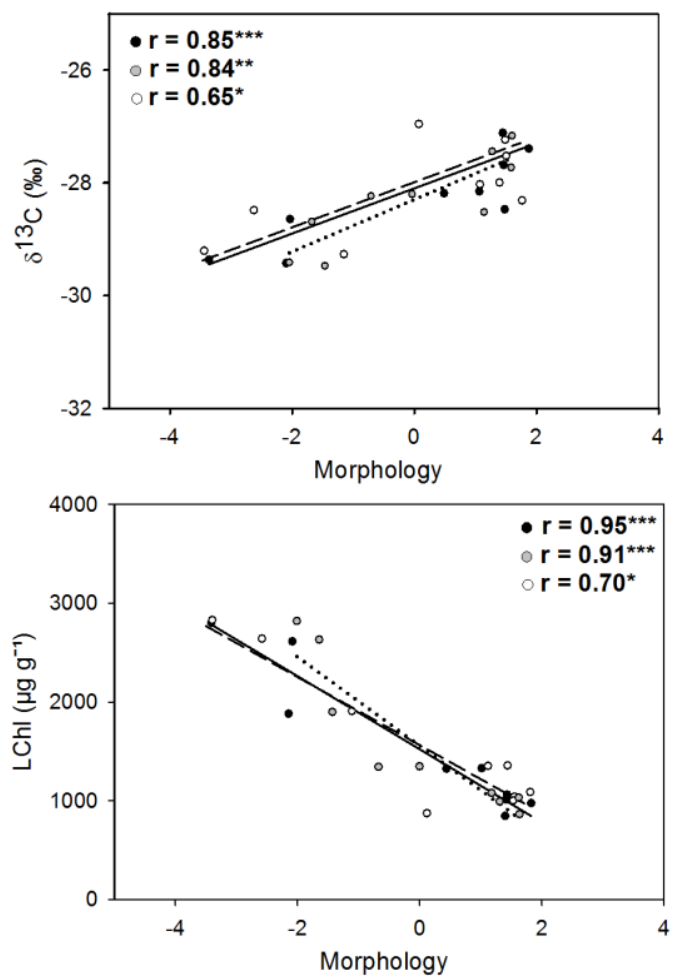

Conservative 
Appendix S6.- Results for the phylogenetic generalised least square (PGLS). The significant results $(P<0.05)$ show the phylogenetic independence for these relationships.

\begin{tabular}{|c|c|c|c|c|c|c|}
\hline & \multicolumn{2}{|c|}{ LEAF MORPHOLOGY } & \multicolumn{2}{|c|}{ STEM MORPHOLOGY } & \multicolumn{2}{|c|}{ ROOT MORPHOLOGY } \\
\hline & $\mathrm{P}$ & $\mathrm{R}^{2}$ & $\mathrm{P}$ & $\mathrm{R}^{2}$ & $\mathrm{P}$ & $\mathrm{R}^{2}$ \\
\hline LN & 0.01 & 0.15 & 0.05 & 0.07 & 0.00 & 0.23 \\
\hline LChl & $<0.001$ & 0.25 & ns & & $<0.001$ & 0.28 \\
\hline$\delta^{13} \mathrm{C}$ & $<0.001$ & 0.33 & 0.00 & 0.22 & 0.02 & 0.11 \\
\hline Phg & 0.06 & 0.06 & ns & & 0.01 & 0.14 \\
\hline Log(Smass) & ns & & ns & & ns & \\
\hline LEAF MORPHOLOGY & - & - & $<0.001$ & 0.38 & $<0.001$ & 0.28 \\
\hline STEM MORPHOLOGY & - & - & - & - & 0.00 & 0.21 \\
\hline
\end{tabular}


Appendix S7.- Non-metric multidimensional scaling (NDMS) ordination of species composition along the nine plant communities analysed, separating three groups: Wet (black circles), Medium (grey) and Dry (white) (see also de la Riva et al. 2015).

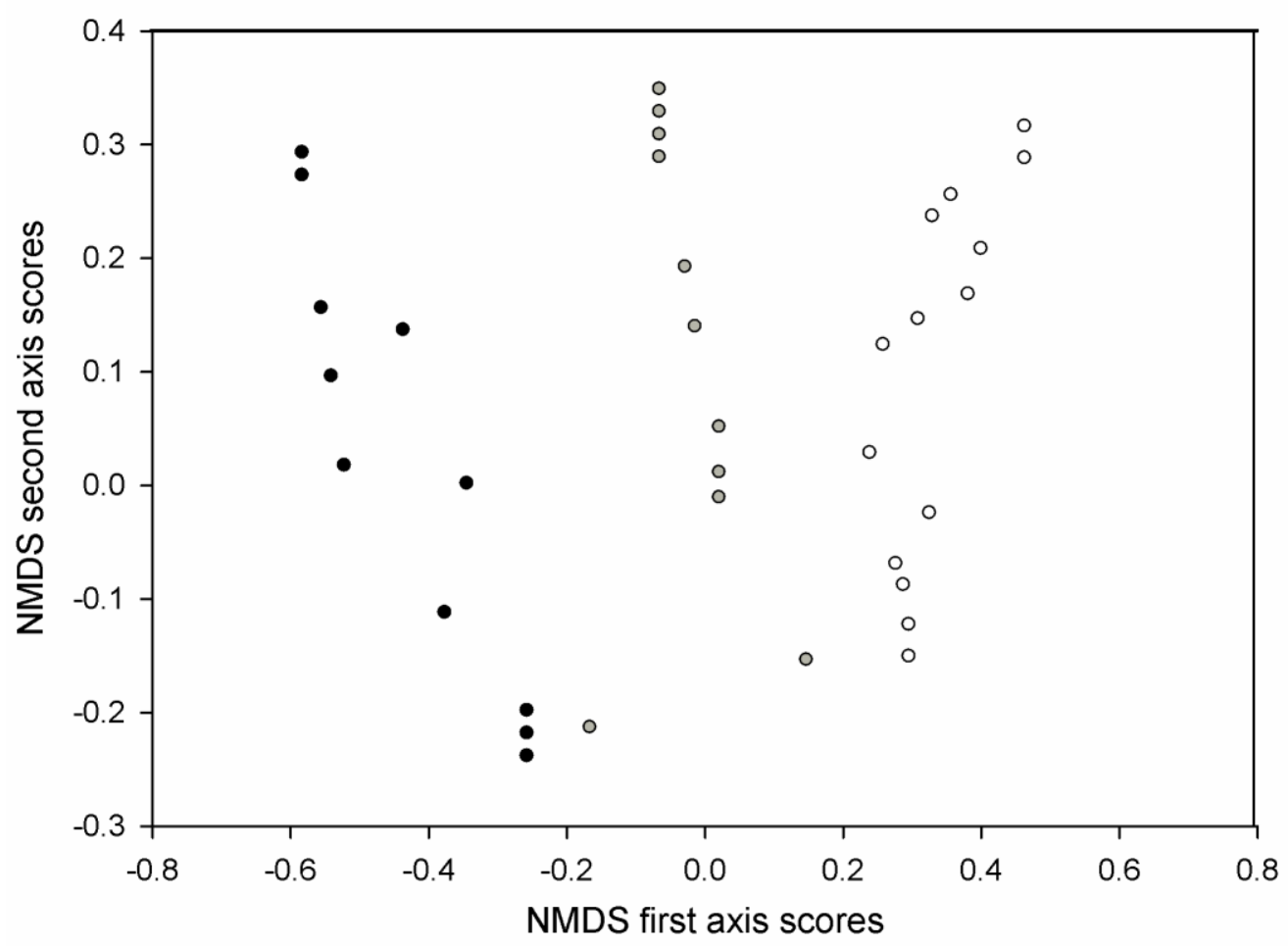


Appendix S8. Standardized Major Axis analysis illustrating the scale effects. Functional coordination between root and leaf morphology was compared at the landscape (i.e including the whole environmental gradient) and at a lower spatial scale (i.e. at three different points of the gradient). The high level of coordination found at the landscape level dissapeared at a lower spatial scale (particularly in dry enviornments; right panel). See Figures 2 and 4 for more details.

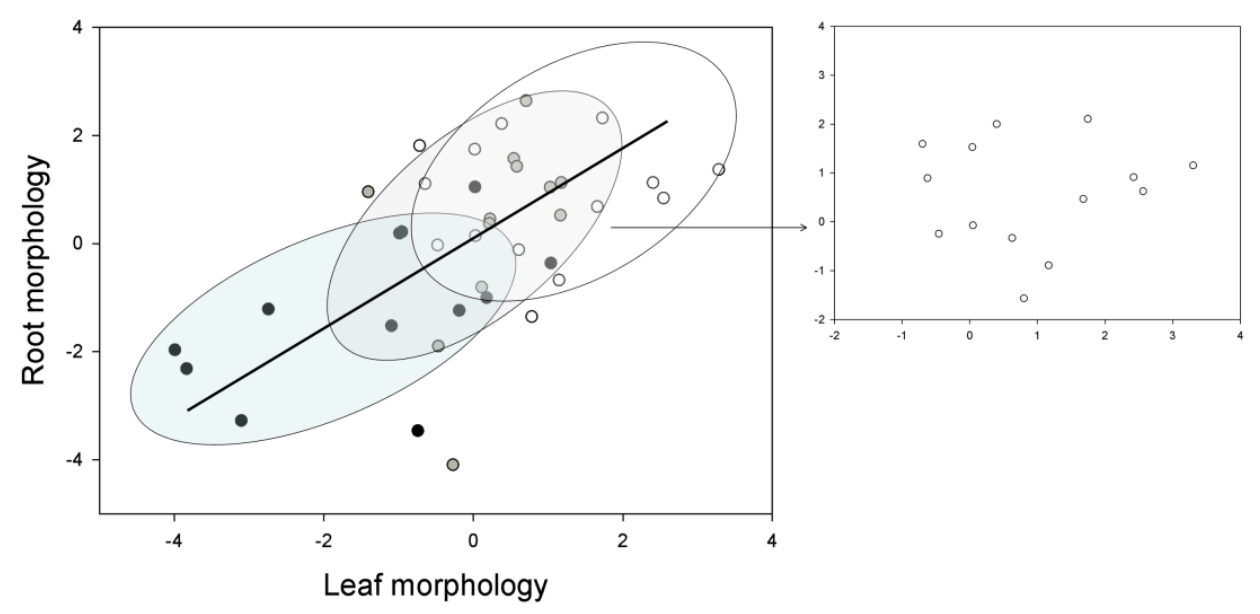





\section{Capitulo 4}

Disentangling the relative importance

of species occurrence, abundance and

intraspecific variability in community assembly:

a trait-based approach at the whole-plant level

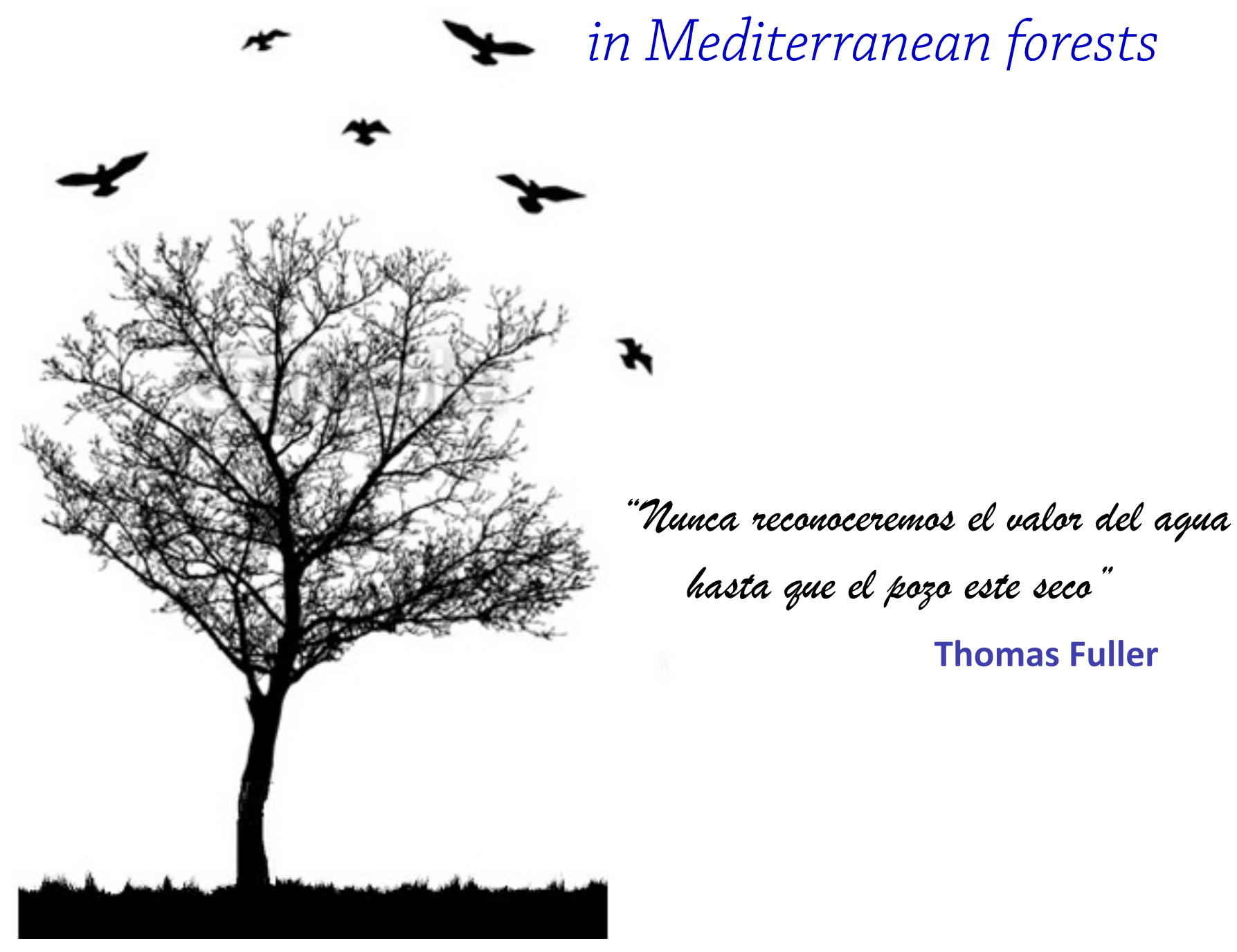





\title{
Disentangling the relative importance of species occurrence, abundance and intraspecific variability in community assembly: a trait-based approach at the whole-plant level in Mediterranean forests
}

\author{
Enrique G. de la Riva, Ignacio M. Pérez-Ramos, Ambra Tosto, Carmen M. Navarro-Fernández, \\ Manuel Olmo, Teodoro Marañón and Rafael Villar
}

E. G. de la Riva (enga70@gmail.com), A. Tosto, M. Olmo and R. Villar, Área de Ecología, Facultad de Ciencias, Univ. de Córdoba, ES-14071

Córdoba, Spain. - I. M. Pérez-Ramos, C. M. Navarro-Fernández and T. Marañón, Inst. de Recursos Naturales y Agrobiología de Sevilla, IRNAS, CSIC, ES-41012 Seville, Spain.

\begin{abstract}
Understanding which factors and rules govern the process of assembly in communities constitutes one of the main challenges of plant community ecology. The presence of certain functional strategies along broad environmental gradients can help to understand the patterns observed in community assembly and the filtering mechanisms that take place. We used a trait-based approach, quantifying variations in aboveground (leaf and stem) and belowground (root) functional traits along environmental gradients in Mediterranean forest communities (south Spain). We proposed a new practical method to quantify the relative importance of species turnover (distinguishing between species occurrence and abundance) versus intraspecific variation, which allowed us to better understand the assemblage rules of these plant communities along environmental gradients. Our results showed that the functional structure of the studied plant communities was highly determined by soil environment. Results from our modelling approach based on maximum likelihood estimators showed a predominant influence of soil water storage on most of the community functional traits. We found that changes in community functional structure along environmental gradients were mainly promoted by species turnover rather than by intraspecific variability. Specifically, our new method of variance decomposition demonstrated that between-site trait variation was the result of changes in species occurrence rather than in the abundance of certain dominant species. In conclusion, this study showed that water availability promoted the predominance of specific trait values (both in above and belowground fractions) associated to a resource acquisition or conservation strategy. In addition, we provided evidence that changes on community functional structure along the environmental gradient were mainly promoted by a process of species replacement, which represent a crucial step towards a more general understanding of the relative importance of intraspecific versus interspecific trait variation in these woody Mediterranean communities.
\end{abstract}

Understanding which factors and rules govern the process of species assembly in communities constitutes one of the main challenges of plant community ecology (Diamond 1975, Keddy 1992). To this end, the functional approach is a broadly-known key tool that emerged some years ago to better understand the mechanisms underlying community assembly along environmental gradients, as can be deduced from the large increase of published manuscripts on this specific issue (Lepš et al. 2011, Bernard-Verdier et al. 2012, Laliberté et al. 2012, Pérez-Ramos et al. 2012, Kichenin et al. 2013, Jung et al. 2014). Thus, the use of functional traits, i.e. 'morpho-physio-phenological attributes which have an indirect impact on fitness via their effects on growth, reproduction and survival' (Violle et al. 2007) is the base of numerous studies (trait-based) that scale-up from species to community level with the aim of attempting to explain the assembly rules of plant communities in diverse biomes (Violle et al. 2007, Shipley 2010, Garnier and Navas 2012). Most of these studies have focused on above-ground traits, mainly leaves (Ackerly et al. 2002, Bernard-Verdier et al. 2012, Domínguez et al. 2012, Spasojevic and Suding 2012, Kichenin et al. 2013) and stems (Cornwell and Ackerly 2009, Baraloto et al. 2010), probably due to the greater ease of their measurements compared with those of the belowground fraction (Holdaway et al. 2011). Thus, the role of root traits in the process of community assembly remains largely unexplored despite their recognized implications in plant-soil interactions and plant functional strategies (Silva and Rego 2003, Holdaway et al. 2011, McCormack et al. 2012). More insight will be thus gained from approaches including both the above and belowground fractions of plant communities. 
In Mediterranean ecosystems, strong environmental filters such as summer drought are expected to constrain the range of certain key functional traits of the community, selecting those species of the regional pool harbouring a set of attributes that enable them to persist in a particular site (Cornwell et al. 2006, Bernard-Verdier et al. 2012). In spite of the widely recognized importance of water availability as one of the main limiting resources for plants in Mediterranean ecosystems (Terradas 2001), recent studies in grassland communities have revealed a greater number of functional adaptations to soil nutrient scarcity than to drought (Ordoñez et al. 2009, Pérez-Ramos et al. 2012). Further trait-based studies are therefore essential to disentangle the relative importance of soil water and nutrient availability as drivers of plant community assembly in Mediterranean ecosystems, particularly for woody plant species.

Changes in community functional structure (i.e. trait composition at the community level) in response to environmental filters may be due to the turnover of species with different trait values (interspecific variation), to withinspecies changes in trait values (intraspecific variability) or to both processes acting simultaneously (Garnier et al. 2004, Albert et al. 2010a). In turn, interspecific variation can be decomposed into two different components of species turnover (Jung et al. 2014) due to changes in species occurrence (qualitative component) or species abundance (quantitative component). The quantification of these two components of species turnover may be relevant for determining which ecological processes are governing the rules of community assembly (Cingolani et al. 2007). On the one hand, changes in species occurrence seem to be associated with habitat filtering, either as a result of abiotic factors which imposes strong constraints on local trait distributions selecting only those species with suitable traits for limiting abiotic conditions (Keddy 1992, Cleland et al. 2011) or as a result of superior competitors which could promote disproportionally large effect on local resources, acting as abiotic constraints (Chesson 2000, Gross et al. 2013). On the other hand, changes in species abundance seem to result mainly from biotic interactions (facilitation or competition), which promote trait dissimilarity resulting from niche differentiation and allow coexistence by decreasing competition (MacArthur and Levins 1967, Stubb and Wilson 2004, Gross et al. 2009, Bernard-Verdier et al. 2012, Siefert 2012). However, to our knowledge, how species occurrence and abundance contribute to changes in community trait composition has not been partitioned yet along environmental gradients. To disentangle both sources of variability, we propose here a practical and simple method (modified from Lepš et al. 2011) to quantify the relative importance of species occurrence versus species abundance on changes in community functional structure, which will contribute for a better understanding of community assembly rules under particular environmental constraints.

In this study, our main objective was to discern which abiotic factors and mechanisms govern the process of community assembly along broad environmental gradients in Mediterranean forests of southern Spain. To accomplish this goal, we used a trait-based approach quantifying both aboveground (leaf and stem) and belowground (root) functional traits related to resource acquisition and plant structure. First, we identified which environmental drivers were best associated with functional trait variation and species distribution at the community level along a local environmental gradient. Second, we applied a new method to quantify the relative importance of species turnover (disentangling between species occurrence and abundance) versus intraspecific variation as mechanisms underlying changes in community functional structure along the explored environmental gradients.

\section{Material and methods}

\section{Study area}

The Mediterranean forests studied are located in Sierra Morena mountains, in the south of Spain (Córdoba). The area is characterized by a continental-Mediterranean climate with cold, wet winters and dry, warm summers. Mean annual temperature is $17.6^{\circ} \mathrm{C}$ (with maximum values in summer reaching $40^{\circ} \mathrm{C}$ ) and mean annual precipitation is $536 \mathrm{~mm}$ (with a three-month period in summer without rainfall; data from AEMET for the years 1971-2000). Bedrock is formed by siliceous substratum, which produces neutral or slightly acid soils (Leptosols). Shrub species such as Cistus albidus, Genista hirsuta, Quercus coccifera and Rosmarinus officinalis are abundant on upper slopes and hilltops, while broadleaf deciduous trees such as Alnus glutinosa, Celtis australis, Fraxinus angustifolia and Ulmus minor are dominant in valley bottoms (Supplementary material Appendix 1 Table A1-A2).

\section{Sampling design}

Nine sampling sites distributed over three different southfacing slopes (with at least $10 \mathrm{~km}$ of separation between them, and no climatic differences between them, Supplementary material Appendix 1 Table A3) were selected along a topographic gradient (from ridges to valley bottoms) with the aim of spanning a broad range of variations in soil resource availability (Supplementary material Appendix 1). Four $20 \mathrm{~m}$-long transects in each sampling site were randomly set up, perpendicular to the slope and parallel among them, with a minimum distance of $10 \mathrm{~m}$ relative to one another. In the spring of 2012, species abundance and composition were determined measuring the cover of each woody species intercepted by each of the four $20 \mathrm{~m}$ lines (total abundance can exceed $20 \mathrm{~m}$ since the overlapping vegetation layers were taken into account). The mean relative abundance for each species and site was calculated as the mean value of the four transects. For trait measurements, we ranked them by their relative abundances and selected those species representing at least the $90 \%$ of the total plant woody abundance measured in each site. This resulted in a total of 38 different sampled species, many of them appearing in more than one sampling site (Supplementary material Appendix 1 Table A2).

\section{Characterization of the environment}

Different soil characteristics were measured in each of the nine sampling sites. In May 2012, two soil samples per transect were taken using an auger up to a maximum depth of one meter. These soil samples were collected within a 
short period of time (three consecutive days) to avoid possible differences among sites derived from weather. Soil water content was quantified by the gravimetric method, i.e. weighing fresh soil samples and re-weighing them after being oven-dried at $100^{\circ} \mathrm{C}$ for $48 \mathrm{~h}$. From these measurements, we calculated an integrative variable of the whole soil profile for each of the 36 transects (soil water storage, SWS) as: (fresh soil mass - dry soil mass)/ area of the auger section $\left(5 \mathrm{~cm}^{2}\right)$.

Two additional soil samples of the top $20 \mathrm{~cm}$ of depth (where nutrient uptake mostly occurs; Jobbágy and Jackson 2001) were collected in each transect and further mixed to make a combined soil sample per transect, using this for physico-chemical analysis. In the laboratory, samples were air-dried, crushed and sieved; the fraction of less than $2 \mathrm{~mm}$ was analyzed using standard soil methods (Sparks 1996). The $\mathrm{pH}$ was measured in a 1:2.5 soil: water suspension; soil organic matter was determined by Walkley and Black method and total $\mathrm{N}$ was determined by Kjeldahl digestion. Available $\mathrm{P}$ was estimated by Olsen method; $\mathrm{Ca}, \mathrm{K}$ and $\mathrm{Mg}$ were extracted with $1 \mathrm{M}$ ammonium acetate and determined by atomic absorption spectrophotometry.

\section{Plant measurements}

Nine above-ground and two below-ground functional traits related to morphology, physiology and chemical composition were measured in each of the dominant species (Table 1), due to their suggested importance in the process of community assembly (Garnier et al. 2004, Shipley et al. 2006, Violle et al. 2007, Carlucci et al. 2012, Garnier and Navas 2012, Pérez-Ramos et al. 2012). In late spring 2012, during the maximum peak of plant growth, healthy adults for each of the dominant species of each site were randomly selected for measuring leaf, stem, root and whole-plant traits. All trait measurements were carried out according to the criteria defined by Cornelissen et al. (2003). For a detailed protocol of sample harvesting and trait measurements see Supplementary material Appendix 2.

\section{Above-ground functional traits}

Plant height $(\mathrm{m})$ and cover (canopy projection; $\mathrm{m}^{2}$ ) of ten individuals per species and site were measured (in total 750 individuals). Leaf and stem traits, such as specific leaf area (SLA; leaf area per unit of dry leaf mass; $\mathrm{m}^{2} \mathrm{~kg}^{-1}$ ), leaf dry matter content (LDMC; dry mass per unit of water-saturated fresh mass; $\mathrm{mg} \mathrm{g}^{-1}$ ), leaf nitrogen concentration (LNC; $\mathrm{mg} \mathrm{g}^{-1}$ ), leaf size $\left(\mathrm{cm}^{2}\right)$, leaf chlorophyll (LChl; concentration of chlorophyll per unit of fresh leaf mass; $\mu \mathrm{g} \mathrm{g}^{-1}$ ) and stem dry matter content (SDMC; dry mass per unit of water-saturated fresh mass; $\mathrm{mg}^{-1}$ ) were measured in six individuals per species and site (in total 450 individuals). For leaf measurements, a variable number (depending on the averaged leaf size of each species) of newly matured leaves were sampled in stems or twigs from the sun-exposed part of the canopy.

A mixture of the same amount of leaves from six different individuals per species and site were collected for measuring one trait directly related to water use efficiency: carbon isotopic ratio $\left(\delta^{13} \mathrm{C} ; \%\right.$, Farquhar et al. 1982$)$.

\section{Below-ground functional traits}

Roots were sampled at the individual level by excavating the first $20-30 \mathrm{~cm}$ of soil depth near the plant basal stem, ensuring thus that the sampling roots belonged to the selected individual. The roots of four individuals per species and site (in total 300 individuals) were sampled. We selected this specific soil depth based on other studies in Mediterranean woody vegetation (Silva and Rego 2004) that demonstrated that the largest fraction of fine roots appears in the first $27 \mathrm{~cm}$ of soil depth. These root samples were used to measure two belowground traits on fine roots $(<2 \mathrm{~mm}$ in diameter) related to water and nutrient uptake (Jackson et al. 1997): specific root length (SRL, root length per unit of dry root mass; $\mathrm{m} \mathrm{kg}^{-1}$ ) and root dry matter content (RDMC, root dry mass per unit of root fresh mass; $\mathrm{mg} \mathrm{g}^{-1}$ ). These data were obtained by analyzing the scanned root samples with WinRHIZO 2009 and weighing the dry root mass (for more details see Supplementary material Appendix 2).

Table 1. Mean standard deviation and range of the 11 community functional traits considered in this study. Abbreviations have also been indicated when necessary.

\begin{tabular}{|c|c|c|c|c|c|}
\hline Trait & Abbreviation & Unit & Mean & Standard deviation & Range \\
\hline \multicolumn{6}{|l|}{ Whole-plant traits } \\
\hline Plant height & & $\mathrm{m}$ & 4.30 & 2.32 & $1.92-7.81$ \\
\hline Plant cover & & $\mathrm{m}^{2}$ & 20.07 & 16.54 & $3.53-52.52$ \\
\hline \multicolumn{6}{|l|}{ Leaf traits } \\
\hline Leaf size & & $\mathrm{cm}^{2}$ & 11.51 & 12.19 & $2.72-39.66$ \\
\hline Leaf dry matter content & LDMC & $\mathrm{mg} \mathrm{g}^{-1}$ & 415.3 & 65.89 & 295.9-496.5 \\
\hline Specific leaf area & SLA & $\mathrm{m}^{2} \mathrm{~kg}^{-1}$ & 11.55 & 6.46 & $6.03-24.58$ \\
\hline Leaf nitrogen concentration & LNC & $\%$ & 2.08 & 0.53 & $1.50-3.16$ \\
\hline Leaf chlorophyll1 & LChl & $\mu \mathrm{g} \mathrm{g}^{-1}$ & 1566.2 & 782.8 & $675.9-2875.5$ \\
\hline$\delta^{13} \mathrm{C}$ & & $\%$ & -28.2 & 1.22 & $(-29.82)-(-26.34)$ \\
\hline \multicolumn{6}{|l|}{ Stem traits } \\
\hline Stem dry matter content & SDMC & $m g g^{-1}$ & 485.0 & 49.4 & $416.8-585.9$ \\
\hline \multicolumn{6}{|l|}{ Root traits } \\
\hline Root dry matter content & RDMC & $\mathrm{mg} \mathrm{g}^{-1}$ & 354.5 & 66.4 & $227.5-421.1$ \\
\hline Specific root length & SRL & $\mathrm{m} \mathrm{kg}^{-1}$ & 13.31 & 5.12 & 7.99-21.94 \\
\hline
\end{tabular}

Based on fresh mass. 


\section{Data analyses}

\section{Community weighted means}

To scale up from species to community level, all these traits (both aboveground and belowground) were weighted by the relative abundance of each species to calculate community weighted means (CWM), according to Garnier et al. (2004). The CWM traits were calculated for each site as $\sum \mathrm{P}_{\mathrm{i}} \times$ Trait $_{\mathrm{i}}$, where $P_{i}$ is the relative abundance of the species ' $I$ ' in this site, and Trait ${ }_{\mathrm{i}}$ is the average trait value obtained for the species ' $\mathrm{I}$ ' in the same site (Supplementary material Appendix 3).

\section{Relationships among environmental factors}

To understand the multidimensional relationships between the eight environmental factors considered in this study (Table 2), we conducted a principal component analysis (PCA) based on a correlation matrix of the eight variables in the nine sampling sites. The abiotic environment of each site was characterized by using averaged values of the four transects. Pearson's correlation analyses were also conducted to explore the level of dependence between these environmental variables, preceded by a Kolmogorov-Smirnov test in order to check the normality of the distribution of the studied abiotic variables. To test independence between zones and slopes, a one-way ANOVA was carried out, followed by post hoc multiple pairwise comparisons (Tukey's test) with the non-correlated variables. All these analyses were carried out using SPSS 15.0.

\section{Environmental filters as drivers of species distribution and community functional trait structure}

In order to investigate how species segregate along the studied environmental gradients, we used the redundancy analysis (RDA; implemented in the package 'vegan'; Oksanen et al. 2007). The significant relationship between species abundance and the non-correlated environmental factors (SWS, $\mathrm{pH}, \mathrm{N}, \mathrm{P}$ and $\mathrm{Mg}$ ) were tested using the permutational multivariate analysis of variance (PERMANOVA, Anderson 2001).

To determine which abiotic factors were best associated with community trait variation, we conducted maximum likelihood techniques using the likelihood package ver. 1.1 for R in R 2.10.0 statistical platform (<www.r-project.org >). From the initial eight environmental variables, we only chose for analyses a subset of five independent factors (including SWS, $\mathrm{pH}, \mathrm{N}, \mathrm{P}$ and $\mathrm{Mg}$ ), after discarding those that were significantly correlated with at least one of the selected variables (Ca, K and OM, Supplementary material Appendix 4 Table A1). We tested three alternative functions that encompass different responses of communities to abiotic factors: a linear response (linear model), an exponential response (exponential model) and a saturating response (Michaelis-Menten model). We first tested models for each environmental factor (SWS, $\mathrm{pH}, \mathrm{N}, \mathrm{P}$ and $\mathrm{Mg}$ ) and function independently, and the best of the three models was compared with the null model, which assumes no effect of any factor. Second, to test for amongfactors interactions, we fitted two-factor models using those environmental factors that had an effect on the different functional parameters when evaluated independently. We tried alternative models in which the second environmental factor was added either additively or multiplicatively. Models were parameterized with maximum likelihood (Edwards 1992), using a simulating annealing algorithm. Competing models to predict functional parameters were selected with the Akaike information criterion corrected for small sample sizes (AICc) (Burnham and Anderson 2002).

\section{Disentangling the relative importance of species turnover (species occurrence versus abundance) and intraspecific variability}

To determine the relative importance of species occurrence, abundance and intraspecific variability as mechanisms underlying changes in community functional trait structure, we used a new method (modified from Lepš et al. 2011). First, we calculated the three types of CWM parameters proposed by Lepš et al. (2011): 1) 'specific' average traits, using trait values of each species within each site, whose variation can be caused by both species turnover and intraspecific trait variability; 2) 'fixed' trait values, using mean trait values of each species along the whole environmental gradient (i.e. site-independent trait values), whose variation is only due to changes in species turnover; and 3) 'intraspecific variabilitity' trait values, which are calculated from the differences between 'specific' and 'fixed' average traits and permit an estimation of the pure effects of the intraspecific variability:

intraspecific variability parameter $=$ specific parameter fixed parameter

Second, we computed two new community parameters with the aim of disentangling the effects of the two components of species turnover (species occurrence and species abundance): 1) 'unweighted' trait values, which were calculated similarly to the above-mentioned 'fixed' trait values but without weighting them by their relative species abundances; and 2) 'species-abundance' trait values, calculated from differences between 'fixed and 'unweighted' trait values. Thus, variation in the 'unweighted' trait values is solely affected by

Table 2. Mean, standard deviation and range of the eight environmental variables quantified in the soil of the nine studied sampling sites.

\begin{tabular}{|c|c|c|c|c|c|}
\hline Variables & Abbreviation & Unit & Mean & Standard deviation & Range (min-max) \\
\hline Soil water storage & SWS & $\mathrm{I}^{-2}$ & 59.94 & 23.13 & $25.60-93.62$ \\
\hline $\mathrm{pH}$ & $\mathrm{pH}$ & & 6.86 & 0.47 & $6.25-7.83$ \\
\hline Total nitrogen & $N$ & $\%$ & 0.14 & 0.04 & $0.08-0.19$ \\
\hline Available phosphorus & $\mathrm{P}$ & $\mathrm{mg} \mathrm{kg}^{-1}$ & 4.24 & 3.89 & $1.07-12.02$ \\
\hline Available potassium & K & $\mathrm{mg} \mathrm{kg} \mathrm{kg}^{-1}$ & 145.0 & 50.13 & $71.5-228.5$ \\
\hline Available calcium & $\mathrm{Ca}$ & $\mathrm{mg} \mathrm{kg}^{-1}$ & 2677.3 & 1287.3 & $1395.5-5272.5$ \\
\hline Available magnesium & $\mathrm{Mg}$ & $\mathrm{mg} \mathrm{kg} \mathrm{kg}^{-1}$ & 347.8 & 152.7 & $193.7-519.2$ \\
\hline Organic matter & $\mathrm{OM}$ & $\%$ & 3.63 & 0.97 & $2.06-4.75$ \\
\hline
\end{tabular}


changes in species occurrence (presence/absence of species) whereas variation in 'species-abundance' trait values allows us to estimate the pure effects of changes in species abundance as follows:

species abundance parameter $=$ fixed parameter ('species turnover') - unweighted parameter ('species occurrence')

Finally, we explored 'CWM trait - environment' linkages for the two new types of community parameters ('unweighted and 'species-abundance' trait values) as well as for that used to estimate the pure effects of the intraspecific variability ('intraspecific variability' trait values). To quantify how much variability is accounted for each individual component (species occurrence, abundance and intraspecific variability), we used the method based on the sum of squares (SS) decomposition (details in Lepš et al. 2011), using the best likelihood models previously. Since the effects of the aboveexplained community parameters do not always vary independently, we also considered the effect of their covariation. In turn, covariation was partitioned into two different components, as specified in the following equations:

$\operatorname{covSS} S_{I}=S S_{\text {specific }}-S S_{\text {fixed }}-S S_{\text {intraspecific variability }}$ $\operatorname{covSS}_{\text {II }}=S S_{\text {fixed }}-S_{\text {species occurrence }}-S_{\text {species abundance }}$

where covSS $S_{I}$ is the covariation between species turnover and intraspecific variation and covSS $\mathrm{II}_{\text {II }}$ represents the covariation between species occurrence and abundance.

In summary, the maximum variability included in 'specific' average traits (i.e. that due to changes in species occurrence, abundance and intraspecific trait variability) can be defined as:

$$
\begin{aligned}
S S_{\text {specific }}= & S S_{\text {species occurrence }}+S_{\text {species abundance }} \\
& +S S_{\text {intraspecific variability }}+\operatorname{cov} S S_{I}+\operatorname{covSS}_{\text {II }}
\end{aligned}
$$

For more details see supporting information (Supplementary material Appendix 3).

Data available from the Dryad Digital Repository: $<$ http://dx.doi.org/10.5061/dryad.dr275> (de la Riva et al. 2015).

\section{Results}

\section{Environmental factors}

We detected a large variability between sites in the abiotic environment, with high differences in soil water storage (SWS) and soil nutrient concentration (Table 2, Fig. 1). No significant relationship was found between SWS and the concentration of any of the soil nutrients quantified in this study (Supplementary material Appendix 4 Table A1). Results from the PCA analysis showed a set of environmental factors related to soil fertility $(\mathrm{N}, \mathrm{K}, \mathrm{Ca}, \mathrm{Mg}$ and organic matter), which exhibited the highest scores in the first principal component (explaining the $49 \%$ of the total variance; Fig. 1). The second principal component (explaining 33\% of the variance) was mainly defined by SWS, $\mathrm{P}, \mathrm{pH}$ and $\mathrm{Ca}$ in the negative extreme of the axis (Fig. 1). No statistical differences between zones were found for any of the

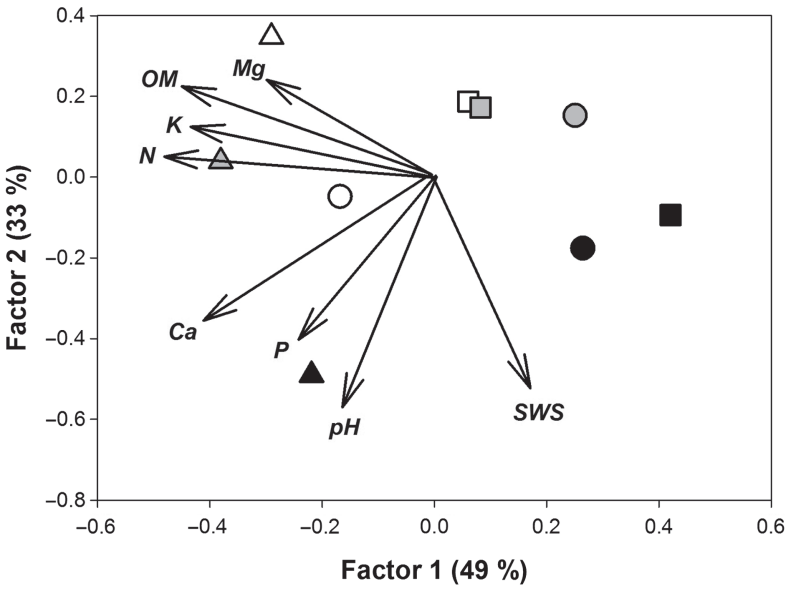

Figure 1. Ordination of the eight environmental variables considered in this study (abbreviations in Table 2) and the nine sampling sites in the space defined by the two first axes of the principal component analysis. The three study zones are separated by symbols: circles (VL), triangles (BP), and squares (LT), and the slope position by color: upper in white, medium in gray and lower in black; see complete names in Supplementary material Appendix 1.

environmental variables. However, soil water storage significantly differed as a function of the slope, with plots located in valley bottoms exhibiting higher values of SWS compared with the rest $(\mathrm{p}=0.01$; Supplementary material Appendix 4 Table A2).

\section{Environmental filters as drivers of species distribution and community functional trait structure}

Along the first RDA axis (explaining the $34 \%$ of the total variance; Fig. 2), we detected strong variations in species composition from forests dominated by deciduous tree species such as Fraxinus angustifolia, Salix atrocinerea or Ulmus minor to scrublands dominated by evergreen and

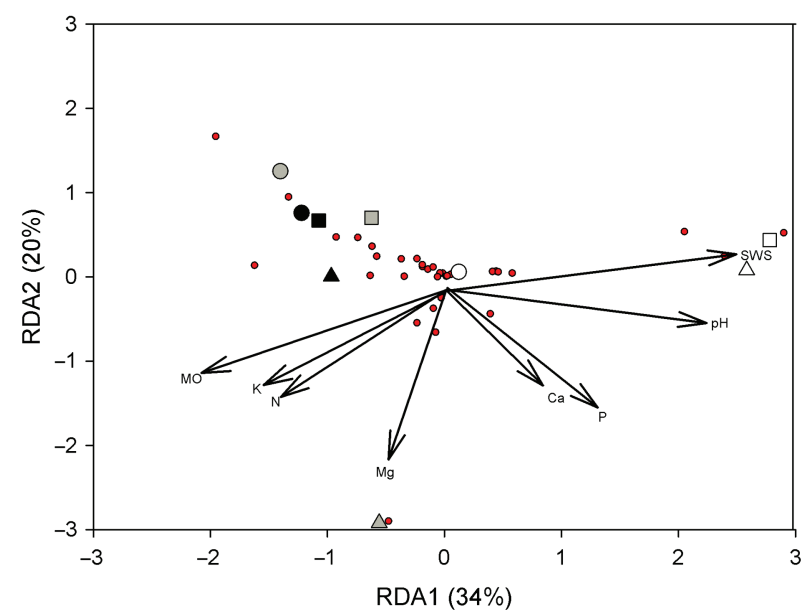

Figure 2. Ordination diagrams on the first two axes of redundancy analysis, eight environmental variables (abbreviations in Table 2), nine sites and 38 woody species. The three study zones are separated by symbols: circles (VL), triangles (BP), and squares (LT), and the slope position by color: upper in black, medium in gray and lower in white; see complete names in Supplementary material Appendix 1. 
sclerophyllous arborescent shrubs such as Arbutus unedo, Quercus ilex and Rosmarinus officinalis. Soil water storage was the only significant predictor for this floristic distribution $(\mathrm{p}<0.05$; Supplementary material Appendix 5 Table A1), as indicated by the results from the permutational multivariate analysis of variance (PERMANOVA).

Our results showed that the functional structure of the studied plant communities was highly determined by soil water storage. Thus, results from our modelling approach showed a predominant influence of soil water storage on most of the functional traits considered in this study (being selected as the best abiotic predictor for six out of the 11 analyzed traits) (Table 3). Communities growing in moister soils showed higher values of plant size (i.e. height and cover), leaf chlorophyll, specific leaf area and specific root length, all of them related to a rapid resource-uptake strategy. In contrast, drier conditions promoted the predominance of communities with higher values of $\delta^{13} \mathrm{C}$ (Table 3), reflecting a more efficient use of water under water-limited conditions. In addition, soil $\mathrm{pH}$ also played an important role in some of the functional traits considered in this study, being positively related to leaf size (Table 3). In contrast, soil nutrient availability did not have any significant role in community trait variation (Table 3 ).

When analogous CWM traits for leaves and roots were compared, we found similar trends along the range of the main environmental factors. As an example, soil water storage (SWS) influenced positively the ratio acquisition/investment for both leaves $\left(\mathrm{SLA}_{\mathrm{CWM}}\right)$ and roots $\left(\mathrm{SRL}_{\mathrm{CWM}}\right)$ of plant communities (Fig. 3).

\section{Species occurrence, abundance and intraspecific variability}

Results from partitioning the total variability in each of the functional traits considered in this study (belonging either to the aboveground or the belowground fractions) demonstrated that changes in community functional structure along environmental gradients were mainly promoted by species turnover (Fig. 4). In contrast, intraspecific variability implied very little variation in these community functional traits. Interestingly, our new method for disentangling species turnover into its quantitative and qualitative components enabled us to demonstrate that between-site trait variation was the result of changes in species occurrence rather than in the abundance of certain dominant species. The total variation was increased by a positive covariation between species turnover and intraspecific variability, as well as between species occurrence and abundance (except leaf size $_{\mathrm{CWM}}$, where the covariation II was highly negative) (Fig. 4).

\section{Discussion}

\section{Environmental drivers of community functional structure}

We found a large variation in the functional traits considered in this study along the explored environmental gradients, which suggest a non-random trait distribution at the community level (Weiher and Keddy 1999, Stubbs and Wilson 2004, Cornwell and Ackerly 2009, Freschet et al. 2011, de Bello et al. 2013). This means that only a particular set of trait values is advantageous under certain environmental conditions, thus limiting the range of trait space that species and communities are able to occupy (Díaz et al. 1998, Holdaway and Sparrow 2006, Cornwell and Ackerly 2009, de la Riva et al. 2011).

Our results showed that community functional traits were mainly driven by soil water storage. In contrast, soil nutrient availability did not (apparently) exert any significant

Table 3. Summary of the best-fitted models analyzing trait values (at the community level) in response to soil factors. The best-supported models $(\triangle \mathrm{AIC} \leq 2)$ have been highlighted with bold letters. See Table 1 and 2 for abbreviations of traits and soil factors. FF: form of function (LIN: linear function).

\begin{tabular}{|c|c|c|c|c|c|c|c|}
\hline & Dependent variable & Soil factors & $\mathrm{FF}$ & Relation & $\mathrm{R}^{2}$ & $\mathrm{AIC}$ & $\Delta \mathrm{AIC}$ \\
\hline \multirow[t]{4}{*}{ Whole-plant traits } & Plant height & SWS & LIN & + & 0.75 & 37.96 & 0.00 \\
\hline & & & null & & & 45.61 & 7.65 \\
\hline & Plant cover & SWS & LIN & + & 0.60 & 77.44 & 0.00 \\
\hline & & & null & & & 80.99 & 3.55 \\
\hline \multirow[t]{14}{*}{ Leaf traits } & Leaf size & $\mathrm{pH}$ & LIN & + & 0.61 & 71.81 & 0.00 \\
\hline & & SWS & LIN & + & 0.56 & 72.87 & 1.06 \\
\hline & & & null & & & 75.50 & 3.69 \\
\hline & LDMC & & null & & & 22.58 & 0.00 \\
\hline & SLA & SWS & LIN & + & 0.70 & 57.90 & 0.00 \\
\hline & & $\mathrm{pH}$ & LIN & + & 0.54 & 61.92 & 4.02 \\
\hline & & & null & & & 64.06 & 6.16 \\
\hline & LNC & & null & & & 24.79 & 0.00 \\
\hline & LChl & SWS & LIN & + & 0.71 & 143.86 & 0.00 \\
\hline & & & null & & & 150.15 & 6.30 \\
\hline & $\delta^{13} \mathrm{C}$ & SWS & LIN & - & 0.71 & 30.76 & 0.00 \\
\hline & & $\mathrm{pH}$ & LIN & - & 0.13 & 37.66 & 6.89 \\
\hline & & $\mathrm{P}$ & LIN & - & 0.11 & 37.90 & 7.14 \\
\hline & & & null & & & 91.66 & 60.90 \\
\hline Stem traits & SDMC & & null & & & 22.56 & 0.00 \\
\hline \multirow[t]{3}{*}{ Root traits } & RDMC & & null & & & 106.00 & 0.00 \\
\hline & SRL & SWS & LIN & + & 0.53 & 57.90 & 0.00 \\
\hline & & & null & & & 59.89 & 2.00 \\
\hline
\end{tabular}




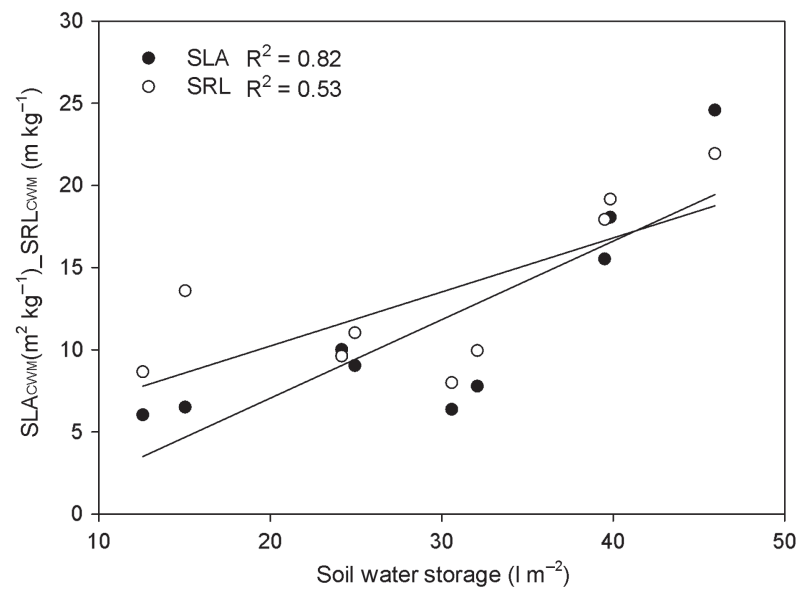

Figure 3. Relationships between analogous leaf and root community functional traits and the best-supported environmental predictor (SWS, soil water storage). The value of $\mathrm{R}^{2}$ has been also indicated. See Table 1 for trait abbreviations.

role or this was secondary compared with that of water. These results are in accordance with a previous study with Mediterranean woody plant species (Cornwell and Ackerly 2009), but contrast with others where soil nutrients played a predominant role as drivers of changes in community functional structure (Ordońez et al. 2009, Fyllas et al. 2009, Pérez-Ramos et al. 2012). These controversial results suggest that the relative importance of both types of soil resources for plant community assembly is likely to be influenced by several factors, including the ecosystem type, the range of variation of the explored environmental gradients, the scale of the studied system (landscape versus local) or the selected set of functional traits considered in the study.

Soil water availability mainly shaped the functional trait structure of the studied plant communities according to the widely known tradeoff between resource acquisition and

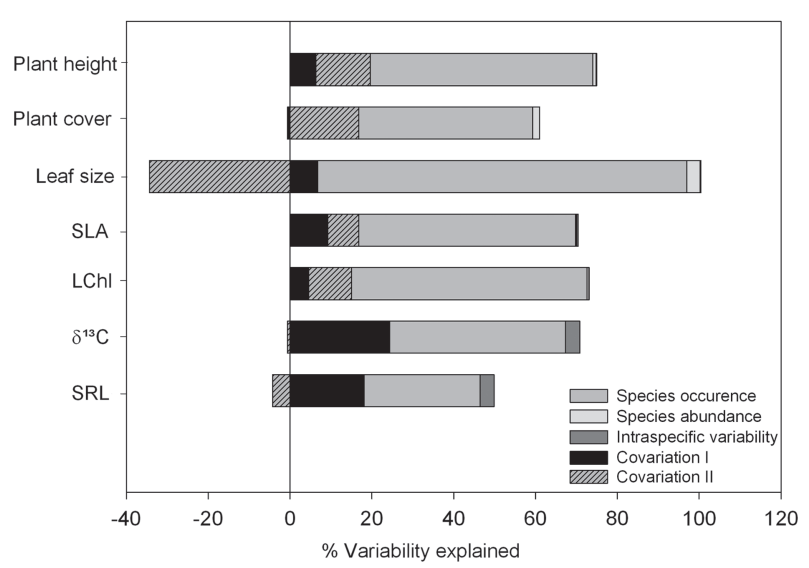

Figure 4. Partitioning of the total variability in the studied community functional traits along the best-supported environmental variables (Table 3 ). When the sum of the amount of variability explained by turnover and intraspecific variability effects is lower than that explained by the total variability of the community, covariation I reaches negative values. Similarly, negative values of covariation II appear when the sum of species occurrence and abundance effects is lower than that of species turnover. Functional traits have been abbreviated as indicated in Table 1 . conservation (Chapin et al. 1993, Grime 2001, Wright et al. 2004). Interestingly, both the aboveground and the belowground traits considered in this study showed a similar trend along the gradient of soil water storage, suggesting that a filtering process is operating for an integrated resourceuptake strategy at the community level (concept of plant community economics spectrum, sensu Pérez-Ramos et al. 2012). Communities growing in wetter sites exhibited higher values of SLA and SRL, which could potentially confer them with an advantage in resource-uptake efficiency by increasing the absorption surface per unit of tissue biomass (Reich et al. 1992, Ryser 1998). However, communities with higher values of SLA and SRL may be more vulnerable to drought conditions (Fitter 1987, Reich et al. 1991, 1998, Pérez-Ramos et al. 2013). Thus, water limitation could act as an abiotic filter, excluding or reducing the dominance of fast-growing species which are usually less tolerant to these more stressed conditions (Lopez-Iglesias et al. 2014).

In contrast, water shortage promoted the prevalence of communities with higher water-use efficiency (i.e. high values of $\delta^{13} \mathrm{C}$ ), which is commonly associated with a conservative water use strategy at the expense of slower plant growth (Farquhar et al. 1982, Domínguez et al. 2012). These slower-growth, drought-tolerant and more conservative species were probably excluded from wetter sites by a strong aboveground competition for space and light in the dense shade created by the tall trees and shrubs typical of these more productive sites.

\section{Disentangling the relative importance of species occurrence, abundance and intraspecific variability}

Our results from analyses of variance decomposition showed that variations in community functional traits along environmental gradients were mainly explained by changes in species turnover rather than being due to a strong intraspecific variability. Previous studies found similar patterns, though in general with higher values of intraspecific variability (Albert et al. 2010b, Jung 2010, de Bello et al. 2011, Pérez-Ramos et al. 2012, Jung et al. 2014). In this study, the proportion of variance explained by intraspecific variability was very low (below 5\%), in accordance with other Mediterranean studies focusing on aboveground traits (Roche et al. 2004, Cornwell and Ackerly 2009), which support the general agreement that trait variation is much greater among species than therein (Garnier et al. 2001). The low proportion of variance explained by intraspecific variability is also reflected in the low number of species that coincided in the different sampling sites (only 17 of 38 species appeared in more than one site), which reveals the predominance of a process of species replacement along the environmental gradient. In our study area, plant communities inhabiting water-limited habitats were predominantly composed of drought-tolerant evergreen species (i.e. Arbutus unedo, Quercus ilex, Rosmarinus officinalis), whereas plant communities growing in moister sites were dominated by deciduous species (i.e. Alnus glutinosa, Fraxinus angustifolia, Salix atrocinerea and Ulmus minor). Our results supports previous studies with Mediterranean woody plant communities (Cornwell and Ackerly 2009), but contrast with others that detected a strong relative importance of intraspecific variability as driver of changes in SLA (Jung 
et al. 2010, Auger and Shipley 2013, Kichenin et al. 2013). These contrasting results suggest that the relative contribution of intraspecific versus interspecific variability can differ largely among different spatial scales, species, traits and habitats of study (Albert et al. 2011, Auger and Shipley 2013, Carlucci et al. 2015).

Results from our method of total variability decomposition in three individual components (species occurrence, abundance and intraspecific variability) are novel for different reasons. First, to our knowledge, this is the first study that quantifies the relative importance of the two main sources of variability (species turnover vs. intraspecific variability) in belowground traits, particularly in woody plant species. Most previous studies have focused on aboveground traits (particularly leaves), whereas the variability included in those pertaining to the belowground component has remained largely unexplored. In this study, we have provided some light on this subject, showing that roots followed a similar pattern to leaves, with a lower percentage of variance explained by intraspecific variability (below 4\%) compared to that of species turnover. Further studies in other plant communities and systems are therefore necessary to discern whether these trends for the belowground fraction are consistent at a wider spatial scale.

Second, we have proposed a new method for disentangling the relative importance of species occurrence and abundance as components of species turnover, which could be potentially applied for answering different ecological questions. Using this new approach, we observed that variation in community functional structure along environmental gradients was not determined by changes in species abundance (with a percentage of explained variance below $5 \%$ for all the traits considered in this study) but by shifts in species occurrence. The higher relative importance of species occurrence suggests that the assembly mechanisms of these Mediterranean woody plant communities are the result of a process of habitat filtering which prevents the establishment of species with less suitable trait values for coping with environmental constraints (in our case water shortage). In contrast, in wetter soils, communities are predominantly dominated by acquisitive fast-growing species, which outcompete those associated with a more conservative strategy (Chesson 2000, Suding et al. 2005, Cornwell et al. 2006, Mayfield and Levine 2010, Weiher et al. 2011, Gross et al. 2013). Therefore, changes in climate conditions, such as the increased aridity predicted by climate change models (IPCC 2001), could cause a strong alteration in species composition of these communities (promoting the disappearance of species with acquisitive strategies) since abiotic filters act primarily on species occurrence rather than modifying their respective abundance values. The decomposition method of interspecific trait variation into its qualitative and quantitative components could be used as a valuable tool for a better understanding of community responses to environmental gradients due to changes in species occurrence and/or abundance (Ackerly and Cornwell 2007, Sandel et al. 2010). This approach could be also applied to a broad number of ecological contexts, such as those derived from global change predictions (McGill et al. 2006), which could allow gaining valuable insights into the relative importance of the different components of species turnover as drivers of the process of community assembly under changing environments.

\section{Conclusions}

In this study, we tried to discern the assemblage patterns of Mediterranean woody plant communities along natural environmental gradients, using a whole-level, trait-based approach. We found that soil water availability was the main abiotic driver of community functional structure, water-limited conditions promoting the predominance of specific trait values (both in above and belowground fractions) associated to a resource-acquisition or conservation strategy. Interestingly, the new method of variance decomposition that we proposed in this study enabled us to demonstrate that community functional structure was mainly promoted by a process of species replacement, while changes in species abundance and intraspecific variability were of lower importance for community assembly in these Mediterranean ecosystems. These findings represent a crucial step towards a more general understanding of the relative importance of intraspecific versus interspecific trait variation in plant communities, with strong implications for understanding the rules and mechanisms governing the process of community assembly along environmental gradients. Although our approach does not allow us to entirely disentangle the underlying mechanisms that drive the process of community assembly, it does provide a set of exciting hypotheses to be further investigated not only in Mediterranean but in other plant communities world-wide.

Acknowledgements - This study was funded by the Spanish MEC coordinated project DIVERBOS (CGL2011-30285-C02-01 and C02-02), the Andalusian ANASINQUE project (PGC2010RNM-5782), and European FEDER funds. Isotopic analysis was carried out in the LIE of EBD, CSIC, multielemental analysis of soil and plant samples in the IRNAS Analysis Service and N and C of leaves in the SCAI of University of Córdoba.

\section{References}

Ackerly, D. D. et al. 2002. Leaf size, specific leaf area and microhabitat distribution of chaparral woody plants: contrasting patterns in species level and community level analyses. - Oecologia 130: 449-457.

Ackerly, D. D. and Cornwell, W. K. 2007. A trait-based approach to community assembly: partitioning of species trait values into within- and among-community components. - Ecol. Lett. 10: 135-145.

Albert, C. H. et al. 2010a. A multi-trait a pproach reveals the structure and the relative importance of intra- vs interspecific variability in plant traits. - Funct. Ecol. 24: 1192-1201.

Albert, C. H. et al. 2010b. Intraspecific functional variability: extent, structure and sources of variation. - J. Ecol. 98: 604-613.

Albert, C. H. et al. 2011. When and how should intraspecific variability be considered in trait-based plant ecology? - Persp. Plant Ecol. Evol. Syst. 13: 217-225.

Anderson, M. J. 2001. A new method for non-parametric multivariate analysis of variance. - Aust. Ecol. 26: 32-46. 
Auger, S. and Shipley, B. 2013. Inter-specific and intra-specific trait variation along short environmental gradients in an old-growth temperate forest. - J. Veg. Sci. 24: 419-428.

Baraloto, C. et al. 2010. Decoupled leaf and stem economics in rain forest trees. - Ecol. Lett. 13: 1338-1347.

Bernard-Verdier, M. et al. 2012. Community assembly along a soil depth gradient: contrasting patterns of plant trait convergence and divergence in a Mediterranean rangeland. - J. Ecol. 100: 1422-1433.

Burnham, K. P. and Anderson, D. R. 2002. Model selection and multimodel inference: a practical information-theoretic approach, 2nd edn. - Springer.

Carlucci, M. B. et al. 2012. Individual-based trait analyses reveal assembly patterns in tree sapling communities. - J. Veg. Sci. 23: $176-186$.

Carlucci, M. B. et al. 2015. Between-and within-species trait variability and the assembly of sapling communities in forest patches. - J. Veg. Sci. 26: 21-31.

Chapin, F. S. III et al. 1993. Evolution of suites of traits in response to environmental stress. - Am. Nat. 142: 78-92.

Chesson, P. 2000. Mechanisms of maintenance of species diversity. - Annu. Rev. Ecol. Syst. 31: 343-366.

Cingolani, A. M. et al. 2007. Filtering processes in the assembly of plant communities: are species presence and abundance driven by the same traits? - J. Veg. Sci. 18: 911-920.

Cleland, E. E. et al. 2011. Patterns of trait convergence and divergence among native and exotic species in herbaceous plant communities are not modified by nitrogen enrichment. - J. Ecol. 99: 1327-1338.

Cornelissen, J. H. C. et al. 2003. A handbook of protocols for standardised and easy measurement of plant functional traits worldwide. - Aust J. Bot. 51: 335-380.

Cornwell, W. K. and Ackerly, D. D. 2009. Community assembly and shifts in plant trait distributions across an environmental gradient in coastal California. - Ecol. Monogr. 79: 109-126.

Cornwell, W. K. et al. 2006. A trait-based test for habitat filtering: convex hull volume. - Ecology 100: 1465-1471.

de Bello, F. et al. 2011. Quantifying the relevance of intraspecific trait variability for functional diversity. - Meth. Ecol. Evol. 2: 163-174.

de Bello, F. et al. 2013. Hierarchical effects of environmental filters on the functional structure of plant communities: a case study in the French Alps. - Ecography 36: 393-402.

de la Riva, E. G. et al. 2011. Rates of local colonization and extinction reveal different plant community assembly mechanisms on road verges in central Spain. - J. Veg. Sci. 22: 292-302.

de la Riva, E. G. et al. 2015. Data from: Disentangling the relative importance of species occurrence, abundance and intraspecific variability in community assembly: a trait-based approach at the whole-plant level in Mediterranean forests. - Dryad Digital Repository, < http://dx.doi.org/10.5061/dryad.dr275>.

Diamond, J. M. 1975. Assembly of species communities. - In: Cody, M. L. and Diamond, J. M. (eds), Ecology and evolution of communities. Belknap press, pp. 342-444.

Díaz, S. et al. 1998. Plant functional traits and environmental filters at a regional scale. - J. Veg. Sci. 9: 113-122.

Domínguez, M. T. et al. 2012. Relationships between leaf morphological traits, nutrient concentrations and isotopic signatures for Mediterranean woody plant species and communities. Plant Soil 357: 407-424.

Edwards, A. W. F. 1992. Likelihood, expanded edition. - Johns Hopkins Univ. Press.

Farquhar, G. D. et al. 1982. On the relationship between carbon isotope discrimination and the intercellular carbon dioxide concentration in leaves. - Aust. J. Plant Physiol. 9: 121-137.

Fitter, A. H. 1987. An architectural approach to the comparative ecology of plant root systems. - New Phytol. 106: 61-77.
Freschet, G. T. et al. 2011. Global to community scale differences in the prevalence of convergent over divergent leaf trait distributions in plant assemblages. - Global Ecol. Biogeogr 20: 755-765.

Fyllas, N. et al. 2009. Basin-wide variations in foliar properties of Amazonian forest: phylogeny, soils and climate. - Biogeosciences 6: 2677-2708.

Garnier, E. and Navas, M. L. 2012. A trait-based approach to comparative functional plant ecology: concepts, methods and applications for agroecology. - Agron. Sustain. Dev. 32: 365-399.

Garnier, E. et al. 2001. Consistency of species ranking based on functional leaf traits. - New Phytol. 152: 69-83.

Garnier, E. et al. 2004. Plant functional markers capture ecosystem properties. - Ecology 85: 2630-2637.

Grime, J. P. 2001. Plant strategies, vegetation processes and ecosystem properties. -Wiley.

Gross, N. et al. 2009. Linking individual response to biotic interactions with community structure: a trait-based framework. - Funct. Ecol. 23: 1167-1178.

Gross, N. et al. 2013. Uncovering multiscale effects of aridity and biotic interactions on the functional structure of Mediterranean shrublands. - J. Ecol. 101: 637-649.

Holdaway, R. J. and Sparrow, A. D. 2006. Assembly rules operating along a primary riverbed-grassland successional sequence. J. Ecol. 94: 1092-1102.

Holdaway, R. J. et al. 2011. Species- and community-level changes in fine root traits along a 120000 year soil chronosequence in New Zealand. - J. Ecol. 99: 954-963.

IPCC 2001. Climate change 2001: the scientific basis. Contrib. Working Grp I 3rd Assess. Rep. of the Intergovernmental panel on climate change. - Cambridge Univ. Press.

Jackson, R. B. et al. 1997. A global budget for fine root biomass, surface area and nutrient contents. - Proc. Natl Acad. Sci. USA 94: 7362-7366.

Jobbágy, E. G. and Jackson, R. B. 2001. The distribution of soil nutrients with depth: global patterns and the imprint of plants. - Biogeochemistry 53: 51-77.

Jung, V. 2010. Intraspecific variability and trait-based community assembly. - J. Ecol. 98: 1134-1140.

Jung, V. et al. 2014. Intraspecific trait variability mediates the response of subalpine grassland communities to extreme drought events. - J. Ecol. 102: 45-53.

Keddy, P. A. 1992 Assembly and response rules: two goals for predictive community ecology. - J. Veg. Sci. 3: 157-164.

Kichenin, E. et al. 2013. Contrasting effects of plant inter and intraspecific variation on community level trait measures along an environmental gradient. - Funct. Ecol. 27: 1254-1261.

Laliberté, E. et al. 2012. Which plant traits determine abundance under long-term shifts in soil resource availability and grazing intensity? - J. Ecol. 100: 662-677.

Lepš, J. et al. 2011. Community trait response to environment: disentangling species turnover vs intraspecific trait variability effects. - Ecography 34: 856-863.

López-Iglesias, B. et al. 2014. Functional traits predict drought performance and distribution of Mediterranean woody species. - Acta Oecol. 56: 10-18.

MacArthur, R. and Levins, R. 1967. The limiting similarity, convergence and divergence of coexisting species. - Am. Nat. 101: 377-385.

Mayfield, M. M. and Levine, J. M. 2010. Opposing effects of competitive exclusion on the phylogenetic structure of communities. - Ecol. Lett. 13: 1085-1093.

McCormack, L. et al. 2012. Predicting fine root lifespan from plant functional traits in temperate trees. - New Phytol. 195: 823-831.

McGill, B. J. et al. 2006. Rebuilding community ecology from functional traits. - Trends Ecol. Evol. 21: 178-185. 
Oksanen, J. et al. 2007. - The vegan package. - R community ecology package.

Ordoñez, J. C. et al. 2009. A global study of relationships between leaf traits, climate and soil measures of nutrient fertility. Global Ecol. Biogeogr. 18: 137-149.

Pérez-Ramos, I. M. et al. 2012. Evidence for a "plant community economics spectrum" driven by nutrient and water limitations in a Mediterranean rangeland of southern France. - J. Ecol. 100: 1315-1327.

Pérez-Ramos, I. M. et al. 2013. Tradeoffs between functional strategies for resource-use and drought-survival in Mediterranean rangeland species. - Environ. Exp. Bot. 100: 126-136.

Reich, B. et al. 1991. Leaf lifespan as a determinant of leaf structure and function among 23 amazonian tree species. - Oecologia 86: 16-24.

Reich, P. B. et al. 1992. Leaf life-span in relation to leaf, plant and stand characteristics among diverse. - Ecol. Monogr. 62: 365-392.

Reich, P. B. et al. 1998. Photosynthesis and respiration rates depend on leaf and root morphology and nitrogen concentration in nine boreal tree species differing in relative growth rate. - Funct. Ecol. 12: 395-405.

Roche, P. et al. 2004. Congruency analysis of species ranking based on leaf traits: which traits are the more reliable? - Plant Ecol. 174: 37-48.

Ryser, P. 1998. Intra- and interspecific variation in root length, root turnover and the underlying parameters. - In: Lambers, H. et al. (eds), Variation in plant growth. Backhuys Publishers, pp. 441-465.

Sandel, B. et al. 2010. Contrasting trait responses in plant communities to experimental and geographic variation in precipitation. - New Phytol. 188: 565-75.

Shipley, B. et al. 2006. From plant traits to plant communities: a statistical mechanistic approach to biodiversity. - Science 314: 812-814.

Supplementary material (available online as Appendix oik01875 at <www.oikosjournal.org/appendix/oik-01875>). Appendix 1-5.
Shipley, B. 2010. From plant traits to vegetation structure: chance and selection in the assembly of ecological communities. - Cambridge Univ. Press.

Siefert, A. 2012. Incorporating intraspecific variation in tests of trait-based community assembly. - Oecologia 170: 767-775.

Silva, J. S. and Rego, F. C. 2003. Root distribution of a Mediterranean shrubland in Portugal. - Plant Soil 255: 529-540.

Silva, J. S. and Rego, F. C. 2004 . Root to shoot relationships in Mediterranean woody plants from central Portugal. - Biologia 59: 1-7.

Sparks, D. L. 1996. Methods of soil analysis. Part 3. Chemical method. - Soil Sci. Soc. Am. Book Series 5, Madison, WI.

Spasojevic, M. J. and Suding, K. N. 2012. Inferring community assembly mechanisms from functional diversity patterns: the importance of multiple assembly processes. - J. Ecol. 100: 652-661.

Stubbs, W. J. and Wilson, J. B. 2004. Evidence for limiting similarity in a sand dune community. - J. Ecol. 92: 557-567.

Suding, K. N. et al. 2005. Functional- and abundance-based mechanisms explain diversity loss due to $\mathrm{N}$ fertilization. - Proc. Natl Acad. Sci. USA 102: 4387-4392.

Terradas, J. 2001. Ecología de la Vegetación. De la Ecofisiología de las Plantas a la Dinámica de Comunidades y Paisajes. - Omega, Barcelona.

Violle, C. et al. 2007. Let the concept of trait be functional! Oikos 116: 882-892.

Weiher, E. and Keddy, P. 1999. Ecological assembly rules: perspectives, advances, retreats. - Cambridge Univ. Press.

Weiher, E. et al. 2011. Advances, challenges and a developing synthesis of ecological community assembly theory. - Phil. Trans. R. Soc. B 366: 2403-2413.

Wright, I. J. et al. 2004. The worldwide leaf economics spectrum. - Nature 428: 821-827. 


\section{Appendix 1:}

Table A1. Localization and description of the three study zones and the nine sampling sites.

\begin{tabular}{|c|c|c|c|c|c|}
\hline Zone & Plot & Latitude & Longitude & $\begin{array}{c}\text { Altitude } \\
\text { (m.a.s.l.) }\end{array}$ & Dominant vegetation \\
\hline \multirow{3}{*}{$\begin{array}{l}\text { Virgen de Linares } \\
\qquad(\mathrm{VL})\end{array}$} & Upper & $37^{\circ} 56^{\prime} 95^{\prime \prime} \mathrm{N}$ & $4^{\circ} 46^{\prime} 22^{\prime \prime} \mathrm{W}$ & 253 & Evergreen oak (Quercus coccifera) mixed with shrub species. \\
\hline & Medium & $37^{\circ} 55^{\prime} 83^{\prime \prime} \mathrm{N}$ & $4^{\circ} 46^{\prime} 93^{\prime \prime} \mathrm{W}$ & 217 & Evergreen oak (Quercus ilex) mixed with shrub species. \\
\hline & Lower & $37^{\circ} 55^{\prime} 73^{\prime \prime} \mathrm{N}$ & $4^{\circ} 46^{\prime} 16^{\prime \prime} \mathrm{W}$ & 176 & $\begin{array}{l}\text { Deciduous species (Celtis australis and Ulmus minor) mixed } \\
\text { with riparian species. }\end{array}$ \\
\hline \multirow{3}{*}{$\begin{array}{l}\text { Baños de Popea } \\
\text { (BP) }\end{array}$} & Upper & $37^{\circ} 56^{\prime} 81^{\prime \prime} \mathrm{N}$ & $4^{\circ} 53^{\prime} 44^{\prime \prime} \mathrm{W}$ & 329 & Evergreen oak (Quercus coccifera) mixed with shrub species. \\
\hline & Medium & $37^{\circ} 56^{\prime} 64^{\prime \prime} \mathrm{N}$ & $4^{\circ} 53^{\prime} 62^{\prime \prime} \mathrm{W}$ & 312 & Deciduous oak (Quercus faginea) mixed with shrub species. \\
\hline & Lower & $37^{\circ} 56^{\prime} 90^{\prime \prime} \mathrm{N}$ & $4^{\circ} 53^{\prime} 60^{\prime \prime} \mathrm{W}$ & 281 & $\begin{array}{l}\text { Deciduous species (Alnus glutinosa, Fraxinus angustifolia) } \\
\text { mixed with riparian species }\end{array}$ \\
\hline \multirow{3}{*}{$\begin{array}{l}\text { Las Tonadas } \\
\quad(\mathrm{LT})\end{array}$} & Upper & $38^{\circ} 1^{\prime} 32^{\prime \prime} \mathrm{N}$ & $5^{\circ} 1^{\prime} 65^{\prime \prime} \mathrm{W}$ & 550 & $\begin{array}{l}\text { Evergreen oaks (Quercus coccifera and Quercus ilex) mixed } \\
\text { with Arbutus unedo and shrubs species. }\end{array}$ \\
\hline & Medium & $38^{\circ} 1^{\prime} 09^{\prime \prime} \mathrm{N}$ & $5^{\circ} 1^{\prime} 57^{\prime \prime} \mathrm{W}$ & 510 & $\begin{array}{l}\text { Evergreen oak (Quercus ilex) mixed with deciduous species } \\
\text { (Pyrus bourgaeana) and shrub species. }\end{array}$ \\
\hline & Lower & $38^{\circ} 1^{\prime} 73^{\prime \prime} \mathrm{N}$ & $5^{\circ} 1^{\prime} 54^{\prime \prime} \mathrm{W}$ & 499 & $\begin{array}{l}\text { Deciduous species (Alnus glutinosa, Fraxinus angustifolia) } \\
\text { mixed with riparian vegetation }\end{array}$ \\
\hline
\end{tabular}


Table A2. Species studied and the plant abundance ( $\%$ of lineal cover) in the

different sampling sites.

\begin{tabular}{|c|c|c|c|c|c|c|c|c|c|c|c|c|}
\hline \multirow{2}{*}{ Species } & \multirow{2}{*}{ Family } & \multirow{2}{*}{ Life habit } & \multirow{2}{*}{ Leaf habit } & \multicolumn{3}{|c|}{ Virgen de Linares } & \multicolumn{3}{|c|}{ Baños de Popea } & \multicolumn{3}{|c|}{ Las Tonadas } \\
\hline & & & & Upper & Medium & Lower & Upper & Medium & Lower & Upper & Medium & Lower \\
\hline Alnus glutinosa & Betulaceae & Tree & Winter deciduous & - & - & - & - & - & 27.23 & - & - & 12.65 \\
\hline Arbutus unedo & Ericaceae & Arborescent shrub & Evergreen & - & - & - & 5.25 & - & - & 19.63 & 3.62 & - \\
\hline Celtis australis & Cannabaceae & Tree & Winter deciduous & - & - & 18.34 & - & - & - & - & - & - \\
\hline Cistus albidus & Cistaceae & Shrub & Evergreen & 19.16 & 2.58 & - & 2.83 & - & - & 4.88 & - & - \\
\hline Cistus crispus & Cistaceae & Shrub & Evergreen & 7.35 & - & - & & - & - & - & - & - \\
\hline Cistus ladanifer & Cistaceae & Shrub & Evergreen & 4.29 & - & - & 10.49 & - & - & 10.8 & - & - \\
\hline Cistus monspeliensis & Cistaceae & Shrub & Evergreen & - & - & - & - & - & - & - & 2.8 & - \\
\hline Cistus salvifolius & Cistaceae & Shrub & Evergreen & - & 7.74 & - & & - & - & - & - & - \\
\hline Crataegus monogyna & Rosaceae & Arborescent shrub & Winter deciduous & - & - & 5.27 & - & - & - & - & - & - \\
\hline Cydonia oblonga & Rosaceae & Tree & Winter deciduous & - & - & - & - & - & - & - & 2.25 & - \\
\hline Ficus carica & Moraceae & Tree & Winter deciduous & - & - & - & - & - & 10.12 & - & - & - \\
\hline Fraxinus angustifolia & Oleaceae & Tree & Winter deciduous & - & - & - & - & - & 30.6 & - & - & 37.96 \\
\hline Genista hirsuta & Fabaceae & Shrub & Summer deciduous & 5.92 & 4.78 & - & 13.27 & - & - & 15.15 & - & - \\
\hline Jasminum fruticans & Oleaceae & Shrub & Evergreen & - & - & - & - & 7.02 & - & - & - & - \\
\hline Lavandula stoechas & Lamiaceae & Shrub & Evergreen & 4.32 & 2.58 & - & - & - & - & - & - & - \\
\hline Myrtus communis & Mirtaceae & Shrub & Evergreen & - & 6.89 & - & - & 2.72 & - & 4.48 & - & - \\
\hline Nerium oleander & Apocynaceae & Arborescent shrub & Evergreen & - & - & 11.71 & - & 5.22 & 7.21 & - & - & - \\
\hline Phlomis purpurea & Lamiaceae & Shrub & Evergreen & 5.56 & - & - & - & - & - & - & - & - \\
\hline Phillyrea angustifolia & Oleaceae & Arborescent shrub & Evergreen & - & - & - & 4.62 & - & - & 9.1 & 4.36 & - \\
\hline Phillyrea latifolia & Oleaceae & Arborescent shrub & Evergreen & - & - & - & - & 45.05 & - & - & - & - \\
\hline Pistacia lentiscus & Anacardiaceae & Arborescent shrub & Evergreen & 10.02 & 33.61 & 17.63 & - & 2.99 & - & - & 5.65 & - \\
\hline Pistacia terebinthus & Anacardiaceae & Arborescent shrub & Winter deciduous & - & - & - & - & 2.54 & - & - & - & - \\
\hline Populus alba & Salicaceae & Tree & Winter deciduous & - & - & - & - & - & - & - & - & 6.68 \\
\hline Pyrus bourgaeana & Rosaceae & Tree & Winter deciduous & - & - & - & - & - & - & - & 7.22 & - \\
\hline Quercus coccifera & Fagaceae & Arborescent shrub & Evergreen & 19.71 & 7.74 & - & 23.5 & 7.37 & - & 9.29 & 7.96 & - \\
\hline Quercus faginea & Fagaceae & Tree & Winter deciduous & - & - & - & - & 2.65 & - & - & - & - \\
\hline Quercus ilex & Fabaceae & Tree & Evergreen & 18.06 & 25.32 & - & - & - & - & 16.33 & 25.24 & - \\
\hline Rhamnus lycioides & Rhamnaceae & Shrub & Evergreen & - & - & 5.64 & - & - & - & - & - & - \\
\hline Rosa canina & Rosaceae & Shrub & Winter deciduous & - & - & - & - & - & - & - & 2.55 & - \\
\hline Rosmarinus officinalis & Lamiaceae & Shrub & Evergreen & - & - & - & 31.06 & - & - & - & - & - \\
\hline Rubus ulmifolius & Rosaceae & Shrub & Evergreen & - & - & 11.89 & - & - & 8.71 & - & 13.44 & 25.65 \\
\hline Ruscus aculeatus & Asparagaceae & Shrub & Evergreen & - & - & - & - & 4.57 & - & - & 3.44 & - \\
\hline Salix atrocinerea & Salicaceae & Tree & Winter deciduous & - & - & - & - & & - & - & - & 6.21 \\
\hline Smilax aspera & Smilacaceae & Vine & Evergreen & - & - & - & - & 2.61 & - & - & - & - \\
\hline Teucrium fruticans & Lamiaceae & Shrub & Evergreen & - & - & - & 2.89 & - & - & - & - & - \\
\hline Ulmus minor & Ulmaceae & Tree & Winter deciduous & - & - & 17.21 & - & - & 7.13 & - & - & - \\
\hline Viburnum tinus & Adoxaceae & Arborescent shrub & Evergreen & - & - & - & - & 7.75 & - & - & 11.37 & - \\
\hline Vitis vinifera & Vitaceae & Vine & Winter deciduous & - & - & 7.62 & - & - & - & - & - & - \\
\hline
\end{tabular}


Table A3. Climatological information for the three zones. Data were obtained from Global-PET Database and Worldclim.

\begin{tabular}{|c|c|c|c|c|c|c|c|}
\hline Zone & $\operatorname{EVTP}\left(\mathrm{I} / \mathrm{m}^{2}\right)$ & AAT (으) & $\operatorname{AAP}(\mathrm{mm})$ & DTR (으) & AWT (으) & $\mathrm{ACT}(\stackrel{\circ}{\circ})$ & SP \\
\hline Las Tonadas & 1296 & 15.5 & 668 & 12.4 & 34.8 & 2.1 & 57 \\
\hline Baños de Popea & 1324 & 16.3 & 647 & 12.3 & 35.5 & 3 & 58 \\
\hline Virgen de Linares & 1338 & 16.5 & 638 & 12.2 & 35.5 & 3.2 & 59 \\
\hline
\end{tabular}


Appendix 2 Measurements of plant functional traits.

Nine above-ground and two below-ground functional traits related to morphology, physiology and chemical composition were measured. These traits, at leaf, stem, root and whole plant level (Table 1) are related to the ability to acquire, transport and fulfill plant water and nutrient requirements.

Plant height and cover were measured in ten individuals, per species and site, with a tape except for the taller species, whose height was estimated with the 'Christen height meter based on trigonometric principles (Klein 2007). Plant cover area was estimated by ellipse area equation (major and minor diameter of the canopy projection).

For leaf and stem measurements, six individuals per species and site were chosen. A few branches with young, fully expanded leaves and a portion of stem of the previous year were collected from each individual plant. These branches were stored in plastic bags to prevent water loss and further transported to the laboratory, where they were maintained with the basal portion of the stem submerged in water at $10^{\circ} \mathrm{C}$ for $24 \mathrm{~h}$ in darkness to allow a complete re-hydration.

A subsample of leaves was removed from the stem, the petiole was excised and the leaves were fresh-weighted and scanned. The leaf area was calculated using image analysis software (Image-Pro 4.5, Media Cybernetic Inc. USA). Leaves were oven-dried for at least $48 \mathrm{~h}$ at $60^{\circ} \mathrm{C}$, and further weighed with a precision of $0.001 \mathrm{~g}$. Specific Leaf Area (SLA, $\mathrm{m}^{2} \mathrm{~kg}^{-1}$ ) was calculated as the ratio between the leaf lamina area and its dry mass. Leaf dry matter content (LDMC, $\mathrm{mg} \mathrm{g}^{-1}$ ) was calculated as the ratio between dry and saturated fresh mass of the leaf lamina.

Leaves were ground with a stainless steel mill for nitrogen and $\delta^{13} \mathrm{C}$ content analysis. The nitrogen concentration was measured using an elemental analyser (Eurovector EA 3000; EuroVector SpA, Milan, Italy). The isotopic analysis of $\mathrm{C}\left(\delta^{13} \mathrm{C}\right)$ 
was carried out at the Laboratorio de Isótopos Estables of the Estación Biológica de Doñana (LIE-EBD, Spain). All samples were combusted at $1020{ }^{\circ} \mathrm{C}$ using a continuous flow isotope-ratio mass spectrometry system by means of Flash HT Plus elemental analyzer coupled to a Delta-V Advantage isotope ratio mass spectrometer via a CONFLO IV interface (Thermo Fisher Scientific, Bremen, Germany). Replicate assays of laboratory standards routinely inserted within the sampling sequence, and previously calibrated with international standards, indicated analytical measurement errors of $\pm 0.1 \%$.

For chlorophyll tissue concentration ( $\mathrm{LChl}, \mu \mathrm{g} \mathrm{g}^{-1}$ ), one circular portion of a leaf fresh lamina was cut and weighed. For plants with smaller leaves, where it was not possible to obtain a circular portion, such as $R$. officinalis and L. stoechas, three or four leaves were chosen and weighed. For Genista hirsuta, which possess photosynthetic spikes and no functional leaves, three or four spikes were selected and weighed. The chlorophyll concentration was obtained following the method of Wintermans \& de Mons (1965), using methanol for the extraction of chlorophyll in the leaf portion during 24 hours under dark conditions. The absorbance of the supernatant was analyzed by spectrophotometry at 650 and $655 \mathrm{~nm}$. The equation used was: leaf chlorophyll content $=25.5 \times \mathrm{A}_{650}+4 \times \mathrm{A}_{665}$. Leaf chlorophyll content was divided by the leaf fresh mass portion used to obtain LChl $\left(\mu \mathrm{g} \mathrm{g}^{-1}\right)$.

For stem traits, we selected young stems from the last growing season with an approximate length of $10 \mathrm{~cm}$. Stems were oven-dried for at least $48 \mathrm{~h}$ at $60{ }^{\circ} \mathrm{C}$ and weighed to obtain stem dry mass. Stem dry matter content (SDMC, $\mathrm{mg} \mathrm{g}^{-1}$ ) was obtained as the ratio between dry and saturated fresh mass.

To better understand the plant-soil interactions, we measured two functional traits from fine roots $(<2 \mathrm{~mm}$ in diameter $)$, which are related to water and nutrient 
uptake (Jackson 1997). We collected the root samples in the first $20-30 \mathrm{~cm}$ of soil digging close to the plant basal stem and we collected only those fine roots emerging from these primary roots. Sampling roots were stored in plastic bags to be transported to the laboratory and washed there with distilled water to remove soil residuals. Cleaned roots were maintained in water at $4^{\circ} \mathrm{C}$ for $24 \mathrm{~h}$ in darkness for a complete rehydration. Root measurements were obtained from fine roots $(<2 \mathrm{~mm}$ in diameter). Roots were weighed for saturated mass and scanned. Images were analyzed with WinRHIZO 2009 (Regent Instruments Inc., Quebec, Canada) for root length. Root dry mass was obtained after oven-drying them at $60{ }^{\circ} \mathrm{C}$ for $48 \mathrm{~h}$. Specific root length (SRL, m kg-1) was calculated as the ratio between root length and root dry mass. Root dry matter content (RDMC, $\mathrm{mg} \mathrm{g}^{-1}$ ) was obtained by dividing dry mass by saturated fresh mass.

\section{References}

Jackson, R.B., Mooney, H.A. \& Schulze, E.D. (1997) A global budget for fine root biomass, surface area, and nutrient contents. Proceedings of the National Academy of Sciences of the United States of America, 94, 7362-7366.

Klein, C.H. (2007). Lecture Notes for the Teaching Module Forest Inventory. Institute of Forest Management, Faculty of Forest Sciences and Forest Ecology. Georg August Universität, Germany, 164 p.

Wintermans, J.F.G.M. \& DeMots, A. (1965). Spectrophotometric characteristics of chlorophylls $\mathrm{a}$ and $\mathrm{b}$ and their pheophytins in ethanol. Biochimica et Biophysica Acta, 109, 448-453. 
Appendix 3.- Details of the method used to disentangle the relative importance of species occurrence, abundance and intraspecific variability on changes in community functional structure.

First, we calculated the three types of CWM parameters proposed by Leps et al. (2011):

(i) 'specific' average traits, using trait values of each species within each site, whose variation can be caused by both species turnover and intraspecific trait variability:

$$
\text { Specific parameter }=\sum_{i=1}^{S} p_{i} x_{i \_ \text {habitat }}
$$

where $\mathrm{p}_{\mathrm{i}}$ is the abundance of the $\mathrm{i}$-th species in a given community, $\mathrm{S}$ is the number of species in this community, and $\mathrm{x}_{\mathrm{i}}$ habitat is the specific mean trait value of the $\mathrm{i}$-th species, which is valid just for a given habitat sampled.

(ii) 'fixed' trait values, using mean trait values of each species along the whole environmental gradient (i.e. site-independent trait values), whose variation is only due to changes in species turnover:

$$
\text { Fixed parameter }=\sum_{i=1}^{S} p_{i} x_{i}
$$

Where $\mathrm{x}_{\mathrm{i}}$ is the fixed mean trait value of the $\mathrm{i}$-th species for all communities where the species is found.

(iii) 'intraspecific variabilitity' trait values, which are calculated from the differences between 'specific' and 'fixed' average traits and permit an estimation of the pure effects of the intraspecific variability: 
Second, we computed two new community parameters with the aim of disentangling the effects of the two components of species turnover (species occurrence and species abundance):

(i) 'unweighted' trait values (UWM), which were calculated similarly to the abovementioned 'fixed' trait values but without weighting them by their relative species abundances:

$$
\text { Unweighted parameter }=\sum_{i=1}^{S} \frac{1}{S} x_{i}
$$

(ii) 'species-abundance' trait values, calculated from differences between 'fixed' and 'unweighted' trait values. Thus, variation in the 'unweighted' trait values is solely affected by changes in species occurrence (presence/absence of species) whereas variation in 'species-abundance' trait values allows us to estimate the pure effects of changes in species abundance as follows:

Species abundance parameter $=$ Fixed parameter ('species turnover') - Unweighted parameter ('species occurrence')

Thus, the complete formula can be defined as:

$$
\text { Spi }=\left(\sum_{i=1}^{S} p_{i} x_{i \_ \text {habitat }}-\sum_{i=1}^{S} p_{i} x_{i}\right)+\left(\sum_{i=1}^{S} p_{i} x_{i}-\sum_{i=1}^{S} \frac{1}{S} x_{i}\right)+\sum_{i=1}^{S} \frac{1}{S} x_{i}
$$


Finally, we explored 'CWM traits - environment' linkages for the two new types of community parameters ('unweighted' and 'species-abundance' trait values) as well as for that used to estimate the pure effects of the intraspecific variability ('intraspecific variability' parameter). To quantify how much variability is accounted for by each individual component (species occurrence, abundance and intraspecific variability), we used the method based on the Sum of Squares (SS) decomposition from Leps et al. 2011, using the best likelihood models previously calculated. The SS can be decomposed into the amount of variability explained by individual terms of the model and the unexplained variability (error). Since the effects of the above-explained community parameters do not always vary independently, we also considered the effect of their covariation. In turn, covariation was partitioned into two different components, as specified in the equations: the covariation between species turnover and intraspecific variation (covSSI), and the covariation between species occurrence and abundance (covSSII), as specified in the following equations:

covSSI $=$ SS specific - SS fixed - SS intraspecific variability

covSSII $=$ SS fixed - SS species occurrence - SS species abundance

In summary, the maximum variability included in 'specific' average traits (i.e. that due to changes in species occurrence, abundance and intraspecific trait variability) can be defined as:

SSspecific $=$ SS species occurrence + SS species abundance + SS intraspecific variability + $\operatorname{covSSI}+\operatorname{covSSII}$

\section{Example:}

To illustrate this method we developed the results for the case of specific leaf area (SLA): 
Table 1. Results from linear regression model analysis for SLA along the gradient of SWS. The variability effects were analysed separately (species occurrence and abundance, intraspecific variability, turnover and specific average). Note that SS (sum of squares) corresponds to the amount of variability explained by each component.

\begin{tabular}{|c|c|c|c|}
\hline Parameter & SS & $\mathrm{F}$ & $p$ \\
\hline Species occurence (UWM) & 177.59 & 18.92 & 0.003 \\
\hline Species abundance (UWM-Fixed) & 0.84 & 4.46 & 0.073 \\
\hline Intraspecific variability (CWM-Fixed) & 1.17 & 0.37 & 0.963 \\
\hline Turnover (Fixed) & 202.96 & 19.59 & 0.003 \\
\hline Specific average (CWM) & 234.92 & 16.66 & 0.005 \\
\hline
\end{tabular}

Table 2. Variability of individual components of SLA variation (SSvar) and proportions of variability (SS\%) explained by individual factors. A) Covariation II (covSSII) is obtained by subtracting the first two columns from the last one (covSSII $=$ SSfixed - SS species occurrence - SS species abundance). B) Covariation I (covSSI) is obtained by subtracting the first four columns from the last one (covSSI = SS specific - SS fixed - SS intraspecific).

\begin{tabular}{lcccc}
\hline A) & $\begin{array}{c}\text { Species } \\
\text { occurence }\end{array}$ & $\begin{array}{c}\text { Species } \\
\text { abundance }\end{array}$ & covSSII & $\begin{array}{c}\text { Turnover } \\
\text { (Fixed) }\end{array}$ \\
\cline { 2 - 5 } SSvar & 177.59 & 0.84 & 24.53 & 202.96 \\
SS\% & 53.23 & 0.25 & 7.35 & 60.83 \\
\hline
\end{tabular}

\begin{tabular}{ccccccc}
\hline \multicolumn{1}{c}{ B) } & $\begin{array}{c}\text { Species } \\
\text { occurence }\end{array}$ & $\begin{array}{c}\text { Species } \\
\text { abundance }\end{array}$ & $\begin{array}{c}\text { Intraspecific } \\
\text { variability }\end{array}$ & covSSII & covSSI & $\begin{array}{c}\text { Total= } \\
\text { Specific }\end{array}$ \\
\cline { 2 - 7 } SSvar & 177.59 & 0.84 & 1.17 & 24.53 & 30.79 & 234.92 \\
SS\% & 53.23 & 0.25 & 0.35 & 7.35 & 9.23 & 70.42 \\
\hline
\end{tabular}




\section{Appendix 4.}

Table A1. Matrix of correlations among the 8 environmental variables considered in this study. Pearson correlation coefficients are shown in bold type when significant $\left(P<0.05^{*}, P<0.01^{* *}\right)$. The variables which were highly correlated among them $(\mathrm{K}, \mathrm{Ca}$ and $\mathrm{OM}$ ) were removed from the regression analysis. See Table 2 for variable abbreviations.

\begin{tabular}{lccccccc}
\hline & $\mathrm{pH}$ & $\mathrm{N}$ & $\mathrm{P}$ & $\mathrm{K}$ & $\mathrm{Ca}$ & $\mathrm{Mg}$ & $\mathrm{OM}$ \\
\hline $\mathrm{SWS}$ & 0.64 & -0.32 & 0.26 & -0.44 & 0.22 & -0.47 & -0.61 \\
$\mathrm{pH}$ & & 0.23 & 0.64 & 0.18 & $\mathbf{0 . 7 6 *}$ & -0.24 & -0.05 \\
$\mathrm{~N}$ & & & 0.31 & $\mathbf{0 . 8 4 * *}$ & $\mathbf{0 . 7 2 *}$ & 0.49 & $\mathbf{0 . 9 1 * *}$ \\
$\mathrm{P}$ & & & & 0.13 & $\mathbf{0 . 7 7 *}$ & 0.19 & 0.18 \\
$\mathrm{~K}$ & & & & & 0.57 & 0.42 & $\mathbf{0 . 8 0}$ \\
$\mathrm{Ca}$ & & & & & & 0.27 & 0.51 \\
$\mathrm{Mg}$ & & & & & & & 0.49 \\
\hline
\end{tabular}

Table A2. Results of a one-way ANOVA between zones and between slopes for noncorrelated abiotic variables.

\begin{tabular}{|c|c|c|c|c|c|c|c|c|c|c|c|c|c|c|c|c|c|c|c|}
\hline & \multicolumn{8}{|c|}{ Zones } & \multicolumn{11}{|c|}{ Slope } \\
\hline & \multicolumn{2}{|c|}{ Vlinares } & \multicolumn{2}{|c|}{ Popea } & \multicolumn{2}{|c|}{ Villaviciosa } & \multirow{2}{*}{$F$} & \multirow{2}{*}{$P$} & \multicolumn{3}{|c|}{ Upper } & \multicolumn{2}{|c|}{ Medium } & \multicolumn{3}{|c|}{ Lower } & & \multirow{2}{*}{$P$} \\
\hline & Mean & S.E & Mean & S.E & Mean & S.E & & & Mean & S.E & & Mean & S.E & & Mean & S.E & & & \\
\hline $\operatorname{SWS}\left(\mathrm{I} \mathrm{m}^{-2}\right)$ & 34.17 & 7.14 & 28.38 & 7.14 & 25.67 & 7.14 & 0.37 & ns & 19.40 & 3.76 & $b$ & 27.06 & 3.76 & $b$ & 41.76 & 3.76 & $a$ & 9.1 & 0.01 \\
\hline N (\%) & 0.14 & 0.02 & 0.18 & 0.02 & 0.12 & 0.02 & 2.73 & ns & 0.16 & 0.02 & & 0.15 & 0.02 & & 0.12 & 0.02 & & 1.35 & ns \\
\hline $\mathrm{P}\left(\mathrm{mg} \mathrm{kg}^{-1}\right)$ & 2.38 & 2.07 & 7.34 & 2.07 & 3.00 & 2.07 & 1.7 & ns & 2.73 & 2.45 & & 4.28 & 2.45 & & 5.71 & 2.45 & & 0.37 & ns \\
\hline $\mathrm{Mg}\left(\mathrm{mg} \mathrm{kg}^{-1}\right)$ & 216.2 & 68.1 & 478.5 & 68.1 & 348.9 & 68.1 & 3.7 & ns & 329.3 & 88.0 & & 444.3 & 88.0 & & 270.0 & 88.0 & & 1.01 & ns \\
\hline $\mathrm{pH}$ & 6.83 & 0.29 & 7.09 & 0.29 & 6.66 & 0.29 & 0.57 & ns & 6.80 & 0.24 & & 6.53 & 0.24 & & 7.24 & 0.24 & & 2.27 & ns \\
\hline
\end{tabular}




\section{Appendix 5:}

Table A1. PERMANOVA based on the Bray-Curtis dissimilarities of the multivariate data. SWS: Soil water storage, P: Phosphorous soil concentration, N: Nitrogen soil concentration, $\mathrm{pH}$ : Soil $\mathrm{pH}, \mathrm{Mg}$ : Magnesium soil concentration.

\begin{tabular}{ccccccc}
\hline Soil variable & Df & SumsOfSqs & MeanSqs & F.Model & $\mathrm{R}^{2}$ & $\operatorname{Pr}(>\mathrm{F})$ \\
\hline SWS & 1 & 0.88 & 0.88 & 3.39 & 0.31 & 0.008 \\
$\mathrm{P}$ & 1 & 0.26 & 0.26 & 1.01 & 0.09 & 0.423 \\
$\mathrm{~N}$ & 1 & 0.19 & 0.19 & 0.74 & 0.07 & 0.66 \\
$\mathrm{pH}$ & 1 & 0.32 & 0.32 & 1.21 & 0.11 & 0.323 \\
Mg & 1 & 0.43 & 0.43 & 1.66 & 0.15 & 0.135 \\
Residua1 & 3 & 0.78 & 0.26 & & 0.27 & \\
Tota7 & 8 & 2.86 & & & 1.00 & \\
\hline
\end{tabular}




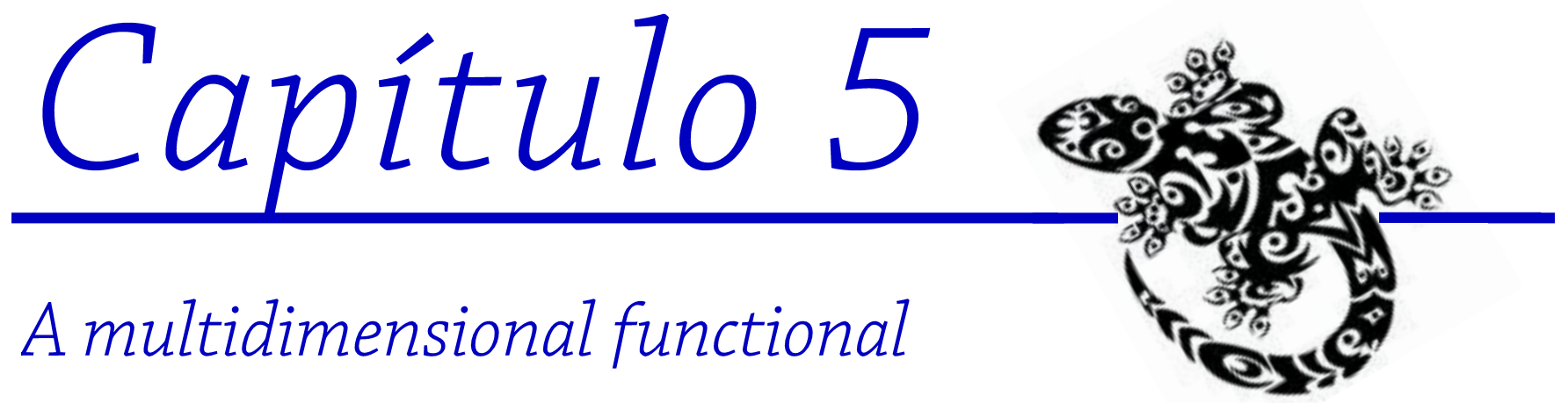
approach reveals the imprint of environmental stress in Mediterranean woody plant communities

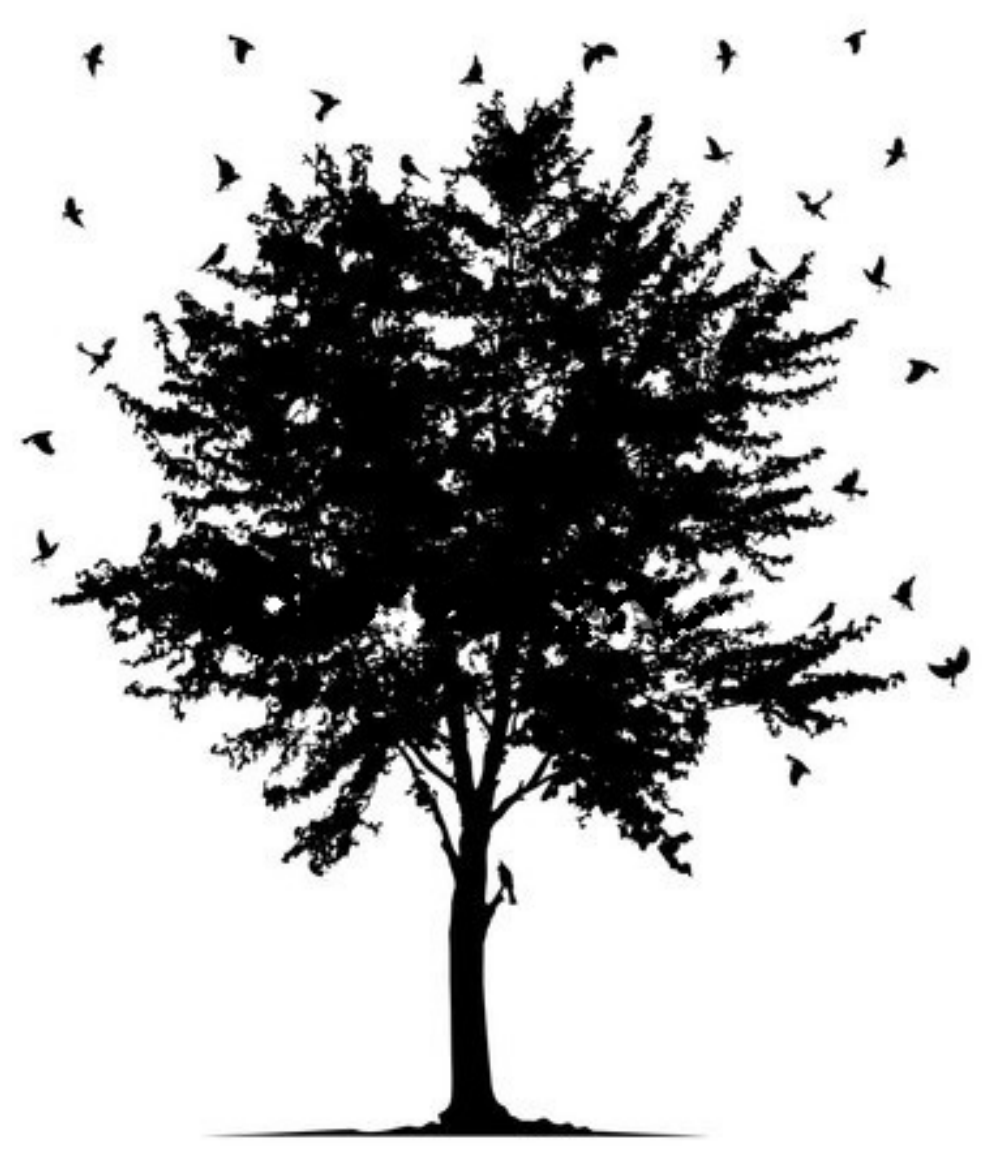

"El basque sería muy triste si sóla cantaran los pájaros que mejar la hacen"

Rabigranath Tagore 



\title{
A multidimensional functional trait approach reveals the imprint of en-
}

\section{vironmental stress in Mediterranean woody plant communities}

\author{
Enrique G. de la Riva ${ }^{1}$, Cyrille Violle ${ }^{2}$, Ignacio M. Pérez-Ramos ${ }^{3}$, Teodoro Marañón ${ }^{3}$, Carmen M. Nava- \\ rro-Fernández ${ }^{3}$, Manuel Olmo ${ }^{1}$, and Rafael Villar ${ }^{1}$
}

\begin{abstract}
${ }^{1}$ Area de Ecología, Facultad de Ciencias, Universidad de Cordoba. 14071 Cordoba, Spain; 2 CNRS, Centre d'Ecologie Fonctionnelle et Evolutive, Montpellier Cedex 5, France.; ${ }^{3}$ IRNAS, CSIC, Av. Reina Mercedes 10, P.O. Box 1052. 41080 Sevilla, Spain; ${ }^{5}$ Estación Biológica de Doñana, CSIC. c/ Americo Vespucio, s/n, Isla de la Cartuja. 41092 Sevilla, Spain
\end{abstract}

\begin{abstract}
Aim Water availability can be one the most limiting factors of the plant communities, affecting its distribution and functioning. In this study, we explore how the functional structure of woody Mediterranean communities varies along a regional gradient of aridity. We question if the functional structure of more arid communities is a subset of the functional structure of the communities located in wetter sites, or if instead there is a divergence in their niche spaces.
\end{abstract}

Location Mediterranean forests and shrublands, Andalusian region, south Spain.

Method We selected five Mediterranean woody communities along a regional aridity gradient. We measured 13 functional traits (in leaves, stems, roots) in 74 woody plant species. We quantified niche differences by using the n-dimensional space approach (hypervolumen), which is based on the Hutchinsonian's multidimensional niche concept.

Results We found consistent variation of functional traits and spaces along the aridiy gradient. We found a greater functional space for the wetter communities (i.e. larger hypervolumes) compared with the communities inhabiting drier soils, which showed higher overlap of the trait space occupation. This general trend for a multidimensional scale was different when considering only one dimension of traits (i.e leaf morphology).

Main conclusion Our results support that aridity acts as a key abiotic filter affecting various metrics of the community trait structure, according with the economics spectrum. We also documented consistent variation of the functional space, supporting the decrease in functional diversity under harsh climatic conditions. However, functional diversity seems largely to depend on the niche axis considered; thus root dimension was a decisive axis for the functional diversity of wet environments. In summary, our results indicate that the filtering process driving the functional structure of the study communities largely depend on the functional plant dimension considered, highlighting the use of the hypervolume approach as an useful tool to better understand the community assembly patterns and to quantify species functional niches over broad spatial patterns.

Keywords: Aridity $\bullet$ dry shrubland $\bullet$ functional diversity $\bullet$ functional structure $\bullet$ hypervolume $\bullet$ root traits $\bullet$ wet forest

\section{INTRODUCTION}

Trait-based approaches have been identified as fruitful tools to understand the biodiversity effects on ecosystem processes and underlying physiological mechanisms (Mason et al., 2005; Grime et al., 2006; Mouillot et al., 2011). However, they have been applied mostly in experimental conditions or along local environmental gradients (Bernard-Verdier et al., 2012; Maire et al., 2012; de la Riva et al., 2016a). This impedes a thorough evaluation of ecosystem functionality along large-scale environmental gradients, a high priority for functional biogeography (Violle et al., 2014). A notable exception is global modelling studies that classify ecosystems based on number of species and functional types diversity (Kleidon \& Mooney 2000; Thuiller et al., 2006; Kherkhoff et al., 2014) or even plant functional traits (Heberling \& Fridley 2012; Lamanna et al., 2014; Simova et al., 2014). However, those models typically refer to database approaches in which the real flora or phenotypic plasticity is largely ignored. In other words, woody ecosystems of a given biogeographic area are commonly described by a similar set of plant functional traits without accounting for its composition in species nor by intraspecific trait variation. In addition, the ecological strategies seem to be highly scale-dependent (Liu et al., 2010; Lamanna et al., 2014; de la Riva et al., 2016b), with functional strategies identified at lower spatial scales not necessarily matching with the patterns found at regional or global levels (Funk \& Cornwell 2013; de la Riva et al., 2016b). Thus, there is an urgent need for a functional understanding of ecosystem variability at higher spatial scales, with potential insights for both ecosystem and global change biology.

A trait-by-trait approach is a relevant tool to evaluate plant responses to environmental changes since a given trait can be straightforwardly related to abiotic or biotic constraints (Garnier \& Navas, 2012). Most importantly, this approach applied to plant ecosystems has been recently challenged (Laughlin et al., 2014; Lamanna et al., 2014) based on the idea that instead of the single trait, the study of whole-phenotype responses is more useful to understand the filtering effects of environmental factors on natural communities (Laughling, 2014). In this regard, root traits have been generally overlooked in studies of functional structure (i.e. composition and diversity of functional traits; Mouillot et 
al., 2011), despite the important role of root attributes on several key ecosystem processes (Crane et al., 2002). Root traits have been especially ignored at large spatial-scale studies where information on belowground traits is not usually available. For example, root trait data represent only the $7 \%$ in the TRY database (Freschet et al., unpublished). Thus, given the ndimensions of plant functions, the no consideration of several key functional traits such as those related to belowground functioning may strongly bias our estimation of community functional structure (Laughling, 2014). In fact, there is a lack of knowledge about how the use of different plant dimensions can determine functional diversity and structure.

A successful trait-based method to quantify the magnitude of the functional space is the $n$-dimensional space approach (Blonder et al., 2014), based on the Hutchinsonian's multidimensional niche concept (Hutchinson, 1957). Hutchinsonian niches allow us to quantify niche spaces by assessing the functional trait hypervolumes that characterize the phenotypic spaces occupied by a set of species (Lamanna et al., 2014). One of the main advantages of this method is that it can accurately measure the volume of a high-dimensional shape that may include holes or other complex geometrical features, which refine the measure of the functional space better than linear and continuous dimensions (i.e. the convex hull model; Cornwell et al., 2006). Also, it lets to measure which proportion of the hypervolumes overlap among different habitats, sharing the same functional space. Thus, the n-dimensional space makes possible to predict species niche shifts along environmental gradients (Violle et al., 2009), allowing to infer relevant processes such as competitive exclusion of species and functional redundancy within communities (see Blonder et al., 2014 and references therein). In spite of the great potential of this method to better understand the rules that govern the process of community assembly, it has been barely used in natural systems (but see Lamanna et al., 2014).

In arid and semi-arid regions, water availability is one of the main limiting resources for plants (Padilla \& Pugnaire, 2007), affecting many aspects of plant fitness and therefore of species composition and distribution (Breda et al., 2006; Engelbrecht et al., 2007). These arid conditions promote specific adaptations to the imposed climatic constraints, reflecting different functional trade-offs between nutrient acquisition, growth, or life span (Reu et al., 2011). Thus, communities inhabiting dry environments tends to be dominated by short, slow-growing species with higher values of tissue dry matter content and higher water-use efficiency (high values of $\delta^{13} \mathrm{C}$ ), which is known as a conservative resource-uptake strategy (Wright et al., 2004; de la Riva et al. 2015). On the contrary, highly productive ecosystems are dominated by plant communities with tall, fast growing species with high absorption surface per unit of tissue biomass (high specific leaf area and specific root area values) and high photosynthetic capacity (high nitrogen or chlorophyll concentration), indicating an acquisitive resource-uptake strategy (Violle et al., 2009; Mayfield \& Levine, 2010).
It has long been observed that the diversity of plant functional strategies (i.e. functional diversity) is largely conditioned by climate and, thereby, by soil resource availability. According to theory, a larger functional diversity is expected in resource-rich and productive environments (Heywood 1995) as a result of strong among-species competition, which promotes resource partitioning (limiting similarity hypothesis; MacArthur \& Levins 1967). On the contrary, in more resource-limited environments, plant adaptations to those stressful conditions are limited, constraining the phenotypic space and decreasing the plant functional diversity (Jacobsen et al., 2008). However, and contrary to this general pattern, some studies have shown lower diversity (for both species and functional richness) in more productive environments (Grime 2006, Michalet et al., 2006, Mayfield \& Levine 2010, de la Riva et al., 2011; Pakeman, 2011; de Bello et al., 2013), probably because more stressful conditions also imply a wider range of possible adaptations to survive (Stubbs \& Wilson, 2004). Hence, to address future predictions and better understand niche spaces and functional strategies under different scenarios of soil water availability is one of the increasingly urgent objectives from community ecology, especially under the climatic change perspective (IPCC 2013). Thus, there is a need to understand how aridity conditions determine the functional structure and volume of plant communities, and to test the hypothesis stating that the niche functional space of communities located in more arid conditions is lower than that included in communities inhabiting wetter sites.

In this paper, we explored a regional gradient of well-preserved woody Mediterranean plant communities from dry to permanently-wet conditions covering a wide natural area in South Spain. We measured a large variety of plant traits, including root traits, that represented main functional dimensions of the vegetative phenotype. Using a n-dimensional space approach, we tried to assess: i) whether and to what extent the functional trait structure of different communities was sensitive to the regional aridity gradient; ii) assuming functional trait variation, how niche functional space (hypervolume) varies along this gradient, and if the communities located under harsh environmental conditions display smaller hypervolumes; and iii) whether the patterns obtained for all traits are congruent with the hypervolumes calculated for each independent dimension of the phenotype (i.e. leaf and root morphology or leaf chemical composition).

\section{MATERIAL AND METHODS}

\section{Study area}

The study was conducted in four Mediterranean zones dominated by woody plant communities (forests and shrublands) located in Andalusia, south Spain (87 597 $\mathrm{km}^{2}$ ), that encompass a wide range of precipitation (from 200 to $2000 \mathrm{~mm} \mathrm{year}^{-1}$; Figure 1). Data layers for the aridity index (Fig.1) were extracted from the CGIAR consortium for spatial information (http:// www.cgiar-csi.org/). According with the Global- 

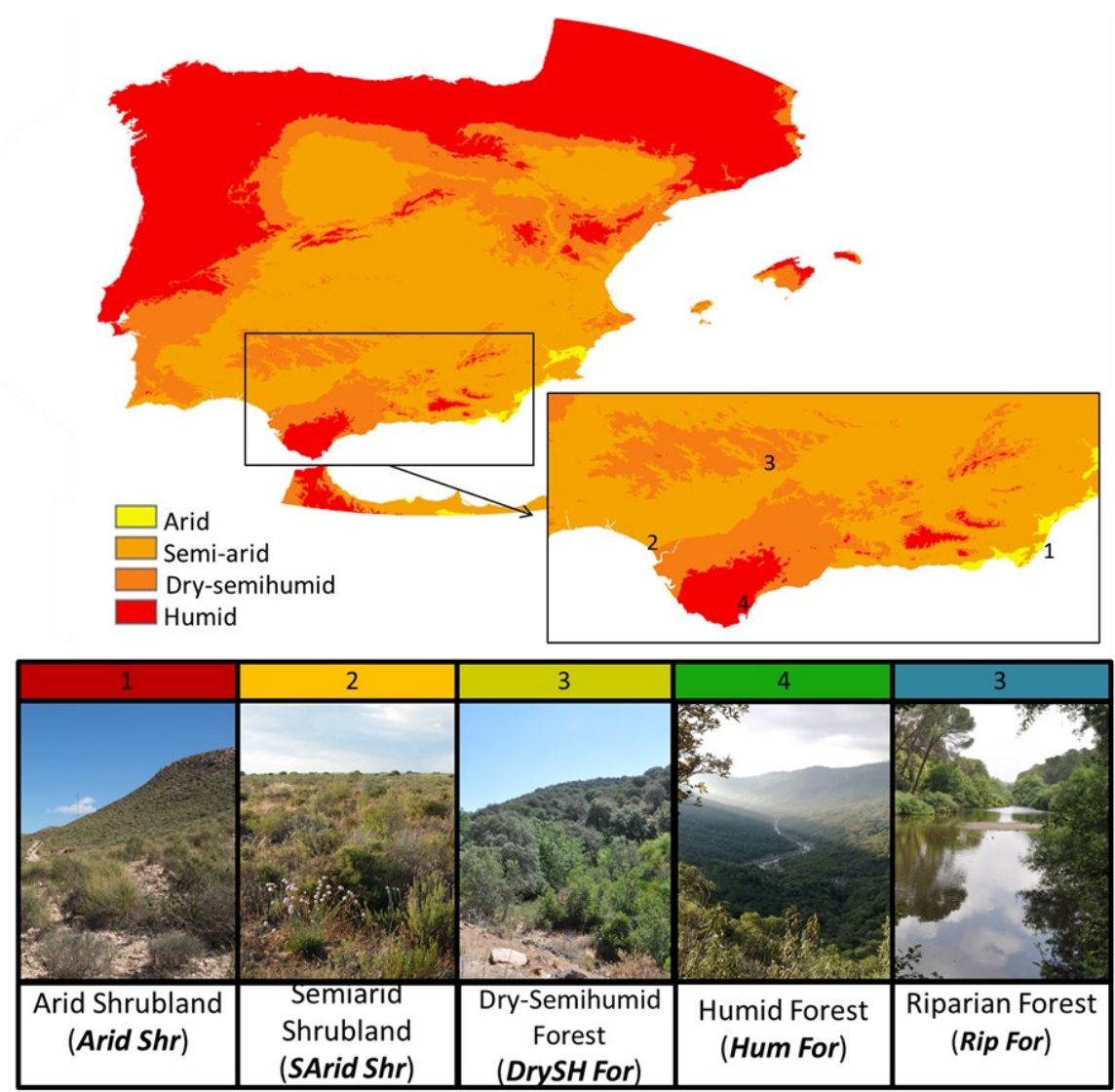

Figure 1. Location of the study zones (and abbreviations) selected along the regional aridity gradient. Aridity index map was generated in ArcGis software 10.2 (Trabucco \& Zomer, 2009).
Aridity datasets (Trabucco \& Zomer, 2009) the four studied zones can be classified as follows: i) Arid zone at 'Cabo de Gata' Natural Park, dominated by shrubland communities (e.g. Anthyllis citysoides, Helianthemum almeriensis) (hereafter Arid Shr); ii) Semi-Arid zone at Doñana National Park, dominated by shrublands on sandy soils .e.g. Halimium commutatum, Staurachantus genistoides) (hereafter SArid Shr); iii) Dry-Semihumid zone at Sierra Morena mountains, dominated by forest with drought-tolerant evergreen species (e.g. Arbutus unedo, Quercus ilex, Rosmarinus officinalis) (hereafter DrySH For); and iv) Humid zone at Los Alcornocales Natural Park, dominated by mixed forests of evergreen (Quercus suber) and winterdeciduous (Quercus canariensis) oaks (hereafter Hum For). To incorporate a very wet point into the aridity gradient, we added a riparian habitat within the Sierra Morena zone: v) Riparian Forest (hereafter Rip For) from Guadiato River (Sierra Morena mountains), with permanent water availability and dominated by deciduous tree species (e.g. Fraxinus angustifolia, Ulmus minor). For simplicity we will refer to five habitat-types throughout the article.

\section{Sampling design}

Three sampling sites per zone were selected (no further than $10 \mathrm{~km}$ between them). Four 20-m-long transects were randomly set up in each of the sampling sites, with a minimum distance of $10 \mathrm{~m}$ relative to one another and avoiding steep slopes. Species composition and abundance were recorded measuring the cover of each woody species intercepted by each of the four $20-\mathrm{m}$ transects.
For trait measurements (see details below), we selected all the species appearing in transects, excluding only those with a relative abundance below $0.5 \%$ since it was difficult to find at least six individuals per species in the sampling sites (in total, 12 species were discarded for trait measurements). This led to a total of 74 selected woody plant species, many of them occurring in more than one study zone (Appendix S1).

\section{Plant measurements}

Healthy adults of the woody plant species were randomly selected during the peak of plant growth (spring). We measured 13 key functional traits related to morphology (of leaf, stem and root), physiology (leaf chemical compounds) and plant size, covering the main plant functional dimensions (see functional roles in Table 1). All these trait measurements were carried out according to the criteria defined by PérezHarguindeguy et al. (2013). For a detailed protocol of sample harvesting and trait measurements, see de la Riva et al. (2016a).

Leaf morphological traits.- Six individuals per species and site were chosen, on which the following leaf traits were measured: leaf size (Lsize); specific leaf area (SLA; leaf area per unit of dry leaf mass); and leaf dry matter content (LDMC; dry mass per unit of watersaturated fresh mass).

Stem morphological traits.- On the same six individuals per species and site, we measured the following stem traits: Stem dry matter content (SDMC), which was obtained as the ratio between dry and saturated fresh mass; stem wood density (WD), which was 
Table 1. List of the 13 functional traits considered in this study, their abbreviations, units and main role in plant functioning.

\begin{tabular}{|c|c|c|c|c|}
\hline Group & Trait & Abbreviation & Unit & Functional role \\
\hline \multirow{3}{*}{ Leaf morphology } & Leaf size & Lsize & $\mathrm{cm}^{2}$ & Light capture and growth rate \\
\hline & Specific leaf area & SLA & $\mathrm{m}^{2} \mathrm{~kg}^{-1}$ & Light capture and growth rate \\
\hline & Leaf dry matter content & LDMC & $\mathrm{mg} \mathrm{g}^{-1}$ & Physical resistance and stress tolerance \\
\hline \multirow{2}{*}{ Stem morphology } & Stem dry matter content & SDMC & $\mathrm{mg} \mathrm{g}^{-1}$ & Resistant to physical hazards \\
\hline & Stem wood density & SWD & $\mathrm{g} \mathrm{cm}^{-3}$ & Physical resistance, growth rate and stress tolerance \\
\hline \multirow{3}{*}{ Root morphology } & Specific root lenght & SRL & $\mathrm{mg} \mathrm{g}^{-1}$ & Water and nutrients acquisition \\
\hline & Root dry matter content & RDMC & $\mathrm{mg} \mathrm{g}^{-1}$ & Resistant to physical hazards \\
\hline & Root density & TMDr & $\mathrm{g} \mathrm{cm}^{-3}$ & Physical resistance, growth rate and stress tolerance \\
\hline \multirow{2}{*}{ Plant Size } & Plant height & Phg & $\mathrm{m}$ & Dispersal distance, light capture, above-ground competition \\
\hline & Plant cover & Pco & $\mathrm{m}^{2}$ & Dispersal distance, light capture, above-ground competition \\
\hline \multirow{3}{*}{ Leaf Chemical } & Leaf nitrogen concentration & LN & $\%$ & Light capture and photosynthetic rate \\
\hline & Leaf chlorophyll & LChl & $\mu g g^{-1}$ & Light capture and photosynthetic rate \\
\hline & Isotopic carbon fraction & $\delta^{13} \mathrm{C}$ & $\%$ & Gas exchange and water-use efficiency \\
\hline
\end{tabular}

1 Based on fresh mass

calculated as the stem dry mass divided by its fresh volume (which was calculated according to the Archimedes principle, i.e., measuring the volume of water displaced by the immersion of the stem).

Root morphological traits.- The fine roots $(<2$ $\mathrm{mm}$ in diameter) of four individuals per species and site were used to measure belowground traits: specific root length (SRL, root length per unit of dry root mass), root dry matter content (RDMC, root dry mass per unit of water-saturated fresh mass) and root tissue mass density (TDMr, root dry mass per root volume). The root area and root volume data were obtained by analysing the scanned root samples with WinRHIZO 2009 (Regent Instruments Inc., Quebec, Canada).

Plant-size traits.- Plant height (Phg) and cover (Pco; canopy projection) were measured as functional traits commonly used to quantify plant size. Measurements were made on ten individuals per species using a metric tape (excepting some low-abundant species for which only six individuals were found, such as Crataegus monogyna in Sierra Morena, Withania frutescens in Cabo de Gata or Phillyrea latifolia in Alcornocales). In tall species, such as trees, plant height was estimated using the 'Christen height' meter, based on trigonometric principles (Klein 2007).

Leaf physiology and chemical traits.- Three chemical traits related to plant physiology were considered: leaf nitrogen concentration (LN), leaf chlorophyll (LChl, the concentration of chlorophyll per unit of fresh leaf mass) and leaf carbon isotopic ratio $\left(\delta^{13} \mathrm{C}\right)$. The LN and LChl were measured in leaves of six individuals per species and site, whereas the $\delta^{13} \mathrm{C}$ was analysed in a mixture of leaves from six different individuals per species and site.

\section{Data analyses}

To explore differences in functional structure between the five habitats, a one-way ANOVA for each trait considered in this study was carried out followed by post hoc multiple pairwise comparisons (Tukey's test). Variables were log transformed when necessary.

The total niche space of the community was calculated by the estimation of the n-dimensional hypervolume (Blonder et al., 2014), from the trait space occupied by the species pool in each zone. In order to reduce the number of dimensions (which is recommended for this analysis), we performed a PCA for each dimension (leaf, stem, root, leaf physiology and plant size) separately. With the first PCA axis of each dimension (which absorbed between 53 to $95 \%$ of variation, see more details in the results section), we calculated the hypervolume of each zone, using a multidimensional kernel density estimation (KDE) procedure (see Blonder et al., 2014 for mathematical details). The units of the hypervolumes are reported as the standard deviations of centred and scaled log-transformed trait values, raised to the power of the number of trait dimensions used ( $\left.\mathrm{sd}^{\text {number of dimensions }}\right)$. We also calculated the overlap between the hypervolumes of each zone with the correlations analysis of the "hypervolume" package, which compares the similarity between hypervolumes using the Sørensen index (see Blonder et al., 2015). In addition, to observe if functional trait overlap between zones was related with species similarity, we also calculated the Sørensen index of similarity for species composition between each zone pair. A rarefied analysis was performed to control for effects of species richness on the hypervolume. Thus, for each zone, we built 100 randomized communities composed of species drawn (12 species) from the species pool of that zone. Then, we calculated the hypervolume of each sample and we performed a one-way ANOVA with them to compare the hypervolumes between zones.

Next, in order to examine whether hypervolume variations are consistent for different functional dimensions, we performed the same analysis (previously explained) for each dimension separately: leaf morphology (Lsize, SLA and LDMC), root (SRL, $\mathrm{RDMC}$ and TDMr) and leaf physiology traits (LN, 
LChl and $\delta^{13} \mathrm{C}$ ). We also calculated the rarefied analysis for each of these dimensions. Since the hypervolume analysis needs at least three variables, Stem and Plantsize dimensions (with only two traits each other) were discarded for these specific analysis. All the trait values were previously scaled by log-transformation to calculate hypervolumes with the same scale (Lamanna et al., 2014).

All these analyses were conducted in the $\mathrm{R}$ $2 \cdot 10 \cdot 0$ statistical platform (R Development Core Team 2011), using the packages "vegan" (Dixon, 2003) and "hypervolume" (Blonder et al., 2014).

\section{RESULTS}

Functional trait variation along the aridity gradient

We detected large trait variability among the species composing the different sampling communities. Thus, communities inhabiting wetter zones (Humid For and Ripar For) were dominated by species harbouring high values of Leaf size (Lsize), specific leaf area (SLA), specific root length (SRL), Leaf chlorophyll (LChl), Plant height (Pheight) and Plant cover (Pcover) (Fig. 2 and Appendix S2). On the contrary, the arid and semiarid shrublands showed a dominance of species with high values of stem wood density (SWD) and root dry matter content (RDMC) (higher in semiarid shrubland). Interestingly, the arid shrublands showed the lowest values of leaf dry matter content (LDMC) and the highest values of $\mathrm{LN}$ (close to those found in the riparian forest). The dry-semihumid forest showed generally intermediate values for most of the measured traits (i.e. Lsize, SRL, RDMC, LChl, Phg and Pco) or similar to that of the arid and semiarid shrublands (SLA, SWD and LChl). The only exception was SDMC, which showed the highest value in these zones (Fig. 2 and Appendix S2).

Functional trait hypervolumen along the aridity gradient

We calculated the hypervolumen space for each of the five habitats considering five plant dimensions (leaf, root and stem morphology, leaf physiology and plant size). Since we measured several traits for each of these dimensions, we finally used a single PCA axis for each of them (Table 1). The PCAs of each trait dimension showed high scores for their respective first principal components $(63,95,84,53$ and $94 \%$ of overall variation explained for leaf, stem and root morphology, leaf physiology and plant size, respectively). We used these first axes of the PCA to perform the hypervolumes of the woody plant communities inhabiting along the aridity gradient.

The results from the n-dimensional hypervolume approach showed the greatest functional space for the riparian forest (Fig. 3A) at the 5 plant dimensions (leaf, stem, root, leaf physiology and plant size). In addition, after standardizing for species richness, the functional space showed significant variation along the aridity gradient, with significantly higher hypervolume sizes for the wet than for dry zones $(P<0.001$; Fig. 3B).

The degree of overlapping among the hypervolumes of the different communities was variable, ranging from 0 to $30 \%$ (Fig. 4). The overlap was higher between the dry environments (Arid Shr and SArid $\boldsymbol{S h} \boldsymbol{r}$ ) and lower when comparing these dry environments with the riparian forest. Interestingly, the lower values of the hypervolumes and higher overlap among them on driest environments indicate that trait space occupation of different species pools in wet communities is much more variable than in driest communities. In spite of the functional space overlap between dry environments, the percentage of similarity in species composition was lower than $20 \%$ (Fig. 4), while the wet zones showed higher similarity indices between them (Sørensen $=40 \%)$. In addition, species composition was very different among wet (river and humid forest) and dry zones (dry forest and arid and semiarid shrublands).

Hypervolume space is dependent on functional dimensions

The hypervolume variations were different when we considered the plant dimensions separately (Appendix $\mathrm{S} 3$ and Fig. 5). Thus, the dry communities showed the greatest functional space for leaf morphology (Arid Shr $=19.5 \pm 6.8 \mathrm{SD}^{3} \mathrm{sd}^{3}$; Fig. 5A) and physiology dimensions (SArid Shr $=0.98 \pm 0.14 \mathrm{SD}^{3} \mathrm{sd}^{3}$; Fig. 5C), followed by the wet community in both cases (Rip For $=$ $11.8 \pm 2.5 \mathrm{SD} \mathrm{sd}^{3}$ for leaf and $0.61 \pm 0.13 \mathrm{SD} \mathrm{sd}^{3}$ for physiology dimension). However, the wet communities showed the highest values for the root dimension (Rip $\boldsymbol{F o r}=2.93 \pm 1.0 \mathrm{SD} \mathrm{sd}^{3}$ and $\boldsymbol{H u m} \boldsymbol{F o r}=1.85 \pm 0.5 \mathrm{SD}$ $\mathrm{sd}^{3}$; Fig. 5B). Dry semihumid forest displayed the lowest functional spaces in all cases.

\section{DISCUSSION}

Functional trait variation along the regional aridity gradient

In this study, we detected a consistent variation of several components of functional trait structure in Mediterranean woody plant communities over a regional environmental gradient, providing interesting insights into the effects of aridity as a main driver of plant community assembly under these particular environmental conditions. Our results found that the different plant dimensions of trait variation were strongly related with the economics spectrum theory, which is a broadly well -accepted notion at both local (Freschet et al., 2010; de la Riva et al., 2016a,b) and global scale (Wright et al., 2004). On the one hand, communities growing in wet habitats (e. g. riparian and humid forest habitats) were dominated by fast growing, acquisitive species (with large values of SLA, LN, LChl and plant size). These functional traits allow species to compete for space and light, which has been usually identified as main limiting factors in productive ecosystems (Poorter and Markesteijn, 2008; Bernard-Verdier et al. 2012; PérezRamos et al. 2012). On the other hand, plant communi- 

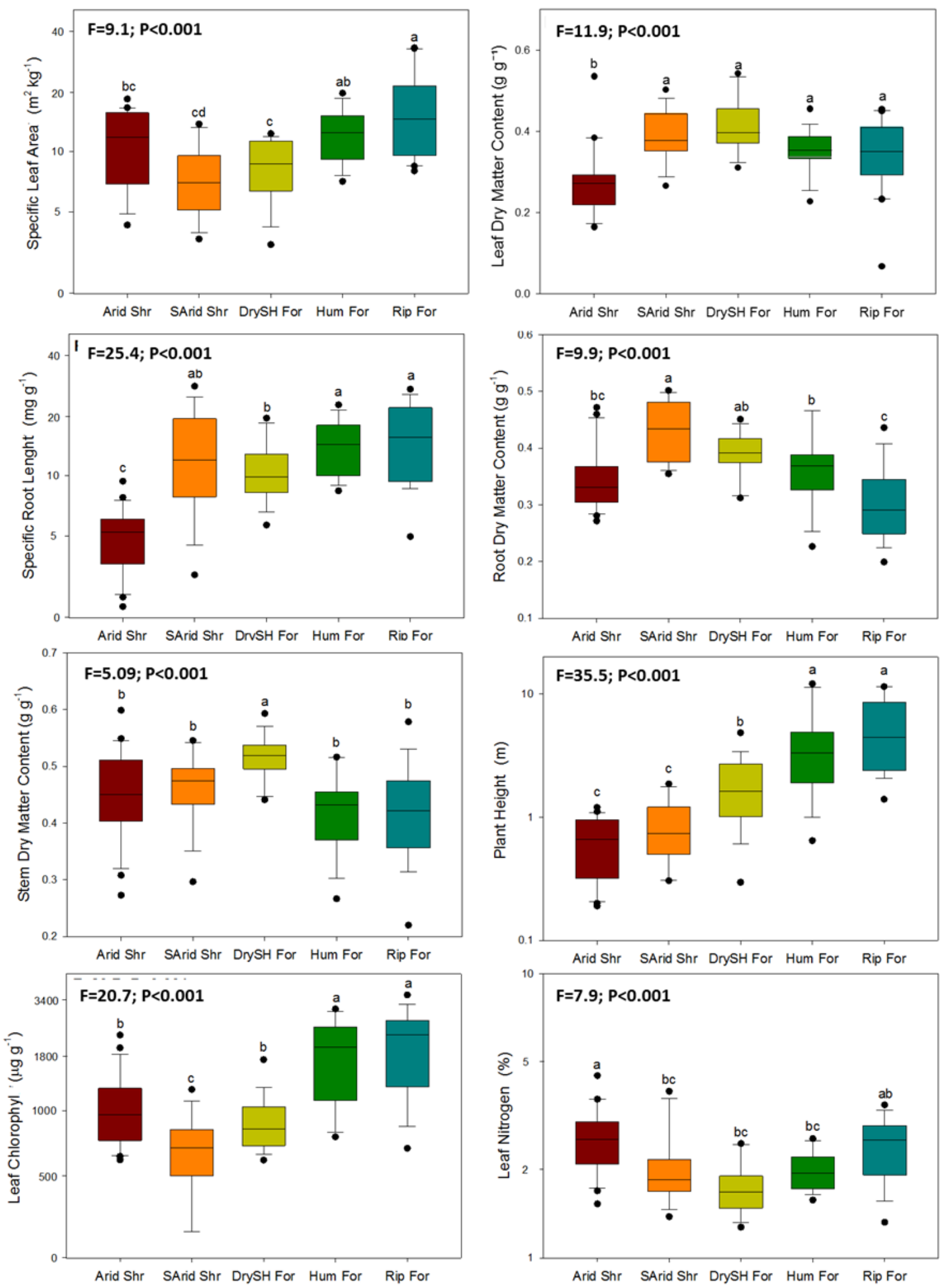

Figure 2. Box-plot of functional trait composition between zones calculated considering all the species sampled in each of them. The line inside the box represent the mean value, the box limits the SE and the whiskers the SD. Different letters indicate significant differences $(P<0.05)$ among the habitats. Some traits were previously log-transformed in order to fulfil the ANOVA assumptions (SLA, SRL, Phg, LChl, LN). The F and P values of the ANOVA are also shown. 


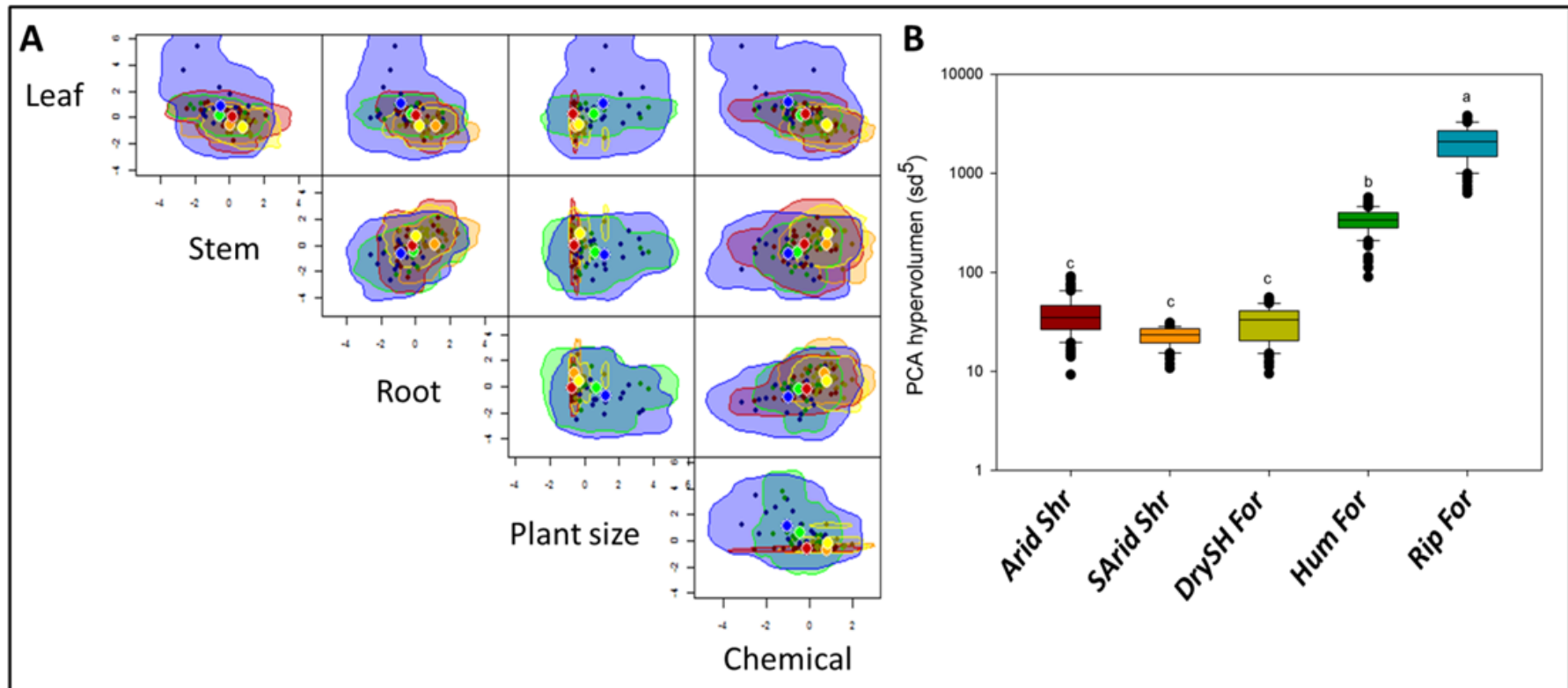

Figure 3. A) Estimated five-dimensional hypervolumes for the five habitats listed in the bottom (see also Fig. 1). Each plant dimension was based on the first PCAs axes of the different traits belonging to this dimension (Table 1). B) Box-plot of hypervolume of the five habitats along the regional gradient of water stress. The line inside the box represent the mean value, the box limits the SE and the whiskers the SD. Different letters indicate significant differences $(P<0.05)$ among habitats according to a one-way ANOVA analysis $(P<0.001)$.

ties inhabiting dry habitats (arid and semiarid shrublands and dry forest) showed in general traits related with different levels of drought tolerance, such as small plant size, slow growth rates and evergreen, sclerophyll leaves (with lower values of Lsize and SLA, and higher SWD). The general pattern obtained for the studied communities is consistent with previous studies in Mediterranean woody plant species at a local scale (Poole \& Miller, 1981; Cornwell \& Ackerly, 2009; de la Riva et al., 2016a), where trait variation seemed to be also related with the trade off between conservation andacquisition of resources. Our results highlight the importance of water restriction as a major driver of functional trait distribution in Mediterranean environments at a larger (regional) spatial-scale.

Variation of niche functional space along the regional aridity gradient

We documented here a consistent variation of functional space (hypervolumes) along a regional gradient of aridity, showing smaller hypervolumes in more stressful environments. These results are in accordance with other previous studies that found a lower functional diversity under more stressful climatic conditions (Tilman, 1992; Kleidon \& Mooney, 2000). In dry conditions, woody plants may exhibit different sets of functional traits (Jacobsen et al. 2008), but this diversification of strategies is limited within the range of viable traits that allow plants to persist in this arid environment (de la Riva et al. 2016b). Thus, water scarcity limits the establishment of species that are not physiologically able to tolerate those abiotic constraints, reducing thus the range of functional traits. For example, it would be expected that water limitation acts as a filter excluding from these environments fast-growing species (with a more exploitative strategy) and limiting the functional space to more conservative functional traits (Ackerly \& Cornwell, 2009; de la Riva et al., 2016a). On the contrary, we found larger hypervolumes in wetter zones (in riparian and humid forests). When no water limitation exists, another secondary filters probably occurs (Cingolani et al., 2007). For example, in riparian and humid forests, the dense shade created by the most dominant fast-growing species induces a great competition for light among them (de la Riva et al., 2016a), promoting the acquisitive strategy as the most advantageous for coping a competitive exclusion (Reich et al., 1992; Mayfield \& Levine, 2010). This strong amongspecies competition may determine a closer niche packing and smaller hypervolumes (Lamanna et al., 2014).

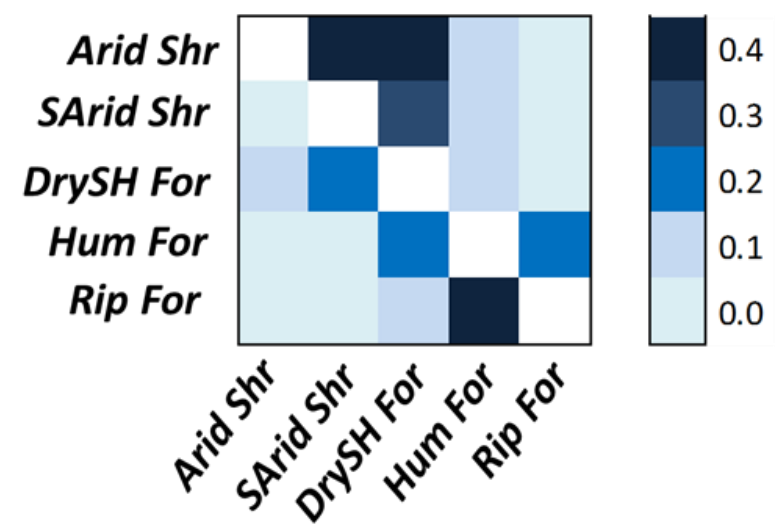

Figure 4. Sørensen similarity index among functional niche space (above the diagonal) and among vegetation composition (below the diagonal). 
In the studied wet communities, we found larger functional space. This could be due to several factors. First, the large functional space of the communities inhabiting wetter habitats could result from a process of niche differentiation (Ackerly \& Cornwell, 2007), that promotes the over-dispersion of traits for the coexistence between organisms with differing traits (Stubbs \& Wilson, 2004; Grime, 2006). For example, it is remarkable the existence of different plant adaptations to this competitive environment, like lianas (i.e. Hedera helix or Smilax aspera) or plants with phyllodes (i.e. Ruscus aculeatus). Secondly, in productive and
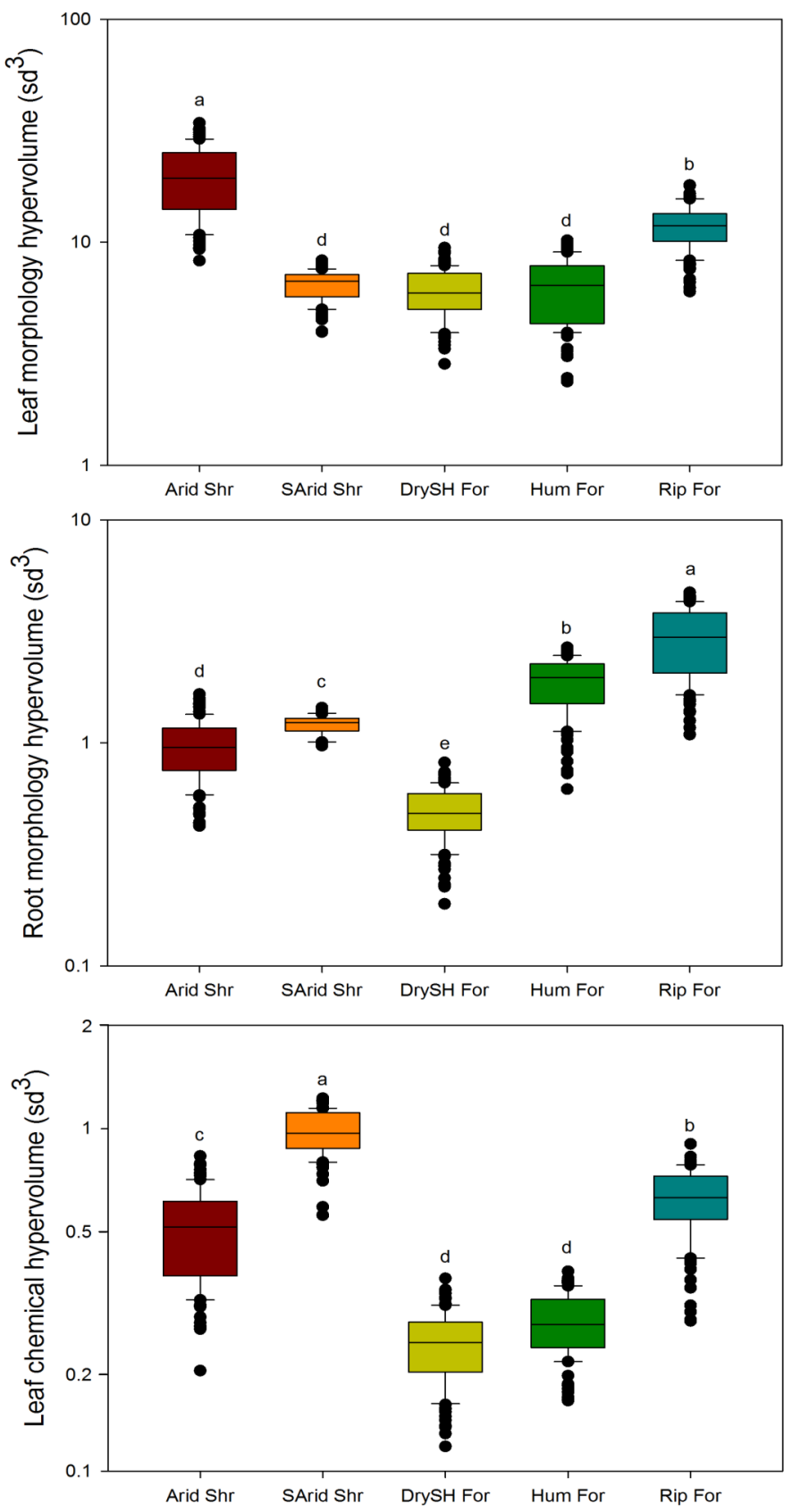

Figure 5. Box-plots of hypervolume variations for each plant dimension (leaf and root morphology and leaf chemical traits) on the five studied habitats along the regional gradient of water stress. Different letters indicate significant differences $(P<0.05)$ among habitats according to post hoc multiple pairwise comparisons (Tukey's test). The results from ANOVA analyses were significant in all cases $(P<0.001)$. patchy habitats, the competition for water and light may limit the spatial aggregation of taller, resourceacquisitive species, facilitating the persistence of smaller and less competitive species in the remaining open areas (Gross et al., 2013 and references therein). Thus, the gap spaces resulting from different disturbance processes (e.g. rivers flood or canopy tree death) could be relevant for the functional heterogeneity of these habitats (see Biswas, 2010), promoting the colonization of pioneers species such as some shrubs (i.e. Cistus salvifolius, Pistacia lentiscus or Rhamnus lycioides).

The communities from dry environments (Arid Shr, SArid Shr and DrySH For) showed smaller hypervolumes with a higher degree of overlapping between them, contrary to communities from wet environments. These results suggest that trait space occupation in wetter zones is much more variable than in driest zones. Further, the higher similarity among the hypervolumes of the dry communities showed higher overlaps in terms of functional structure than in terms of species composition (Figure 4), highlighting that arid and dry environments share higher niche overlap for functional structure than species similarity. This could suggest that there is a strong pressure for a similar resource use strategy (Mason et al., 2011), and supports the role of aridity in Mediterranean regions as a potential convergence force clustering trait values of the regional pool (Gross et al., 2013). In contrast, the wetter habitats (Humid and Ripar For) showed higher similarity in species composition than in functional structure, which could imply higher functional over-dispersion among these zones for the unshared species. Similar results were obtained by de Bello et al. (2007), who suggested that the mechanisms related with community functional assembly do not necessarily match with those promoting species coexistence. Hence, species richness indices may not be replaced always byindices of functional diversity (de Bello et at. 2007).

In conclusion, our study highlights the use of the hypervolume approach as a useful tool to understand the community assembly patterns and quantify species niche over a broad regional scale. In addition, the processes of functional trait convergence or divergence may be the result of the trade-off between habitat constraints (both environmental filtering and disequilibrium) and limiting similarity (Garnier \& Navas 2012; Blonder et al., 2015).

Congruency of niche functional spaces among different plant dimensions

The obtained trends for the multidimensional trait hypervolume were different when considering separately the plant dimensions. Thus, we found higher niche space dimensions in arid and semiarid shrublands for leaf morphology and physiology dimensions respectively, while the wetter environments (Hum For and Rip For) showed higher hypervolumes for the root dimension. The absence of a general and clear pattern when comparing results at different trait dimensions (i.e. leaf and root morphology), suggests that the functional diversity can largely depend on the niche axis 
considered. Similar results were obtained by Mason et al. (2011), which found dissimilar niche overlap for different traits related with similar aspects of plant strategy. These results reinforce the hypothesis that the strength of the filtering process could also depend on the trait studied (Grime, 2006), because this filtering process affects independently each trait dimension (de Bello et al., 2013; Laughlin et al., 2014). Therefore, within the range of viable functional traits to persist under particular environmental conditions (Keddy, 1992), the diversification of successful strategies tended to exist (de la Riva et al., 2016b), facilitating the species coexistence by complementary uses of resources (Stubbs \& Wilson, 2004). For example, the arid shrubland showed the highest niche space for leaf morphology, but it was relatively low for the root dimension. The soils of these arid zones were very shallow and poor in nutrients (data not shown), which could be a strong constraint to let a large root trait diversification; however, different growth forms could take place at the leaf level (e.g. evergreen, semi-deciduous and summerdeciduous shrubs coexist in these habitats), which were related with different resource uptake and drought survival strategies (Gálmes et al., 2005; Jacobsen et al., 2008). Hence, this widespread of functional leaf diversity may provide resilience to drought, supporting thus the 'limiting similarity principle' (Diamond, 1975; Pacala \& Tilman, 1994), but only for a specific dimension and within the range of viable trait values for these particular abiotic conditions.

The lower functional diversity detected in communities from the most arid habitats reflected a relatively homogeneous functional structure dominated by short-size shrubs with a predominant resourceconservative strategy (see also Jacobsen et al., 2008; Grubb et al., 2015). However, other studies found a lower functional diversity in more benign conditions (Mayfield \& Levine 2010; Pakeman, 2011; de Bello et al., 2013). These contradictory results could result from the comparison of different scales and different diversity indices or growth forms (i.e. herbaceous/woody species), which do not necessarily support the global patterns (de Bello et al. 2007; Funk and Cornwell 2013; Lamanna et al. 2014). In the light of our results, the considered trait dimension could be also an important factor to be into account. In this regard, most of the studies linking plant functional diversity and environmental factors are biased to aboveground traits, often ignoring the root dimension. Therefore, our results reinforce: (i) the importance of considering a multidimensional approach, which implies the inclusion of root attributes, as a decisive axis of functional diversity variation to better understand the role of aridity as a driver of community functional structure in Mediterranean environments; and (ii) the fact that extrapolations and comparisons among studies require a careful interpretation (de Bello et al. 2007).

Future insights: evaluating the potential impact of climatic change

According with the predictions of climate change models (IPCC 2013), an increase of aridity is expected in many areas with a consequent loss of species richness (Chapin III, 2003). Despite this general trend, understanding the idiosyncrasy of each ecosystem is important to face up the potential impacts predicted by climate change (de Bello et al., 2013). Contrary to the predicted trend by the theory, a higher functional diversity does not necessary imply a higher resilience to climatic change (Grossiord et al. 2014). Our results showed that the wettest ecosystems worked as a reservoir of high functional diversity. However, previous studies suggested that the new environmental conditions could negatively affect the winter-deciduous plants in our latitudes (Thuiller et al., 2006). This could promote the replacement of species by others with different functional syndromes, with potential effects on ecosystem functioning (Walker, 1992; Rosenfeld, 2002). On the contrary, the great functional diversity of the leaf dimension detected in the studied dry habitats may offer a wide range of possible adaptations to cope with water stress (Stubbs \& Wilson, 2004; Mason et al., 2005), which in fact could imply a higher resilience against the ongoing increased aridity. The fact that particular dimensions of the functional community structure respond differently along the aridity gradient makes relevant this kind of studies for modelling the vegetation responses to the ongoing climate change. However, more researches along regional gradients not only in Mediterranean but also in other biomes worldwide are needed to better understand the community assembly process and to forecast the consequences of the new environmental conditions for ecosystem functions and services.

\section{ACKNOWLEDGEMENTS}

This study was funded by the Spanish MEC coordinated project DIVERBOS (CGL2011-30285-C02-01 and C02-02), the Andalusian ANASINQUE project (PGC2010RNM-5782), the Life + Biodehesa Project (11/BIO/ ES/000726), ECO-MEDIT (CGL2014-53236-R) and European FEDER funds. Thanks to Emilio Retamosa and Vicky Schwarzer from the Cabo de Gata Natural Park for field assistant and plant classification. Isotopic analysis was carried out in the LIE (EBD-CSIC) and analysis of leaf $\mathrm{N}$ in the SCAI of the University of Córdoba.

\section{REFERENCES}

Bernard-Verdier, M., Navas, M. L., Vellend, M., Violle, C., Fayolle, A., \& Garnier, E. (2012) Community assembly along a soil depth gradient: contrasting patterns of plant trait convergence and divergence in a Mediterranean rangeland. Journal of Ecology, 100, 1422-1433.

Blonder, B., Lamanna, C., Violle, C., \& Enquist, B.J. (2014) The n-dimensional hypervolume. Global Ecology and Biogeography, 23, 595-609.

Bréda N, Huc R, Granier A, Dreyer E. (2006) Temperate forest trees and stands under severe drought: a review of ecophysiological responses, adaptation processes and long-term consequences. Annals of Forest Science, 63, 625-644.

Chapin, F.S. (2003). Effects of plant traits on ecosystem and regional processes: a conceptual framework for predicting the consequences of global change. Annals of 
Botany, 91, 455-463.

Cornwell, W.K. \& Ackerly, D.D. (2009). Community assembly and shifts in plant trait distributions across an environmental gradient in coastal California. Ecological Monographs, 79, 109-126.

Cornwell, W.K., Schwilk, D.W. \& Ackerly, D.D. (2006). A trait-based test for habitat filtering: convex hull volume. Ecology, 87, 1465-1471.

Craine, J.M., Wedin, D.A., Chapin, F.S., \& Reich, P.B. (2003) Relationship between the structure of root systems and resource use for 11 North American grassland plants. Plant Ecology, 165, 85-100.

de Bello, F.D., Lavorel, S., Lavergne, S., Albert, C.H., Boulangeat, I., Mazel, F. \& Thuiller, W. (2013). Hierarchical effects of environmental filters on the functional structure of plant communities: a case study in the French Alps. Ecography, 36, 393-402.

Bello, F., Lepš, J., Lavorel, S., \& Moretti, M. (2007). Importance of species abundance for assessment of trait composition: an example based on pollinator communities. Community Ecology, 8, 163-170.

de Bello, F., Thuiller, W., Lepš, J., Choler, P., Clément, J.C., Macek, P., Sebastià, M.T. \& Lavorel, S. (2009) Partitioning of functional diversity reveals the scale and extent of trait convergence and divergence. Journal of Vegetation Science, 20, 475-486.

Biswas, S.R., \& Mallik, A.U. (2010) Disturbance effects on species diversity and functional diversity in riparian and upland plant communities. Ecology, 91, 28-35.

Blonder, B., Nogués-Bravo, D., Borregaard, M. K., et al. (2015) Linking environmental filtering and disequilibrium to biogeography with a community climate framework. Ecology, 96, 972-985.

Bonser, S.P. (2006) Form defining function: interpreting leaf functional variability in integrated plant phenotypes. Oikos, 114, 187-190.

Cingolani, A.M., Cabido, M., Gurvich, D.E., Renison, D., \& Díaz, S. (2007) Filtering processes in the assembly of plant communities: Are species presence and abundance driven by the same traits? Journal of Vegetation Science, 18, 911-920.

Diamond, J.M. (1975) Assembly of species communities. Ecology and Evolution of Communities (eds M.L. Cody \& J.M. Diamond), pp. 342-444. Harvard University Press, Cambridge.

de la Riva, E.G., Casado, M.A., Jiménez, M.D., Mola, I., Costa-Tenorio, M., \& Balaguer, L. (2011). Rates of local colonization and extinction reveal different plant community assembly mechanisms on road verges in central Spain. Journal of Vegetation Science, 22, 292302.

de la Riva E.G., Pérez-Ramos I.M., Tosto A., NavarroFernández, C.M., Olmo, M., Marañón, T., \& Villar, R. (2016a) Disentangling the relative importance of species occurrence, abundance and intraspecific variability in community assembly: a trait-based approach at the whole-plant level in Mediterranean forests. Oikos doi:10.5061/dryad.dr275.

de la Riva E.G., Tosto A., Perez-Ramos I.M., NavarroFernández, C.M., Olmo, M., Anten, N.P., Marañón, T., \& Villar, R. (2016b) A plant economics spectrum in Mediterranean forests along environmental gradients: is there coordination among leaf, stem and root traits? Journal of Vegetation Science, 27, 187-199.

Engelbrecht B.M.J., Comita L.S., Condit R., Kursar T.A., Tyree M.T., Turner B.L., Hubbell S.P. (2007) Drought sensitivity shapes species distribution patterns in tropical forests, Nature 447, 80-82.
Freschet, G.T., Cornelissen, J.H., Van Logtestijn, R.S., \& Aerts, R. (2010) Evidence of the 'plant economics spectrum'in a subarctic flora. Journal of Ecology, 98, 362-373.

Galmes, J., Cifre, J., Medrano, H., \& Flexas, J. (2005) Modulation of relative growth rate and its components by water stress in Mediterranean species with different growth forms. Oecologia, 145, 21-31.

Garnier, E., \& Navas, M.L. (2012) A trait-based approach to comparative functional plant ecology: concepts, methods and applications for agroecology. A review. Agronomy for Sustainable Development, 32, 365-399.

Grime, J.P. (2006) Trait convergence and trait divergence in herbaceous plant communities: mechanisms and consequences. Journal of Vegetation Science, 17, 255260.

Gross, N., Börger, L., Soriano-Morales, S.I., et al. (2013) Uncovering multiscale effects of aridity and biotic interactions on the functional structure of Mediterranean shrublands. Journal of Ecology, 101, 637-649.

Grossiord, C., Granier, A., Ratcliffe, S. et al. (2014) Tree diversity does not always improve resistance of forest ecosystems to drought. Proceedings of the National Academy of Sciences, 111, 14812-14815.

Heberling, J. M. \& Fridley, J.D. (2012) Biogeographic constraints on the world-wide leaf economics spectrum. Global Ecology and Biogeography, 21, 1137-1146.

Heywood VH (1995) (ed.). Global Biodiversity Assessment. Cambridge University Press, England.

Hutchinson G.E. (1957) Cold Spring Harbour Symposium on Quantitative Biology. Concluding remarks, 22, 415427.

Jacobsen, A. L., Pratt, R.B., Davis, S.D., \& Ewers, F.W. (2008) Comparative community physiology: Nonconvergence in water relations among three semi-arid shrub communities. New Phytologist, 180, 100-113.

Keddy, P.A. (1992). Assembly and response rules: two goals for predictive community ecology. Journal of Vegetation Science, 3, 157-164.

Kerkhoff, A.J., Moriarty, P.E., \& Weiser, M.D. (2014). The latitudinal species richness gradient in New World woody angiosperms is consistent with the tropical conservatism hypothesis. Proceedings of the National Academy of Sciences, 111, 8125-8130.

Kleidon, A., \& Mooney, H.A. (2000) A global distribution of biodiversity inferred from climatic constraints: results from a process-based modelling study. Global Change Biology, 6, 507-523.

Lamanna, C., Blonder, B., Violle, C., et al. (2014). Functional trait space and the latitudinal diversity gradient. Proceedings of the National Academy of Sciences, 111, 13745-13750.

Laughlin, D. C. (2014) The intrinsic dimensionality of plant traits and its relevance to community assembly. Journal of Ecology, 102, 186-193.

Liu, G., Freschet, G.T., Pan, X., Cornelissen, J.H., Li, Y., \& Dong, M. (2010) Coordinated variation in leaf and root traits across multiple spatial scales in Chinese semi-arid and arid ecosystems. New Phytologist, 188, 543-553.

MacArthur, R.\& Levins, R. (1967) The limiting similarity, convergence, and divergence of coexisting species. The American Naturalist, 101, 377-385.

Maire, V., Gross, N., Börger, L., et al. (2012) Habitat filtering and niche differentiation jointly explain species relative abundance within grassland communities along fertility and disturbance gradients. New Phytologist, 196, 497-509. 
Mason, N.W., Mouillot, D., Lee, W.G., \& Wilson, J.B. (2005) Functional richness, functional evenness and functional divergence: the primary components of functional diversity. Oikos, 111(1), 112-118.

Mason, N. W., de Bello, F., Doležal, J., \& Lepš, J. (2011) Niche overlap reveals the effects of competition, disturbance and contrasting assembly processes in experimental grassland communities. Journal of Ecology, 99, 788-796.

Mayfield, M.M., \& Levine, J.M. (2010) Opposing effects of competitive exclusion on the phylogenetic structure of communities. Ecology letters, 13, 1085-1093.

Michalet, R., Brooker, R. W., Cavieres, L.A., et al. (2006) Do biotic interactions shape both sides of the humpedback model of species richness in plant communities? Ecology letters, 9, 767-773.

Mouillot, D., Villéger, S., Scherer-Lorenzen, M., \& Mason, N.W. (2011) Functional structure of biological communities predicts ecosystem multifunctionality. PloS one, 6, e17476.

Pacala, S.W. \& Tilman, D. (1994) Limiting similarity in mechanistic and spatial models of plant competition in heterogeneous environments. American Naturalist, 45, 222-257.

Padilla, F.M., \& Pugnaire, F.I. (2007) Rooting depth and soil moisture control Mediterranean woody seedling survival during drought. Functional Ecology, 21, 489-495.

Pakeman, R.J. (2011) Functional diversity indices reveal the impacts of land use intensification on plant community assembly. Journal of Ecology, 99, 1143-1151.

Pérez-Harguindeguy N., Díaz S., Garnier E.,et al. (2013) New handbook for standardised measurement of plant functional traits worldwide. Australian Journal of Botany, 61, 167-234.

Poole D.K. \& Miller P.C. (1981) The distribution of plant water stress and vegetation characteristics in Southern California chaparral. The American Midland Naturalist, 105, 32-43.

Poorter, L., \& Markesteijn, L. (2008) Seedling traits determine drought tolerance of tropical tree species. Biotropica, 40, 321-331.

Reich, P.B.,Walters,M.B. \& Ellsworth, D.S. (1992) Leaf lifespan in relation to leaf, plant, and stand characteristics among diverse ecosystems. Ecological Monographs 62, 365-392.

Reu, B., Proulx, R., Bohn, K., Dyke, J. G., Kleidon, A., Pavlick, R. \& Schmidtlein, S. (2011) The role of climate and plant functional trade-offs in shaping global biome and biodiversity patterns. Global Ecology and Biogeography, 20, 570-581.

Rosenfeld, J.C. (2002) Functional redundancy in ecology and conservation. Oikos, 98, 156-162.

Shipley, B. (2010) From Plant Traits to Vegetation Structure: Chance and Selection in the Assembly of Ecological Communities. Cambridge University Press, Cambridge, UK.

Šímová, I., Violle, C., Kraft, N. J., et al. (2015) Shifts in trait means and variances in North American tree assemblages: species richness patterns are loosely related to the functional space. Ecography, 38, 649-658.

Stubbs, W.J. \& Bastow Wilson, J. (2004) Evidence for limiting similarity in a sand dune community. Journal of Ecology, 92, 557-567.

Thuiller, W., Lavorel, S., Sykes, M.T., \& Araújo, M.B. (2006) Using niche-based modelling to assess the impact of climate change on tree functional diversity in Europe. Diversity and Distributions, 12, 49-60.

Tilman, D. \& Downing, J.A. (1994) Biodiversity and stability in grasslands. Nature, 367, 363-365.

Trabucco A., \& Zomer RJ. (2009) Global Aridity Index (Global-Aridity) and Global Potential EvapoTranspiration (Global-PET) Geospatial Database. CGIAR Consortium for Spatial Information. Published online, available from the CGIAR-CSI GeoPortal at: http://www.csi.cgiar.org

Violle, C. \& Jiang, L. (2009) Towards a trait-based quantification of species niche. Journal of Plant Ecology, 2 , 87-93.

Violle, C., Reich, P.B., Pacala, S.W., Enquist, B.J., \& Kattge, J. (2014) The emergence and promise of functional biogeography. Proceedings of the National Academy of Sciences, 111, 13690-13696.

Walker, B.H. (1992) Biodiversity and ecological redundancy. Conservation Biology, 6, 18-23.

Woodward, F. I. (1987). Climate and plant distribution. Cambridge University Press.Heywood VH (1995) (ed.). Global Biodiversity Assessment. Cambridge University Press, England.

Wright, I. J., Reich, P. B., Westoby, M., et al. (2004) The worldwide leaf economics spectrum. Nature, 428, 821 $-827$. 
Appendix S1. List of the 74 woody plants species, family, life habit and their presence/absence in the five zones. T, tree; ST, small tree or arborescent shrub; S, shrub.

\begin{tabular}{|c|c|c|c|c|c|c|c|}
\hline Species & Family & $\begin{array}{c}\text { Life } \\
\text { habit }\end{array}$ & $\begin{array}{l}\text { Semi-Arid } \\
\text { Shrubland }\end{array}$ & $\begin{array}{c}\text { Dry } \\
\text { Shrubland }\end{array}$ & $\begin{array}{c}\text { Dry } \\
\text { Forest }\end{array}$ & $\begin{array}{l}\text { Sub-Humid } \\
\text { Forest }\end{array}$ & $\begin{array}{c}\text { Riparian } \\
\text { Forest }\end{array}$ \\
\hline Alnus glutinosa & Betulaceae & $T$ & & & & & $x$ \\
\hline Anthyllis citysoides & Fabaceae & S & $x$ & & & & \\
\hline Anthyllis terniflora & Fabaceae & S & $x$ & & & & \\
\hline Arbutus unedo & Ericaceae & ST & & & $x$ & $x$ & \\
\hline Armeria velutina & Plumbaginaceae & $S$ & & $x$ & & & \\
\hline Artemisia barririeri & Asteraceae & S & $x$ & & & & \\
\hline Atractylis humilis & Asteraceae & S & $x$ & & & & \\
\hline Ballota hirsuta & Lamiaceae & $\mathrm{S}$ & $x$ & & & & \\
\hline Celtis australis & Cannabaceae & $\mathrm{T}$ & & & & & $x$ \\
\hline Cistus albidus & Cistaceae & S & $x$ & & $x$ & & \\
\hline Cistus crispus & Cistaceae & S & & & $x$ & & \\
\hline Cistus ladanifer & Cistaceae & S & & & $x$ & & \\
\hline Cistus libanotis & Cistaceae & $\mathrm{S}$ & & $x$ & & & \\
\hline Cistus monspeliensis & Cistaceae & $\mathrm{s}$ & & & $x$ & & \\
\hline Cistus salvifolius & Cistaceae & S & & & $x$ & $x$ & \\
\hline Coronilla juncea & Fabaceae & $\mathrm{s}$ & $x$ & & & & \\
\hline Crataegus monogina & Rosaceae & ST & & & & $x$ & $x$ \\
\hline Cytisus grandiflorus & Fabaceae & $\mathrm{s}$ & & $x$ & & & \\
\hline Daphne gnidium & Malvaceae & $\mathrm{S}$ & & & $x$ & & \\
\hline Ephedra fragilis & Ephedraceae & $\mathrm{S}$ & $x$ & & & & \\
\hline Erica arborea & Ericaceae & $\mathrm{S}$ & & & & $x$ & \\
\hline Erica scoparia & Ericaceae & s & & $x$ & & & \\
\hline Ficus carica & Moraceae & $\mathrm{T}$ & & & & & $x$ \\
\hline Fraxinus angustifolia & Oleaceae & T & & & & & $x$ \\
\hline Fumana spidula & Violaceae & S & $x$ & & & & \\
\hline Genista hirsuta & Fabaceae & $\mathrm{S}$ & & & $x$ & & \\
\hline Halimium commutatum & Malvaceae & s & & $x$ & & & \\
\hline Halimium halimifolium & Malvaceae & $\mathrm{S}$ & & $x$ & & & \\
\hline Hedera helix & Araliaceae & ST & & & & $x$ & $x$ \\
\hline Helianthemum almeriensis & Malvaceae & $\mathrm{s}$ & $x$ & & & & \\
\hline Helianthemum syriacum & Malvaceae & $\mathrm{S}$ & $x$ & & & & \\
\hline Helichrysum stoechas & Asteraceae & s & $x$ & & & & \\
\hline Helycrissum picardii & Asteraceae & S & & $x$ & & & \\
\hline Hippocrepis scabra & Fabaceae & $\mathrm{S}$ & $x$ & & & & \\
\hline Juniperus phoenicea & Cupressaceae & ST & & $x$ & & & \\
\hline Launaea arborescens & Asteraceae & $\mathrm{s}$ & $x$ & & & & \\
\hline Lavandula multifida & Lamiaceae & $\mathrm{s}$ & $x$ & & & & \\
\hline Lavandula stoechas & Lamiaceae & S & & $x$ & $x$ & & \\
\hline Myrtus communis & Mirtaceae & $\mathrm{S}$ & & & $x$ & & \\
\hline Nerium oleander & Apocynaceae & ST & & & & & $x$ \\
\hline Phlomis fruticosa & Lamiaceae & $\mathrm{S}$ & & & & $x$ & \\
\hline Phlomis purpurea & Lamiaceae & $\mathrm{S}$ & $x$ & & $x$ & & \\
\hline Phyllirea angustifolia & Oleaceae & ST & & & $x$ & & \\
\hline Phyllirea latifolia & Oleaceae & ST & & & & $x$ & $x$ \\
\hline Pinus pinea & Pinnaceae & $T$ & & $x$ & & & \\
\hline Pistacia lentiscus & Anaca rdiaceae & ST & & & $x$ & $x$ & $x$ \\
\hline Pistacia terebinthus & Anaca rdiaceae & ST & & & $x$ & & \\
\hline Populus alba & Salicaceae & $T$ & & & & & $x$ \\
\hline Quecus cocifera & Fagaceae & ST & & & $x$ & & \\
\hline Quercus canariensis & Fagaceae & $T$ & & & & $x$ & \\
\hline Quercus ilex & Fagaceae & ST & & & $x$ & & \\
\hline Quercus suber & Fagaceae & $\mathrm{T}$ & & & & $x$ & \\
\hline Rhamnus alaternus & Rhamnaceae & s & & & & $x$ & \\
\hline Rhamnus lycioides & Rhamnaceae & S & & & & & $x$ \\
\hline Rhododendron ponticum & Ericaceae & S & & & & $x$ & \\
\hline Rosa canina & Rosaceae & $\mathrm{S}$ & & & & & $x$ \\
\hline Rosmarinus officinalis & Lamiaceae & $\mathrm{S}$ & $x$ & $x$ & $x$ & & \\
\hline Rubus ulmifolius & Rosaceae & ST & & & & $x$ & \\
\hline Ruscus aculeatus & Asparagaceae & $\mathrm{S}$ & & & & $x$ & $x$ \\
\hline Salix atrocinerea & Salicaceae & $\mathrm{T}$ & & & & & $x$ \\
\hline Sideritis pusilla & Lamiaceae & $\mathrm{s}$ & $x$ & & & & \\
\hline Smilax aspera & Smilacaceae & ST & & & & & $x$ \\
\hline Staurachantus genistoides & Fabaceae & $\mathrm{s}$ & & $x$ & & & \\
\hline Teucrium charidemi & Lamiaceae & $\mathrm{S}$ & $x$ & & & & \\
\hline Teucrium fruticans & Lamiaceae & $\mathrm{S}$ & & & & & \\
\hline Thymelaea hirsuta & Malvaceae & $\mathrm{s}$ & $x$ & & & & \\
\hline Thymus hyemalis & Lamiaceae & $\mathrm{s}$ & $x$ & & & & \\
\hline Thymus mastichina & Lamiaceae & $\mathrm{s}$ & & $x$ & & & \\
\hline Ulex australis & Fabaceae & $\mathrm{S}$ & & $x$ & & & \\
\hline Ulex parviflorus & Fabaceae & $\mathrm{S}$ & $x$ & & & & \\
\hline Ulmus minor & Ulmaceae & $\mathrm{T}$ & & & & & $x$ \\
\hline Viburnum tinus & Adoxaceae & ST & & & & $x$ & \\
\hline Vitis vinifera & Vitaceae & ST & & & & & $x$ \\
\hline Withania frutescens & Solanaceae & $\mathrm{S}$ & $x$ & & & & \\
\hline
\end{tabular}


Appendix S2. Results of a one-way ANOVA between zones for functional traits. Some traits have been log-transform in order to fulfil ANOVA assumption (*).

\begin{tabular}{|c|c|c|c|c|c|c|c|c|c|c|c|c|c|c|c|c|c|c|c|c|c|c|c|}
\hline \multirow[b]{2}{*}{ Trait } & \multirow[b]{2}{*}{ Units } & \multicolumn{4}{|c|}{ Arid Shr } & \multicolumn{4}{|c|}{ SArid Shr } & \multicolumn{4}{|c|}{ DrySH For } & \multicolumn{4}{|c|}{ Hum For } & \multicolumn{4}{|c|}{ Rip For } & \multirow{2}{*}{1} & \multirow{2}{*}{1} \\
\hline & & Mean & & SE & & Mean & & SE & & Mean & & SE & & Mean & & SE & & hean & & SE & & & \\
\hline Lsize* & $\mathrm{cm}^{2}$ & 1.26 & \pm & 0.28 & $\bar{c}$ & 0.64 & \pm & 0.20 & c & 3.10 & \pm & 2.17 & $\bar{b}$ & 11.8 & \pm & 2.17 & $\bar{a}$ & 26.6 & \pm & 10.6 & $a$ & 23.1 & $<0.001$ \\
\hline SLA* & $\mathrm{m}^{2} \mathrm{~kg}^{-1}$ & 11.27 & \pm & 0.92 & $b c$ & 7.39 & \pm & 0.81 & $\mathrm{~cd}$ & 8.51 & \pm & 0.65 & c & 12.5 & \pm & 0.84 & $a b$ & 17.1 & \pm & 2.0 & $\mathrm{a}$ & 9.1 & $<0.001$ \\
\hline LDMC & $\mathrm{mg} \mathrm{g}^{-1}$ & 0.27 & \pm & 0.017 & $b$ & 0.38 & \pm & 0.01 & $\mathrm{a}$ & 0.41 & \pm & 0.15 & $\mathrm{a}$ & 0.35 & \pm & 0.05 & $a$ & 0.35 & \pm & 0.08 & $\mathrm{a}$ & 11.9 & $<0.001$ \\
\hline WD & $\mathrm{mg} \mathrm{g}^{-1}$ & 0.51 & \pm & 0.02 & $a b$ & 0.53 & \pm & 0.08 & $a b$ & 0.59 & \pm & 0.08 & $\mathrm{a}$ & 0.44 & \pm & 0.1 & $b$ & 0.43 & \pm & 0.11 & $b$ & 6.2 & $<0.001$ \\
\hline SDMC & $\mathrm{g} \mathrm{cm}^{-3}$ & 0.44 & \pm & 0.01 & $\mathrm{~b}$ & 0.46 & \pm & 0.06 & $b$ & 0.51 & \pm & 0.01 & $a$ & 0.41 & \pm & 0.07 & $b$ & 0.41 & \pm & 0.08 & $b$ & 5.9 & $<0.001$ \\
\hline SRL* & $m g g^{-1}$ & 5.16 & \pm & 0.36 & c & 13.4 & \pm & 1.84 & $a b$ & 10.8 & \pm & 0.87 & $\mathrm{~b}$ & 14.3 & \pm & 1.05 & $a$ & 16.1 & \pm & 6.32 & a & 25.4 & $<0.001$ \\
\hline RDMC & $m g g^{-1}$ & 0.34 & \pm & 0.01 & $\mathrm{bc}$ & 0.43 & \pm & 0.01 & $a$ & 0.39 & \pm & 0.01 & $a b$ & 0.36 & \pm & 0.02 & $b$ & 0.3 & \pm & 0.01 & c & .9 & $<0.001$ \\
\hline TMDr & $\mathrm{g} \mathrm{cm}^{-3}$ & 0.58 & \pm & 0.02 & $\mathrm{~b}$ & 0.8 & \pm & 0.04 & $a$ & 0.66 & \pm & 0.02 & $\mathrm{~b}$ & 0.62 & \pm & 0.03 & $\mathrm{~b}$ & 0.57 & \pm & 0.04 & $\mathrm{~b}$ & 7.7 & $<0.001$ \\
\hline LN* & $\mathrm{m}$ & 2.63 & \pm & 0.14 & a & 2.11 & \pm & 0.18 & $\mathrm{bc}$ & 1.77 & \pm & 0.08 & $b c$ & 2.04 & \pm & 0.07 & $\mathrm{bc}$ & 2.47 & \pm & 0.14 & $a b$ & 6.9 & $<0.01$ \\
\hline LChI* & $\mathrm{m}^{2}$ & 1066.4 & \pm & 94.8 & $\mathrm{~b}$ & 666 & \pm & 72.4 & c & 910.6 & \pm & 68.2 & $\mathrm{~b}$ & 1873 & \pm & 180.4 & $a$ & 2085.6 & \pm & 203.6 & $a$ & 20.7 & $<0.001$ \\
\hline$\delta^{13} \mathrm{C}$ & $\%$ & -28.6 & \pm & 0.3 & & -27.6 & \pm & 0.5 & & -27.6 & \pm & 0.28 & & -28.9 & \pm & 0.28 & & -28.4 & \pm & 0.15 & & 3 & ns \\
\hline Pheight* & $\mu g^{-1}$ & 0.61 & \pm & 0.67 & c & 0.87 & \pm & 0.13 & c & 1.91 & \pm & 0.27 & $b$ & 4.17 & \pm & 0.77 & $a$ & 5.52 & \pm & 0.8 & $\mathrm{a}$ & 35.5 & $<0.001$ \\
\hline Pcover* & $\%$ & 0.83 & \pm & 0.16 & $\mathrm{~d}$ & 0.78 & \pm & 0.21 & $\mathrm{~d}$ & 4.39 & \pm & 1.68 & c & 12.1 & \pm & 4.27 & $\mathrm{~b}$ & 22.6 & \pm & 4.36 & a & 28.7 & $<0.001$ \\
\hline
\end{tabular}


Appendix S3. Estimated three-dimensional hypervolumes of the five zones for each independent plant dimension: (A) Leaf morphology, (B) Root morphology and (C) Leaf chemical. The left-bottom of each box shows the fractional overlap (Sørensen index) among hypervolumes of each zone

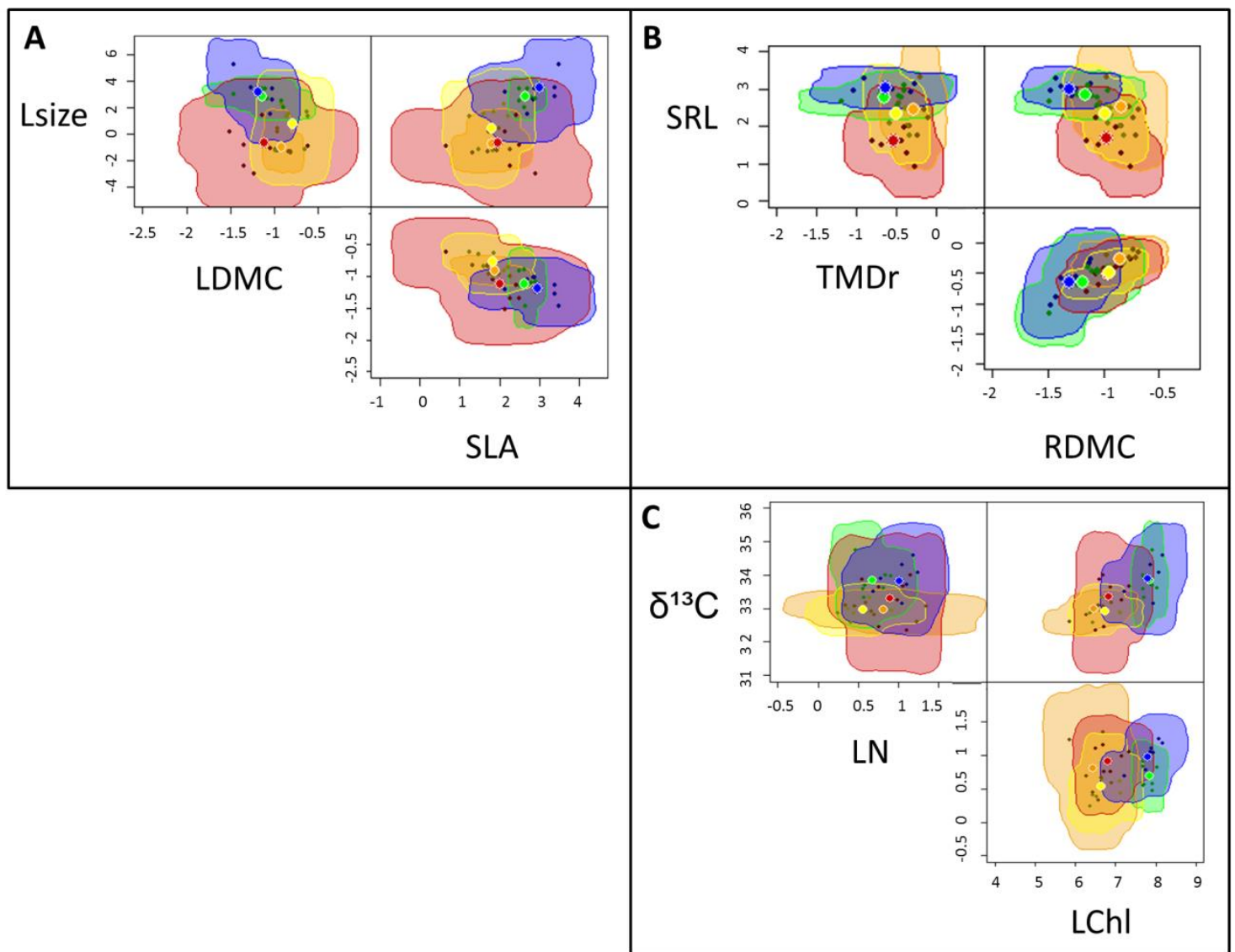




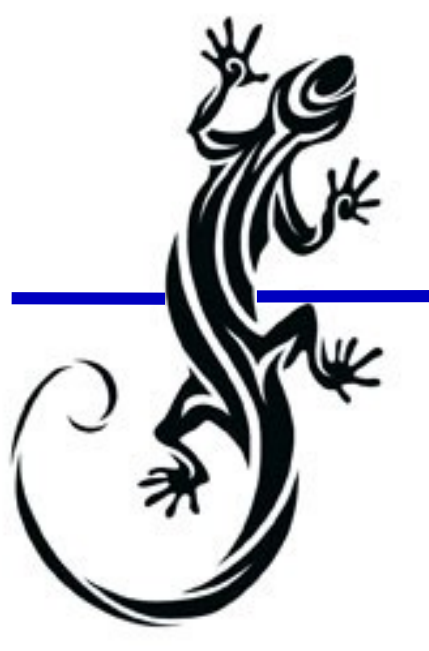

\section{Capítulo 6}

The importance of functional

diversity in the stability of

Mediterranean shrubland communities after

the impact of extreme climatic events

"Las buenas fuentes se conocen en las grandes sequias: los buenos amigas.
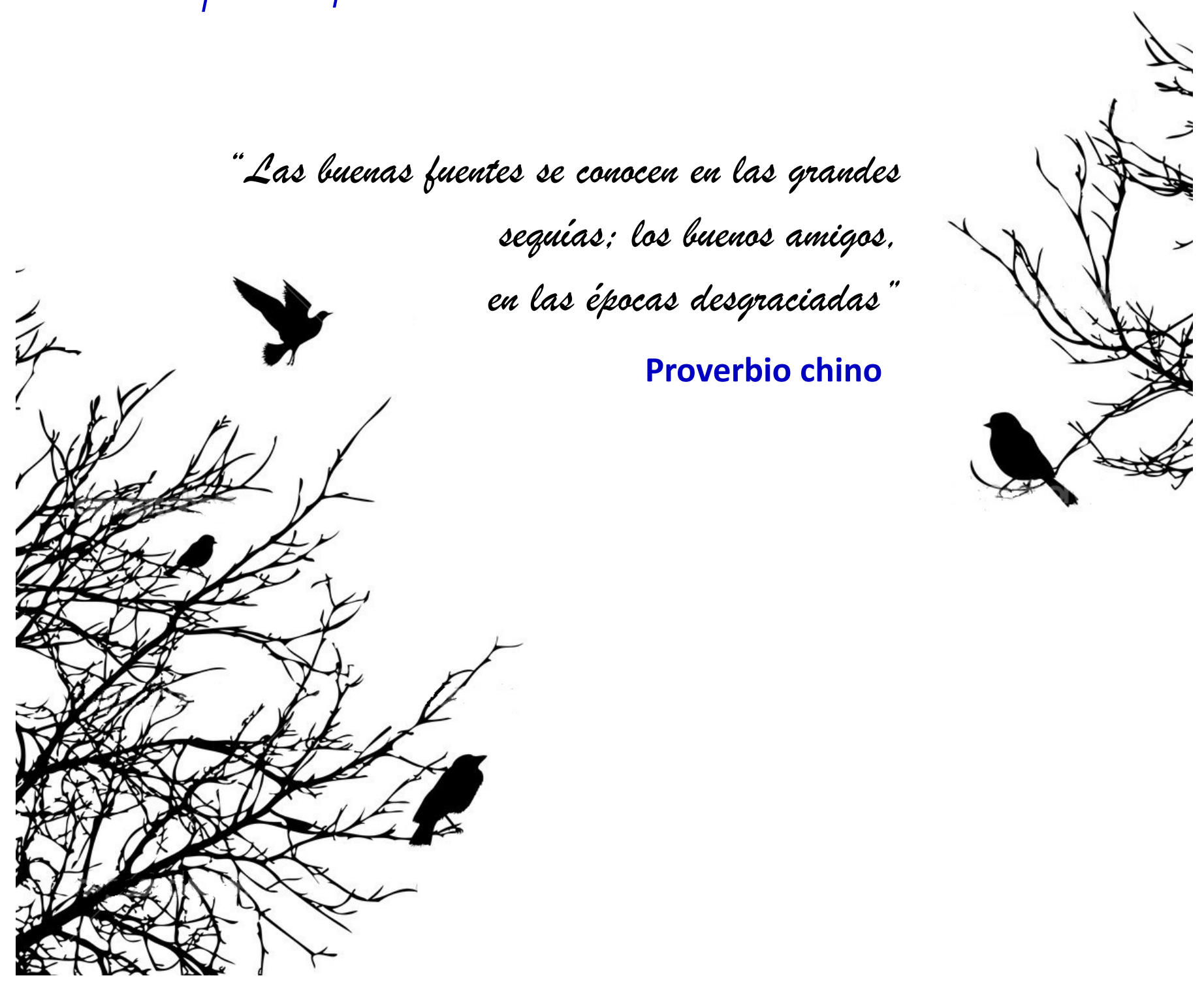

Proverbio chino 



\title{
The importance of functional diversity in the stability of Mediterranean
}

\section{shrubland communities after the impact of extreme climatic events}

\author{
Enrique G. de la Rival ${ }^{1}$,Francisco Lloret ${ }^{2,3}$, Ignacio M. Pérez-Ramos ${ }^{4}$, Teodoro Marañón ${ }^{4}$, Sandra Saura- \\ Mas $^{2,3}$, Ricardo Díaz-Delgado ${ }^{5}$, Rafael Villar ${ }^{1}$ \\ ${ }^{1}$ Area de Ecología, Facultad de Ciencias, Universidad de Cordoba. 14071 Cordoba, Spain; ${ }^{2}$ CREAF 08193, Cerdanyola del Vallès, \\ Barcelona, Spain; ${ }^{3}$ Unitat d'Ecologia, Dept. Biologia Animal, Biologia Vegetal i Ecologia, Universitat Autònoma Barcelona, Edifici C, \\ Campus UAB, 08193, Cerdanyola del Vallès, Barcelona, Spain; ${ }^{4}$ IRNAS, CSIC, Av. Reina Mercedes 10, P.O. Box 1052. 41080 Sevilla, \\ Spain; ${ }^{5}$ Estación Biológica de Doñana, CSIC. c/ Americo Vespucio, s/n, Isla de la Cartuja. 41092 Sevilla, Spain
}

\begin{abstract}
Extreme climatic events may have important consequences for plant community structure and composition. In 2005, a severe drought together with a cold winter promoted extensive damage and mortality in shrubland communities of southwest Spain (Doñana National Park). Here, we aim to identify the mechanisms underlying community stability (resistance and resilience) in response to this extreme climatic event, considering changes in the functional structure of these communities.
\end{abstract}

\section{Important Findings}

\section{Methods}

We used a trait-based approach, quantifying variations in 10 functional traits at the community level (community weighted means, CWM) and the functional diversity (functional richness, evenness and divergence) in 18 plots at three different times: predating the climatic event (estimated from the sum of the live and dead volume of each species in 2007), and two and eight years after the 2005 episode. We also quantified the differences in functional traits and functional diversity between adult and recruit stages, which allowed us to better understand the contribution of the recruitment to the maintenance of the functional structure and diversity of the community.
Communities with higher functional divergence before the climatic event maintained nearly constant their levels of functional divergence eight years after, but they were more prone to changes in species composition. Community resistance in terms of vegetation cover was positively correlated with root dry matter content, whereas community resilience was positively correlated with leaf chlorophyll. We also found that some values (weighted means) of functional community traits (such as root dry matter content and leaf chlorophyll) had increased two years after the event, returning to the pre-event conditions after eight years. In addition, there was hardly any establishment of new species in the community and the recruits did not make substantial differences to the community functional structure. Only seed mass differed significantly between the adult and seedling stages. In summary, the extreme climatic event induced rapid vegetation changes, modifying several functional properties of the community, but, in spite of the occurrence of changes in species composition, a rapid convergence of these shrubland communities took place due to the replacement of species with functional redundancy, thus recovering the initial conditions and supporting the existence of strong mechanisms of functional resilience.

Keywords: climate change $\bullet$ drought $\bullet$ functional trait recruitment $\bullet$ resilience $\bullet$ resistance.

\section{INTRODUCTION}

The occurrence of extreme climatic events, resulting from a high variability in temperature and precipitation, has received increased attention in the last few years (Easterling et al. 2000; Kreyling et al. 2008; Jentsch et al. 2011). The expected increase in climatic variability would involve more frequent extreme climatic events in the near future (IPCC 2013), in spite of the uncertainty when considering small temporal and spatial scales (Kao and Ganguly 2011). These extreme climatic events are likely to trigger ecosystem disturbances that may affect plant species composition (Lloret and Granzow-de la Cerda 2013) and, thus, the functional attributes of communities.

After climate event disturbances, rapid changes in plant communities can be hypothesised as a result of increased differential mortality in some species and their potential replacement by other species better adapted to the new climatic conditions (Lloret 2012). Alternatively, species can be replaced by others with similar functional attributes ('functional redundancy' hypothesis, e.g. Naeem 1998). Most research has focused on analysing the effect of extreme climatic events on: i) variations in species and individual responses, mainly trees (Gillespie and Loik 2004; Breshears et al. 2005; Sangüesa-Barreda et al. 2012); ii) changes in productivity and species composition (Sternberg et al. 1999; Grime et al. 2000; White et al. 2000; Jentsch et al. 2011); or iii) recruitment processes (Lloret et al. 2005; Lloret and Granzow-de la Cerda 2013). Nonetheless, there is a lack of studies that evaluate the impact of climatic events on the functional structure of communities (but see Polley et al. 2013; Majekova et al. 2014) and, especially, that consider also different life-history stages (e.g. adult and recruitment stages). 
The ecosystem response to disturbances (such as an extreme climatic event) comprises two main aspects related to stability: resistance, which can be defined as the tendency of the ecosystem to remain in a reference state despite perturbation; and resilience, which can be described as the ability of a particular ecosystem or community to return to a reference state prior to the disturbance (Potts et al. 2006 and references therein). At the community level, these processes are determined by the balance through time between demographic processes (recruitment and mortality rates) of the different coexisting species (Lloret et al. 2012). These processes may produce temporary changes in vegetation, although in many cases plant populations exhibit remarkable inertia (Lloret and Zedler 2009; Lloret et al. 2012).

The effects of climatic events on plant community stability (resistance and resilience) can be analysed also by exploring temporal changes in the functional structure and diversity of the community (Díaz and Cabido 2001; Hooper et al. 2005). Two widely recognised and complementary indicators can be used to explain how species traits within a community may influence these ecosystem properties (de Bello et al. 2010): i) community weighted means (CWM), based on the biomass ratio hypothesis (Grime 1998), where the mean trait values of the species present in a community are weighted by their relative abundances (Garnier et al. 2004), and ii) functional diversity, defined as the degree to which coexisting species vary in terms of their functional traits (Weiher 2010). More diverse communities, in terms of species or functional groups, are theoretically expected to be more resistant and resilient against environmental perturbations (Yachi and Loreau 1999; Grime 2001), as has been reported for temperate grasslands (Tilman et al. 2006; van Ruijven and Berendse 2010). Although more diverse communities generally have higher stability (Díaz and Cabido 2001; Bastolla et al. 2009), there is considerable uncertainty about which components of diversity (i.e. species richness, functional group richness or the presence of some key species) determine this relationship (Kreyling et al. 2011). This conceptual framework has stimulated research aiming to functionally interpret the relationships between community composition, environmental changes and ecosystem processes (Lavorel et al. 2008; Villéger et al. 2010; Mason et al. 2012; Dias et al. 2013). However, the role of functional diversity in the vegetation responses to extreme climatic events remains poorly understood.

Among the extreme climatic events, severe drought and anomalous temperatures can have great effects on vegetation composition and productivity (Breshears et al. 2005). Water availability is a key factor for plant survival and growth in arid and semi-arid regions (Padilla and Pugnaire 2007). Therefore, functional traits related to drought resistance or resilience may be related to demographic performance after disturbance (Saura-Mas et al. 2009) and thus contribute to the species response to climatic events. In this sense, several functional traits have been used to assess the level of drought resistance shown by plants: for example, those related with water use efficiency (represented by carbon isotopic discrimination, $\delta^{13} \mathrm{C}$; Farquhar et al. 1982) or those associated with a more conservative resource-use strategy, such as low values of specific leaf and/or root area or higher tissue dry matter content (Poorter and Markejstein 2008; Hernández et al. 2010; Pérez-Ramos et al. 2013). In addition, some traits related with drought resilience may help to understand community recovery after extreme climatic episodes (Lloret et al. 2016), such as regenerative traits related to plant establishment (e.g. higher seed mass; Pérez-Ramos et al. 2010), or higher photosynthetic potential (e.g. higher leaf nitrogen and chlorophyll concentrations) - which allows plants to reach high rates of growth and foliage production after drought (Eamus and Prior 2001).

In 2005 two simultaneous extreme climatic events, a severe drought and a very cold winter, took place in Doñana National Park (southwest Spain), and were followed by extensive shrubland damage and mortality (Díaz-Delgado 2006; Díaz-Delgado et al. 2014, see aerial photographs in Supplementary Fig. S1). These climatic events could have promoted differential die-off among coexisting species, modifying the functional structure of the community. Consequently, we hypothesise that these events could have had a filtering effect - increasing the functional homogeneity (favouring tolerant species) during a first stage and recovering the functional heterogeneity afterwards.

In this study, our main objective was to identify possible mechanisms of stability (resistance and resilience) of shrubland communities following an extreme climatic event of severe drought and a cold winter, using a trait-based approach. For this purpose, we explored temporal changes in the community functional structure: trait composition at the community level and functional diversity (of both adults and recruits) in response to those climatic events. For this, we surveyed the species composition after the event and some years later, estimating the pre-event composition by adding together the live and dead volume of each species. We also measured a broad set of functional traits (including leaf, stem, root, seed and whole-plant traits) that could be related with plant survival after drought and/or low temperatures. Then, we quantified relevant indexes of functional diversity. Specifically, we studied three main topics with the final aim of answering the following questions: i) regarding changes in the functional diversity of plant communities: was there a decrease in functional diversity after the climatic event? Were communities harbouring higher initial functional diversity more resistant or resilient to these climatic disturbances? ii) Regarding changes in community functional traits: can we predict the functional traits contributing most to the community resistance and resilience to extreme climatic events? Which functional traits were affected (positively or negatively) by the climatic event? And iii) regarding the regeneration patterns: was the community functional diversity of the plants at the recruit stage a reflection of the adult stage? Alternatively, are they biased towards certain functional traits associated with colonisers after disturbance? 


\section{MATERIAL AND METHODS}

\section{Study area}

The study was carried out in Doñana (southwest Spain), which was declared a National Park (1969), Biosphere Reserve (1981) and World Heritage site (1994). The climate is Mediterranean-type with an oceanic influence; mean annual rainfall is $560 \mathrm{~mm}$, albeit with considerable inter-annual variations, ranging from $<300 \mathrm{~mm}$ in dry years to $1000 \mathrm{~mm}$ in extremely wet years. The mean annual temperature is $16.5^{\circ} \mathrm{C}$, with mean temperatures of $24.7^{\circ} \mathrm{C}$ in the hottest month (July) and 10.0 ${ }^{\circ} \mathrm{C}$ in the coldest month (January). According to the Global-Aridity index (Trabucco and Zomer 2009) the study area is classified as semi-arid. The site is ca. $3 \mathrm{~km}$ from the Atlantic Ocean, on a large Quaternary eolic dune field that was stabilised during the Holocene (Muñoz-Reinoso and Garcia-Novo 2005). The vegetation of the Doñana paleodunes is a mosaic of wetlands and extensive shrublands, with locally dense stands of juniper (Juniperus phoenicea ssp. turbinata) that are often mixed with Pinus pinea (originally planted), remnant individuals of Quercus suber, small patches of Pistacia lentiscus and grassland areas dominated by annual plants. Specifically, the study was carried out in a xeric shrubland type locally known as 'monte blanco', with a large abundance of shrub species such as Cistus libanotis, Halimium halimifolium, Helichrysum pichardii, Lavandula stoechas, Rosmarinus officinalis, Thymus mastichina and Ulex australis. The 'monte blanco' is considered to be a seral stage of juniper woodlands (García-Murillo and Sousa-Martín 1999). The abundance of herbaceous species, in terms of plant biomass, is marginal in the 'monte blanco' shrublands; therefore, they were not considered in this study.

An event of extreme drought occurred during the hydrological year 2004-2005, when total rainfall only reached $173 \mathrm{~mm}(69 \%$ less than the average). This drought was combined with a very cold winter, with absolute minimum temperatures of $-5{ }^{\circ} \mathrm{C}$ and $-4{ }^{\circ} \mathrm{C}$ and mean minimum temperatures of $1.1^{\circ} \mathrm{C}$ and $0.9^{\circ} \mathrm{C}$ for January and February, respectively, which were much lower than the mean minimum values registered for the last 35 years $\left(4.7{ }^{\circ} \mathrm{C}\right.$ for January and $5.8{ }^{\circ} \mathrm{C}$ for February; see Supplementary Fig. S2). This climatic event was rapidly followed by a general die-off of green tissue on the dominant shrubland vegetation that reached $75 \%$ of the plant cover in some stands (Lloret et al. 2015) and produced a significant drop in the Normalized Difference Vegetation Index (NDVI) during the year of the event (Díaz-Delgado 2006; Supplementary Figs. S1 and S3). In the years following the event, the annual rainfall ranged from $468 \mathrm{~mm}$ (in the 20052006 hydrological year) to $713 \mathrm{~mm}$ (in 2010-2011).

Sampling of vegetation and estimation of resistance and resilience

Eighteen permanent plots of $25 \mathrm{~m}^{2}(5 \times 5 \mathrm{~m})$ were established in November 2007 (two years after the drought). The reliability of surveying the impact on the vegetation two years after the extreme climatic event was supported by NDVI values obtained from Landsat imagery for $30 \times 30 \mathrm{~m}$ pixels $(\mathrm{n}=21)$ corresponding to the locations of the sampled plots. The comparative analyses of these images between different years did not detect significant differences in plant canopy greenness between November 2005 and 2007, while there was a significant decrease in 2005 in relation to the previous years as well as a slight recovery after 2007 (see Supplementary Fig. S3).

The plots were separated by at least $50 \mathrm{~m}$ from each other and were distributed in three sites (six plots per site) within an area of approximately $10 \mathrm{~km}^{2}$ : Raposo ( $37^{\circ} 0^{\prime} 2^{\prime \prime}$, W $6^{\circ} 30^{\prime} 20^{\prime \prime}$ ), Ojillo ( $36^{\circ} 59^{\prime} 40^{\prime \prime}, \mathrm{W}$ $6^{\circ} 30^{\prime} 50^{\prime \prime}$ ) and Marqués ( $\mathrm{N} \mathrm{37^{ \circ }} 0^{\prime} 45^{\prime \prime}$, W 6 $6^{\circ} 31^{\prime} 50^{\prime \prime}$ ). The three sites slightly differed in their elevation with respect to the dune field (Raposo was located at the bottom, at $18 \mathrm{~m}$ a.s.l., Marqués on the top, at $30 \mathrm{~m}$ a.s.1. and Ojillo in an intermediate position, close to the top, at $21 \mathrm{~m}$ a.s.l), which likely resulted in potential differences in their height above the water table (García et al. 2014).

The composition and abundance of the shrub species (see Supplementary Table S1) were measured in each plot by estimation of the volume (from the product of the height and mean canopy diameter), as determined by the extreme of branches, excluding leaves and recent shoots of all living and dead adult shrubs. This procedure made the estimated volume comparable for living and dead plants, as shown by the lack of significant difference in the volume between dead and living individuals for all species ( $\mathrm{t}$-values ranging from 0.08 to $1.79, P>0.05$ in all cases). The only exception was the small-sized Thymus mastichina, for which the dead plants were smaller $(\mathrm{t}=3.18, P=$ $0.004)$; however, this species contributed little to the overall community due to its low abundance. Dead individuals were identified to the species level by their morphological traits (bark, branch ramification, dry leaves on the ground). We ensured that plants considered as dead had recently lost their foliage (presumably as a consequence of the recent climatic event) by only including plants having branches with thin tips and non -decomposed leaves on the ground beneath the plant canopy, while excluding old stumps and plants constituted only by shoots without thin tips on the branches. The species relative abundance per plot two years after the event (named hereafter " +2 years") was calculated as the live volume in the 2007 survey relative to the sum of the live volume of all species.

The species relative abundance per plot previous to the climatic event (named "pre-event") was calculated as the sum of the live and dead volume of 2007 of each species relative to the sum of the live and dead volume of 2007 for all species. This assumption was supported by the fact that: 1) plants considered as dead were recently defoliated, as indicated by the presence of non-decomposed leaves on the ground beneath plant canopies, as well as by the presence of standing thin branches on plants; 2) there was no decrease in the volume of plants considered as dead, in comparison to 
living plants, as explained in detail above; (3) the increase in the green parts of living plants due to regrowth in 2007 can be considered negligible, as supported by non-significant differences in NDVI measurements between 2005 and 2007 (more details in Supplementary Fig. S3). In June 2013 (8 years after the event; named "+8 years"), we measured again the plant species composition and relative abundance of all shrub species (from their plant volumes).

We consider that the 2007 survey - two years after the event - is a valuable measure of the vegetation response to the climatic episode. Although our estimation of the resistance to the 2005 event merges the damage suffered during that period with delayed mortality (Lloret and López-Soria 1993) and fast recovery until 2007, we consider that these two later effects were relatively low and compensated each other. In fact, in disturbance studies it is recommendable to evaluate the impact of the extreme climatic event considering a short lag after the event, because this allows integration of the delayed decay and regrowth directly related to the studied event.

All these measurements were performed with the main aim of determining the community resistance and resilience after the extreme climatic events. The resistance index (Rt-cover) was defined for each plot as the state of the vegetation two years after the climatic event relative to the pre-event state (Lloret et al. 2011). It was calculated as the sum of the resistance of each species $i$, estimated as $\left[\left(\mathrm{V}_{i+2}\right.\right.$ years $-\mathrm{V}_{i}$ pre-event $) / \mathrm{V}_{i \text { pre- }}$ event], for all the species of the community, $\mathrm{V}_{i}$ being the volume estimated for species $i$ in a particular time period.

Similarly, the resilience index (Rs-cover) was estimated for each plot as the relative recovery rate of the vegetation eight years after the climatic event. It was calculated as the sum of the resilience of each species $i$, estimated as $\left[\left(\mathrm{V}_{i+8 \text { years }}-\mathrm{V}_{i \text { pre-event }}\right) / \mathrm{V}_{i \text { pre-event }}\right]$, for all the species of the community, $\mathrm{V}_{i}$ being the volume estimated for species $i$ in a particular time period.

We estimated also the resistance and resilience of the species composition (Rt-comp and Rs-comp, respectively), defined as the temporal changes in species composition and abundance (Kreyling et al. 2011). They were quantified by using the similarity quantitative index (Bray and Curtis 1957, see Faith et al. 1987) between the values measured pre-event and two years after the episode [Rt-comp; $\left(\Sigma \mid \mathrm{V}_{i}\right.$ pre-event $-\mathrm{V}_{i+2}$ years $\left.\mid\right) /$ $\left(\Sigma \mid \mathrm{V}_{i \text { pre-event }}+\mathrm{V}_{i+2}\right.$ years $\left.\left.\mid\right)\right]$ as well as between the preevent conditions and eight years after the climatic episode [Rs-comp; $\left(\Sigma\left|\mathrm{V}_{i \text { pre-event }}-\mathrm{V}_{i+8 \text { years }}\right|\right) /\left(\Sigma \mid \mathrm{V}_{i \text { pre-event }}+\mathrm{V}_{i}\right.$ +8 years $\mid)]$.

The recruitment of one-year-old seedlings was estimated in November 2007 by recording all the seedlings of shrub species that emerged within each of the 18 plots. The existence of cotyledon scars was considered as evidence that they had recently emerged after the extreme climatic episode. In June 2013, we recorded all juveniles of these shrub species; that is, plants more than one year-old but which had not reached the reproductive stage.

\section{Measurement of plant traits}

In late spring 2013, during the peak of plant growth, healthy adults of 16 species were randomly selected (outside the plots, to avoid disruption of the vegetation monitoring) for the measurement of eight aboveground and two belowground functional traits related with morphology, physiology, chemical composition and reproduction (Table 1). The species were selected according to their abundance in the community (Table $\mathrm{S} 1)$ and, thereby, their potential relevance to the process of community assembly (Garnier et al. 2004; Carlucci et al. 2012; Pérez-Ramos et al. 2012). All trait measurements were carried out according to the criteria and methodology defined by Pérez-Harguindeguy et al. (2013); chlorophyll concentration was measured by the Wintermans \& de Mons method (1965). For more methodological details, see de la Riva et al. (2015).

Aboveground functional traits.- Plant height (Phg) measurements were made on 10 individuals per species. Leaf and stem traits - specific leaf area (SLA; leaf area per unit of leaf dry mass), leaf dry matter content (LDMC; leaf dry mass per unit of leaf watersaturated fresh mass; $\mathrm{mg} \mathrm{g}^{-1}$ ), leaf nitrogen concentration (LNC; \%), leaf chlorophyll (LChl; concentration of chlorophyll per unit of fresh leaf mass; $\mu \mathrm{g} \mathrm{g}^{-1}$ ) and stem dry matter content (SDMC; stem dry mass per unit of stem water-saturated fresh mass; $\mathrm{mg} \mathrm{g}^{-1}$ ) - were measured in six individuals per species. A mixture of leaves from six different individuals was collected for measurement, at the species level, of the carbon isotopic ratio $\left(\delta^{13} \mathrm{C} ; \%\right)$, a trait directly related with plant water use efficiency (Farquhar et al. 1982). The average seed mass $\left(\mathrm{S}_{\text {mass }}\right)$ for each species was compiled from a local data-set (Cordoba Botanical Gardens).

Belowground functional traits.- The roots of four individuals per species were sampled by excavating the first $20-30 \mathrm{~cm}$ of the soil layer near to each plant basal stem. We selected this specific soil depth based on other studies of Mediterranean woody vegetation in Doñana National Park (Martínez et al. 1998) that demonstrated that the largest fraction $(70 \%)$ of fine roots appears in the first $25 \mathrm{~cm}$ of soil depth. These root samples were used to measure two belowground traits of fine roots $(<2 \mathrm{~mm}$ in diameter $)$ related to water and nutrient uptake (Jackson et al. 1997): specific root area (SRA, root area per unit of root dry mass) and root dry matter content (RDMC, root dry mass per unit of root water-saturated fresh mass). These data were obtained by analysing the scanned root samples with WinRHIZO 2009 (Regent Instruments Inc., Quebec, Canada) and weighing the root water-saturated and dry masses.

\section{Measurement of community variables}

The community weighted means (CWM) for each trait and community sample were calculated as $\sum \mathrm{P}_{\mathrm{i}} \times$ Trait $_{\mathrm{i}}$, where $P_{i}$ is the relative abundance of species " $i$ " in the community sample and Trait ${ }_{i}$ is the average trait value obtained for species "i”" (Garnier et al. 2004). 
Table 1. Studied functional traits, their abbreviations, units and their main role in plant functioning.

\begin{tabular}{lccl}
\hline \multicolumn{1}{c}{ Trait } & Abbreviation & Unit & Functional role \\
\hline Specific leaf area & SLA & $\mathrm{m}^{2} \mathrm{~kg}^{-1}$ & Light capture and growth rate \\
Leaf dry matter content & LDMC & $\mathrm{mg} \mathrm{g}^{-1}$ & Physical resistance and stress tolerance \\
Stem dry matter content & SDMC & $\mathrm{mg} \mathrm{g}^{-1}$ & Resistant to physical hazards \\
Specific root area & $\mathrm{SRA}$ & $\mathrm{m}^{2} \mathrm{~kg}^{-1}$ & Water and nutrients acquisition \\
Root dry matter content & $\mathrm{RDMC}$ & $\mathrm{mg} \mathrm{g}^{-1}$ & Resistant to physical hazards \\
Leaf nitrogen concentration & $\mathrm{LN}$ & $\%$ & Light capture and photosynthetic rate \\
Leaf chlorophyll & $\mathrm{LChl}$ & $\mu \mathrm{g} \mathrm{g}^{-1}$ & Light capture and photosynthetic rate \\
Isotopic carbon fraction & $\delta^{13} \mathrm{C}$ & $\%$ & Gas exchange and water-use efficiency \\
Plant height & Phg & $\mathrm{m}$ & Light capture, above-ground competition, dispersal distance \\
Seed mass & Smass & $\mathrm{mg}$ & Dispersal capability and seedling survivorship \\
\hline
\end{tabular}

1 Based on fresh mass

The functional diversity of each community sample was summarised by means of three different and complementary indexes: functional richness $\left(\mathrm{F}_{\text {Rich }}\right)$, which is determined by species occurrence (i.e. independently of their abundances) and reflects the amount (the difference between the maximum and minimum values) of functional trait variability in a given community, reflecting how much of the niche space is occupied by the species present; functional evenness $\left(\mathrm{F}_{\mathrm{Eve}}\right)$, which quantifies the evenness of abundance distribution across species trait values, measuring the regularity of spacing between species along a functional trait gradient and evenness in the distribution of abundance across species; and functional divergence $\left(\mathrm{F}_{\text {Div }}\right)$, which captures the degree of divergence in the abundance distribution of species functional traits and represents how abundance is spread along a functional trait axis, being low when the functional traits of the most abundant species are close to the centre of the functional trait range (for more details see Mason et al. 2005 and Villéger et al. 2008). These independent metrics express different facets of functional diversity by which the community affects ecosystem processes through the functional traits of its species (Mason et al. 2005; Mouchet et al. 2010). In addition, these indexes may reveal the impact of perturbations, such as climatic changes, on community composition and functioning (Villéger et al. 2010). For the purpose of estimating functional diversity, the species occurrence and abundance were estimated from measurements of plant volumes at each sampling time (pre-event, +2 years, +8 years).

\section{Data analyses}

To understand the multidimensional relationships among functional traits and detect a possible redundancy, we conducted exploratory principal components analysis (PCA) based on a correlation matrix of the 10 functional traits in the 16 species sampled. Seed mass $\left(\mathrm{S}_{\text {mass }}\right)$ was log-transformed prior to the analyses to fulfil assumptions of normality.

To explore the influence of the initial functional diversity on community resistance and resilience after the event we conducted two complementary analyses. First, we explored the relationships between the preevent $\mathrm{FD}$ indexes $\left(\mathrm{F}_{\text {Rich }}, \mathrm{F}_{\text {Eve }}\right.$ and $\left.\mathrm{F}_{\text {Div }}\right)$ and the different indexes of community resistance and resilience in order to test our initial hypothesis that communities harbouring higher initial functional diversity are more resistant or resilient to a climatic disturbance. Second, we explored the relationships between each functional diversity index in the pre-event and +8 years surveys, to determine if the functional diversity remains constant or not with time. In addition, we tested whether the resistance and resilience of the community were related with certain initial community functional traits (pre-event CWMs). All these tests were conducted with linear mixed models, considering the predictor variable as the fixed effect and site as the random effect.

Temporal changes in the community functional structure were analysed by using one-way repeated measures ANOVA. Differences between sites (six plots per site) and with time (pre-event, +2 years, +8 years) for each of the 10 community functional traits (CWM) and the three functional diversity indexes were tested. Planned comparisons (Least Significant Difference, LSD) were used to test, post-hoc, for differences implicit in the experimental design (Sokal and Rohlf 1995). The probability values of within-subject factors were analysed with Wilk's lambda multivariate test.

In order to determine the differences in the functional traits and FD indexes between the communities of adults and recruits, we performed a stepwise discriminant analysis for the different surveys, with community functional traits and FD indexes used as independent variables and the groups of adults $(+2$ years and +8 years surveys) and recruits $(+2$ years seedlings, +8 years juveniles) to be discriminated. In these analyses, the species abundances of adults and recruits were estimated from the number of individuals per plot. This analysis allows us to understand the contribution of the recruitment to the maintenance of the functional structure and diversity of the community.

The PCA and linear mixed model analyses were conducted in the $\mathrm{R} 2 \cdot 10 \cdot 0$ statistical platform (R Development Core Team 2011), using the packages 'FactoMiner' (Lê et al. 2008) and 'nlme' (Pinheiro et al. 2015). The package 'FD' (Laliberté et al. 2010) was used to calculate the three functional diversity indexes considered in this study. The repeated measures ANOVA and discriminant analysis were performed with 
SPSS 17.0 (SPSS, Chicago, Illinois, USA).

\section{RESULTS}

The PCA analysis showed a high dispersion of the factors (functional traits) along the first and second axes (Supplementary Fig. S4), indicating a low redundancy (i.e., a low number of significant correlations) among the traits. Although chlorophyll (LChl) and stem dry matter content (SDMC) showed a high correlation (Supplementary Fig. S4), both traits were maintained in the analysis of functional diversity because correlation between traits that do not have a functional link a priori may be considered a relevant aspect of species distribution in the functional trait space (Villéger et al. 2008). The traits related to water-use efficiency $\left(\delta^{13} \mathrm{C}\right)$, reproductive effort $\left(\mathrm{S}_{\text {mass }}\right)$, light capture $(\mathrm{Phg})$ and specific leaf area (SLA, in the opposite direction) exhibited the highest (absolute) scores for the first principal component, which accounted for $32 \%$ of the total variance. The second principal component (explaining $26 \%$ of the total variance) was related to the dry matter content of the different organs (LDMC, RDMC and SDMC) and to chlorophyll (LChl), while specific root area (SRA) was on the opposite extreme of the axis (Supplementary Fig. S4).

The functional richness $\left(\mathrm{F}_{\text {Rich }}\right)$ decreased after the event and subsequently increased to attain values similar to those in the pre-event conditions (Fig. 1), while functional evenness $\left(\mathrm{F}_{\mathrm{Eve}}\right)$ and functional divergence $\left(\mathrm{F}_{\text {Div }}\right)$ did not change significantly with time (Supplementary Table $\mathrm{S} 2$ ). In addition, $\mathrm{F}_{\text {Div }}$ and $\mathrm{F}_{\text {Rich }}$ in the +2 years and +8 years surveys showed positive relationships with their respective pre-event values $(P<0.05$; Fig. 2a), indicating that plots with more functional diversity remained as the most functionally diverse after the climatic event. The $\mathrm{F}_{\text {Div }}$ of the pre-event communities was negatively related with the resilience composition (Rs-comp) $(P<0.05$; Fig. $2 b)$, meaning that the most functionally divergent communities exhibited the most significant changes in species composition in response to the climatic event. However, none of the $\mathrm{FD}$ indexes $\left(\mathrm{F}_{\text {Rich }}, \mathrm{F}_{\text {Eve }}\right.$ and $\left.\mathrm{F}_{\text {Div }}\right)$ were significantly related to community resistance and resilience at the cover level or to Rt-comp (data not shown).

The resistance (Rt-cover) of the communities to the climatic event ranged from -0.88 to -0.11 and was related positively to $\mathrm{RDMC}_{\mathrm{CWM}}(P<0.05$; Fig. 3a) and $\mathrm{SDMC}_{\mathrm{CWM}}$ (marginally significant) and negatively to $\mathrm{SRA}_{\mathrm{CWM}}(P<0.05$; Fig. 3b). On the other hand, the resilience (Rs-cover) of the communities to the climatic event (after 8 years) ranged from -0.83 to 2.13 and was related positively to $\mathrm{LChl}_{\mathrm{CWM}}(P<0.05$; Fig. $3 \mathrm{c})$.

Our results indicate that there were several significant changes in the community functional traits (3 out of 10 traits) with time, independent of the site (see Supplementary Table S2). The community-weighted values of three traits $\left(\mathrm{LChl}_{\mathrm{CWM}}, \mathrm{RDMC}_{\mathrm{CWM}}\right.$ and $\mathrm{Phg}_{\mathrm{CWM}}$ 'marginally significant') increased after the event ( +2 years) but returned to pre-event values in the +8 years survey (Fig. 4). The community values (weighted means) of seed mass ( $\left.\mathrm{S}_{\text {mass }} \mathrm{CwM}\right)$ increased over time, with a significant change between pre-event and +8 years (Fig. $4 c)$.

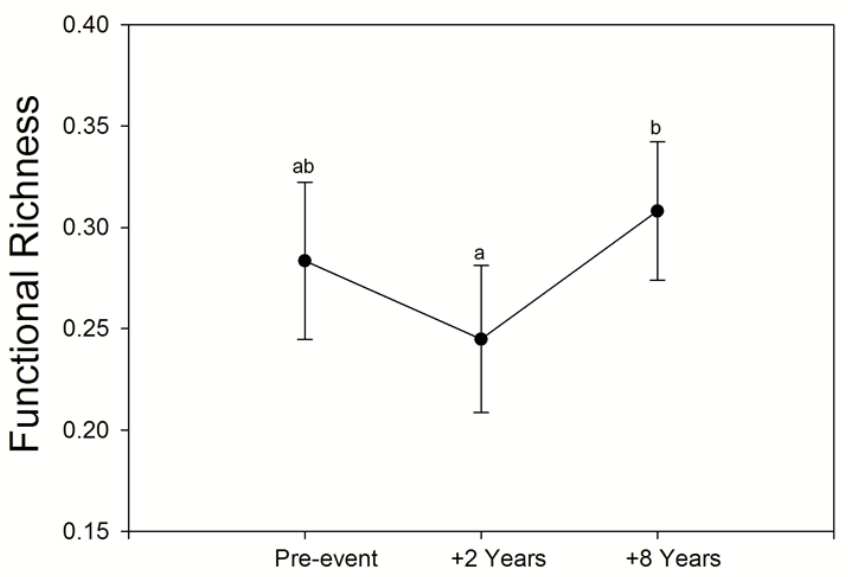

Figure 1. Differences in the functional diversity index (functional richness) with time (pre-event, +2 years, +8 years). Different letters denote significant differences between groups (repeatedmeasures ANOVA, Least Significant Difference post -hoc test).

Stepwise discriminant analysis indicated that the adult and recruit groups differed in functional richness $\left(\mathrm{F}_{\text {Rich }}\right)$ and seed mass $\left(\mathrm{S}_{\text {massCWM }}\right)$, since these variables explained most variation in the analysis (Fig. 5). Only the first function of the discriminant analysis that corresponded to opposite values of $\mathrm{F}_{\text {Rich }}$ and $\mathrm{S}_{\text {massCWM }}$ - was significant $(P<0.001)$ and explained about $94 \%$ of total variance. All pairwise comparisons between groups had significantly different distances $(P<0.005$, except +2 and +8 years adults - which showed no differences). The communities of juveniles ( +8 years) showed higher values of $\mathrm{S}_{\text {massCwM }}$ and lower values of $F_{\text {Rich }}$ than seedlings $(+2$ years). Also, seedlings had higher $\mathrm{S}_{\text {massCwM }}$ and lower $\mathrm{F}_{\text {Rich }}$ values than adults (both +2 and +8 years) (Fig. 5 ).

\section{DISCUSSION}

This study supports the high functional resilience of Mediterranean shrubland communities to different disturbances, that has been widely reported after wildfires (Díaz-Delgado et al. 2002; Lloret and Zedler 2009), and expands its significance for other strong environmental fluctuations such as those derived from extreme climatic events. In addition, our findings reveal that these resilience mechanisms do not necessarily imply that the same species composition remains at a local scale. After an episodic disturbance plant competition could decrease, thus facilitating species replacement (Fattorini and Halle 2004), but we did not observe major changes in the functional structure of the communities in the short- or medium-term. 
Effects of the climatic event on the functional diversity

The functional diversity (measured as $F_{\text {Rich }}$ ) of the shrubland communities tended to diminish after the extreme climatic episode, but the initial diversity values had been restored after eight years. This decrease in functional richness can be explained mostly by the response of some individual species (Mason et al. 2005), such as Calluna vulgaris - which was not recorded two years after the event but had increased its abundance eight years after (Supplementary Table S1). This later increase could be attributable to the well-known resprouting ability of this species. However, a change in functional richness does not always imply a change in other functional indexes $\left(\mathrm{F}_{\text {Eve }}\right.$ and $\left.\mathrm{F}_{\text {Div }}\right)$, particularly when the abundance within the niche space remains invariable (Mason et al. 2005). The variation of functional richness indicates that the stressful environmental conditions of high water deficit and low temperature acted as a temporal filtering pulse on the vegetation. A higher functional diversity may imply a higher number of species groups living at the edge of their physiological tolerance thresholds. This, in turn, may mean that plants from a higher number of species will be stressed, damaged or dead (Parmesan et al. 2000) due to a variety of hazards and extreme climatic episodes, potentially promoting notable compositional changes (Stampfli and Zeiter 2004). Thus, as we hypothesised, the climatic episode that happened in 2005 induced high canopy losses in the Doñana shrubland, operating as an environmental filter that produced a remarkable loss of functional diversity, initially increasing the functional homogeneity. The loss of plant cover of the dominant species allowed the establishment of others via sexual regeneration (del Cacho and Lloret 2012) or favoured their self-replacement due to the resprouting potential of some of these shrubs (Lloret and Zedler 2009). Such a high rate of community recovery might explain the subsequent increase detected in functional richness eight years after the event, and hence the high recovery rate of the functional heterogeneity.

With regard to the functional divergence, which indicates the abundance of species with specialised functional trait values (Villeger et al. 2010), the communities with higher values of $F_{\text {Div }}$ exhibited a lower resilience composition (Rs-comp) value with time (i.e. lower stability). Thus, a higher functional divergence was associated with a lower stability of species composition over time. However, these communities maintained higher values of functional divergence eight years after the event. They did not suffer a significant loss of functional diversity in spite of experiencing higher rates of species replacement. This combination of high functional diversity and species turnover can be possible when changes in abundance occur in species that are functionally redundant, likely because their functional traits are related to the major drivers of ecosystem processes - in our case response to water deficit - (effect traits) or because it allows the maintenance of populations - in our case mostly by seedling establishment - (response traits) (Villéger 2010). In general, a
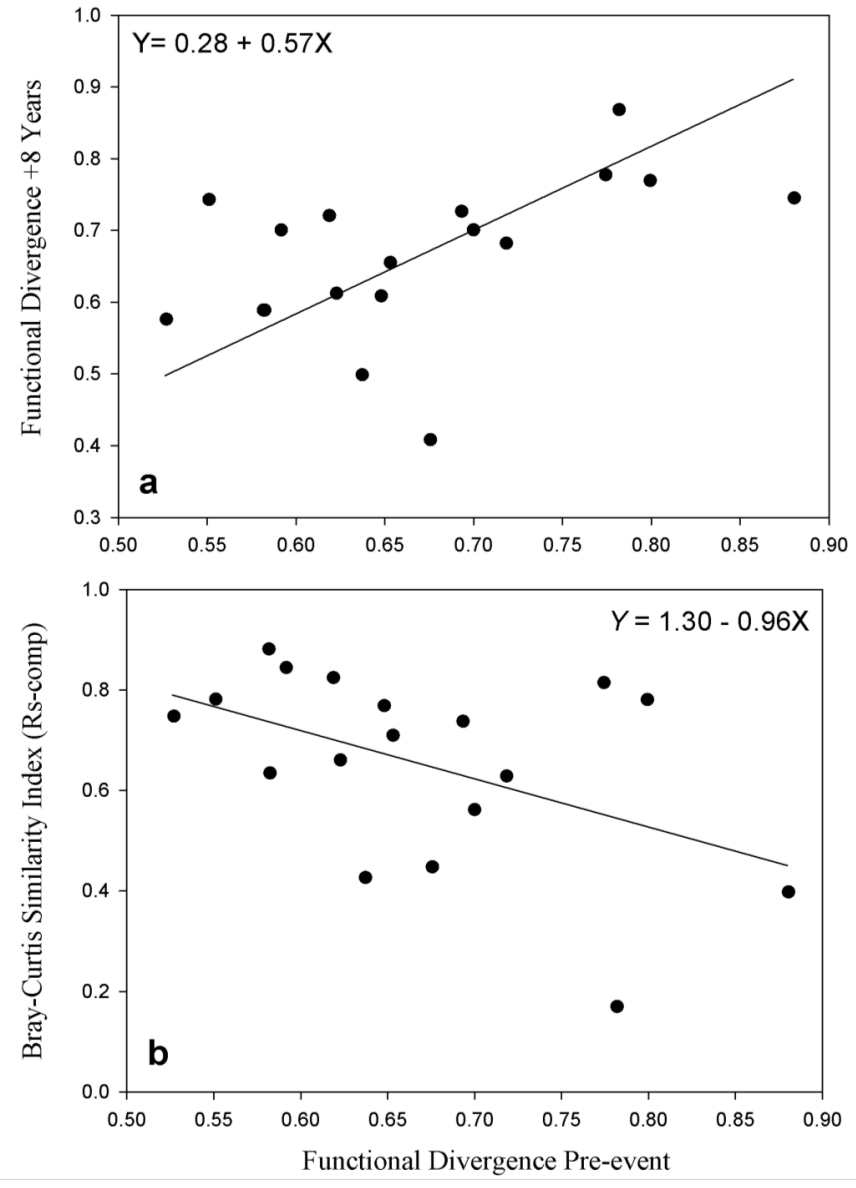

Figure 2. Relationship between the functional divergence (pre-event) and (a) the functional divergence after 8 years and (b) the Bray-Curtis similarity index. The significance level was $P<0.05$ for the two cases.

disturbance in the ecosystem can promote the replacement of dominant species by other, less abundant competitors with similar functional properties (Naeem 1998; Walker et al. 1999), which does not induce strong changes in ecosystem functioning (Schindler 1990; Cingolani et al. 2005). In our case study, two of the most dominant species prior to the climatic event, Halimium halimifolium and Rosmarinus officinalis (Supplementary Table S1), were partially replaced by other, functionally closer species - such as Cistus libanotis and Lavandula stoechas - after the climatic episode, as shown by their relative proximity in the PCA analysis (Supplementary Fig. S4). Besides, communities with higher $F_{\text {Div }}$ maintained their levels over time, suggesting that the most diverse communities have more variable niche widths and, thereby, higher functional stability (Tilman 2004).

Functional traits and stability after the extreme climatic event

The most stable shrubland communities (with more resistance) were those dominated by species having traits more closely associated with drought resistance, such as higher values of root and stem dry matter $\left(\mathrm{RDMC}_{\mathrm{CWM}}\right.$ and $\left.\mathrm{SDMC}_{\mathrm{CWM}}\right)$ and lower values of spe- 
cific root area $\left(\mathrm{SRA}_{\mathrm{CWM}}\right)$ (Poorter and Markesteijn 2008). A large thawing rate in drought-prone ecosystems increases the probability of xylem embolism, as a result of high daily temperature oscillations (Granda et al. 2014). Thus, higher values of SDMC might confer an advantage because they reduce the plant vulnerability to xylem cavitation promoted by unusually low temperatures (Hacke et al. 2001). Similarly, Polley et al. (2013) and Majekova et al. (2014) found, in grasslands communities, that leaf dry matter content was the best predictor associated with greater population temporal stability, the more conservative and slow-growing species being more stable over time.

In addition, the communities with higher rates of recovery of plant growth after the disturbance (higher resilience) were positively related to higher values of chlorophyll in their dominant species. A higher concentration of leaf chlorophyll is closely correlated with a higher mass-based maximum photosynthetic rate (Evans and Poorter 2001), and thus with faster plant growth (Poorter and Remkes 1990). Previous studies have also shown that ecosystems with a higher flux of energy are usually more resilient to disturbances, likely because they have the potential to exhibit rapid rates of vegetation recovery (Begon et al. 2006).

Our results are in accordance with previous studies suggesting that plants have developed mechanisms of stability to cope with adverse climatic stressors. Thus, whereas the ability to tolerate the climatic event is restricted to certain functional traits related with a resource-conservation strategy, we found that one trait of the plants which correlated with their resilience after disturbance was related to their acquisition strategies. However, in spite of the contrasting patterns obtained in this study, we found that the existence of relationships between community functional traits and resistance or resilience responses was limited to a relatively low number of functional attributes. There are several ways to interpret this limited ability of the community functional traits to act as predictors of community resistance/resilience to disturbances. On the one hand, the shrub species of 'monte blanco' share similar functional characteristics that should be well adapted to the dry environment and the great seasonal thermal amplitude of the Mediterranean environment that they inhabit (Diaz-Barradas et al. 1999; Zunzunegui et al. 2005; Granda et al. 2014). In this sense, when considering groups of species belonging to environmentally similar sites, the general trends (e.g. the axis of acquisition-conservation strategies; Wright et al. 2004) became weaker or disappear (de la Riva et al. 2016). At a larger spatial scale, all the species studied tend to exhibit a more conservative strategy and are closely grouped in the same functional space within the regional species pool (de la Riva et al. 2016; Supplementary Fig. S5). On the other hand, the combination of different climatic stressors (low temperatures and water deficit) during the event, which could result in contrasting or even opposite relationships with certain functional traits (Dreesen et al. 2012; Granda et al. 2014), may be responsible for the limited relationships found between functional traits and stability indexes (resistance or re- silience).
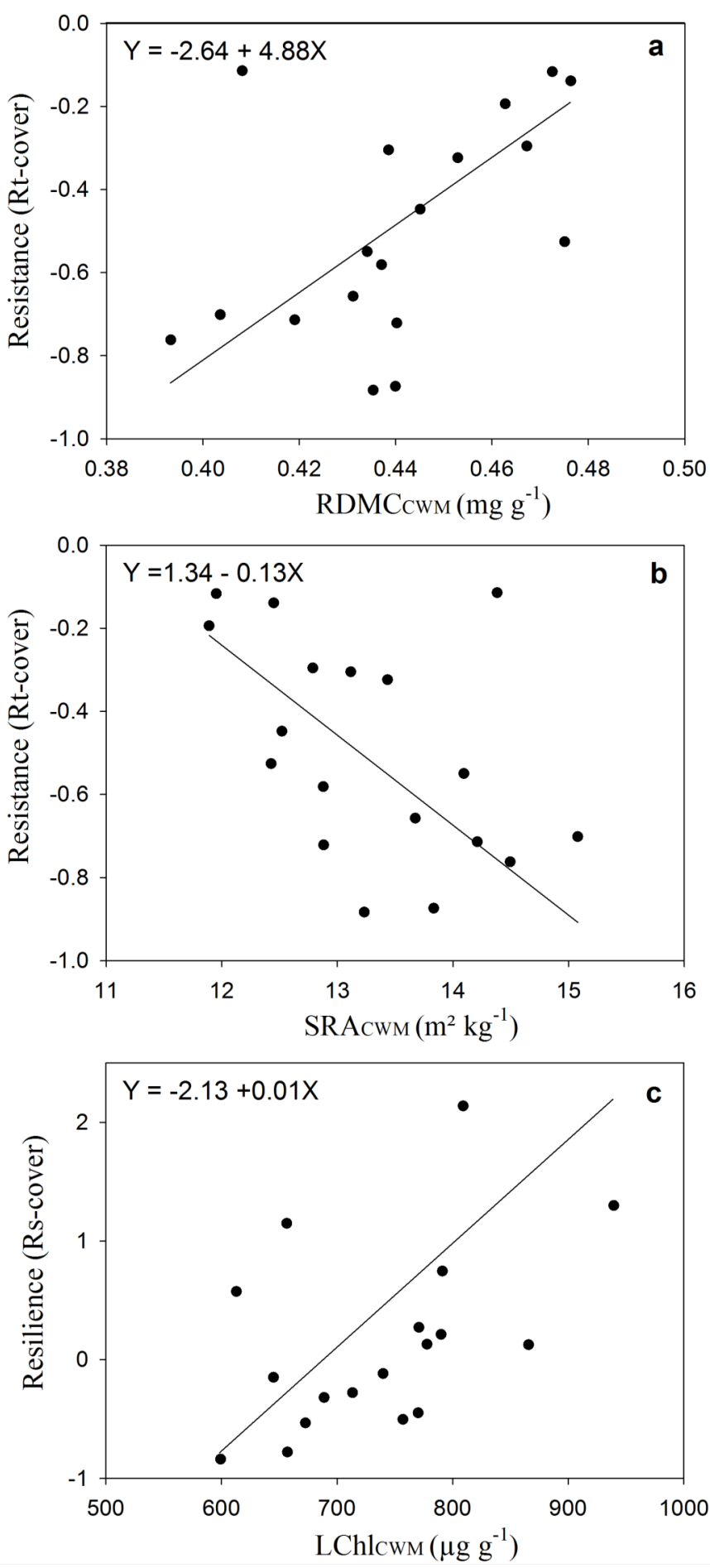

Figure 3. Relationship between the community resistance and community functional traits: (a) root dry matter content $\left(\mathrm{RDMC}_{\mathrm{CWM}}\right)$ and (b) specific root area $\left(\mathrm{SRA}_{\mathrm{CWM}}\right)$; and between the community resilience and (c) community chlorophyll content $\left(\mathrm{LChl}_{\mathrm{CWM}}\right)$. The significance level was $P<0.05$ for all cases. See Table 1 for abbreviations.

After the extreme climatic episode analysed in this study, the main change in the functional characteristics of the community was an increase in the relative 

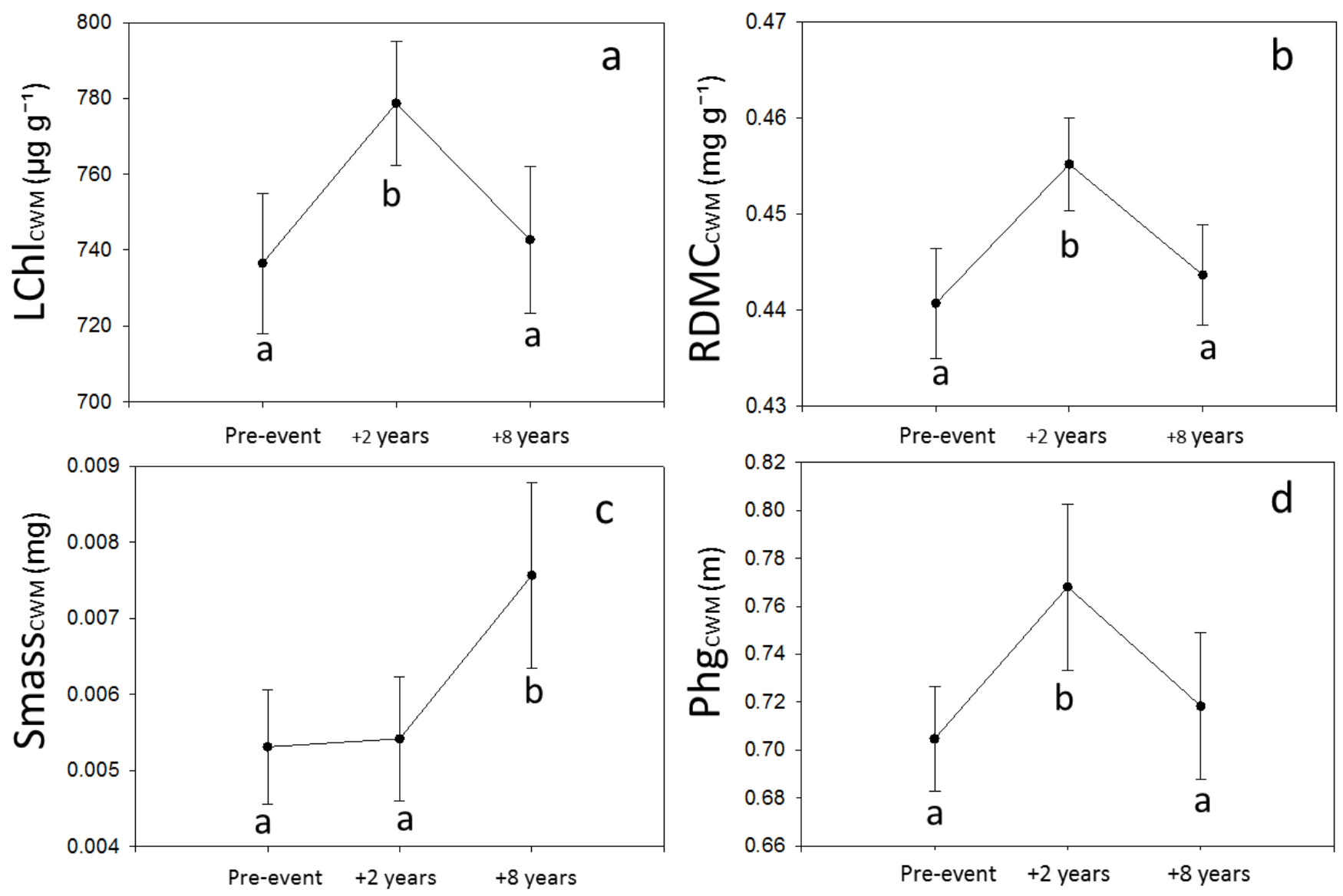

Figure 4. Differences between community-weighted (CWMs) traits with time (pre-event, +2 years, +8 years). See abbreviations in Table 1. Different letters denote significant differences between groups (repeated-measures ANOVA and Least Significant Difference post-hoc test).

abundance of dominant species with greater root dry matter content, leaf chlorophyll or plant height. Thus, the climatic event promoted rapid changes in the structure and composition of the shrubland communities studied, with a massive dieback of canopies (del Cacho and Lloret 2012). This pattern is consistent with previous reports on changes at the regional scale in woodlands from SW North America (Breshears et al. 2005). However, the functional attributes of the communities of Doñana exhibited, overall, a remarkable resilience, as they tended to return quickly to their initial (preevent) states.

Recruitment, community structure and functional diversity

The combination of demographic and functional attributes in our study enabled us to detect remarkable differences in the functional diversity of different demographic stages in the shrubland communities studied: it was higher for the adult than for the recruit stage. There was a lower number of species for the seedling and juvenile stages than for the adults, likely because not all the shrub species were successful recruiters. This uncoupling between the composition of the canopy and the community of seedlings and saplings has been observed in other Mediterranean forests (Pérez-Ramos and Marañón 2012), which supports the possibility of future shifts in species composition. We propose that the extreme drought event could also have resulted in lower functional diversity $\left(\mathrm{F}_{\text {Rich }}\right)$ in the recruits since it could have affected more severely the early life-history stages of some species (Vallejo et al. 1999; Pratt et al. 2007; González-Rodríguez et al. 2011). In addition, when exploring the more relevant traits of the recruits, we found higher community values of seed mass at the seedling and juvenile stages than at the adult stage. Seedlings which originate from larger seeds could have a competitive advantage to cope with drought, because they are able to develop deeper roots and forage for water in deep soil layers over the dry season (Westoby et al. 2002; Quero et al. 2007).

In conclusion, extreme climatic events can initiate stochastic succession, with more important effects over the first years (Kreyling et al. 2011). In this study we show how these climatic events also have consequences for the functional properties of the community, with potential influences on ecosystem functioning (Grime 2001). However, the high recovery ability detected in these shrubland communities supports the existence of important mechanisms of resilience to extreme climatic episodes (Lloret et al. 2012). Our findings reveal that, in spite of the stability of the functional structure, replacement by species with similar traits exists. In addition, there was no colonisation by new 


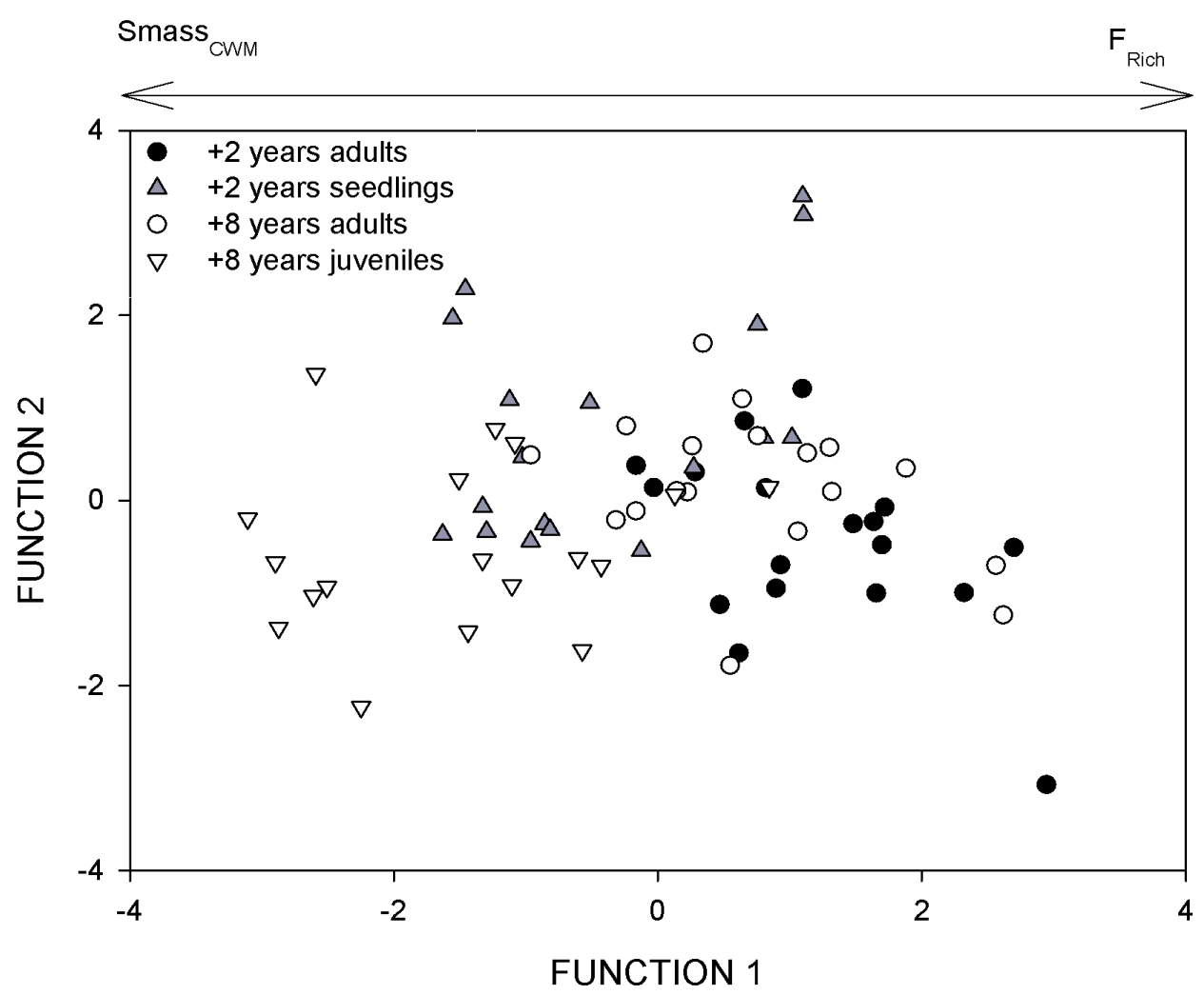

Figure 5. Mean scores of the different vegetation communities on the two canonical discriminant functions obtained by stepwise discriminant analysis. Only the first function was significant $(P<0.001)$ and was determined by $\mathrm{F}_{\text {Rich }}$ and $\mathrm{S}_{\text {massCwm. }}$. Discriminant analysis was performed for the different surveys, with the functional community traits (CWM) and functional diversity indexes as independent variables and the groups of adults and recruits two and eight years after the event $(+2$ years and +8 years adults, +2 years seedlings, +8 years juveniles) to be discriminated. See Table 1 for abbreviations.

species in the community and the recruits did not provide substantial differences to the community functional structure, seed mass being the only trait whose community values (weighted means) differed significantly between the adult and recruit stages.

\section{ACKNOWLEDGEMENTS}

We are grateful for the support of the staff in the Doñana Biological Reserve, and for the help of C. Padilla, C. Navarro and M. Olmo during field sampling and trait measurements. This study was funded by the Spanish MEC projects DIVERBOS (CGL2011-30285-C02-01 and C02-02), SECADIN (CGL2012-32965) and ECO-MEDIT (CGL2014-53236-R), the Catalonian 2014-SGR-453 grant, the ICTS-Reserva Biológica de Doñana projects 38/2007, 27/2009 and 11/2013, and European FEDER funds. Isotopic analysis was carried out in the LIE of EBD (CSIC), multielemental analysis of soil and plant samples in the IRNAS Analysis Service and leaf $\mathrm{N}$ analysis in the SCAI of the University of Córdoba. We also acknowledge the Doñana Monitoring Team of Estación Biológica de Doñana for providing the long-term ecological monitoring data.

\section{REFERENCES}

Bastolla U, Fortuna M A, Pascual-García A, et al. (2009) The architecture of mutualistic networks minimizes com- petition and increases biodiversity. Nature 458: 1018 1020 .

Begon M, Townsend CR, and Harper JL(2006) Ecology: from individuals to ecosystems. Blackwell Publishing Ltd.

Bray JR.,and Curtis JT (1957) An ordination of the upland forest communities of southern Wisconsin. Ecol Monogr 27: 325-349.

Breshears DD, Cobb NS, Rich PM et al. (2005) Regional vegetation die-off in response to global-change-type drought. Proc Natl Acad Sci USA 102:15144-15148.

Carlucci MB, Streit H, Duarte LD S, and Pillar VD (2012) Individual-based trait analyses reveal assembly patterns in tree sapling communities. J Veg Sci 23: 176186.

Cingolani AM, Posse G, and Collantes MB (2005) Plant functional traits, herbivore selectivity and response to sheep grazing in Patagonian steppe grasslands. J Appl Ecol 42: 50-59.

de Bello F, Lavorel S, Diaz S, et al. (2010) Towards an assessment of multiple ecosystem processes and services via functional traits. Biodivers Conserv 19: 2873 -2893 .

del Cacho M, and Lloret F (2012) Resilience of Mediterranean shrubland to a severe drought episode: the role of seed bank and seedling emergence. Plant Biology 14: 458-66.

de la Riva EG, Pérez-Ramos IM, Tosto A, et al. (2015) Disentangling the relative importance of species occu- 
rrence, abundance and intraspecific variability in community assembly: a trait-based approach at the wholeplant level in Mediterranean forests. Oikos doi:10.5061/dryad.dr275.

de la Riva EG, Tosto A, Perez-Ramos IM, et al.(2016) A plant economics spectrum in Mediterranean forests along environmental gradients: is there coordination among leaf, stem and root traits? J Veg Sci 27: 187199.

Dias TC, Berg MP, Bello FD, and Oosten AR Van (2013) An experimental framework to identify community functional components driving ecosystem processes and services delivery. J Ecol 101:29-37.

Díaz S, and Cabido M (2001) Vive la difference: plant functional diversity matters to ecosystem processes. Trends Ecol Evol 16: 646-655.

Díaz-Barradas D, Zunzunegui M, Tirado R, et al. (1999) Plant functional types and ecosystem function in Mediterranean shrubland. J Veg Sci, 10: 709-716.

Díaz-Delgado, R (2006) Evento de mortalidad en la vegetación terrestre del Parque Nacional de Doñana. Estación Biológica de Doñana, internal report, CSIC, Sevilla, ES.

Díaz-Delgado R, Afán I, and Silva R (2014) Patrones espaciales de daño en copa en el sabinar de la Reserva Biológica de Doñana a consecuencia de un evento extremo de sequía. (eds. Cámara, R., Rodríguez, B. and Muriel, J.L.) Biogeografía de Sistemas Litorales. Dinámica y Conservación, pp. 189-192. Universidad de Sevilla, Sevilla.

Díaz-Delgado R, Lloret F, Pons X, Terradas J(2002) Satellite evidence of decreasing resilience in Mediterranean plant communities after recurrent wildfires. Ecology 83: 2293-2303.

Dreesen FE, De Boeck HJ, Janssens IA, and Nijs I (2012) Summer heat and drought extremes trigger unexpected changes in productivity of a temperate annual/ biannual plant community. Environ Exp Bot 79: 2130 .

Eamus D, and Prior L 2001. Ecophysiology of trees of seasonally dry tropics: Comparisons among phenologies. Adv. Ecol. Res. 32: 113-197.

Easterling DR, Evans JL, Groisman PY, et al. (2000) Observed Variability and Trends in Extreme Climate Events: A Brief Review. Bull Amer Meteorol Soc 81: 417-425.

Evans JR, and Poorter H (2001) Photosynthetic acclimation of plants to growth irradiance: the relative importance of specific leaf area and nitrogen partitioning in maximizing carbon gain. and Plant Cell Environ 24: 755767.

Faith DP, Minchin PR, and Belbin L (1987) Compositional dissimilarity as a robust measure of ecological distance. Vegetatio 69: 57-68.

Farquhar GD, Learyb MHO, and Berry JA (1982) On the relationship between Carbon isotope discrimination and the intercellular Carbon Dioxide concentration in leaves. Aust J Plant Physiol 9: 121-137.

Fattorini M, and Halle S. 2004. The dynamic environmental filter model: how do filtering effects change in assembling communities after disturbance? Assembly Rules in Restoration Ecology - Bridging the Gap between Theory and Practice (eds Temperton, V.M., Hobbs, R., Fattorini, M. and Halle, S.) pp. 96-114. Island Press Books, Washington D.C.

García C, Moracho E, Díaz-Delgado R, and Jordano P (2014) Long-term expansion of juniper populations in managed landscapes: patterns in space and time. $\mathrm{J}$ Ecol 102: 1562-1571.
García-Murillo P, and Sousa-Martín A. 1999. El paisaje vegetal de la zona oeste del Parque Natural de Doñnana (Huelva). Lagasscalia 21: 11-132.

Garnier E, Cortez J, Billes G, Navas ML, et al. (2004) Plant functional markers capture ecosystem properties. Eco$\operatorname{logy} 85$ : 2630-2637.

Gillespie IG, and Loik ME (2004) Pulse events in Great Basin Desert shrublands: physiological responses of Artemisia tridentata and Purshia tridentata seedlings to increased summer precipitation. J Arid Environ 59: 41 -57 .

González-Rodríguez V, Villar R, Casado R,et al. (2011) Spatio-temporal heterogeneity effects on seedling growth and establishment in four Quercus species. Ann For Sci 68: 1217-1232.

Granda E, Scoffoni C, Rubio-Casal A, et al. (2014) Leaf and stem physiological responses to summer and winter extremes of woody species across temperate ecosystems. Oikos 123: 1281-1290.

Grime JP (1998) Benefits of plant diversity to ecosystems: immediate, filter and founder effects. J Ecol 86: 902 910.

Grime JP (2001) Plant Strategies, Vegetation Processes, and Ecosystem Properties, 2nd edn. John Wiley and Sons, Chichester.

Grime JP, Brown VK, Thompson K, et al. (2000) The response of two contrasting limestone grasslands to simulated climate change. Science 289: 762-765.

Hacke UG, Sperry JS, Pockman WTet al. (2001) Trends in wood density and structure are linked to prevention of xylem implosion by negative pressure. Oecologia 126: 457-461.

Hernández EI, Vilagrosa A, Pausas et al. (2010) Morphological traits and water use strategies in seedlings of Mediterranean coexisting species. Plant Ecol 207: 233244.

Hooper DU, Chapin FS, Ewel JJ, and Al E (2005) Effects of biodiversity on ecosystem functioning: a consensus of current knowledge. Ecol Monogr 75: 3-35.

Jackson RB, Mooney HA, and Schulze ED (1997) A global budget for fine root biomass, surface area, and nutrient contents. Proc Natl Acad Sci USA 94: 73627366.

Jentsch A, Kreyling J, Elmer M, et al. (2011) Climate extremes initiate ecosystem-regulating functions while maintaining productivity. J Ecol 99: 689-702.

Kao SC, and Ganguly AR (2011) Intensity, duration, and frequency of precipitation extremes under $21^{\text {st }}$ century warming scenarios. J Geophys Res 116(D16): 19842012.

Kreyling J, Jentsch A,and Beierkuhnlein C (2011) Stochastic trajectories of succession initiated by extreme climatic events. Ecol Lett, 14: 758-64.

Kreyling J, Wenigmann M, Beierkuhnlein C, Jentsch A (2008) Effects of extreme weather events on plant productivity and tissue die-back are modified by community composition. Ecosystems 11: 752-763.

Laliberté E, Shipley B,and Laliberté ME. 2010. Package 'FD'. Measuring functional diversity (FD) from multiple traits, and other tools for funtional ecology.

Lavorel S, Grigulis K, McIntyre S, et al. (2008) Assessing functional diversity in the field - methodology matters! Funct Ecol 22: 134-147.

Lê S, Josse J, Husson F (2008) FactoMineR: an R package for multivariate analysis. Journal of Statistical Software. 25: 1-18.

Lloret, F (2012) Vulnerabilidad y resiliencia de ecosistemas forestales frente a episodios extremos de sequía. Ecosistemas 21: 85-90. 
Lloret F, Keeling E, and Sala A (2011) Tree resilience after successive low-growth episodes in ponderosa pine old forests. Oikos 120: 1909-1920.

Lloret F, Escudero A, Iriondo et al. (2012) Extreme climatic events and vegetation: the role of stabilizing processes. Global Change Biol 18: 797-805.

Lloret F, and Granzow-de la Cerda I (2013) Plant competition and facilitation after extreme drought episodes in Mediterranean shrubland: does damage to vegetation cover trigger replacement by juniper woodland? J Veg Sci 24: 1020-1032.

Lloret F, and López-Soria L (1993) Resprouting of Erica multiflora after experimental fire treatments. J Veg Sci 4: $367-374$

Lloret F, Mattana S, and Curiel-Yuste J (2015) Climateinduced die-off affects plant- soil microbe ecological relationship and functioning. FEMS Microbiol Ecol 91: 1-12.

Lloret F, Peñuelas J, and Estiarte M (2005) Effects of vegetation canopy and climate on seedling establishment in Mediterranean shrubland. J Veg Sci 16: 67-76.

Lloret F, and Zedler PH (2009) The effect of forest fire on vegetation. (eds. Cerda, A. and Robichaud, P.R.) Fire effects on soils and restoration strategies, pp. 257295.

Lloret F, de la Riva EG, Pérez-Ramos IM, et al. (2016) Climatic events inducing die-off in Mediterranean shrublands: Are species responses. Oecologia doi: 10.1007/s00442-016-3550-4.

Majekova, M, De Bello, F, Dolezal, J, and Leps, J (2014) Plant functional traits as determinants of population stability. Ecology 95: 2369-2374.

Martínez F, Merino O, Martín A, et al. (1998) Belowground structure and production in a Mediterranean sand dune shrub community. Plant Soil 201: 209-216.

Mason NWH, Mouillot D, Lee WG, et al. (2005) Functional richness, functional evenness and functional divergence: the primary components of functional diversity. Oikos 111: 112-118.

Mason NWH, Richardson SJ, Peltzer DA, de Bello F, Wardle DA, and Allen RB. (2012). Changes in coexistence mechanisms along a long-term soil chronosequence revealed by functional trait diversity. J Ecol 100: 678689.

Mouchet MA, Villeger S, Mason et al. (2010) Functional diversity measures: an overview of their redundancy and their ability to discriminate community assembly rules. Funct Ecol 24: 867-876.

Muñoz-Reinoso JC, and García-Novo F (2005) Ontogenetic shifts in interactions of two dominant shrub species in a semi-arid coastal sand dune system. Landscape Ecol 20: $51-61$.

Naeem S (1998) Species Redundancy and Ecosystem Reliability. Conserv Biol 12: 39-45.

Padilla FM, Pugnaire FI (2007) Rooting depth and soil moisture control Mediterranean woody seedling survival during drought. Funct Ecol 21: 489-495.

Parmesan C, Root TL, and Willig MR(2000) Impacts of Extreme Weather and Climate on Terrestrial biota. Bull Amer Meteorol Soc 81: 443-450.

Pérez-Harguindeguy N, Díaz S, Garnier E,et al. (2013) New handbook for standardised measurement of plant functional traits worldwide. Aust J Bot 61: 167-234.

Pérez-Ramos, IM, Gómez-Aparicio L, Villar R, Garcia LV and Marañón T 2010. Seedling growth and morphology of three oak species along field resource gradients and seed mass variation: a seedling agedependent response. J Veg Sci 21: 419-437

Pérez-Ramos, IM, andMarañón T (2012) Community-level seedling dynamics in Mediterranean forests: uncoupling between the canopy and the seedling layers. J Veg Sci 23: 526-540.

Pérez-Ramos IM, Roumet C, Cruz P, et al. (2012) Evidence for a "plant community economics spectrum" driven by nutrient and water limitations in a Mediterranean rangeland of southern France. J Ecol. 100: 13151327.

Pérez-Ramos IM, Volaire F, Fattet M, et al. (2013). Tradeoffs between functional strategies for resource-use and drought-survival in Mediterranean rangeland species. Environ Exp Bot 87: 126-136.

Pinheiro J, Bates D, DebRoy S, Sarkar D and R Core Team (2015). nlme: Linear and Nonlinear Mixed Effects Models. R package version 3.1-121, http://CRAN.Rproject.org/package $=$ nlme

Polley, HW, Isbell FI, and Wilsey BJ(2013) Plant functional traits improve diversity-based predictions of temporal stability of grassland productivity. Oikos 122: 12751282.

Poorter L, and Markesteijn L (2008) Seedling traits determine drought tolerance of tropical tree species. Biotropica 40: 321-331.

Poorter H, Remkes C (1990) Leaf area ratio and net assimilation rate of 24 wild species differing in relative growth rate. Oecologia 83: 553-559.

Potts DL, Huxman TE, Enquist BJ, et al. (2006). Resilience and resistance of ecosystem functional response to a precipitation pulse in a semi-arid grassland. J Ecol 94: 23-30.

Pratt RB, Jacobsen AL, Golgotiu KA, (2007) Life history type and water stress tolerance in nine California chaparral species (Rhamnaceae). Ecol Monogr 77: 239253.

Quero JL, Villar R, Marañon T, et al. (2007) Seed mass effects in four mediterranean Quercus species (Fagaceae) growing in contrasting light environments. Am J of Bot 94: 1795-1803.

Sangüesa-Barreda G, Linares JC, and Camarero JJ (2012) Mistletoe effects on Scots pine decline following drought events: insights from within-tree spatial patterns, growth and carbohydrates. Tree Physiol 32: 585 -98 .

Saura-Mas S, Shipley B, Lloret F (2009) Relationship between post-fire regenerationion and leaf economics spectrum in Mediterranean woody species. Funct Ecol 23: $103-110$.

Schindler DW (1990) Experimental perturbations of whole lakes as tests of hypotheses concerning ecosystem structure and function. Oikos 57: 25-41

Sokal RR, Rohlf FJ (1995) Biometry: the principals and practice of statistics in biological research. WH Freeman and Company, New York.

Stampfli A, Zeiter M (2004) Plant regeneration directs changes in grassland composition after extreme drought: a 13-year study in southern Switzerland. J Ecol 92: 568 -576 .

Sternberg M, Brown VK, Masters GJ and Clarke IP (1999) Plant community dynamics in a calcareous grassland under climate change manipulations. Plant Ecol 143 29-37.

Trabucco A, and Zomer RJ (2009) Global Aridity Index (Global-Aridity) and Global Potential EvapoTranspiration (Global-PET) Geospatial Database. CGIAR Consortium for Spatial Information. Published online, available from the CGIAR-CSI GeoPortal at: http://www.csi.cgiar.org.

Tilman D (2004) Niche tradeoffs, neutrality, and community structure: a stochastic theory of resource competition, 
invasion, and community assembly. Proc Natl Acad Sci USA 101: 10854-61.

Tilman D, Reich PB. and Knops JMH (2006) Biodiversity and ecosystem stability in a decade-long grassland experiment. Nature 441: 629-632.

van Ruijven J, and Berendse, F (2010) Diversity enhances community recovery, but not resistance, after drought. J Ecol 98: 81-86.

Vallejo VR, Bautista S, and Cortina J (1999) Restoration for soil protection after disturbances. pp 301-344 (ed. Trabaud, L.) Life and Environment in the Mediterranean, WIT Press: Southampton.

Villéger S, Mason NWH, and Mouillot D (2008) New multidimensional functional diversity indices for a multifaceted framework in functional ecology. Ecology 89: 2290-301.

Villéger S, Ramos Miranda J, Flores Hernández D, and Mouillot D (2010) Contrasting changes in taxonomic vs. functional diversity of tropical fish communities after habitat degradation. Ecol Appl 20: 1512-22.

Walker B, Kinzig A, and Langridge J (1999) Original articles: plant attribute diversity, resilience, and ecosystem function: the nature and significance of dominant and minor species. Ecosystems 2: 95-113.

Weiher E (2010) A primer of trait and functional diversity. In Biological diversity: frontiers in measurement and assessment (eds Magurran A. E., McGill B. J.), pp. 175-193. Oxford, UK: Oxford University Press.

Westoby M, Falster DS, Moles AT, et al. (2002) Plant ecological strategies: some leading dimensions of variation between species. Annu Rev Ecol Evol Syst 33: 125159.

White TA, Campbell BD, Kemp PD, and Hunt CL (2000) Sensitivity of three grassland communities to simulated extreme temperature and rainfall events. Global Change Biol 6: 671-684.

Wintermans JFGM, DeMots A (1965) Spectrophotometric characteristics of chlorophylls $\mathrm{a}$ and $\mathrm{b}$ and their pheophytins in ethanol. Biochim Biophys Acta 109: 448-453.

Wright IJ, Reich PB, Westoby M, et al. (2004) The worldwide leaf economics spectrum. Nature 428: 821 $-827$.

Yachi S, Loreau M (1999) Biodiversity and ecosystem productivity in a fluctuating environment: the insurance hypothesis. Proc Natl Acad Sci USA 96: 1463-1468

Zunzunegui M, Barradas MD, Ain-Lhout Fet al. (2005) To live or to survive in Doñana dunes: adaptive responses of woody species under a Mediterranean climate. Plant Soil 273: 77-89. 


\section{Supplementary material for Online publication only}

Figure S1. Aerial photographs of the shrublands after the climatic event. Fotos by Hector Garrido (Estación Biológica de Doñana).

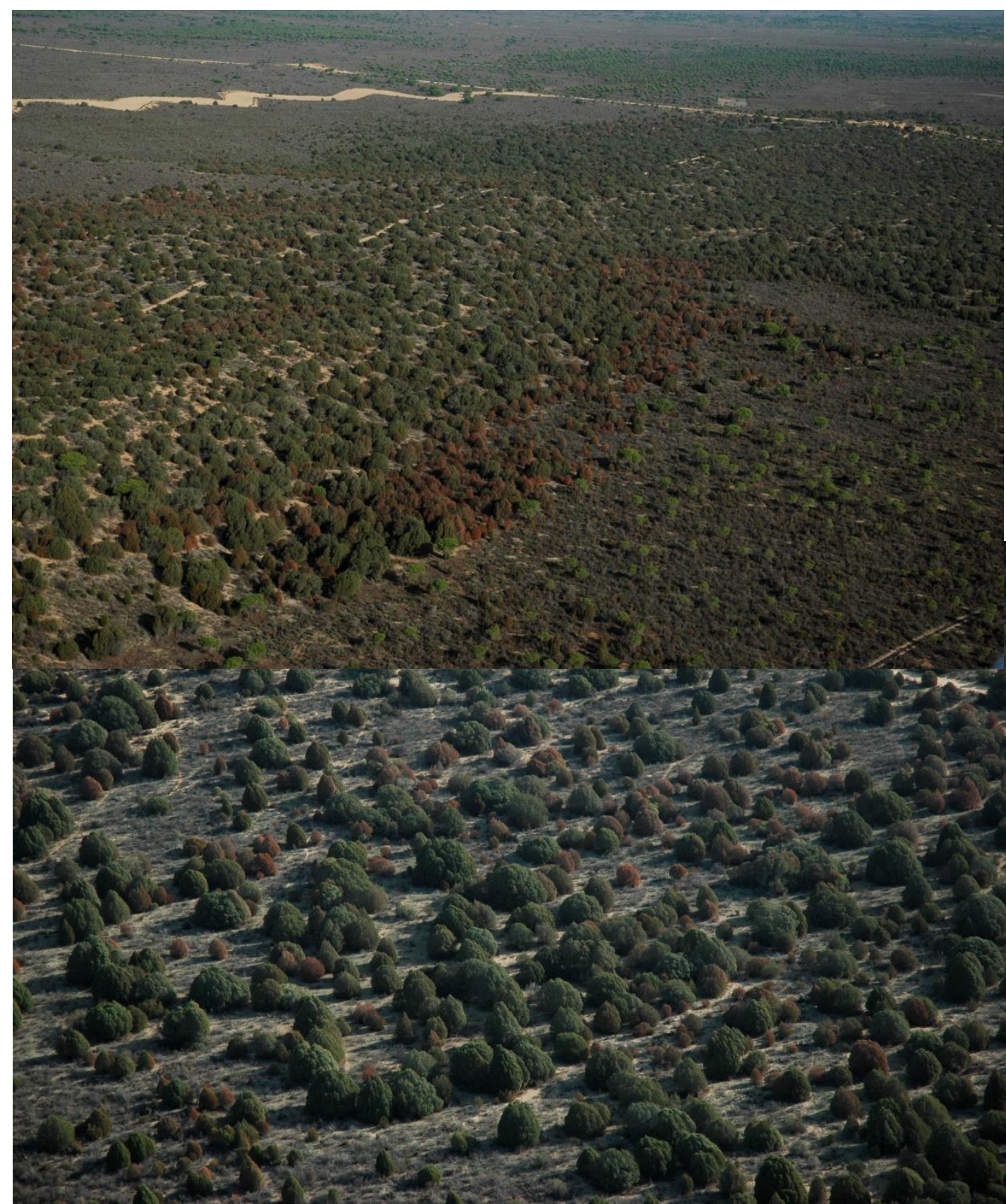


Figure S2. Mean total precipitation (grey bars), mean minimum temperature (average from January and Februry; blue line) and total frost days (days with minimum temperature equal or below $0^{\circ} \mathrm{C}$; red line) in Doñana National Park.

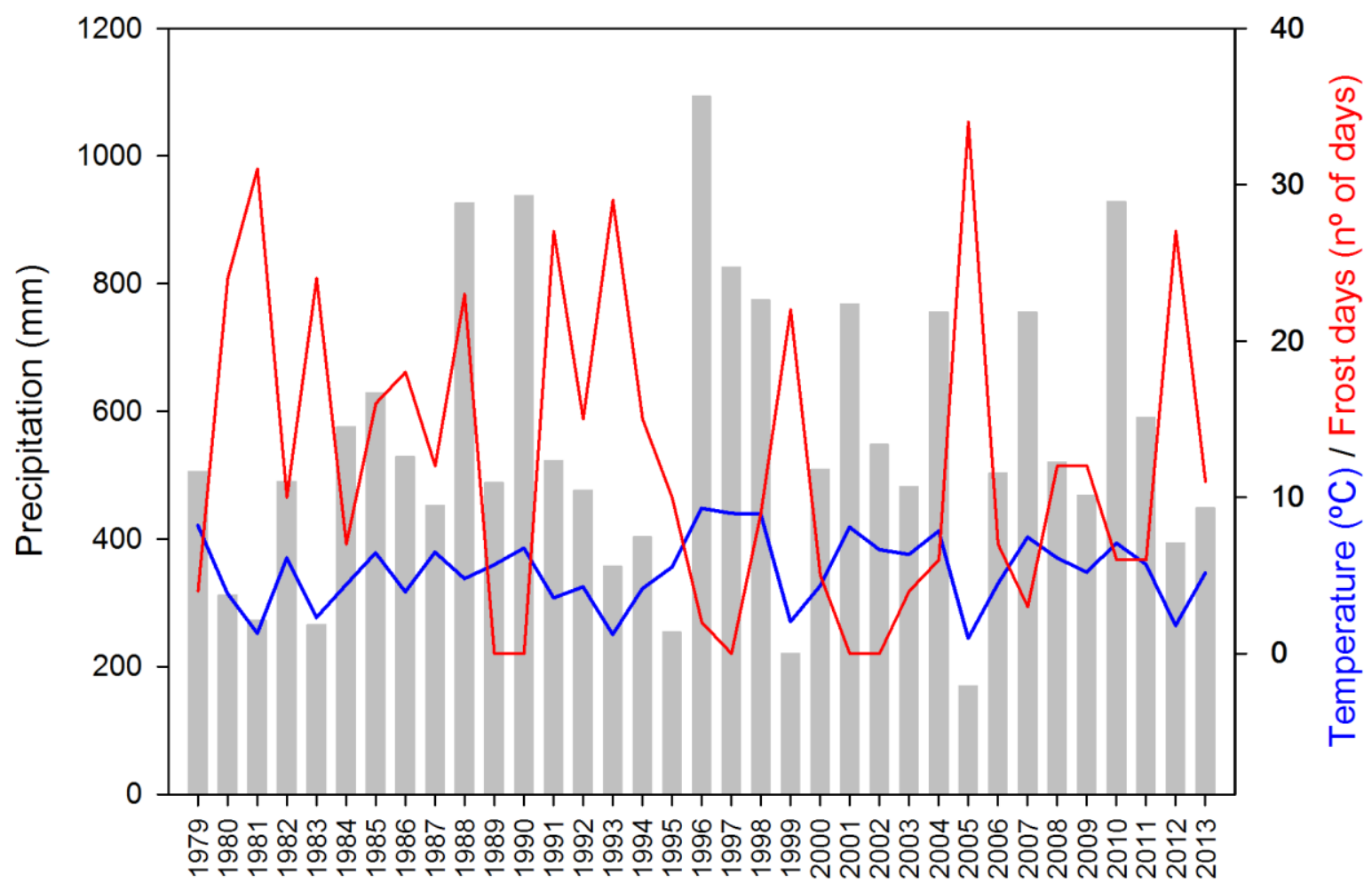


Figure S3. NDVI (mean, SD bars, after linearly scaling to values ranging from 0 to 255) obtained from Landsat imagery for $30 \times 30 \mathrm{~m}^{2}$ pixels $(n=21)$ corresponding to the locations of the sampled plots. The images were obtained in the same month (November) in which the 2007 survey was performed. Note that images for several years were not available due to clouds. Different letters indicate significant differences (LSM Student's t test $P<0.005$ ). The figure illustrate (1) loss of vegetation greenness (correlated to plant cover and LAI) in 2005, the year of the extreme climatic episode; (2) that loss of canopy cover in 2007 remained similarly low than in 2005, supporting that the sampling in that year is a reliable estimation of the impact of the 2005 climatic event on vegetation cover; (3) recovery of canopy cover after 2007.

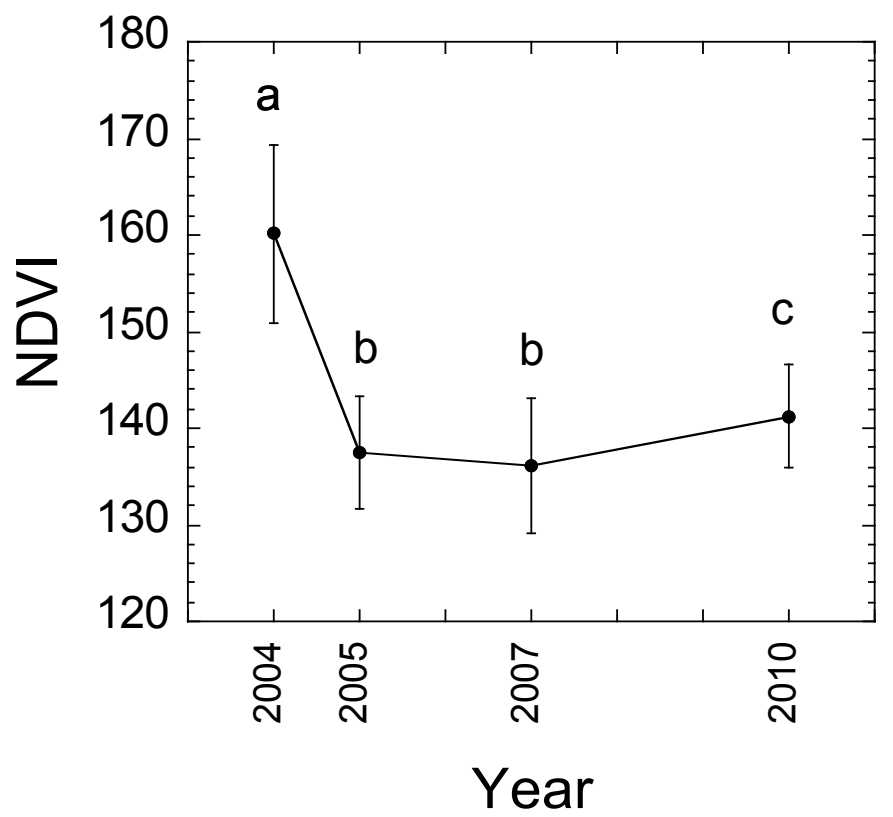


Figure S4. PCA scores for the ten functional traits (abbreviations in Table 1) and the 16 shrub species considered in this study (abbreviations for traits in Table 1 a for species in Appendix S4).

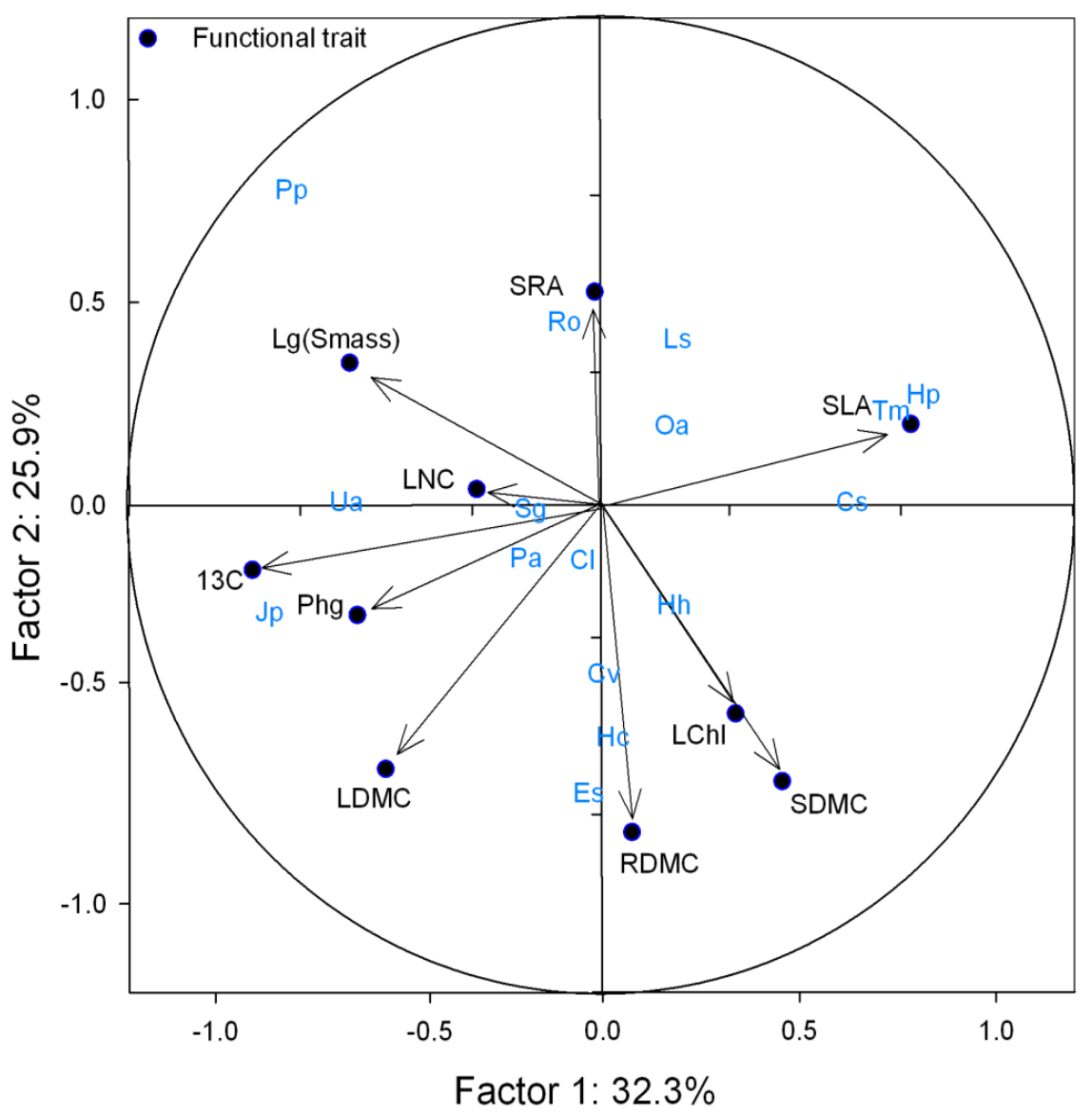


Figure S5. PCA scores for functional traits (abbreviations in Table 1) and a pool of woody Mediterranean species from this Doñana study (red points) and 38 species from a regional environment gradient covering from Mediterranean shrublands to mixed deciduous-evergreen forests (Gradient, blue points; de la Riva et al. 2016). The plant economics spectrum corresponded to Factor 1, being the species from Doñana situated at the conservative site of the spectrum (on the right of the PCA axis). On the table below we showed the means, standard deviations and ranges of the functional traits of the two groups of species (Doñana and Gradient). Abbreviations in Table 1.

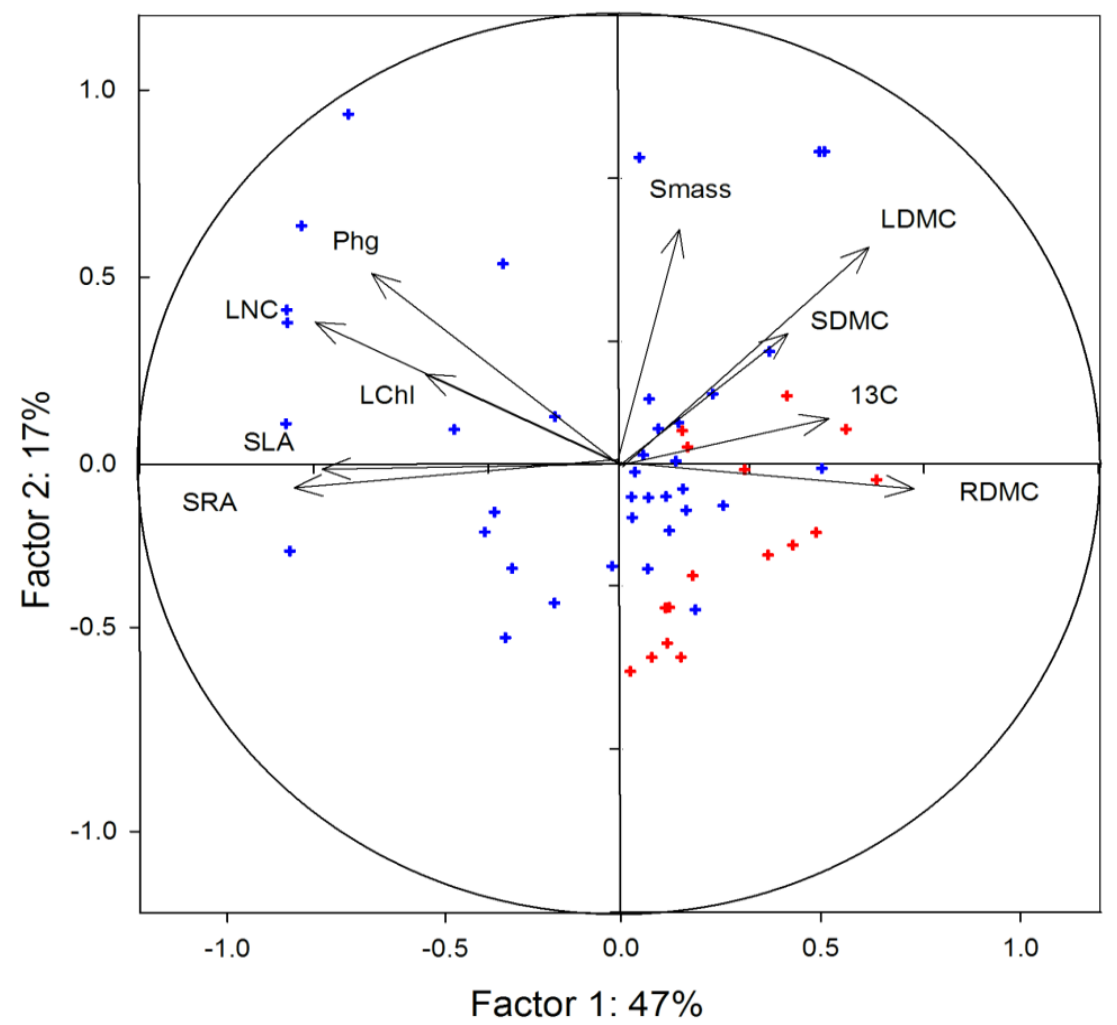

\begin{tabular}{|c|c|c|c|c|c|c|}
\hline & \multicolumn{3}{|c|}{ DOÑANA } & \multicolumn{3}{|c|}{ GRADIENT } \\
\hline & Mean & St.dev & Range & Mean & St.dev & Range \\
\hline LDMC & 0.39 & 0.11 & $0.31-0.50$ & 0.39 & 0.07 & $0.23-0.54$ \\
\hline SLA & 7.41 & 3.22 & $3.71-12.6$ & 12.95 & 7.29 & $4.45-32.3$ \\
\hline SDMC & 0.47 & 0.13 & $0.30-0.54$ & 0.47 & 0.07 & $0.22-0.58$ \\
\hline RDMC & 0.44 & 0.12 & $0.37-0.50$ & 0.35 & 66.40 & $0.20-0.45$ \\
\hline SRA & 13.79 & 4.50 & $8.20-16.6$ & 16.46 & 4.44 & $11.25-28.37$ \\
\hline LChl & 749.65 & 355.66 & $349.3-1268.3$ & 1518.73 & 809.95 & $628.4-3188.3$ \\
\hline$\delta^{13} \mathrm{C}$ & -27.50 & 6.85 & $(-30.31)-(-26.05)$ & -28.31 & 1.27 & $(-31.80)-(-26.75)$ \\
\hline LNC & 2.07 & 0.83 & $1.45-3.86$ & 2.19 & 0.60 & $1.42-3.45$ \\
\hline Smass & 0.05 & 0.14 & $0.0001-0.60$ & 0.26 & 0.75 & $0.0001-2.94$ \\
\hline Phg & 0.93 & 0.53 & 0.38-1.69 & 3.62 & 3.01 & $0.30-11.45$ \\
\hline
\end{tabular}


Table S1. Species studied, abbreviations and plant mean abundances (\%) of all plots: (a) abundance measured considering the total of volume of each species per plot, and (b) abundance measured considering the total number of adults and recruits (seedling +2 years after the event and juveniles +8 years after the event).

\begin{tabular}{llcccc}
\hline a & & \multicolumn{3}{c}{ TOTAL VOLUME } \\
\cline { 5 - 6 } Species & abb & PRE-EVENT & +2 YEARS & +8 YEARS \\
\cline { 6 - 6 } \cline { 5 - 6 } Calluna vulgaris & $\mathrm{Cv}$ & 0.03 & & 0.00 & 0.17 \\
Cistus libanotis & $\mathrm{Cl}$ & 12.49 & & 10.98 & 17.28 \\
Cistus salvifolius & $\mathrm{Cs}$ & 0.00 & & $<.01$ & 0.00 \\
Erica scoparia & $\mathrm{Es}$ & 1.19 & & 2.22 & 2.20 \\
Halimium commutatum & $\mathrm{Hc}$ & 7.89 & & 6.92 & 6.42 \\
Halimium halimifolium & $\mathrm{Hh}$ & 35.59 & & 43.82 & 28.95 \\
Helichrysum picardii & $\mathrm{Hp}$ & 1.99 & & 1.00 & 2.54 \\
Juniperus phoenicea & $\mathrm{Jp}$ & 3.75 & & 5.05 & 4.73 \\
Lavandula stoechas & $\mathrm{Ls}$ & 4.80 & & 10.27 & 6.21 \\
Osyris alba & $\mathrm{Oa}$ & 0.00 & & 0.00 & 1.00 \\
Phillyrea angustifolia & $\mathrm{Pa}$ & 0.02 & & 0.03 & 0.04 \\
Pinus pinea & $\mathrm{Pp}$ & 0.00 & & 0.01 & 0.00 \\
Rosmarinus officinalis & $\mathrm{Ro}$ & 25.62 & & 9.99 & 20.37 \\
Stauracanthus genistoides & $\mathrm{Sg}$ & 0.62 & 0.97 & 3.98 \\
Thymus mastichina & $\mathrm{Tm}$ & 0.75 & 2.23 & 2.15 \\
Ulex australis & $\mathrm{Ua}$ & 5.17 & 6.47 & 3.93 \\
\hline
\end{tabular}

\begin{tabular}{|c|c|c|c|c|c|}
\hline \multirow{2}{*}{$\begin{array}{l}\text { b } \\
\text { Species }\end{array}$} & \multirow[b]{2}{*}{ abb } & \multicolumn{2}{|c|}{ ADULT } & \multicolumn{2}{|c|}{ RECRUIT } \\
\hline & & +2 YEARS & +8 YEARS & SEEDLING & JUVENIL \\
\hline Calluna vulgaris & $\mathrm{Cv}$ & 0.00 & 0.00 & 0.07 & 0.15 \\
\hline Cistus libanotis & $\mathrm{Cl}$ & 7.81 & 38.44 & 21.27 & 14.76 \\
\hline Cistus salvifolius & Cs & 0.00 & 0.00 & 0.01 & 0.00 \\
\hline Erica scoparia & Es & 1.79 & 0.00 & 0.00 & 0.95 \\
\hline Halimium commutatum & $\mathrm{Hc}$ & 16.44 & 7.61 & 17.11 & 15.49 \\
\hline Halimium halimifolium & $\mathrm{Hh}$ & 22.01 & 6.92 & 14.13 & 16.25 \\
\hline Helichrysum picardii & $\mathrm{Hp}$ & 5.54 & 1.85 & 1.29 & 5.12 \\
\hline Juniperus phoenicea & $\mathrm{Jp}$ & 4.56 & 1.54 & 1.15 & 2.08 \\
\hline Lavandula stoechas & Ls & 18.70 & 13.81 & 24.47 & 13.85 \\
\hline Osyris alba & $\mathrm{Oa}$ & 0.00 & 0.17 & 0.00 & 0.16 \\
\hline Phillyrea angustifolia & $\mathrm{Pa}$ & 0.03 & 0.20 & 0.11 & 0.08 \\
\hline Pinus pinea & $\mathrm{Pp}$ & 0.00 & 0.00 & 0.36 & 0.00 \\
\hline Rosmarinus officinalis & Ro & 9.35 & 24.54 & 12.51 & 17.53 \\
\hline Stauracanthus genistoides & $\mathrm{Sg}$ & 1.25 & 3.33 & 5.06 & 3.57 \\
\hline Thymus mastichina & $\mathrm{Tm}$ & 5.80 & 0.44 & 0.55 & 4.51 \\
\hline Ulex australis & Ua & 6.18 & 1.16 & 1.92 & 5.51 \\
\hline
\end{tabular}


Table S2. Results of repeated measured ANOVA for CWM traits and Functional diversity indexes between different sites, along the time. The significant level has been expressed as follows: $P<0.1^{1}$ and $P<0.05^{*}$. Abbreviations in Table 1 .

\begin{tabular}{|c|c|c|c|c|}
\hline \multirow{2}{*}{$\begin{array}{l}\text { Dependent } \\
\text { variable }\end{array}$} & & \multicolumn{3}{|c|}{ Independent variables } \\
\hline & & Site & Year & Site $x$ Yea \\
\hline & & \multicolumn{3}{|c|}{ F statistic } \\
\hline \multirow{2}{*}{ LDMCcwM } & between & 0.02 & ----- & - \\
\hline & within & & 1.22 & 0.63 \\
\hline \multirow{2}{*}{ SLAcWM } & between & 0.77 & & \\
\hline & within & $\ldots$ & 0.38 & 0.49 \\
\hline \multirow{2}{*}{ SDMCcwM } & between & 0.18 & & 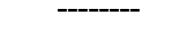 \\
\hline & WIIIIIII & 107 & 2.80 & 0.17 \\
\hline RDMCcwm & within & - & $4.96^{*}$ & 065 \\
\hline \multirow{2}{*}{ SRACWM } & between & 1.62 & & - \\
\hline & within & & 0.75 & 0.19 \\
\hline \multirow{2}{*}{ LChlcwm } & between & 3.50 & --- & - \\
\hline & within & & $4.46^{*}$ & 0.50 \\
\hline$\delta^{13} \mathrm{Ccwm}$ & between & 0.21 & & \\
\hline \multirow{2}{*}{ LNCcWM } & between & 2.69 & 0.12 & 0.93 \\
\hline & within & & 0.83 & 0.70 \\
\hline \multirow{2}{*}{ Smasscwm $\delta$} & between & 0.40 & -0 & ---- \\
\hline & within & 111 & $4.58^{*}$ & 2.37 \\
\hline Phgcwm & within & $\ldots$ & 3.031 & 0.90 \\
\hline \multirow{2}{*}{ FRich } & between & 0.20 & - & ---- \\
\hline & within & & $5.47^{*}$ & 0.68 \\
\hline FEve & within & & 0.55 & 0.81 \\
\hline \multirow{2}{*}{ FDiv } & between & 0.18 & & \\
\hline & within & ב-ב-ב-_- & 0.91 & 0.70 \\
\hline
\end{tabular}

¿ Log transform 


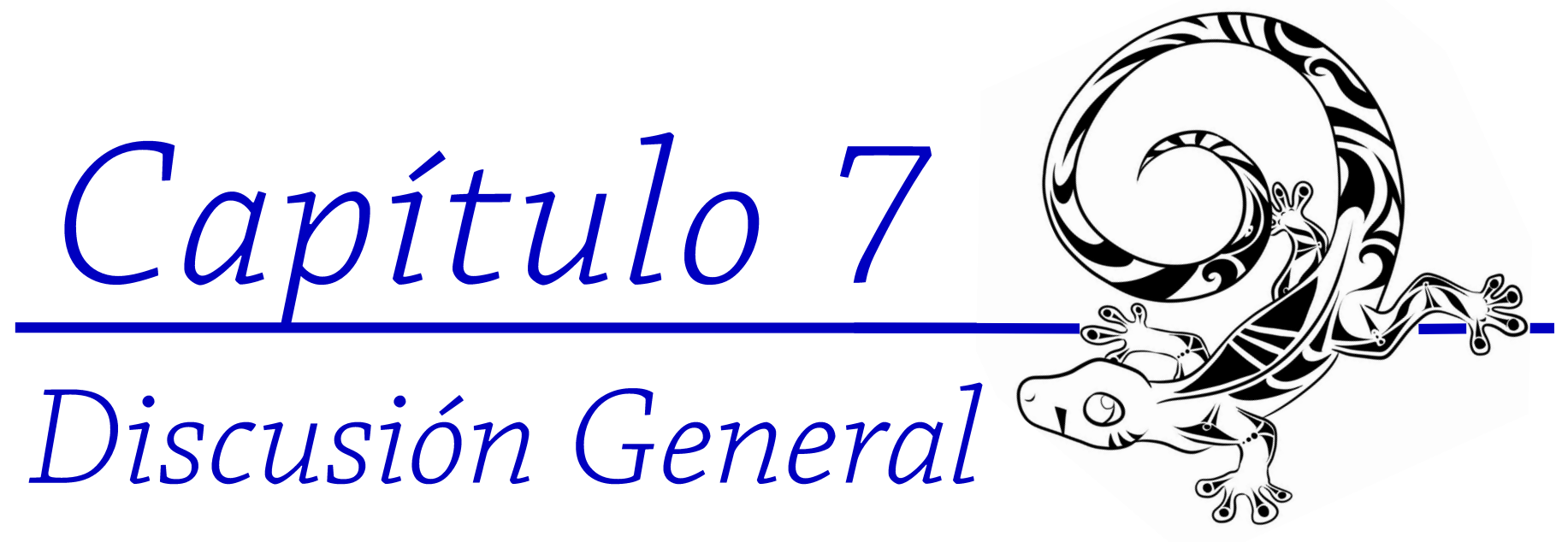

"Una colección de pensamientos debe ser una farmacia dande se encuentra remedia a tados las males"

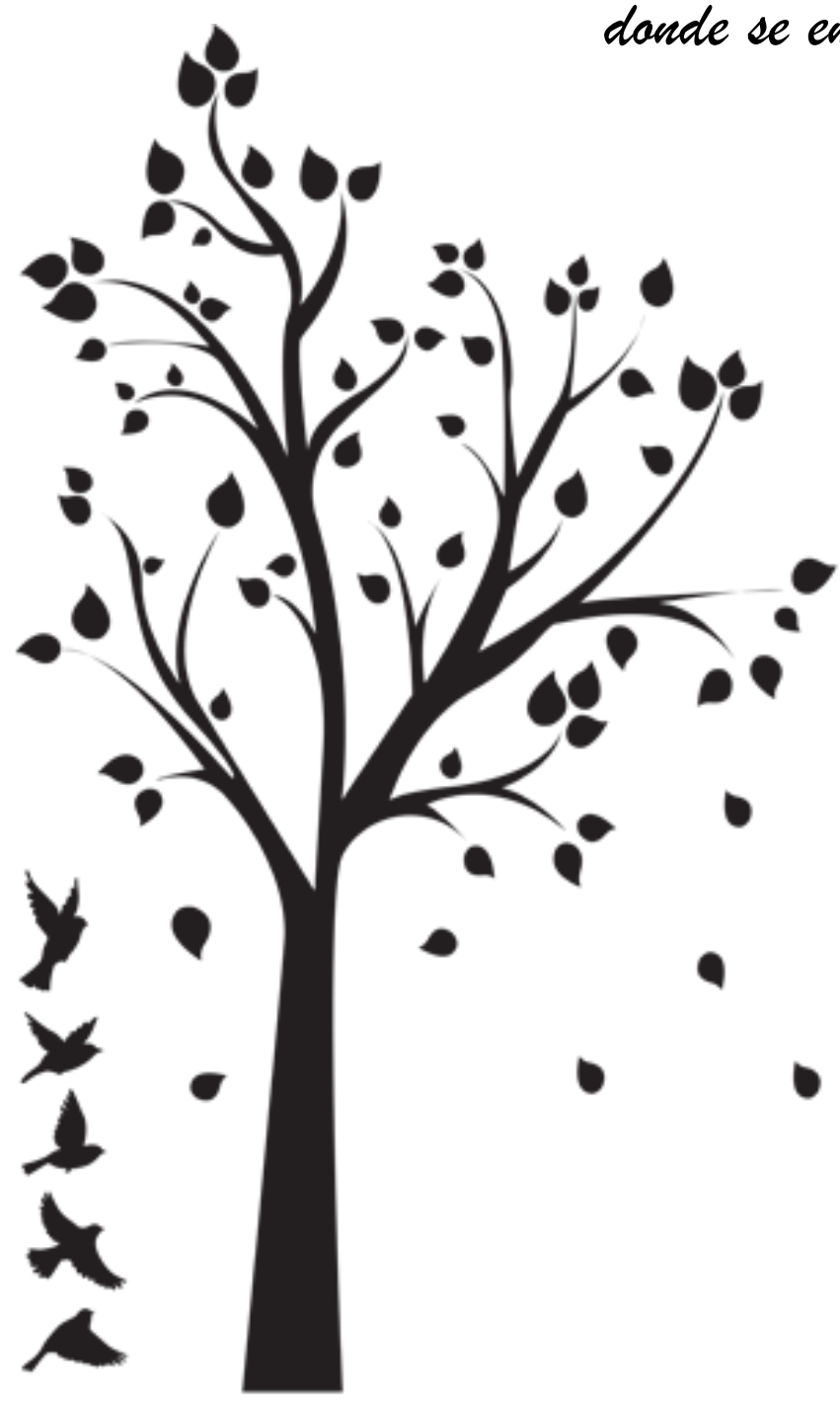

Voltaire 

A lo largo de los diferentes capítulos que componen esta tesis, se han abordado distintas cuestiones relacionadas con la ecología de las comunidades vegetales leñosas mediterráneas, confirmándose la aproximación funcional como una herramienta útil para desgranar los diferentes mecanismos que operan en el proceso de ensamblaje de estas comunidades. Se ha constatado una amplia variación funcional a nivel de toda la planta a lo largo de los gradientes ambientales explorados, apoyando los resultados de otros estudios anteriores (Cornwell y Ackerly 2009; Violle et al. 2011; Bernard-Verdier et al. 2012; Prieto et al. 2014). Los patrones encontrados en los diferentes capítulos a lo largo de diferentes niveles jerárquicos (desde el nivel celular a la comunidad; Fig. 1) muestran una distribución no aleatoria de las especies en función de sus rasgos funcionales como resultado de procesos evolutivos y de filtrado ambiental. Estos procesos determinan las estrategias funcionales predominantes en un ambiente determinado $y$, por ende, la estructura funcional de las comunidades que conforman las distintas especies (Montalvo et al 1991; Díaz y Cabido 1997; Weiher y Keddy 1999; Stubbs y Wilson 2004; Cornwell y Ackerly 2009).

En el estudio de la anatomía foliar de las especies, el peso específico foliar (LMA) estuvo condicionado tanto por el grosor como por la densidad de la hoja. A su vez, el LMA mostró diferencias en función del hábito foliar. Así, las variaciones en el grosor de la hoja en las especies caducifolias estuvieron prácticamente condicionadas por el grosor del mesófilo. En cambio, en las especies perennifolias, otros tejidos anatómicos como los vasculares y esclerenquimáticos, y en menor medida la epidermis, también condicionaron el grosor, y por ende el LMA. Estos resultados son congruentes con lo que cabría esperarse de acuerdo con el espectro de economía foliar (Wright et al. 2004). Por un lado, las especies caducifolias (potencialmente adquisitivas) emplean la mayor parte de su estructura en tejidos fotosintéticos (Pyankov 1999), permitiéndoles ser más competitivas cuando las condiciones ambientales son favorables (Givnish 2002). Por otro lado, las especies perennifolias poseen hojas más longevas que, a pesar de invertir gran parte de sus recursos en el mesófilo, también deben invertir en otras estructuras relacionadas con mecanismos de resistencia ante condiciones climáticas o bióticas (como por ejemplo, altas tasas de herbivoría) adversas (Chabot y Hicks 1982; Pammenter 1986). Así, la estructura de las hojas en especies leñosas mediterráneas está condicionada tanto por los tejidos anatómicos como por el volumen y el empaquetamiento celular (a tenor de la relación existente entre LMA y densidad). También se encontró una relación negativa entre la disponibilidad de agua y la densidad de la hoja, independientemente del hábito foliar. Estos resultados sugieren que los rasgos foliares están condicionados por la estructura anatómica de sus tejidos como consecuencia de procesos evolutivos y ambientales (Valladares et al. 2008; Liu et al. 2010).

En relación con las estrategias funcionales de las especies leñosas mediterráneas, los resultados de los diferentes capítulos indicaron una fuerte relación con el eje de variación conocido como "espectro de economía" (Wright et al. 2004; Freschet et al. 2010). Si analizamos las principales tendencias de variación funcional de todas las especies muestreadas en los diferentes estudios que componen esta tesis doctoral (Fig. 2), encontramos un eje principal en torno al cual se distribuyen las diferentes especies en función de sus rasgos funcionales. En un extremo del eje predominan las especies caducifolias (p. ej. Ulmus minor, Alnus glutinosa y Quercus 

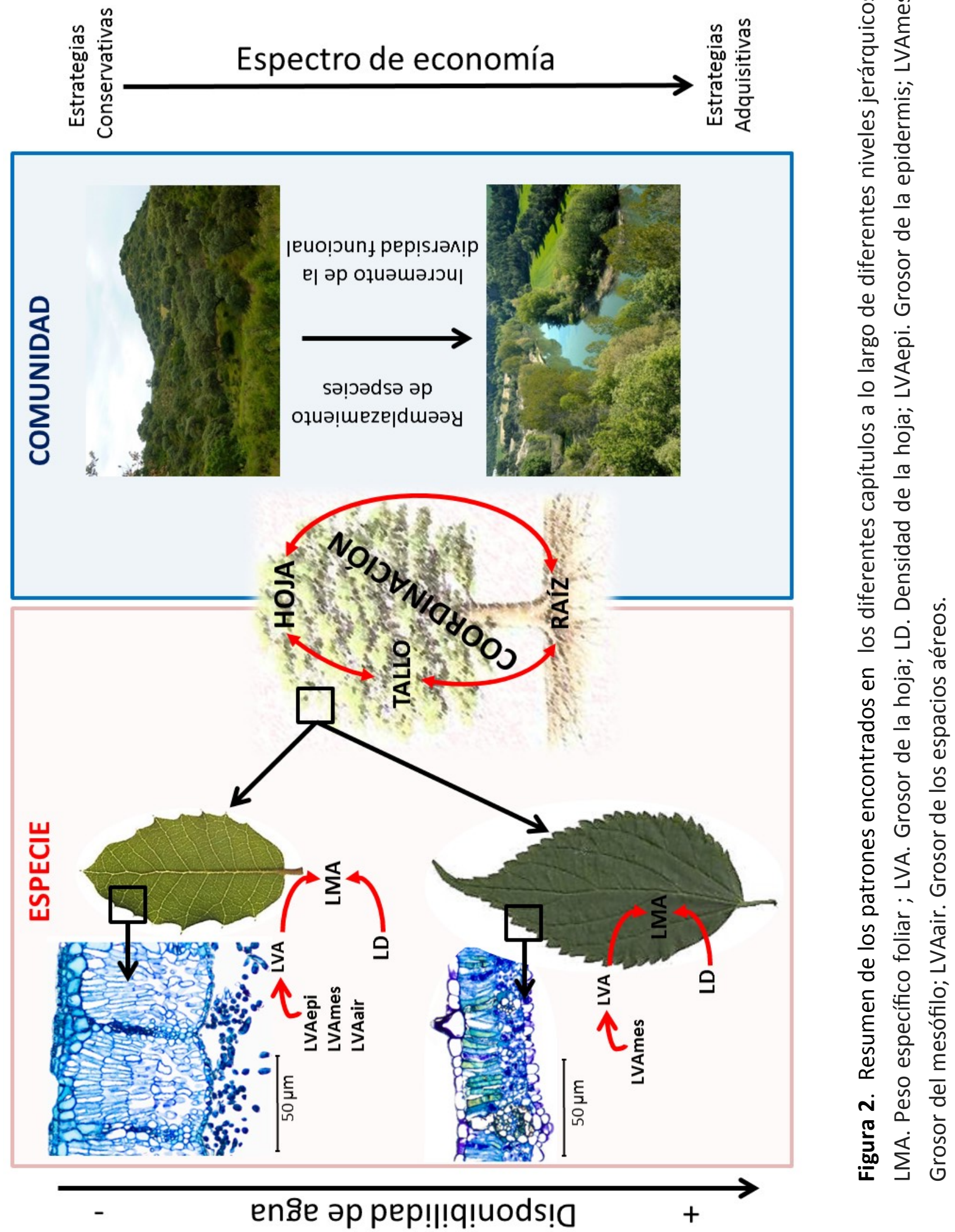


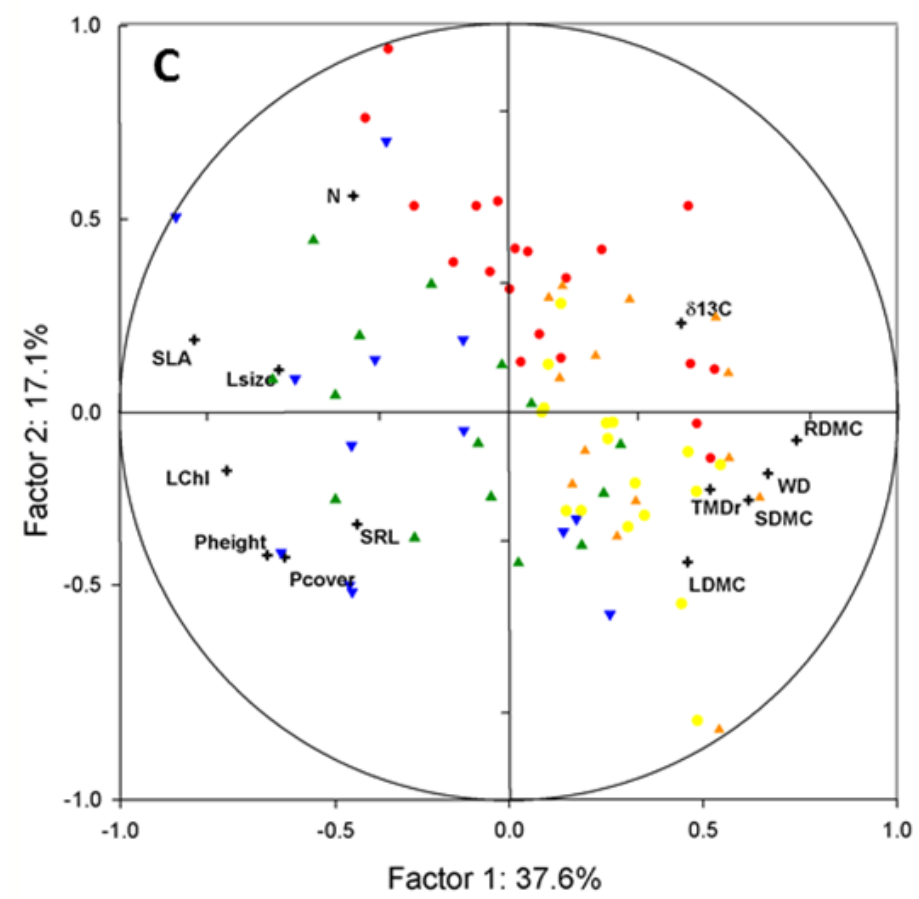

Figura 2. Análisis de componentes principales (PCA), donde se aprecia la distribución de los rasgos funcionales a lo largo del eje principal acorde con el espectro de economía. Se han representado13 rasgos funcionales muestreados en un total de 91 especies (18 en P. N. Los Alcornocales -en verde-, 14 en el P.N. de Doñana -en naranja , 23 en el P.N. de Cabo de Gata -en rojo , 18 en Sierra Morena -en amarillo y 18 en los afluentes del río Bejarano -en azul-). SLA. Área específica foliar; Lsize. Área foliar; LDMC. Contenido de materia seca en hoja; N. Concentración de nitrógeno en hoja; LChl. Contenido de clorofila en hoja; $\zeta^{13} \mathrm{C}$. Fracción isotópica de carbono; WD. Densidad de la madera; SDMC. Contenido de materia seca en tallo; SRL. Longitud específica radicular; RDMC. Contenido de materia seca en raíz; TMDr. Densidad de la raíz; Pheight. Altura de la planta; Pcover. Cobertura de la planta.

canariensis) así como algunas perennifolias presentes en las zonas más húmedas (p. ej. Hedera helix y Rhododendron ponticum). En general, se trata de especies de elevado porte, con valores más elevados de área específica foliar y radicular (SLA y SRA), así como una mayor concentración foliar de clorofila y nitrógeno. Este síndrome es típico de especies de crecimiento más rápido que invierten en tejidos poco densos, de vida más corta y con una elevada tasa de renovación de nutrientes (Reich et al.1992; Withington et al. 2006; Villar et al. 2006). En el otro extremo del gradiente ambiental se encuentran especies de porte arbustivo (p. ej. Cistus albidus, Cistus libanotis, Fumana spidula y Halimium commutatum) o arbóreo-arbustivo (p. ej. Juniperus phoenicea, Quercus ilex y Quercus coccifera), siendo la encina (Quercus ilex) la única especie arbórea presente en este extremo del eje. Estas especies presentaron tejidos más densos y gruesos, con valores elevados de materia seca y de la relación isotópica del $\mathrm{C}^{13}$, características típicas de especies de crecimiento lento con menores tasas de inversión y renovación de nutrientes (Kembel y Cahill 2011; Baraloto et al. 2010). Así pues, los resultados obtenidos en los diferentes capítulos sugieren que las especies leñosas mediterráneas se pueden ordenar según un eje de especialización relacionado con el uso de los recursos, que definen un compromiso entre la adquisición y conservación de los mismos en función de su disponibilidad en el medio. 
Por otro lado, se analizó el grado de correlación entre rasgos funcionales pertenecientes a diferentes órganos de la planta (capítulo 3), encontrándose una fuerte coordinación entre ellos. Estos resultados son congruentes con la idea de que los espectros de economía de la hoja, del tallo y de la raíz están íntimamente ligados, respaldando así la existencia de un "espectro de economía a nivel de toda la planta". Estos resultados apoyan los obtenidos en otros estudios previos (Ryser 1996; Reich et al. 1998; Ishida et al. 2008; Freschet et al. 2010; Hérnandez et al. 2010; Liu et al. 2010; Méndez-Alonzo et al. 2012), pero contrastan con otros que no detectaron coordinación entre los rasgos funcionales de los diferentes órganos (Tjoelker et al. 2005; Baraloto et al. 2010; Fortunel et al. 2012). Estas incongruencias pueden deberse, entre otros factores, al tipo de ecosistema estudiado, a los rasgos funcionales analizados, al estadío sucesional o a la escala de estudio (Kembel \& Cahill 2011; Funk y Conrwell 2013; Silva et al. 2015). Centrándonos en los resultados de estudios llevados a cabo con especies leñosas en gradientes ambientales locales, encontramos que en ecosistemas a priori menos estresantes en relación a la disponibilidad de recursos del medio (por ejemplo en ecosistemas tropicales; Baraloto et al. 2010 y Fortunel et al. 2012), la falta de coordinación entre órganos puede ser el resultado de compensar estrategias contrastadas relacionadas con el rápido crecimiento de la planta (resultado de la competencia) y la supervivencia, optimizando la inversión de recursos entre los diferentes órganos. Por otro lado, en los gradientes ambientales analizados en climas más adversos (por ejemplo en climas áridos; Liu et al. 2010), parece existir mayor coordinación entre los rasgos funcionales de los distintos órganos, posiblemente como consecuencia de una convergencia funcional de dichos rasgos que les confieran una mayor tolerancia/resistencia a dichas limitaciones abióticas, predominando la necesidad de supervivencia frente a la de crecimiento (capítulo 3).

Nuestros resultados, tanto a nivel local como regional, sugieren que la estructura funcional de la comunidad está condicionada principalmente por la disponibilidad de agua en el suelo, apoyando estudios similares en comunidades de especies leñosas de clima mediterráneo (Cornwell y Ackerly 2009). Nuestros resultados mostraron también que esta variación de la estructura funcional de la comunidad a lo largo del gradiente de humedad fue debida principalmente a un proceso de sustitución de especies más que a variaciones en la plasticidad fenotípica de las especies constituyentes. En este sentido, la naturaleza dual de los filtros ambientales es particularmente evidente a lo largo del gradiente de estrés-productividad (como es nuestro caso de estudio), en el que por un lado el establecimiento de las especies está limitado fisiológicamente en un extremo, y por la competencia en el otro (Grime 1979). Así, las especies que predominan en las zonas más secas poseen rasgos funcionales característicos de estrategias conservativas, como resultado de las limitaciones impuestas por la falta de agua. En cambio, en las zonas más húmedas, dominan especies con una estrategia fundamentalmente adquisitiva como resultado de un efecto de competencia por la luz (ver Gross 2013 y las referencias incluidas en ese artículo). Esto a su vez explicaría el por qué, a diferencia de otros estudios (Westoby 1998; Golodets et al. 2009; Laughlin et al. 2010; Silva et al. 2015), la altura de la planta se relaciona con el eje representativo de la economía foliar, es decir en las comunidades dominadas por especies adquisitivas las plantas son más altas para competir mejor por la luz.

La sustitución de especies a lo largo del gradiente ambiental fue debida a los procesos de filtrado que limitan el rango fenotípico de las especies, permitiéndonos observar cierta convergencia funcional de acuerdo con las 
estrategias exitosas en la captación de recursos en función de la disponibilidad hídrica. Estos patrones fueron muy marcados, tanto a nivel local (capítulo 4) como regional (capítulo 5), especialmente a nivel de comunidad; con comunidades claramente representadas por estrategias conservativas en las zonas más secas y estrategias adquisitivas en las zonas más húmedas. Sin embargo, si comparamos ambos extremos del gradiente ambiental, observamos situaciones contrastadas. En las condiciones más estresantes (con menor disponibilidad de agua) se restringe el conjunto de rasgos viables para esas condiciones ambientales, promoviendo una reducción del espacio funcional (Kleydon y Mooney 2000). Por el contrario, en las zonas húmedas, el proceso de exclusión competitiva provocado por la falta de luz no es tan drástico, permitiendo la coexistencia de algunas especies (minoritarias) con tendencias más conservativas (por ejemplo Pistacia lentiscus o Cistus salvifolious), que pueden aprovechar los huecos producidos por las perturbaciones. Por lo tanto, a lo largo de los diferentes capítulos observamos que el ensamblaje de las comunidades leñosas mediterráneas es el resultado de la combinación de procesos ecológicos y filogenéticos que actúan sobre la evolución y distribución de los rasgos funcionales, principalmente como consecuencia del filtrado ambiental y la exclusión competitiva (Webb et al. 2002; Cavender-Bares et al. 2006).

Respecto al análisis temporal (capítulo 6), queda patente la capacidad de resiliencia funcional de las especies de matorral mediterráneo ante un evento climático extremo (ver también Lloret et al. 2016). Las comunidades estudiadas mostraron una elevada recuperación de los valores funcionales iniciales a pesar de los cambios observados en la estructura y composición de las mismas tras el evento climático. En este sentido, la desaparición de algunas especies (p.ej. Calluna vulgaris) tras el evento dio lugar a una caída inicial de la riqueza funcional, sin consecuencias en el espacio funcional que se mantuvo constante, como indica la invariabilidad de la equidad y divergencia funcional de las comunidades a lo largo del tiempo (Mason et al. 2005). Sin embargo, las comunidades con mayor divergencia funcional (mayor abundancia de especies con valores de rasgo funcional extremos; Villager et al., 2010) presentaron mayor cambio en la composición de especies, a pesar de no sufrir variaciones a lo largo del tiempo en lo que respecta a la divergencia funcional. Probablemente esto sucedió así porque las especies fueron reemplazadas por otras con propiedades funcionales similares (Naeem 1998; Walker et al, 1999), por ejemplo Halimium halimifolium y Rosmarinus officinalis, fueron parcialmente reemplazadas por Cistus libanotis y Lavandula stoechas (especies funcionalmente cercanas). Los resultados de este capítulo ponen de manifiesto la alta capacidad de recuperación funcional que poseen las comunidades de matorral mediterráneo frente a perturbaciones, algo que ha sido ampliamente descrito frente a incendios forestales (Díaz-Delgado et al 2002; Lloret y Zedler 2009), y permiten ampliar su significado para otras fuentes de perturbación ambiental tales como aquellas derivadas de fenómenos climáticos extremos. Además, hay que destacar que estos mecanismos de resiliencia no implican necesariamente que la misma composición de especies se mantenga tras el evento perturbador.

Por último, también se pueden destacar dos temas interesantes, aunque no hayan sido el objetivo principal de los capítulos de esta tesis: la importancia del tamaño de semilla y el nivel de estudio considerado.

En relación al peso de la semilla, se han encontrado varios indicios de la relevancia que puede tener este rasgo reproductivo en las comunidades leñosas mediterráneas (capítulos 3 y 5). Se apreció que en condiciones 
ambientales más estresantes (con menor disponibilidad hídrica) las especies dominantes tendieron a presentar semillas más grandes (de mayor peso). Por un lado, existió una relación positiva a nivel de comunidad (CWM) entre el aumento del peso de la semilla y los rasgos asociados a estrategias conservativas en las comunidades de Sierra Morena (capítulo 3). Por otro lado, en el estudio llevado a cabo en Doñana (capítulo 6) se observó que el peso de la semilla fue el único rasgo funcional que se incrementó ocho años después del episodio extremo de sequía intensa que aconteció en el 2005, como resultado de un mayor reclutamiento de las especies con mayor peso de semilla. Estos resultados apoyan el modelo de tolerancia-fecundidad propuesto por Muller-Landau (2010), según el cual las especies de semilla pequeña serán favorecidas en los ambientes más productivos, mientras que las especies de semilla grande serán más abundantes en hábitats estresantes. Las semillas de mayor tamaño producen a su vez plántulas más vigorosas con mayor desarrollo de la raíz, permitiéndoles capturar más agua en el suelo en condiciones de menor disponibilidad hídrica (Westoby et al. 2002; Quero et al. 2007; Pérez-Ramos et al. 2010). A nivel de comunidad, la aparente covariación entre los rasgos morfológicos y reproductores sugiere que una coordinación de las estrategias relacionadas con el espectro de economía y la tolerancia-fecundidad podría ser la combinación más exitosa en especies leñosas mediterráneas a lo largo del gradiente ambiental.

El nivel de estudio elegido es importante al comparar resultados de diferentes trabajos. Los resultados de los diferentes capítulos mostraron que la escala espacial (capítulo 3), el hábito foliar (capítulo 2) o los rasgos funcionales seleccionados (capítulo 6) pueden condicionar los resultados, dificultando la comparación con otros estudios previos. Por ejemplo, la falta de coordinación entre órganos detectada en hábitats similares en el estudio de Sierra Morena o la inexistencia de un patrón relativo al espectro de economía en el estudio de Doñana sugieren que en un entorno similar (con condiciones abióticas homogéneas), la diversificación de estrategias exitosas está limitada al rango de variación funcional que sea viable para persistir bajo esas condiciones determinadas. Esto puede dar lugar a resultados difusos y en ocasiones difíciles de interpretar. A tenor de estos resultados, es importante tener en cuenta que la variable que condiciona el gradiente ambiental de nuestro estudio sea limitante y por tanto determinante en la distribución de los rasgos a analizar. A su vez, en el capítulo 6 apreciamos cómo la diversidad funcional puede variar en función de los rasgos seleccionados y del ambiente. Así, los rasgos funcionales de ciertos órganos pueden mostrar más diversidad que otros en función del ambiente (por ejemplo los rasgos funcionales de hoja en comparación con los de la raíz, en ambientes secos y húmedos). Esto pone de manifiesto la necesidad de aumentar el conocimiento en este campo, que permita determinar qué rasgos funcionales son los más adecuados para comparar la diversidad funcional de determinados ecosistemas y grupos funcionales.

La ecología funcional se ha aplicado a las comunidades leñosas mediterráneas, en una variedad de niveles de organización (desde la anatomía de la hoja, los diferentes órganos, la planta completa, la población y la comunidad), y escalas espaciales (local y regional), mostrándose como una herramienta muy útil en el análisis de la ecología de estos ecosistemas. Esta aproximación funcional nos ha permitido desgranar tanto las estrategias funcionales de las distintas comunidades leñosas mediterráneas como los patrones de ensamblaje de especies a lo largo de los diferentes gradientes ambientales y escalas analizadas. Es importante también destacar el esfuerzo que nos ha 
supuesto trabajar con rasgos funcionales a nivel de toda la planta, permitiéndonos por un lado generalizar en las relaciones de las distintas dimensiones funcionales, y por otro comprender mejor los diferentes procesos que tienen lugar a nivel de toda la planta en especies leñosas mediterráneas. Especialmente, me gustaría enfatizar en el papel de los rasgos funcionales de la raíz por el sesgo existente de los mismos respecto a los rasgos aéreos, no sólo en lo que respecta a las plantas leñosas mediterráneas sino en la literatura científica en general. En definitiva, si bien es difícil hacer generalizaciones desde el punto de vista funcional sobre los patrones de variación y la dinámica de las comunidades vegetales por la propia idiosincrasia de cada sistema, el presente cuerpo de tesis ofrece una base de conocimiento consistente de los ecosistemas mediterráneos y de cómo sus componentes operan a lo largo de diferentes gradientes ambientales.

\section{Bibliografía}

Baraloto C, Paine CE, Poorter L., Beauchene J, Bonal D, Domenach AM, Hérault B, Patiño S, Roggy JC, Chave J (2010). Decoupled leaf and stem economics in rain forest trees. Ecology Letters, 13: 1338-1347.

Cavender-Bares J, Keen A, Miles B (2006). Phylogenetic structure of Floridian plant communities depends on taxonomic and spatial scale. Ecology, 87: S109-S122.

Chabot BF, Hicks DJ (1982). The ecology of leaf life spans. Annual Review of Ecology and Systematics, 13: $229-259$.

Cornwell WK, Ackerly DD (2009). Community assembly and shifts in plant trait distributions across an environmental gradient in coastal California. Ecological Monographs, 79: 109-126.

Díaz S, Cabido M (2001). Vive la difference: plant functional diversity matters to ecosystem processes. Trends in Ecology \& Evolution, 16: 646-655.

Bernard-Verdier M, Navas ML, Vellend M, Violle C, Fayolle A, Garnier E (2012). Community assembly along a soil depth gradient: contrasting patterns of plant trait convergence and divergence in a Mediterranean rangeland. Journal of Ecology, 100: $1422-1433$.

Díaz-Delgado R, Lloret F, Pons X, Terradas J (2002). Satellite evidence of decreasing resilience in Mediterranean plant communities after recurrent wildfires. Ecology, 83: 2293-2303.

Fortunel C, Fine PV, Baraloto C (2012). Leaf, stem and root tissue strategies across 758 Neotropical tree species. Functional Ecology, 26: 1153-1161.

Freschet GT, Cornelissen JHC, van Logtestijn RSP, Aerts R (2010). Evidence of the "plant economics spectrum" in a subarctic flora. Journal of Ecology, 98: 362-373.

Funk JL, Cornwell WK (2013). Leaf traits within communities: context may affect the mapping of traits to function. Ecology, 94: 1893-1897

Givnish TJ (2002). Ecological constraints on the evolution of plasticity in plants. Evolutionary Ecology, 16: $213-242$.

Golodets C, Sternberg M, Kigel J (2009). A community level test of the leaf height seed ecology strategy scheme in relation to grazing conditions. Journal of Vegetation Science, 20: 392-402. 
Grime JP (1979). Plant strategies and vegetation processes. Wiley, Chichester.

Hernández El, Vilagrosa A, Pausas JG, Bellot J (2010). Morphological traits and water use strategies in seedlings of Mediterranean coexisting species. Plant Ecology, 207: 233- 244.

Ishida A, Nakano T, Yazaki K et al. (2008). Coordination between leaf and stem traits related to leaf carbon gain and hydraulics across 32 drought-tolerant angiosperms. Oecologia, 156: 193-202.

Kembel SW, Cahill Jr JF (2011). Independent evolution of leaf and root traits within and among temperate grassland plant communities. PloS one, 6: e19992.

Kleidon A, Mooney HA (2000). A global distribution of biodiversity inferred from climatic constraints: results from a processbased modelling study. Global Change Biology, 6: 507-523.

Laughlin DC, Leppert JJ, Moore MM, Sieg CH (2010). A multi-trait test of the leaf-height-seed plant strategy scheme with 133 species from a pine forest flora. Functional Ecology, 24: 493-501.

Liu G, Freschet GT, Pan X, Cornelissen JHC, Li Y, Dong M (2010). Coordinated variation in leaf and root traits across multiple spatial scales in Chinese semi-arid and arid ecosystems. NewPhytologist, 188: 543-553.

Lloret F, de la Riva E, Pérez-Ramos I, Marañón T, Saura-Mas S, Díaz- Delgado R, Villar R (2016). Climatic events inducing die-off in Mediterranean shrublands: are species responses related to their functional traits? Oecologia, doi:10.1007/s00442016-3550-4.

Lloret F, and Zedler PH (2009). The effect of forest fire on vegetation. (eds. Cerda, A. and Robichaud, P.R.) Fire effects on soils and restoration strategies, pp. 257-295.

Mason N W, Mouillot D, Lee WG, Wilson JB (2005). Functional richness, functional evenness and functional divergence: the primary components of functional diversity. Oikos, 111: 112-118.

Méndez-Alonzo R, Paz H, Zuluaga RC, Rosell JA, Olson ME (2012). Coordinated evolution of leaf and stem economics in tropical dry forest trees. Ecology, 93: 2397-2406

Montalvo J, Casado MA, Levassor C, Pineda FD (1991). Adaptation of ecological systems: Compositional patterns of species and morphological and functional traits. Journal of Vegetation Science, 2: 655-666.

Muller-Landau HC (2010). The tolerance-fecundity trade-off and the maintenance of diversity in seed size. Proceedings of the National Academy of Sciences of the United States of America, 107: 4242-4247.

Naeem S (1998). Species Redundancy and Ecosystem Reliability. Conservation Biology, 12: 39-45.

Pammenter NW, Drennan PM, Smith VR (1986). Physiological and anatomical aspects of photosynthesis of two Agrostis species at a sub-antarctic island. New Phytologist, 102: 143-160.

Pérez-Ramos IM, Gómez-Aparicio L, Villar R, Garcia LV, Marañón T (2010). Seedling growth and morphology of three oak species along field resource gradients and seed mass variation: a seedling age-dependent response. Journal of Vegetation Science, 21: 419-437

Prieto I, Roumet C, Cardinael R, et al. (2015). Root functional parameters along a land-use gradient: evidence of a communitylevel economics spectrum. Journal of Ecology, 103: 361-373. 
Pyankow VI, Kondratchuk AV, Shipley B (1999). Leaf structure and specific leaf mass: The alpine desert plants of the Eastern Pamirs, Tadjikistan. New Phytologist, 143: 131-142.

Quero JL, Villar R, Marañon T, et al. (2007). Seed mass effects in four mediterranean Quercus species (Fagaceae) growing in contrasting light environments. American Journal of Botany, 94: 1795-1803.

Reich PB, Walters MB, Ellsworth DS (1992). Leaf life-span in relation to leaf, plant, and stand characteristics among diverse ecosystems. Ecological Monographs, 62: 365-392.

Reich PB, Walters MB, Tjoelker MG, Vanderklein D, Buschena C (1998). Photosynthesis and respiration rates depend on leaf and root morphology and nitrogen concentration in nine boreal tree species differing in relative growth rate. Functional Ecology, 12: 395-405.

Ryser P (1996). The importance of tissue density for growth and life span of leaves and roots: a comparison of five ecologically contrasting grasses. Functional Ecology, 10: 717- 723.

Silva MAM, Pinto ADVF, do Nascimento LM, Lins-e-Silva ACB, de Lima ALA, Rodal MJN (2015). Does the plant economics spectrum change with secondary succession in the forest? Trees, 29: 1521-1531

Stubbs WJ, Wilson JB (2004). Evidence for limiting similarity in a sand dune community. Journal of Ecology, 92: 557-567.

TjoelkerMG, Craine JM,Wedin D, Reich PB, Tilman D (2005). Linking leaf and root trait syndromes among 39 grass- land and savannah species. New Phytologist, 167: 493-508.

Valladares F, Tena D, Matesanz S, et al. (2008). Functional traits and phylogeny: What is the main ecological process determining species assemblage in roadside plant communities? Journal of Vegetation Science, 19: 381-392.

Villar R, Robleto JR, De Jong Y, Poorter H (2006). Differences in construction costs and chemical composition between deciduous and evergreen woody species are small as compared to differences among families. Plant, Cell and Environment, 29: 1629-1643.

Walker B, Kinzig A, and Langridge J (1999). Original articles: plant attribute diversity, resilience, and ecosystem function: the nature and significance of dominant and minor species. Ecosystems, 2: 95-113.

Webb CO, Ackerly DD, McPeek M, Donoghue MJ (2002). Phylogenies and community ecology. Annual Review of Ecology and Systematics, $33:$ 475-505.

Weiher E, Keddy P (1999). Ecological assembly rules: perspectives, advances, retreats. Cambridge University Press, Cambridge, UK.

Westoby M (1998). A leaf-height-seed (LHS) plant ecology strat- egy scheme. Plant and Soil, 199: 213-227.

Westoby M, Falster DS, Moles AT, et al. (2002). Plant ecological strategies: some leading dimensions of variation between species. Annual Review of Ecology, Evolution, and Systematics, 33: 125-159.

Withington JM, Reich PB, Oleksyn J, Eissenstat DM (2006). Comparisons of structure and life span in roots and leaves among temperate trees. Ecological Monographs, 76: 381-397.

Wright IJ, Reich PB, Westoby M, et al. (2004). The worldwide leaf economics spectrum. Nature, 428: 821-827. 



\section{Conclusiones generales}

I. La variación del peso específico foliar (LMA) se debe tanto a cambios en la densidad (LD) como en el grosor (LVA) de la hoja (Capítulo 2).

II. La variación del grosor (LVA) en las hojas de especies leñosas mediterráneas está condicionado principalmente por el grosor del mesófilo, especialmente en las especies caducifolias. En las especies perennifolias otros tejidos anatómicos como los vasculares y esclerenquimáticos, y en menor medida la epidermis, también condicionan el grosor (Capítulo 2).

III. El incremento de LMA con la disminución de la disponibilidad de agua se debe principalmente a un incremento en la densidad foliar (Capítulo 2).

IV. Existe una elevada coordinación funcional entre los diferentes órganos (hoja, tallo y raíz) en las plantas leñosas mediterráneas, tanto a nivel de especie como a nivel de comunidad. Esta coordinación sigue un patrón acorde con el eje de variación conocido como "espectro de economía" (Capítulo 3).

V. Los patrones de coordinación funcional encontrados a lo largo del gradiente ambiental desaparecen o se hacen más débiles cuando solo se tiene en consideración las especies de un determinado ambiente (Capítulo 3).

VI. La disponibilidad hídrica es el principal factor ambiental condicionante de la composición funcional de las comunidades leñosas mediterráneas a lo largo del gradiente ambiental (Capítulo 4).

VII. Las variaciones de la estructura funcional de las comunidades a lo largo del gradiente ambiental son el resultado de un proceso de reemplazamiento de especies, teniendo los cambios de abundancia o la variabilidad intraespecífica de las especies un efecto mucho menor en la variación de la estructura funcional (Capítulo 4).

VIII. A nivel regional, al igual que a nivel local, la aridez condiciona la estructura funcional (tanto la composición como la diversidad) de las comunidades leñosas (Capítulo 5).

IX. Las comunidades con una mayor disponibilidad de agua presentan niveles más altos de diversidad funcional, posiblemente como resultado de procesos de diferenciación de nicho (Capítulo 5). 
X. La diversidad funcional de las comunidades leñosas depende en gran medida de la dimensión funcional seleccionada, así las zonas áridas mostraron elevada diversidad funcional para los rasgos foliares, a pesar de su baja diversidad funcional a nivel de toda la planta (Capítulo 5).

XI. Las comunidades de matorral mediterráneo presentan una elevada capacidad de resiliencia funcional frente a las perturbaciones ambientales, si bien estos mecanismos de resiliencia funcional no implican necesariamente la continuidad en la composición de especies (Capítulo 6).

XII. Las comunidades con valores más elevados en el contenido de materia seca en raíz y tallo y menor área específica radicular presentaron mayor resistencia ante la perturbación ambiental, mientras que las comunidades con valores más elevados de clorofila presentaron mayor capacidad de resiliencia (Capítulo 6). 


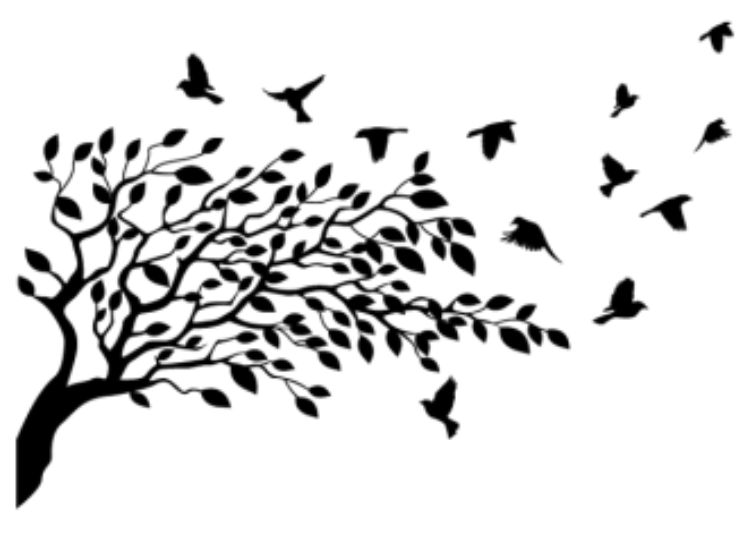

\author{
"Realmente soy un soĩador práctica; mis sueños na \\ san bagatelas en el aire. La que ya quiera es convertir \\ mis sueños en realidad"
}

Mahatma Gandhi

\title{
Agradecimientos
}

Una de la cosas que tenía clara cuando terminé la carrera era que no me quería dedicar a la investigación, fue por ello que en cuanto terminé la licenciatura me puse a trabajar para poder financiar un par de masters (Consultoría ambiental y Restauración de ecosistemas) con la intención de encaminarme laboralmente al sector empresarial, específicamente, deseaba orientar mi carrera profesional hacia el mundo de las empresas constructoras (en ese momento todavía no se hablaba de crisis, ni burbujas inmobiliarias). Así fue como terminé cogiendo una oferta de prácticas en empresa para la empresa constructora OHL. Si bien dicha oferta especificaba que el trabajo se basaría en ordenar y analizar bases de datos en colaboración con la Universidad Complutense, yo veía la oportunidad de trabajar para una de las empresas más grandes de España, con el incentivo de que además pagaban (esta parte era importante porque hacía tiempo que me había emancipado). De esta manera, y sin quererlo, acabé trabajando de lleno en el grupo de investigación de Luis Balaguer. A pesar de que en mis comienzos no entendía muy bien para qué servía analizar tanto dato, como siempre he sido bastante pragmático (especialmente en cuanto al mundo laboral se refiere) me centraba en hacer bien mi trabajo, principalmente porque me estaban pagando y porque la persona que hizo las practicas el año anterior había sido contratado en OHL... lástima que en esos meses ya sí se empezaba a escuchar de manera recurrente las palabras "deceleración económica" (traducción, OHL no me iba a contratar y empezaba la crisis). La cuestión fue que poco a poco me fue entrando el gusanillo de la investigación, en gran parte por culpa de Luis; a los que le conocían no hace falta explicar por qué, para los que no tuvieron la suerte de conocerle solo decir que era una persona arrolladora capaz de transmitir su alegría y su pasión por la ciencia de una manera inexplicable (a lo mejor se podría tratar de explicar, pero tampoco se trata de extender más los agradecimientos). También debo agradecerle a Luis que convenciera a Rafa para que me contratara, porque si no estas líneas no hubieran sido posibles. En todo este proceso de viraje al lado oscuro, influyó también la relación con varias personas que me ayudaron enormemente y me enseñaron cómo desarrollar esta nueva actividad profesional; Mariló, Míguel e Iñaki. Durante mis primeros meses trabajando en "la Complu", además apareció una persona muy especial para mí y con su visión de la vida me ayudó a apreciar más este trabajo; Rocío. Ella ha sido como mi hermana de ciencia y quiero aprovechar estas páginas para agradecerle todo su apoyo, ayuda, alegría y especialmente por aguantar mis bajones. También dar las gracias al resto del grupo con los que he podido disfrutar congresos, comidas, cervezas y risas: Ana, Caty, Peri, Juanma, Juan, Sandra, Irene, Agustina, Adri (si me dejo a alguien le pido disculpas).

Tras acabarse la financiación en la Complu y varios años deambulando por el desierto (de las empresas privadas y contratos precarios), tuve la suerte de que Rafa me diera la oportunidad de volver a dedicarme a la investigación en la Universidad de Córdoba. Estos cuatro últimos años no han sido fáciles para mí, especialmente por dos motivos: el estar separado de mi mujer (no lo he llevado nada bien) y la presión (autoinflingida) de publicar a toda costa para tratar de sortear el próximo desierto. Sin embargo, he tenido grandes momentos con la gente del 
departamento de ecología de Córdoba que me han ayudado a llevar mejor mi situación personal. En este sentido agradecer el tiempo compartido especialmente durante la comidas con Joaquín y Jose (durante un par de años éramos los habituales) en las que sobre todo nos hemos reído mucho y hemos arreglado el mundo poniéndolo patas arriba; creo que entre otras personalidades no ha quedado líder político nacional o extranjero sin mofa (tampoco lo ponen complicado). También me gustaría agradecer en especial a las personas que me han dado cobijo en su casa durante el último año, Rafa Obregón, Manolo y Juan Carlos. Gracias por abrirme las puertas de vuestras casas y vuestras familias y gracias por todos los buenos ratos que hemos compartido. También agradecer a mi compañera de despacho, Bárbara, por las conversaciones (y desahogos) que hacían más amenas las mañanas. Agradecer estos años a otros compañeros, como Salva que fue el primero en llevarme a tomar café por las mañanas y a jugar al futbol por las tardes, Pilar que entre otras cosas me llevó a su pueblo a rescatar renacuajos (anécdota de esas que no se olvida), o Esther que me da la vida con cada papeleo que tengo que tramitar, y otros compañeros con los que quizás he compartido menos pero también he tenido buenas conversaciones, Juan, Diego, Ana... en general gracias a todo el departamento por acogerme tan bien este tiempo.

La relación con el director de tesis suele ser compleja (no digamos si son tres), algo así como amor-odio, seguramente por la extraña relación laboral en la que tu jefe es también tu amigo. En este sentido y a pesar de algún que otro rifirrafe he tenido bastante suerte. Agradecerles a Rafa, Teo y Nacho su comprensión, su apoyo, su especial dedicación durante estos cuatro años. Agradecer a Rafa su actitud, siempre sosegado, me ha escuchado y me ha guiado durante este periodo de mi vida; Teo siempre positivo, cordial y un gran conocedor de la ecología; Nacho, es el rock\&roll (termino muy utilizado a nivel culinario), el inconformismo, la exigencia. Entre los tres han conseguido que esta tesis sea posible y lo que es más importante me han hecho madurar como persona y como profesional.

Me gustaría destacar otras personas que me han ayudado a lo largo de la tesis. Empezar por dos pilares fundamentales, Carmen y Manolo (otra vez), especialmente por su ayuda en el campo y en el laboratorio, siempre con una gran disposición y muy buen rollo -da gusto trabajar con vosotros-. A Miguel Verdú, por acogerme en su despacho y enseñarme los análisis filogenéticos, dedicándome su tiempo de forma altruista. A la gente del CREAF Paco y Sandra, ha sido un placer y una gran experiencia trabajar con ellos. Al resto de coautores que han colaborado y me han ayudado en la elaboración de los diferentes artículos: Ambra, Niels, Hendrik, Ubera, Ricardo, Cyrille.

A pesar de haber empezado los agradecimientos por el ámbito profesional, gran parte de todos mis méritos se los debo a mi familia. Es un hecho que ninguno sabe ni comprende exactamente a qué me dedico (quitando a lo mejor a mi mujer que es la que más directamente lo sufre), y lo más maravilloso es que a pesar de dicha incomprensión profesional todos me apoyan con mi trabajo. Mi familia me ha cuidado a lo largo de toda mi vida, se han preocupado por mí y me han forjado el carácter. De forma jerárquica empezar dando las gracias a mis abuelos Segundo, Teresa, Luciño y Goya, de todos guardo un gran recuerdo y mucho cariño, teniendo la suerte de poder disfrutar todavía de la "bisa Goya", a la que debo tanto. A mis padres Alfredo y Teresa, nunca les hizo gracia que hiciera biología, pero me apoyaron en mi elección. Por cierto, contestando a la pregunta semanal de mi madre Mama ya he entregado la tesis-, pero gracias por preocuparte por mí. A mis tíos Pilar, Carlos, Segundo y Patro, no se podría decir más literalmente que me han cuidado. A mi hermano Alfredo (sé que no siempre me entiende, pero también sé que me quiere), Silvia y mis sobrinos, Álvaro y Jimena. A mi familia política Toñi (una segunda madre) y Jordi por hacerme ser uno más de vuestra familia. En general no soy yo muy de expresar mis sentimientos, pero aprovechar no solo para daros las gracias si no deciros que os quiero.

Me gustaría dar también las gracias a mis amigos del instituto y agregados con los que tan buenos ratos he pasado (Rafa, Palomo, Nacho, Carlos, Cubillo, Jordi), mis amigos de la universidad con los que además he podido dialogar cuestiones referentes a la tesis (Ángel, Laura, Dani y Alberto) y a la gente del grupo de escalada, pues ha sido una liberación este último año poder salir al campo y volver a trepar paredes (Héctor, Jaime, Víctor, Miriam y Carlos). 
No me he olvidado de las dos personas más importantes de mi vida, simplemente quería dejarles su propio párrafo; mi mujer Diana y mi hijo Gael. No tengo palabras suficientes de agradecimiento y amor que pudieran hacer justicia a lo que siento por vosotros. Cada segundo de mi tiempo, cada palabra de esta tesis está dedicada a vosotros. Soy muy afortunado de tener a mi lado una persona como Diana, que me ha apoyado incondicionalmente; a pesar de los 400 kilómetros que hay entre Córdoba y Madrid, siempre te he sentido junto a mí y eso ha hecho que no abandonara. Gracias por todo. 


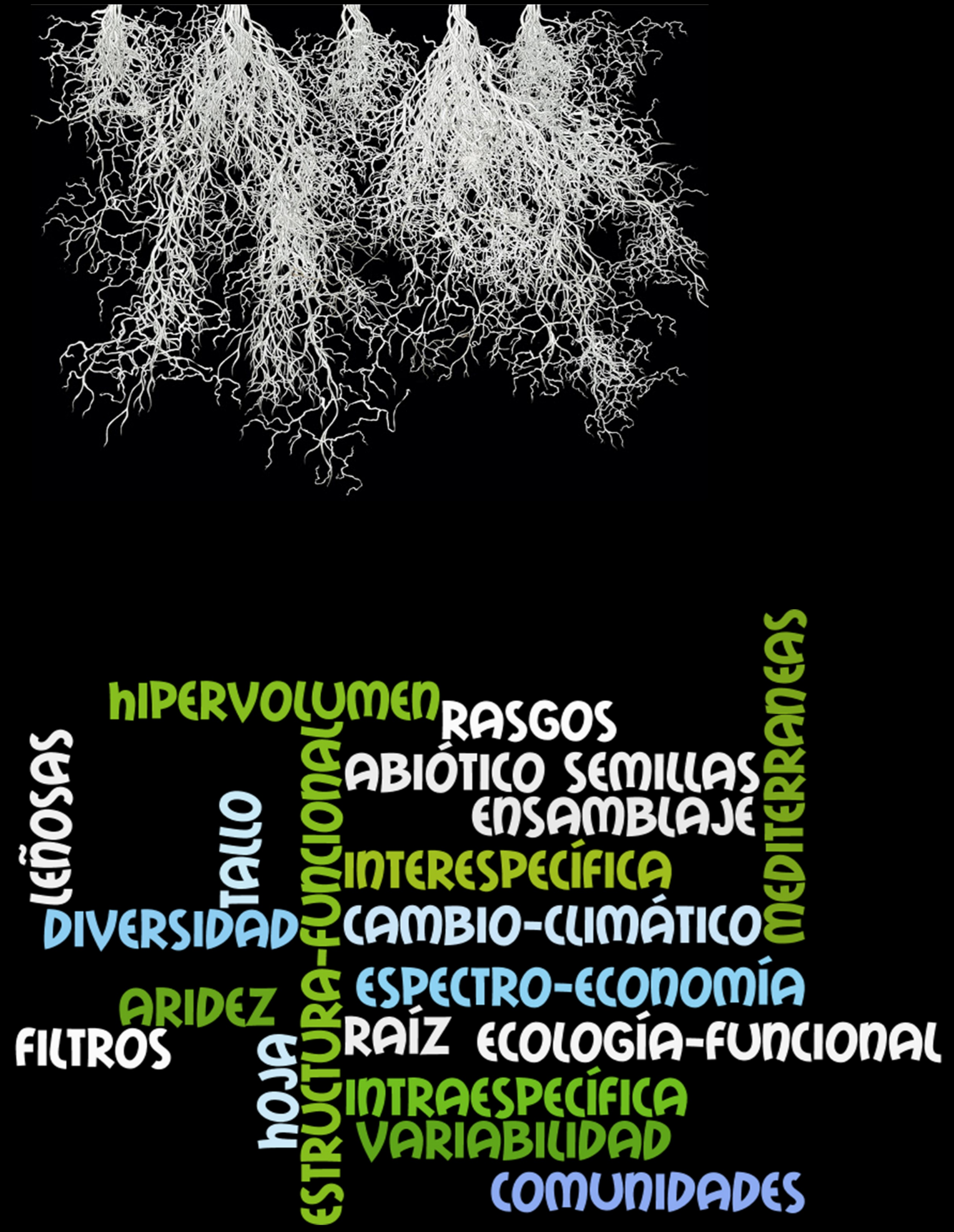

\section{CSIC}

IRNAS, CSIC, Sevilla

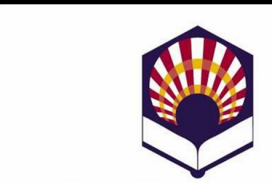

UNIVERSIDAD E CORDOBA

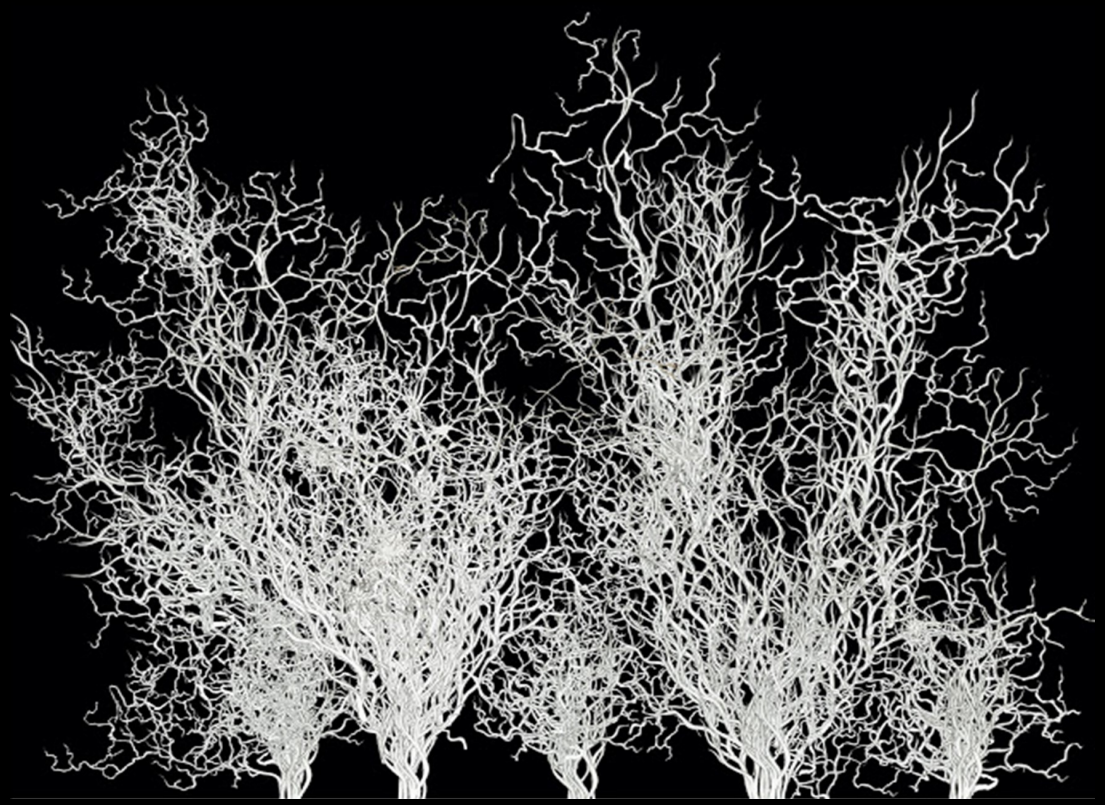

